JOSÉ EUGENIO DO AMARAL SOUZA NETO

\title{
RECURSO ORDINÁRIO CONSTITUCIONAL EM PROCESSO CIVIL
}

Dissertação apresentada à Comissão

Julgadora da Faculdade de Direito da Universidade de São Paulo, como exigência parcial para obtenção do título de Mestre em Direito Processual, sob a orientação do Professor Doutor Walter Piva Rodrigues.

Universidade de São Paulo

Faculdade de Direito

São Paulo, 2013 
Banca Examinadora 
Aos meus pais,

Maria Leticia e Paulo, por tudo, sempre. 


\section{AGRADECIMENTOS}

São muitos os agradecimentos e os agradecidos, porque a elaboração desta dissertação foi um esforço coletivo, de todos aqueles que me apoiaram durante esses três anos e tanto de mestrado.

Em primeiro lugar, como não poderia deixar de ser, aos meus queridos pais, Maria Leticia e Paulo. Mãe, obrigado por servir de exemplo profissional e moral durante toda a minha vida, por sempre me dar carinho, amor, compreensão e limites, estes últimos tão importantes para formar a minha personalidade hoje. Pai, obrigado por ter aberto as portas do mundo jurídico para nossa família, por sempre me incentivar a querer mais, me esforçar mais, batalhar mais e por ser um apoio inabalável para mim.

Agradeço ao meu irmão André, pela paciência em ceder o espaço e o tempo para que esse trabalho fosse concluído, sem nunca reclamar, e por ser o meu amigo da vida toda.

Meus avós Lya e José Eugenio, tão amados por todos, a vocês eu agradeço pelo constante interesse e apoio, pelas boas conversas e pelos abraços apertados nas comemorações. Sem a força de vocês, terminar esta dissertação simplesmente não seria possível.

Também agradeço muito aos meus tios e tias, Ana Elisa, Anete, Fernanda, Flávio, José Estanislau, Laís, Luciana, Maísa e Rodrigo, e aos meus primos, Pedro, João, Thiago, Luís Henrique, Paula e Júlia, por todos os momentos bons e risadas.

Um grande obrigado ao meu orientador, Professor Walter Piva Rodrigues, por ter aceitado o meu projeto de pesquisa, em primeiro lugar, e por ter sido um exemplo de dedicação e ternura durante esses anos. Um verdadeiro mestre!

Três pessoas em especial me acompanharam de perto e me ajudaram de corpo e alma durante o mestrado e, por isso e muito mais, merecem um agradecimento especial: Lia Carolina Batista (benhê!), você é um dos maiores exemplos que eu tenho na vida acadêmica, com uma inteligência e uma devoção inigualáveis, e também na vida pessoal, amiga de um caráter incrível; Danielle Carlomagno Gonçalves de Sá, minha companheira desde a graduação, sem você a pós-graduação não seria a mesma, nem a minha vida seria tão divertida; e Renato Xavier da Silveira Rosa, amigo e colega nas monitorias, o seu apoio foi fundamental para esse trabalho. 
Meus grandes amigos, que não têm qualquer contato com a pós-graduação, e, justamente por isso, foram a válvula de escape dos estudos, Adriana Pappone, Alessandra Godoy, Alexandre Scortecci de Paula, Alice Caetano, Ana Carolina Comodo, Ana Lucia Naccarato, André Iglesias Marujo, Bruno de Barros Ferreira, Bruno Miranda Antonio, Danielle Branco, Elisa D’Elboux Antunes, Fábio Lisot, Felipe Morgulis, Felipe Hotz de Macedo Cunha, Fernanda Martins, Gabriel Amon Silva, Gustavo Miranda Antonio, Henrique Balbin da Rocha, Ivan Tagliari, José Roberto de Souza Meirelles Filho, Luiza Teppet e Rafael Gruner, este trabalho também é de vocês.

Ao meu chefe e amigo, Tasso Duarte de Melo, agradeço pelo apoio, pelos conselhos, pelos livros emprestados e pelas férias concedidas, essenciais para que a dissertação fosse concluída.

Obrigado aos meus colegas de trabalho, André Lacerda, Arthur Wlassow, Gabriele Estábile, Marco Aurélio Brandão, Nathália Torres e Roseli Magalhães, pelos ouvidos e pela motivação.

Os meus professores das Arcadas, por quem tenho eterna admiração, Ada Pellegrini Grinover, Antonio Carlos Marcato, Cândido Rangel Dinamarco, Carlos Alberto Carmona, Carlos Alberto de Salles, Heitor Vitor Mendonça Sica, José Roberto dos Santos Bedaque, Oreste Nestor de Souza Laspro, Ricardo de Barros Leonel e Susana Henriques da Costa, merecem todas as honras e méritos por este trabalho, bem como os monitores que me acompanharam durante a pós-graduação, Bruno Vasconcelos Carrilho Lopes, Daniela Gabbay, Fábio Tabosa, Fernando Cais, Helena Najjar Abdo, Marco Antônio Lorencini e Marcos Montoro.

Aos meus colegas de pós-graduação, Alessandra Pignatari, André Carradita, Ana Marcato, Caio Liu Lopes, Fernanda Farina, Gabriel Herscovici Junqueira, Gabriela Kazue Silva, João Eberhart Francisco, João Francisco Naves da Fonseca, Larissa Gaspar Tunala, Larissa Verea, Marco Antonio Sabino, Marcos Lino, Maria Carolina Beraldo, Paula Ferraresi Santos, Pedro Henrique Bianqui, Pedro Henrique Sucupira, Ricardo Aprigliano, Rodolfo da Costa Manso Real Amadeo e Vilson Bertelli, agradeço por terem tornado a caminhada mais fácil.

Por fim, mas não menos importante, devo agradecer ao contribuinte paulista, que custeia a nossa Universidade e permitiu a conclusão deste mestrado e de tantos outros. 


\section{RESUMO}

Esta dissertação analisa o recurso ordinário constitucional, espécie recursal autônoma e heterogênea, em Processo Civil. Apenas dois tribunais superiores, o Supremo Tribunal Federal e o Superior Tribunal de Justiça, possuem competência para julgar esse recurso. Inicia conceituando recurso e duplo grau de jurisdição, bem como apontando as semelhanças e as diferenças entre esses dois institutos jurídicos processuais. Em seguida, define o critério de classificação dos recursos entre ordinários em sentido amplo e extraordinários em sentido amplo no ordenamento jurídico brasileiro, para apontar em qual categoria se enquadra o recurso ordinário constitucional. Verifica a origem histórica do recurso ordinário constitucional, com enfoque na sua disciplina pelas Constituições Federais do Brasil republicano, para que identifique quais são os motivos pelos quais essa espécie recursal existe e deve ou não ser mantida atualmente. Define cada uma das hipóteses de cabimento do recurso ordinário constitucional, priorizando a definição daquelas interessantes para o Processo Civil. Delineia os aspectos procedimentais desse recurso (requisitos de admissibilidade, efeitos devolutivo e suspensivo, procedimento perante o juízo a quo e perante o juízo ad quem, possibilidade da sua interposição adesiva e cabimento de embargos infringentes e de embargos de divergência). Aponta as funções dos tribunais superiores brasileiros, comparando-as com as funções e com os recursos de competência de Cortes Constitucionais e de tribunais superiores estrangeiros. Conclui pela necessidade de manutenção do recurso ordinário constitucional no ordenamento jurídico brasileiro, com algumas alterações das hipóteses de cabimento.

Palavras-chave: recurso ordinário constitucional; duplo grau de jurisdição; recursos ordinários; tribunais superiores; ações constitucionais; causas internacionais. 


\begin{abstract}
This dissertation analyses the recurso ordinário constitucional, a heterogenic and autonomous kind of appeal, in its Civil Procedure forms. Only two superior courts, the Supremo Tribunal Federal (the Brazilian Supreme Court) and the Superior Tribunal de Justiça (the Brazilian Federal Court of Appeals) can judge that kind of appeal. It starts conceptualizing what is an appeal and what is a two-tier judicial exam, as well as their resemblances and differences. It follows defining the standard on how to classify the appeals between ordinary and extraordinary in the Brazilian law, so the recurso ordinário constitucional can be appointed to a category. It verifies the historical origin of that kind of appeal, with special focus on its constitutional discipline, since Brazil has being a republic, so it is possible to identify the reasons why that kind of appeal exists and should or should not be maintained nowadays. It defines each one of the cases that the recurso ordinário constitucional can be interposed, prioritizing the ones regarding Civil Procedure. It outlines the procedural aspects of that kind of appeal (its admissibility requirements, its staying and non-staying effects, its procedure before the judex a quo and the judex ad quem, the possibility of that kind of appeal being adhesive, and the acceptance of the embargos infringentes and the embargos de divergência, two different kinds of appeal). It points out the scopes of the Brazilian superior courts, comparing them to the scopes and the appeals judged by foreign Constitutional Courts and superior courts. It concludes that the recurso ordinário constitucional should remain on the Brazilian law, with some modifications regarding the cases it can be interposed.
\end{abstract}

Key-words: recurso ordinário constitucional appeal; two-tier judicial exam; ordinary appeal; superior courts; constitutional writs; international suits. 


\section{SUMÁRIO}

1 INTRODUÇÃO

p. 10

2 DUPLO GRAU DE JURISDIÇÃO E RECURSO

p. 15

2.1 Conceito de duplo grau de jurisdição

p. 15

2.1.1 Vantagens do duplo grau de jurisdição

p. 18

2.1.2 Desvantagens do duplo grau de jurisdição

p. 23

2.2 Duplo grau de jurisdição: natureza constitucional?

p. 26

2.3 Duplo grau de jurisdição: regra, princípio ou garantia constitucional?

p. 30

2.3.1 Duplo grau de jurisdição como regra

p. 33

2.3.2 Duplo grau de jurisdição como princípio

p. 34

2.3.3 Duplo grau de jurisdição como garantia

p. 35

2.4 Conceito de recurso no direito brasileiro

p. 37

2.5 Diferença entre duplo grau de jurisdição e recurso

p. 38

\section{CLASSIFICAÇÃO DOS RECURSOS EM ORDINÁRIOS E}

EXTRAORDINÁRIOS - BREVE ANÁLISE CRÍTICA

p. 39

\section{RECURSO ORDINÁRIO CONSTITUCIONAL - EVOLUÇÃO HISTÓRICA}

p. 48

4.1 Tutela de direitos fundamentais - Previsão constitucional

p. 48

4.2 Evolução do tratamento constitucional

p. 50

4.3 Legislação infraconstitucional

p. 53

\section{RECURSO ORDINÁRIO CONSTITUCIONAL -} HIPÓTESES DE CABIMENTO

p. 59

5.1 Ações constitucionais

p. 61

5.1.1 Habeas corpus

p. 66

5.1.2 Mandado de segurança

p. 67

5.1.3 Habeas data e mandado de injunção

p. 68

5.2 Causas internacionais

p. 69

5.3 Crime político

p. 70 


\section{RECURSO ORDINÁRIO CONSTITUCIONAL -}

$\begin{array}{ll}\text { ASPECTOS PROCEDIMENTAIS } & \text { p. } 72\end{array}$

$\begin{array}{ll}6.1 \text { Requisitos de admissibilidade } & \text { p. } 72\end{array}$

$\begin{array}{ll}\text { 6.1.1 Subjetivos } & \text { p. } 73\end{array}$

6.1.2 Objetivos p. 74

$\begin{array}{ll}6.2 \text { Efeito devolutivo } & \text { p. } 76\end{array}$

6.2.1 Aplicabilidade do artigo $515, \S 3^{\circ}$, do CPC p. 78

$\begin{array}{ll}6.3 \text { Efeito suspensivo } & \text { p. } 80\end{array}$

$\begin{array}{ll}6.4 \text { Procedimento perante o juízo a quo } & \text { p. } 83\end{array}$

6.4.1 Duplo exame de admissibilidade p. 84

6.4.2 Interposição perante o juízo a quo - Órgão competente p. 84

6.4.3 Recurso cabível contra decisão do juízo a quo que nega

$\begin{array}{ll}\text { seguimento ao recurso ordinário constitucional p. } 86 & \text { p }\end{array}$

$\begin{array}{ll}\text { 6.5 Procedimento perante o juízo ad quem } & \text { p. } 89\end{array}$

6.6 Interposição da forma adesiva $\quad$ p. 91

$\begin{array}{ll}\text { 6.7 Cabimento de embargos infringentes } & \text { p. } 92\end{array}$

$\begin{array}{ll}\text { 6.8 Cabimento de embargos de divergência } & \text { p. } 94\end{array}$

\section{ANÁLISE CRÍTICA DO RECURSO ORDINÁRIO}

$\begin{array}{ll}\text { CONSTITUCIONAL p. } 98 & \text { p }\end{array}$

7.1 Funções dos tribunais superiores brasileiros -

$\begin{array}{ll}\text { Supremo Tribunal Federal e Superior Tribunal de Justiça } & \text { p. } 98\end{array}$

7.2 Direito estrangeiro p. 103

$7.3 \mathrm{O}$ futuro do recurso ordinário constitucional p. 115

7.3.1 Ações constitucionais p. 115

$\begin{array}{ll}\text { 7.3.2 Causas internacionais } & \text { p. } 122\end{array}$

$\begin{array}{ll}\text { 7.3.3 Crime político } & \text { p. } 124\end{array}$

8 CONCLUSÃOO p. 126

$\begin{array}{ll}\text { REFERENCIAS } & \text { p. } 136\end{array}$ 


\section{INTRODUÇÃO}

Nesta dissertação será objeto de exame o recurso ordinário constitucional, notadamente no que se refere à sua aplicação no âmbito do Processo Civil, espécie recursal autônoma regida pelos artigos 102, II e alíneas, e 105, II e alíneas, da Constituição Federal e pelos artigos 539 e 540 do Código de Processo Civil.

Não será analisado o recurso ordinário previsto na Consolidação das Leis do Trabalho (artigos 893, III, e 895 e seguintes), mas sim o recurso ordinário constitucional, espécie recursal absolutamente distinta.

O julgamento do recurso ordinário constitucional é de competência do Supremo Tribunal Federal ou do Superior Tribunal de Justiça, dependendo do caso. Isso revela a sua grande importância dentro do nosso sistema recursal, pois é um dos poucos recursos previstos constitucionalmente e é sempre julgado por tribunal superior ${ }^{1}$.

\footnotetext{
${ }^{1}$ Percentualmente, o número de recursos ordinários constitucionais não é grande, fato que não diminui a sua relevância no ordenamento jurídico. Entre 2008 e 2012, representou menos de 1\% dos processos julgados pelo Supremo Tribunal Federal e aproximadamente $2 \%$ dos processos julgados pelo Superior Tribunal de Justiça. O Supremo Tribunal Federal julgou: (i) em 2012, no total 61.380 (sessenta e um mil trezentos e oitenta) processos, sendo 351 (trezentos e cinquenta e um) recursos ordinários constitucionais - 216 (duzentos e dezesseis) interpostos em habeas corpus, 135 (cento e trinta e cinco) em mandados de segurança e nenhum em mandado de injunção ou habeas data -, o que equivale a 0,6\% (zero vírgula seis por cento) do total; (ii) em 2011 são informadas duas quantidades de processos distintas: (ii.a) na primeira coluna, julgou-se no total 64.018 (sessenta e quatro mil e dezoito) processos, sendo 420 (quatrocentos e vinte) recursos ordinários constitucionais - 261 (duzentos e sessenta e um) interpostos em habeas corpus, 159 (cento e cinquenta e nove) em mandados de segurança e nenhum em mandado de injunção ou habeas data -, o que equivale a $0,6 \%$ (zero vírgula seis por cento) do total; (ii.b) na segunda coluna, julgou-se no total 71.663 (setenta e um mil seiscentos e sessenta e três) processos, sendo 282 (duzentos e oitenta e dois) recursos ordinários constitucionais - 195 (cento e noventa e cinco) interpostos em habeas corpus, 86 (oitenta e seis) em mandados de segurança, 01 (um) em mandado de injunção e nenhum em habeas data -, o que equivale a $0,4 \%$ (zero vírgula quatro por cento) do total; (iii) em 2010, no total 60.528 (sessenta mil quinhentos e vinte e oito) processos, sendo 246 (duzentos e quarenta e seis) recursos ordinários constitucionais - 130 (cento e trinta) interpostos em habeas corpus, 116 (cento e dezesseis) em mandados de segurança e nenhum em mandado de injunção ou habeas data -, o que equivale a $0,4 \%$ (zero vírgula quatro por cento) do total; (iv) não constam dados de 2009; e (v) em 2008, no total 73.126 (setenta e três mil cento e vinte e seis) processos, sendo 216 (duzentos e dezesseis) recursos ordinários constitucionais - 115 (cento e quinze) interpostos em habeas corpus, 100 (cem) em mandados de segurança, 01 (um) em mandado de injunção e nenhum em habeas data -, o que equivale a 0,3\% (zero vírgula três por cento) do total. (Disponível em: <http://www.stf.jus.br/portal/cms/verTexto.asp?servico=estatistica\&pagina=pesquisaClasse $>$. Acesso em: 09 fev. 2013).

O Superior Tribunal de Justiça, por sua vez, julgou: (i) em 2012, no total 289.524 (duzentos e oitenta e nove mil quinhentos e vinte e quatro) processos, sendo 6.335 (seis mil trezentos e trinta e cinco) recursos ordinários constitucionais - 3.124 (três mil cento e vinte e quatro) em habeas corpus, 3.200 (três mil e duzentos) em mandados de segurança e 11 (onze) em causas internacionais -, o que representa 2,2\% (dois vírgula dois por cento) do total; (ii) em 2011, no total 290.901 (duzentos e noventa mil novecentos e um) processos, sendo 5.705 (cinco mil setecentos e cinco) recursos ordinários constitucionais - 2.325 (dois mil trezentos e vinte e cinco) em habeas corpus, 3.365 (três mil trezentos e sessenta e cinco) em mandados de segurança e 13 (treze) em causas internacionais -, o que representa 2\% (dois por cento) do total; (iii) em 2010, no total 228.981 (duzentos e vinte e oito mil novecentos e oitenta e um) processos, sendo 4.245 (quatro mil duzentos e quarenta e cinco) recursos ordinários constitucionais - 2.033 (dois mil e trinta e três) em habeas corpus, 2.204 (dois mil duzentos e quatro) em mandados de segurança e 08 (oito) em causas internacionais -, o que representa 1,9\% (um vírgula nove por
} 
Porém, esse tipo de recurso apresenta uma denominação bastante ambígua, pois designa ao mesmo tempo uma espécie - que é formada por diversas outras subespécies recursais - e um gênero, que é o dos recursos ordinários, em oposição aos extraordinários ${ }^{2}$.

Ademais, o recurso ordinário constitucional é muito pouco estudado pelos processualistas $^{3}$, o que contribui para que ele não tenha disciplina legislativa completa ${ }^{4}$, que regule todos os seus aspectos, como ocorre com os demais recursos de competência dos tribunais superiores - Supremo Tribunal Federal e Superior Tribunal de Justiça, mais especificamente -, e com os recursos ordinários em sentido amplo com os quais mais se assemelha: a apelação e o agravo.

Entretanto, ele é espécie recursal dotada de autonomia. O artigo 496 do Código de Processo Civil separa o recurso ordinário constitucional (inciso V) das demais espécies recursais - apelação (inciso I), agravo (inciso II), recurso especial (inciso VI) e recurso extraordinário (inciso VII), por exemplo -, o que revela o desejo do legislador de dotar de autonomia esse recurso ${ }^{5}$.

Daí a escolha do tema. É importante aprofundar o estudo do recurso ordinário constitucional como espécie recursal autônoma, para que se possa diferencia-la dos demais recursos que integram o gênero ordinário, permitindo ao jurisdicionado a utilização da boa técnica processual nas causas em que o recurso ordinário constitucional é cabível - ações constitucionais, causas internacionais e processos que tratem de crime político.

Não se pode desprezar a intenção do legislador e simplesmente equiparar o recurso ordinário constitucional à apelação e ao agravo, pois, conforme será analisado nesta dissertação, estes recursos apresentam diferentes hipóteses de cabimento e diferenças procedimentais, o que confirma essa autonomia.

Além disso, o recurso ordinário constitucional tem a natureza, nas ações constitucionais - subespécie com o maior número de hipóteses de cabimento do recurso e em

cento) do total; (iv) em 2009, no total 292.103 (duzentos e noventa e dois mil cento e três) processos, sendo 4.846 (quatro mil oitocentos e quarenta e seis) recursos ordinários constitucionais - 2.213 (dois mil duzentos e treze) em habeas corpus, 2.614 (dois mil seiscentos e catorze) em mandados de segurança e 19 (dezenove) em causas internacionais -, o que representa 1,7\% (um vírgula sete por cento) do total; e (v) em 2008, no total 271.521 (duzentos e setenta e um mil quinhentos e vinte e um) processos, sendo 4.843 (quatro mil oitocentos e quarenta e três) recursos ordinários constitucionais - 2.347 (dois mil trezentos e quarenta e sete) em habeas corpus, 2.477 (dois mil quatrocentos e setenta e sete) em mandados de segurança e 19 (dezenove) em causas internacionais -, o que representa $1,8 \%$ (um vírgula oito por cento) do total. (Disponível em: $<$ http://www.stj.jus.br/webstj/Processo/Boletim/?vPortalAreaPai=183\&vPortalArea=584>. Acesso em: 09 fev. 2013).

${ }^{2}$ AMORIM, 2005, pp. 193/194.

${ }^{3}$ MENDONÇA LIMA, 1958, p. 56.

${ }^{4}$ ASSIS, 2011, p. 657.

${ }^{5}$ ASSIS, 2008, p. 74; BARBI, 1991, pp. 226/227; e SOUZA, 2007, p. 48. 
que ele é interposto em maior quantidade ${ }^{6}$-, de proteção ao cidadão, posto que só é cabível contra decisão denegatória do writ $^{7}$.

Essa proteção não viola a igualdade, mas sim efetiva a isonomia ${ }^{8}$, a igualdade em seu sentido material, pois dá maior benefício ao cidadão, parte mais fraca na relação jurídicoprocessual, mais instrumentos para evitar um abuso cometido pelo poder público. $\mathrm{O}$ aprofundamento da análise desse instrumento específico, o recurso ordinário constitucional, torna-se ainda mais relevante por esse motivo.

Tanto é assim que o constituinte entendeu ser necessário prever o cabimento desse recurso no próprio texto constitucional, o que faz com que, neste caso específico, a recorribilidade ordinária seja não apenas um princípio, mas uma verdadeira garantia constitucional 9 .

Para que esse recurso específico seja abolido do ordenamento jurídico pátrio, ou mesmo modificado, seria necessária uma reforma constitucional, o que não é preciso para os demais recursos do gênero ordinário ${ }^{10}$. Daí a natureza de garantia constitucional intimamente ligada a outras garantias constitucionais, no que se refere aos writs - do duplo grau de jurisdição neste caso, e não somente de simples princípio.

Ora, dizer que um recurso previsto na Carta da República, com a finalidade tão nobre de garantir ao cidadão o duplo grau de jurisdição em certos casos em que direitos tutelados por ações constitucionais foram denegados; ou de permitir o reexame irrestrito, pelos tribunais superiores, de causas específicas - causas internacionais e que versem sobre crime político -; não se separa de outras espécies recursais ${ }^{11}$ não é correto.

\footnotetext{
${ }^{6}$ Vide nota 01.

${ }^{7}$ AMORIM, 2005, p. 197; BARBOSA, 1990, p. 61; DIDIER JR. e CUNHA, 2010, p. 246; e SIQUEIRA, 2001, p. 34.

8 "A isonomia deve, pois ser entendida substancialmente. Todos devem ter as mesmas chances de atingir o conteúdo da norma, a finalidade a que se presta, ainda que por caminhos - formas - diferentes. No plano do direito material, significa que todos devem ter a possibilidade de ser titulares dos direitos que o ordenamento jurídico lhes confere e de efetivamente exercê-los. No plano processual, o acesso à Justiça e a possibilidade de litigar em igualdade de condições se impõe. Todos devem poder exercer, substancialmente, todo o conjunto de direitos e faculdades que a lei processual assegura aos litigantes.” (MARCACINI, 1996, p. 10).

9 DINAMARCO, 1995, p. 189; MENDONÇA, 2006, p. 600; NERY JÚNIOR, 2004, p. 48; THEODORO JÚNIOR, 1993, p. 08.

${ }_{10}^{10}$ ASSIS, 2008, p. 73.

${ }^{11}$ Como faz Pontes de MiRAnda (1975, pp. 04/05), em Comentários ao Código de Processo Civil atual, escritas na vigência da Constituição de 1967, já modificada pela EC n 01/69: "A interpretação do art. 119, II, da Constituição de 1967, com a Emenda n. 1, como a do art. 101, II, da Constituição de 1946, que desse nome especial (e pois conceito especial) ao recurso que o Supremo Tribunal Federal tem de lugar em virtude da sua competência recursal, foi e seria errada. O que acontecera a alguns juristas de modo nenhum poderia prevalecer. A Constituição de 1967, com a Emenda n. 1, como a de 1946, apenas alude a competência para julgar qualquer recurso que possa ser interposto de decisão e caiba ao Supremo Tribunal Federal dele conhecer e julgá-lo. Qualquer recurso que caiba. Falar-se de 'recurso ordinário constitucional' seria absurdo. Os recursos ordinários
} 
O que falta para que não se possa pôr em questão a autonomia do recurso ordinário constitucional é uma melhor tutela legislativa do instituto, pelo menos no que se refere ao Processo Civil. Como se verá ao longo deste trabalho, deixou-se a um único artigo do Código de Processo Civil, o artigo 540, e aos Regimentos Internos do Supremo Tribunal Federal e do Superior Tribunal de Justiça a tarefa de regular o recurso.

Esse "desprestígio legislativo" do recurso ordinário constitucional acaba por impedir a sua boa aplicação na prática, já que muitas vezes o operador do direito deve se valer da doutrina, não raro divergente, para que possa lidar na prática com esse tipo de recurso.

A doutrina deve cumprir o seu papel e contribuir na formação dos contornos do recurso ordinário constitucional, esclarecendo qual deve ser a melhor regulamentação dessa espécie recursal e, assim, inspirar o legislador a editar normas que o possam regular. É, aliás, com o que se espera que esta dissertação possa contribuir.

Antes de partir para o estudo do recurso ordinário constitucional, é prudente analisar de forma mais detida dois institutos jurídicos umbilicalmente ligados a ele: o duplo grau de jurisdição e o próprio conceito de recurso.

Ainda há bastante controvérsia doutrinária sobre a natureza jurídica do duplo grau de jurisdição, apesar do seu conceito ser bastante claro - não obstante a expressão "duplo grau de jurisdição" ser reputada equívoca por parte da doutrina. Delimitar o alcance do duplo grau de jurisdição, bem como situá-lo no ordenamento jurídico pátrio, é essencial para que se entenda o real papel do recurso ordinário constitucional, espécie de recurso que efetiva o duplo grau de jurisdição.

Da mesma maneira, identificar claramente o que é recurso, que muitas vezes é confundido com o já citado duplo grau de jurisdição, é o ponto de partida ideal para o estudo do recurso ordinário constitucional.

Em seguida, faz-se o exame comparativo entre os recursos ordinários em sentido amplo, entre eles a espécie recursal ora estudada, e os recursos extraordinários em sentido amplo, justamente para conceituar o recurso ordinário constitucional no sistema recursal brasileiro. A distinção entre o gênero recursal ordinário e o extraordinário levará em conta o prisma estrangeiro e o nacional, delimitando quais os critérios adotados pela doutrina brasileira para separar um do outro - e qual o critério que se considera correto - e quais as características próprias de cada um.

tocam ao corpo julgador de grau superior, e espécies há em que tal corpo julgador tem de ser o Supremo Tribunal Federal.”. 
Na sequência, será estudada a origem histórica do recurso ordinário constitucional, com foco na sua disciplina pelas Constituições Federais do Brasil republicano, para que se entendam as razões da sua previsão no nosso sistema recursal e de tutelar apenas alguns casos específicos, tanto pela natureza da decisão recorrida, quanto pela importância conferida pelo constituinte à causa levada a juízo.

Feita essa digressão histórica, passar-se-á para a classificação de cada uma das hipóteses de cabimento do recurso ordinário constitucional. Definido o critério adotado para a divisão da espécie recursal em subespécies, serão apontadas as peculiaridades de cada uma, com especial atenção àquelas pertinentes ao Direito Processual Civil. Como o recurso ordinário constitucional tem cabimento tanto no âmbito do Processo Civil como no do Processo Penal, delimitou-se a matéria estudada apenas ao âmbito do Processo Civil, porém não se pode deixar de mencionar, ainda que brevemente, as hipóteses de cabimento desse recurso no Processo Penal.

Fixadas as premissas históricas e os principais contornos do recurso ordinário constitucional, seguir-se-á com a análise detida de seus aspectos procedimentais. Serão objeto de estudo os requisitos de admissibilidade do recurso ordinário constitucional; seus efeitos devolutivo e suspensivo; o seu procedimento, tanto perante o juízo a quo, quanto perante o juízo ad quem; a possibilidade da sua interposição adesiva; e o cabimento de embargos infringentes e de embargos de divergência em sede de recurso ordinário constitucional. Não se analisará o procedimento aplicável ao recurso ordinário constitucional previsto no Projeto de Novo Código de Processo de Processo Civil, atualmente em trâmite no Congresso Nacional, porque o texto da lei já sofreu diversas alterações, podendo haver mais mudança em um curto espaço de tempo, o que poderá fazer com que esse exame perca sua valia.

Por fim, o exame crítico do recurso ordinário constitucional, por meio do estudo das funções dos tribunais superiores, notadamente o Supremo Tribunal Federal e o Superior Tribunal de Justiça, e das razões pelas quais têm competência originária e recursal ordinária em determinados casos; e da análise das funções e dos recursos de competência das Cortes Constitucionais e dos tribunais superiores europeus - francês, italiano, espanhol e português e latino-americanos - argentino e uruguaio. Pretende-se concluir pela necessidade de exclusão ou manutenção do recurso ordinário constitucional no ordenamento jurídico brasileiro e, se mantido, se é devida a redução ou o aumento das suas hipóteses de cabimento.

Espera-se que esta dissertação possa enriquecer o debate em relação ao recurso ordinário constitucional e ajudar na definição dessa espécie recursal, tão importante e, ao mesmo tempo, tão esquecida. 


\section{DUPLO GRAU DE JURISDIÇÃO E RECURSO}

Neste capítulo serão conceituados o duplo grau de jurisdição e o recurso, apontando-se suas semelhanças e diferenças. Esses dois institutos jurídicos têm estreita ligação com o objeto de estudo deste trabalho, o recurso ordinário constitucional. Essa é uma das espécies de recurso que efetiva o duplo grau de jurisdição, e, para se compreender essa afirmação, é necessário delinear o que se entende ser recurso e o que se entende ser duplo grau de jurisdição.

\subsection{Conceito de duplo grau de jurisdição}

O conceito de duplo grau de jurisdição não está positivado no ordenamento jurídico brasileiro, ou mesmo em qualquer outro ordenamento jurídico que se tenha notícia, tendo sido desenvolvido pela doutrina e pela jurisprudência ${ }^{12}$.

Sendo um conceito predominantemente doutrinário, diferentes autores o definiram de diferentes maneiras.

Duas das mais precisas definições de duplo grau de jurisdição foram feitas por ORESTE Nestor de Souza Laspro $(1995)^{13}$ e por Ana CÂndida Menezes MarCato (2006) ${ }^{14}$, em suas respectivas dissertações de mestrado apresentadas a esta faculdade.

Esses conceitos não são coincidentes, mas é possível extrair deles e de outros conceitos os seguintes traços comuns do duplo grau de jurisdição:

(i) o duplo grau de jurisdição deve possibilitar ${ }^{15}$ a reanálise plena, total, completa do mérito da causa ${ }^{16}$. Ou seja, já proferida uma decisão final sobre a causa, é necessário que seja possível que toda a causa seja reapreciada para que se configure o duplo grau de jurisdição;

(ii) essa devolução integral também deve se dar no mesmo processo ${ }^{17}$, não dando ensejo à propositura de uma nova ação para que se proceda ao reexame da causa ${ }^{18}$;

\footnotetext{
${ }^{12}$ LASPRO, 1995, p. 17.

13 "Apresentados os aspectos, positivo e negativo, do sistema do duplo grau, bem como as características das decisões judiciais que o compõe, podemos, finalmente conceituar o duplo grau de jurisdição como sendo aquele sistema jurídico em que, para cada demanda, existe a possibilidade de duas decisões válidas e completas no mesmo processo, emanadas por juízes diferentes, prevalecendo sempre a segunda em relação à primeira." (Idem, p. 27, grifos nossos).

14 "Dessa forma, tendo em mente os elementos mencionados e as posições doutrinárias encontradas, optamos por adotar o seguinte conceito de duplo grau de jurisdição: possibilidade de reapreciação do mérito da causa, por meio do reexame da decisão final de instância original, abrangendo tanto as questões de fato como as de direito, por órgão jurisdicional diverso, sendo este de hierarquia superior ou não." (MARCATO, 2006, p. 24, grifos nossos).

${ }^{15}$ COMOGLIO, 1999 , p. 328

${ }^{16}$ TEIXEIRA, 2008, p. 342.
} 
(iii) o juízo que realizar o duplo grau de jurisdição deve ser diverso do juízo que primeiro julgou a causa; e

(iv) o segundo julgamento sempre prevalece sobre o primeiro.

Os autores acima citados divergem apenas em um ponto: a necessidade de que as duas decisões sejam válidas. Oreste NeStOR DE SOUZA LASPRo exige que as duas decisões sobre o mérito da causa sejam válidas para que se caracterize o duplo grau de jurisdição, enquanto ANA CÂNDIDA MENEZES MARCATO considera que esse requisito não é necessário.

Respeitada a primeira posição, concorda-se com a segunda.

Para que haja duplo grau de jurisdição não é necessário que as duas decisões sejam válidas ou que tenham ambas enfrentado o mérito da causa, é preciso apenas que as duas tenham a possibilidade de analisá-lo, sendo que a segunda sempre prevalecerá sobre a primeira ${ }^{19}$. Nesse sentido, o artigo 515, $\S 3^{\circ}$, do Código de Processo Civil, ao dispor que extinto o processo sem resolução do mérito, versando a causa apenas sobre questões de direito e estando o processo em condições de julgamento, o juízo ad quem deve julgar a lide desde $\operatorname{logo}$, não viola o duplo grau de jurisdição ${ }^{20}$.

Isso porque, conforme exposto acima, o duplo grau de jurisdição não significa a necessidade de um duplo julgamento de mérito, mas sim a possibilidade de que ele tenha sido realizado. Quando aplicada a teoria da causa madura, positivada pelo referido dispositivo legal, o juízo a quo poderia ter proferido sentença de mérito, mas não o fez, sendo possível que o mérito da causa seja apreciado desde logo pelo juízo ad quem, sem a necessidade de prolação de nova sentença pelo juízo a quo.

Ou seja, nesse caso era possível que duas decisões definitivas, a sentença e o acórdão que julga a apelação, proferidas no mesmo processo, tivessem apreciado por inteiro o mérito da causa, prevalecendo a segunda decisão, prolatada por juízo diverso do primeiro, o que caracteriza o duplo grau de jurisdição.

\footnotetext{
${ }^{17}$ TAVARES, 2000, p. 184.

${ }^{18}$ Em tese, seria possível a criação de uma ação, de competência originária dos tribunais, que visaria a impugnar as sentenças de primeiro grau, com ampla cognição e livre motivação, o que cumpriria os mesmos propósitos do duplo grau de jurisdição. Porém, isso subverteria toda a lógica do sistema processual vigente, alterando fundamentalmente o conceito de coisa julgada e as formas de impugná-la, conforme será melhor analisado a seguir, no item 2.1.1 desta dissertação.

19 “'- in ogni caso, l'esigenza del 'doppio giudizio' degrada ad una eventualità, poiché alle parti si vuole garantire non tanto la possibilità di ottenere efetivamente uma doppia ed integrale cognizione dela medesima controversia in due diversi giudizi, quanto piuttosto la possibilità di sottopore, in tutto o in parte, il rapporto in lite alla cognizione di due diversi giudici." (COMOGLIO, 1999, p. 329).

${ }^{20}$ A posição defendida é minoritária. Encontra respaldo em FRANCO, 2008, p. 693; e LOPES, 2009, p. 174.

A maior parte da doutrina entende que referido dispositivo legal é constitucional, pois prestigia outros princípios processuais, o da economia processual e o da duração razoável do processo, em detrimento do duplo grau de jurisdição, mas entendem os doutrinadores que ele é mitigado neste caso (ELIAS, 2011, pp. 88/89; LEONEL, 2007, p. 203; LUCON, 2008, p. 38; MELO, 2005, pp. 681/682; e VAZ, 2006, p. 89).
} 
Definido o conteúdo do instituto jurídico do duplo grau de jurisdição, resta saber se a expressão "duplo grau de jurisdição" é ou não exata para transmitir o significado acima delineado, bem como quais são as vantagens e as desvantagens da adoção do duplo grau.

O termo "duplo" é o único que se amolda com perfeição ao conteúdo do instituto jurídico, porque para que haja duplo grau de jurisdição basta que dois órgãos julgadores possam examinar todo o mérito da causa no mesmo processo ${ }^{21}$.

Há controvérsia doutrinária sobre o acerto do uso da expressão "grau". Grau significa nível de órgão jurisdicional dentro da organização judiciária (primeiro, segundo, etc.), sendo por vezes substituído pela palavra instância ${ }^{22}$.

Assim, parte da doutrina entende que, para existir duplo grau de jurisdição, é necessário que dois órgãos de diferentes níveis hierárquicos - um superior ou outro - realizem os dois julgamentos ${ }^{23}$.

A corrente majoritária, por outro lado, afasta a necessidade de que os exames sejam feitos por juízos de diferentes patamares hierárquicos, considerando que há duplo grau de jurisdição mesmo quando o órgão julgador responsável pela revisão completa da decisão sobre a causa seja de mesmo nível que aquele que proferiu a decisão reexaminada ${ }^{24}$.

De fato, melhor considerar que o duplo grau de jurisdição se efetiva quando um segundo órgão julgador pode reapreciar por completo o mérito da causa, seja este órgão de maior hierarquia do que aquele que primeiro examinou a causa ou não. Exigir juízos de diferentes níveis é prender-se demais à expressão "duplo grau de jurisdição", cunhada, como já se disse, pela doutrina e pela jurisprudência, sem levar em conta o seu verdadeiro objetivo.

Por fim, o termo "jurisdição" é empregado sem rigor técnico. Jurisdição é "uma das funções do Estado, mediante a qual este se substitui aos titulares dos interesses em conflito para, imparcialmente, buscar a pacificação do conflito que os envolve, com justiça" 25 .

Não existem duas jurisdições ${ }^{26}$. A jurisdição é una. O que acontece, por meio do duplo grau, é o possível reexame completo da causa por um segundo juízo, não por outra jurisdição.

\footnotetext{
${ }^{21}$ LASPRO, 1999, p. 192.

${ }^{22}$ DINAMARCO, 2009b, pp. 162/163.

23 AMARAL SANTOS, 2010, p. 85; CANOTILHO, 2001, pp. 660/661; CHEIM JORGE, 2011, p. 227; CINTRA, GRINOVER e DINAMARCO, 2006, p. 80; e SOUZA, 2011, p. 62.

${ }^{24}$ COMOGLIO, 1999, p. 328; LASPRO, 1995, p. 19; MARCATO, 2006, p. 27; MARINONI e ARENHART, 2011, p. 487; OLIVEIRA, 2008, p. 363; TAVARES, 2000, p. 178; e TEIXEIRA, 2008, p. 339.

${ }^{25}$ CINTRA, GRINOVER e DINAMARCO, 2006, p. 145.

26 "Primeiramente, é importante esclarecer que, nada obstante o nome do princípio, a sua conceituação não está relacionada com a duplicidade da jurisdição (que é una), mas sim com a possibilidade de reexame das decisões, tendo-se em conta a competência dos órgãos julgadores, para tanto. Como se sabe, a jurisdição constitui expressão do poder estatal soberano e, como tal, não comporta divisões. Em outras palavras, quando se fala em duplo grau de jurisdição não se faz referência à duplicidade da jurisdição em si mesma considerada, mas, sim, ao
} 
Não existem duas jurisdições sobre o mesmo processo, o que torna a expressão "duplo grau de jurisdição" equívoca.

Atendo-se à técnica processual, melhor seria substituir a locução "duplo grau de jurisdição" por duplo juízo de cognição.

O termo "grau" é excluído, já que não é necessário que haja diferença hierárquica entre os órgãos julgadores, mas apenas que se faça o segundo exame por órgão julgador diverso do primeiro, e a palavra "jurisdição" é suprimida, porque não existem duas jurisdições atuando neste caso. Insere-se "juízo de cognição" para apontar que há outro órgão que terá amplo conhecimento sobre a causa, podendo decidi-la pela segunda vez.

Não obstante, em razão de estar arraigado na doutrina e na jurisprudência, bem como ser de uso padrão na prática forense, a expressão “duplo grau de jurisdição” permanecerá sendo utilizada ao longo desta dissertação.

\subsubsection{Vantagens do duplo grau de jurisdição}

A doutrina apresenta diversas vantagens e desvantagens do duplo grau de jurisdição ${ }^{27}$. Tentar-se-á apontar primeiro as principais vantagens e depois as desvantagens, examinando brevemente se elas, de fato, são pontos positivos e negativos à adoção do duplo grau de jurisdição, para, por fim, concluir pela manutenção ou exclusão desse instituto do nosso ordenamento jurídico.

A primeira vantagem do duplo grau de jurisdição é satisfazer a necessidade psicológica do vencido de recorrer, ou seja, de levar novamente a sua tese a exame, por outro juízo, para verificar se este a acolherá. É intrínseco ao ser humano não se conformar, desde logo, com a derrota ${ }^{28}$. A sociedade precisa de uma "válvula de escape", de um segundo juízo que possa alterar o resultado do processo, até para pacificar de fato os conflitos ${ }^{29}$.

O duplo grau de jurisdição é a melhor forma de satisfazer o psicológico do vencido, pois pensar em uma reanálise completa da causa em um segundo processo seria acabar com a

desmembramento da competência, em dois órgãos jurisdicionais distintos, duas instância distintas, pertencentes ou não a hierarquias diversas." (MARCATO, 2006, p. 23, grifo da autora).

${ }^{27}$ Uma lista bastante completa e sintética é o índice do artigo de BECKER, 2005, p. 142.

${ }^{28}$ DINAMARCO, 2005, p. 257; e MENDONÇA LIMA, 1976, p. 127.

29 "No que diz respeito à alegada tendência evolutiva no sentido da derrogação do duplo grau, embora não haja resposta direta de Allorio, a linha de seu pensamento e a afirmação de que 'o povo não considera uma justiça nem bem organizada, nem tranquila se não contemplar a possibilidade de apelar' permite deduzir que sua ideologia converge para a concepção de um ordenamento jurídico que conflita os anseios da sociedade cujas relações deve regular, e que, considerando essa sociedade a segurança e a justiça como valores a serem respeitados pela via recursal, é impensável sua supressão.” (SÁ, 1999, p. 96). 
coisa julgada, tal qual a temos hoje, o que representaria a total reestruturação da lógica processual civil. Portanto, esta é uma das verdadeiras vantagens do duplo grau de jurisdição.

O duplo grau de jurisdição também permite uma segunda análise completa da causa, o que diminui a probabilidade de erros judiciais ${ }^{30}$, erros esses de qualquer natureza ${ }^{31}$, e tende a melhorar a interpretação e a aplicação da norma ao caso concreto.

Um segundo exame sempre reduz as chances de equívoco, seja no âmbito do Direito ou de qualquer outra ciência ou atividade ${ }^{32}$. O marceneiro que mede duas vezes a sala em que serão colocados os móveis por ele fabricados diminui a probabilidade deles ficarem muito grandes ou muito pequenos; a cozinheira que checa de novo a proporção dos ingredientes de uma receita ou o tempo de cozimento também aumenta a chance de fazer um prato mais saboroso. Não é diferente no Direito, em que levar a um segundo exame, por outra pessoa, aquilo que foi decidido por uma primeira contribui para que a decisão final seja mais precisa.

O duplo grau de jurisdição não elimina erros, tampouco garante uma segunda decisão melhor, mais completa e/ou mais justa. A justificativa de que o primeiro juiz é humano e, por isso, suscetível de cometer erros, também vale para o segundo juiz, tão humano quanto o primeiro. Mas é inquestionável que verificar duas vezes o trabalho realizado, no caso, a sentença judicial, contribui sim para reduzir a probabilidade de injustiça ${ }^{33}$.

Vale aqui a mesma anotação exposta acima: pensar em outra forma de rever toda a causa em um segundo processo, acabando com o duplo grau de jurisdição, inverte a lógica processual civil vigente e faz cair por terra todo o sistema construído durante séculos.

Outra vantagem do duplo grau de jurisdição é a maior experiência dos julgadores de segundo grau, fator que aumenta a probabilidade de que a segunda decisão seja mais justa, pois a experiência torna o trabalho mais rápido, mais preciso, aumenta a percepção de erros, diminui as influências externas do julgador.

É possível que o julgador de segundo grau seja menos experiente do que o de primeiro. Explica-se: o segundo magistrado pode ter ingressado há menos tempo na magistratura, seja porque provém do quinto constitucional, seja porque o primeiro magistrado decidiu fazer uma carreira mais lenta, ficando em uma comarca interiorana por anos. A menor experiência pode ser para uma matéria em específico: o primeiro julgador pode estar

\footnotetext{
${ }^{30}$ MENDONÇA LIMA, 1976, p. 133; e NERY JÚNIOR, 2004, p. 39.

${ }^{31}$ Entre os possíveis erros que o juiz pode cometer ao julgar, alguns decorrem da chamada parcialidade subjetiva, que não é um fato objetivo que leva ao impedimento ou à suspensão do julgador, mas sim uma convicção pessoal que faz com que analise uma determinada causa mais propenso a julgá-la em favor de uma das partes. Nesse sentido: CALMON DE PASSOS, 1982, p. 05.

${ }^{32}$ SÁ, 1999, pp. 94/95.

${ }^{33}$ OLIVEIRA, 2008, p. 366.
} 
familiarizado com direito de família, por exemplo, há anos, enquanto o segundo pode nunca ter trabalhado com essa matéria, tendo sido promovido a Desembargador após anos em uma vara de falências.

No entanto, a regra geral é a maior experiência do julgador de segundo grau, o que configura uma das vantagens do duplo grau de jurisdição.

Outra vantagem do duplo grau de jurisdição é o julgamento colegiado pelo juízo ad $q_{u e m}^{34}$. Há inclusive prestigiada doutrina que entende haver o princípio constitucional da colegialidade $^{3536}$, que decorre do duplo grau de jurisdição ${ }^{37}$ e da garantia do juiz natural ${ }^{38}$. Por esse princípio, decisão monocrática em segundo julgamento é válida desde que seja possível submetê-la ao crivo do colegiado, normalmente por meio do chamado agravo interno ou regimental $^{39}$.

O colegiado faz com que a decisão seja tomada por maioria de votos, o que efetiva ainda mais a justiça, já que se debaterá aquela causa entre mais juízes, sendo eles mais experientes. Lógico, portanto, que prevaleça o entendimento mais adequado ao caso concreto $^{40}$.

A tendência é que cada vez menos as decisões de tribunais sejam proferidas dessa forma. Em consulta ao sítio eletrônico do Supremo Tribunal Federal, verifica-se que, desde 2008, primeiro ano em que constam dados, as decisões monocráticas superam as colegiadas em proporção de aproximadamente dez para uma ${ }^{41}$.

\footnotetext{
${ }^{34}$ KOZIKOSKI, 2011, p. 144.

${ }^{35}$ BUENO, 2012, p. 163; e MELLO, 2009, pp. 460/461. JORGE, 2011, pp. 96/97; e SOUZA, 2011, p. 65. 2011; e NERY JÚNIOR, 2010. $161)$.

${ }^{37}$ Idem, p. 163.

${ }^{38}$ BUENO, 2012, p. 163; e CHEIM JORGE, 2011, pp. 96/97.

${ }^{39}$ BUENO, 2012, p. 162; MELLO, 2009, pp. 460/461; e SOUZA, 2011, pp. 65/67.
}

Também entendem que a colegialidade é princípio recursal, mas de natureza infraconstitucional, CHEIM

Não enumeram a colegialidade como princípio processual: ASSIS, 2011; DINAMARCO, 2005; KOZIKOSKI,

36 "Por 'princípio da colegialidade' deve ser entendido que a manifestação dos Tribunais brasileiros, sempre de acordo com o modelo constitucional do processo civil, deve ser plural, isto é, colegiada, no sentido de não poder ser realizada por um só de seus membros isoladamente, unitariamente, monocraticamente." (BUENO, 2012, p.

Adotando esse entendimento, o artigo 527, II e parágrafo único, do Código de Processo Civil, que permite que o relator converta, por decisão monocrática irrecorrível, o agravo de instrumento em retido seria inconstitucional, pois violaria o princípio da colegialidade, já que permitiria o julgamento singular do recurso sem a possibilidade de revisão dessa decisão pela turma julgadora.

${ }^{40}$ MARCATO, 2006, pp. 42/43.

${ }^{41}$ Em 2008, foram 109.126 (cento e nove mil cento e vinte e seis) decisões monocráticas e apenas 19.697 (dezenove mil seiscentas e noventa e sete) colegiadas; em 2009, 86.780 (oitenta e seis mil setecentas e oitenta) monocráticas e 16.079 (dezesseis mil e setenta a e nove) colegiadas; em 2010, 98.349 (noventa e oito mil trezentas e quarenta e nove) monocráticas e 11.334 (onze mil trezentas e trinta e quatro) colegiadas; em 2011, 89.305 (oitenta e nove mil trezentas e cinco) monocráticas e 13.095 (treze mil e noventa e cinco) colegiadas; e em 2012, 77.757 (setenta e sete mil setecentas e cinquenta e sete) monocráticas e 12.089 (doze mil e oitenta e nove) colegiadas. 
A legislação processual civil cada vez mais prestigia a decisão monocrática do relator (por exemplo, os artigos 557 e 527 do Código de Processo Civil), como forma de desafogar os tribunais e permitir julgamentos mais céleres. Isso elimina o colegiado e, por consequência, uma das vantagens trazidas pelo duplo grau de jurisdição ${ }^{42}$.

O fundamento político do duplo grau de jurisdição é a necessidade de controle das decisões judiciais. O Judiciário é o Poder com menor legitimidade popular, já que nenhum dos seus integrantes é eleito pelo voto direto. Exerce atividade estatal e toda atividade do Estado deve ser controlada de alguma forma, ainda que este controle seja interno ao próprio Poder $^{43}$. Daí a necessidade do duplo grau de jurisdição, que, ao permitir o amplo conhecimento da causa por um segundo órgão, reduz consideravelmente o despotismo judicial, a atuação errônea do magistrado de primeiro grau ${ }^{44}$.

Há objeção a essa alegada vantagem, pois o duplo grau teria como objetivo maior conferir possível benefício ao vencido, não controlar a atividade do Judiciário, controle esse que poderia ser feito por meio das corregedorias dos tribunais e também do Conselho Nacional de Justiça ${ }^{45}$.

No entanto, esses órgãos não têm competência para analisar as decisões judiciais, mas sim o cumprimento dos deveres funcionais dos magistrados, o que afasta essa objeção: ao mesmo tempo que o objetivo precípuo do duplo grau de jurisdição é dar possibilidade de vitória ao vencido, não se pode dizer que não há controle da atividade jurisdicional dos juízes de primeiro grau por meio desse instituto jurídico, o que é benéfico para o Judiciário e para a

\footnotetext{
Ou seja, de um total de 431.951 (quatrocentas e trinta e uma mil novecentas e cinquenta e uma) decisões, apenas 72.294 (setenta e duas mil duzentas e noventa e quatro) foram acórdãos, o que equivale a 16,3\% (dezesseis vírgula três por cento) do total. (Disponível em $<$ http://www.stf.jus.br/portal/cms/verTexto.asp?servico=estatistica\&pagina=decisoesgeral $>$. Acesso em: 04 fev. 2013).

${ }^{42}$ MARCATO, 2006, p. 49.

${ }^{43}$ CINTRA, GRINOVER e DINAMARCO, 2006, p. 81.

44 "Além dessas circunstâncias, há ainda o fato de que o juiz único poderia tornar-se despótico, sabedor de que sobre as decisões não haveria controle algum, conforme sábia advertência de Montesquieu." (NERY JÚNIOR, 2004, p. 39).

45 "Não é possivel esquecer, contudo, que a finalidade do duplo grau não é permitir o controle da atividade do juiz, mas propiciar ao vencido a revisão do julgado. Como disse há muito tempo Chiovenda, não é possível a pluralidade das instâncias fundar-se, no direito moderno, na subordinação do juiz inferior ao superior, por não dependerem os juízes, quanto à aplicação da lei, senão da lei mesma. O recurso não é mais uma 'reclamação contra o juiz inferior', 'mas o expediente para passar de um a outro o exame da causa'.

Não é correto dizer, em outras palavras, que o controle da justiça da decisão possa ser confundido com o controle da própria atividade do juiz. Não há que se falar em controle da atividade do juiz quando se está discutindo sobre a oportunidade de dar ao vencido o direito à revisão da decisão que lhe foi contrária. Lembre-se que os tribunais, através das corregedorias, têm suas próprias formas de inibir condutas ilícitas, que obviamente não se confundem com decisões 'injustas'.” (MARINONI e ARENHART, 2011, p. 488).
} 
sociedade $^{46}$, e porque as corregedorias e o Conselho Nacional de Justiça não têm competência para essa atividade.

O sistema processual vigente permite o controle das decisões judiciais por outros meios, como pela via rescisória, que contempla entre as suas hipóteses de cabimento casos em que há controle da decisão rescindenda, como os de prevaricação, de corrupção ou concussão do juiz (artigo 485, I, do CPC), de decisão proferida por juiz absolutamente incompetente (inciso II do referido artigo) ou de decisão que viola literal disposição de lei (inciso V do mesmo dispositivo legal).

Todavia, ainda que haja o controle das decisões judiciais finais por meio da ação rescisória, as hipóteses de cabimento dessa ação autônoma de impugnação são muito mais restritas que a do duplo grau de jurisdição, o que ainda o faz o instituto jurídico mais efetivo para controlar as decisões judiciais. Uma forma de controle também não retira a valia da outra, não se podendo negar que o duplo grau mantém essa como uma das suas vantagens.

Sendo assim, ainda que o duplo grau de jurisdição seja a única maneira de controlar as decisões judiciais e que esse não seja o seu principal objetivo, esse controle é uma das vantagens do instituto.

O duplo grau de jurisdição também levaria à uniformização da jurisprudência, já que apenas pela concentração do julgamento dos recursos em tribunais é que seria possível firmar a interpretação da lei, aumentando a segurança jurídica ${ }^{47}$.

Respeitada essa posição, não se concorda que esta seja uma vantagem do duplo grau de jurisdição. É plenamente possível que a pacificação da jurisprudência ocorra se o reexame da causa for limitado às questões de direito, como, aliás, já ocorre hoje com os recursos extraordinários em sentido amplo.

Dessa forma, ainda que o duplo grau de jurisdição possa firmar a interpretação da lei pelos tribunais, ele não é imprescindível para tanto, não sendo essa uma vantagem do duplo grau de jurisdição.

Por fim, a doutrina aponta a maior cautela do julgador de primeiro grau quando sabe que a sua decisão está sujeita a reexame como um ponto positivo do duplo grau de jurisdição $^{48}$.

Não se concorda com essa afirmação, pois nada a comprova. O juiz sempre deve ser cauteloso quando julga, pois o cuidado é intrínseco à atividade jurisdicional e aos integrantes

\footnotetext{
${ }^{46}$ MENDONÇA LIMA, 1976, p. 134.

${ }^{47}$ TEIXEIRA, 2008, p. 340.

${ }^{48}$ MARCATO, 2006, p. 43; e MENDONÇA LIMA, 1976, 99. 135/136.
} 
da magistratura ${ }^{49}$. Pensar que um julgador seria relapso quando sabe que o quanto decidido por ele não poderá ser alterado é desprestigiar a magistratura como instituição e os juízes como pessoas $^{50}$.

Ademais, a lógica parece ser a oposta: quando se julga em última instância tem-se maior cuidado para não cometer erros ou efetivar injustiças, justamente porque aquele julgamento é definitivo. Essa não é uma das vantagens do duplo grau de jurisdição, portanto.

\subsubsection{Desvantagens do duplo grau de jurisdição}

A primeira desvantagem apontada pela doutrina é o desprestígio do julgador de primeira instância ${ }^{51}$. Ao poder ter a sua decisão reformada e ao sempre vê-la substituída pela segunda decisão, o primeiro juiz sentiria que o seu trabalho não teria valor, o que o aborreceria.

Mesmo que isso fosse verdade, não é motivo para eliminar o duplo grau de jurisdição do ordenamento jurídico. Adotar essa premissa é o mesmo que pensar que o médico plantonista não poderia rever o diagnóstico do médico residente, porque este se sentiria desprestigiado, sem levar em consideração o mais importante: a saúde do paciente. Deve-se buscar a correta aplicação da norma ao caso concreto, mesmo que, para isso, deva ser corrigido eventual equívoco do órgão julgador de origem. Ademais, quando a decisão é confirmada pelo órgão revisor não há esse desprestígio, já que o entendimento do primeiro julgador foi mantido ${ }^{52}$.

Mas, neste caso, surge a segunda desvantagem do duplo grau de jurisdição, que é a inutilidade do segundo julgamento que confirma o primeiro. Se a decisão originária estava correta, o seu reexame terá sido inútil, a apontar a superfluidade do duplo grau de jurisdição ${ }^{53}$.

Apesar de, na prática, não se ter alterado o resultado do processo, a segunda decisão que confirma a primeira pacifica a interpretação legal, diminui o descontentamento do vencido com o resultado do julgamento e efetiva a segurança jurídica ${ }^{54}$. Não se pode dizer que ela é inútil, portanto.

\footnotetext{
${ }^{49}$ KOZIKOSKI, 2011, p. 145.

${ }^{50}$ MARINONI e ARENHART, 2011, p. 488.

${ }^{51}$ KOZIKOSKI, 2011, pp. 145/146.

${ }^{52}$ MARCATO, 2006, pp. 48/49.

${ }^{53}$ CINTRA, GRINOVER e DINAMARCO, 2006, pp. 80/81.

${ }^{54}$ MARCATO, 2006, p. 49.
} 
Mesmo quando a segunda decisão altera a primeira, a doutrina aponta a desvantagem de que se cria um inconveniente para o Judiciário, já que a aplicação da lei ao caso concreto se torna controvertida ${ }^{55}$.

Essa controvérsia específica só ocorre porque a segunda decisão corrige o que se entende ser um erro da primeira, efetivando a segurança jurídica, não se podendo qualificar essa como uma desvantagem do duplo grau de jurisdição, portanto.

Outro aspecto negativo do duplo grau de jurisdição é o fato de que o segundo órgão julgador também é suscetível a erros, podendo mesmo modificar uma primeira decisão correta $^{56}$.

Conforma já exposto anteriormente, o duplo grau de jurisdição não assegura a eliminação de erros, pois todos os juízes são humanos, mas diminui a probabilidade que ele ocorra, por ser um reexame do que já foi decidido e, por ser feito, no mais das vezes, por pessoas mais experientes e de maneira colegiada.

Assim, ainda que o duplo grau de jurisdição não extirpe o erro da decisão judicial, ele contribui para tanto, não havendo que se falar em desvantagem do instituto por esse aspecto.

O duplo grau de jurisdição também seria nocivo, pois violaria a oralidade, já que o segundo juiz não tem contato direto com as partes e com as provas, o que prejudicaria a busca da verdade real ${ }^{57}$.

De fato, em geral, o segundo grau não tem contato direto com provas e partes, tendo conhecimento da causa apenas por documentos escritos, enquanto o primeiro juiz, na maioria dos casos, tem esse contato quando é realizada audiência.

Porém, o princípio da oralidade já é tão mitigado no ordenamento jurídico pátrio que não se pode afirmar que o duplo grau de jurisdição é o responsável pela sua inobservância ${ }^{58}$.

\footnotetext{
${ }^{55}$ CINTRA, GRINOVER e DINAMARCO, 2006, p. 81; e KOZIKOSKI, 2011, pp. 145/146.

${ }^{56}$ NERY JÚNIOR, 2004, p. 37.

${ }^{57}$ LASPRO, 1995, p. 172.

58 "Primeiramente não deixa de ser curiosa a utilização do princípio da oralidade para afastar o duplo grau de jurisdição. É indiscutível que o princípio da oralidade possui fundamental relevância e ainda desperta viva controvérsia, mas também não se pode negar que seus corolários são ignorados rotineiramente no processo civil brasileiro. Parece-nos que a oralidade só é lembrada como argumento contra o duplo grau de jurisdição, restando esquecida nos demais campos processuais. Nem é necessário lembrar os casos em que a matéria é meramente de direito e há julgamento antecipado do mérito, bastando ter me mente que nossa sistemática e a prática judiciária são divorciadas do princípio da oralidade. É uma falácia afirmar que vivemos em um sistema de oralidade, quando não há uma séria fase de conciliação e quando os julgadores cada vez mais prestigiam audiências sintéticas e manifestações escritas. Até mesmo o mobiliário das salas de audiência, com anacrônicos tablados, por exemplo, vai contra o espírito da oralidade. Repita-se que a objeção argumentativa é relevante, mas não se pode deixar de mencionar que, ao menos no discurso ordinário do processo brasileiro, o princípio da oralidade somente assume lugar nobre para servir de argumento contrário ao duplo grau de jurisdição. Acrescente, ainda, que 'não se pode dizer que a oralidade é perdida, pois num sistema em que a motivação é obrigatória e o duplo grau existe, o juiz deve trazer na sentença aqueles elementos que a oralidade lhe proporcionou, não só para o duplo grau, mas para a própria interpretação da sentença. Qualquer elemento de caráter puramente psicológico
} 
Não são raros os casos em que não é realizada audiência de instrução e julgamento, partindose para o julgamento antecipado ou porque a colheita de prova oral é dispensável. A enorme maioria dos atos processuais é escrita, tanto em primeiro, quanto nos demais graus de jurisdição.

Assim, a oralidade já é princípio bastante mitigado na atual prática forense, não podendo justificar a eliminação do duplo grau de jurisdição.

Além disso, com a aplicação da tecnologia ao processo, já se mostra possível a gravação de audiências em vídeo, que poderá ser assistido pelo segundo juiz, diminuindo consideravelmente o impacto da perda da oralidade.

Por último, considera-se que a única real desvantagem do duplo grau de jurisdição é o aumento da duração do processo e do seu custo. Ao levar a causa a novo exame de outro juízo, perpetuasse o processo no tempo, alongando, às vezes de maneira excessiva, a sua duração ${ }^{59}$. Os custos, tanto para as partes, quanto para o Estado, também crescem quanto mais tempo tramita o processo, pois se exigem o pagamento de custas processuais, o armazenamento dos autos físicos, a contratação de funcionários, a incidência de juros e correção monetária sobre eventuais condenações etc.

Pôr fim ao duplo grau de jurisdição, sem dúvida, diminuiria a duração dos processos e os tornaria mais baratos, sendo esta uma desvantagem do instituto ${ }^{60}$.

Todavia, ao mesmo tempo que um processo mais longo e caro é prejudicial, um processo injusto é ainda mais danoso ${ }^{61}$. E o duplo grau de jurisdição, conforme exposto

que tenha sido relevante o suficiente para que o mesmo consolidasse tal fato na sentença não tem qualquer valor sob o ponto de vista jurídico'." (GODINHO, 2011, pp. 514/515).

${ }^{59}$ MARINONI e ARENHART, 2011, p. 490.

${ }^{60}$ Não só diminuiria o tempo normal de duração do processo, como também as chamadas fases mortas, aquelas em que simplesmente se aguarda a prática de um ato processual, em geral pelo juiz. Pode se verificar o que caracteriza o "tempo inimigo" em se adotando os critérios estabelecidos pela Corte Europeia de Direitos Humanos: a complexidade da causa, comportamento das partes no curso do processo e atuação do órgão jurisdicional (CRUZ E TUCCI, 2011, p. 199).

61 “Em segundo lugar, está claro que os processos podem ter duração muito prolongada, causando prejuízos às partes; entretanto, maior ofensa ao acesso à justiça será a vedação ao grau recursal, impedindo o reexame da matéria e ferindo o direito da parte de buscar a consecução da tutela jurisdicional que pretende. Isso fica ainda mais evidenciado levando-se em conta a ideia de que a natureza jurídica do recurso é o prolongamento do direito de ação; nessa medida, uma sentença desfavorável levaria ao surgimento de um nova lesão (perda do bem da vida) que não poderia ser afastada do conhecimento pelo órgão jurisdicional.

(...) É evidente que não existem certezas e seguranças absolutas; entretanto, os escopos do processo estão voltados, primordialmente, a assegurar esses valores tanto quanto possível. É certo também, que a virtude encontra-se no meio-termo, razão pela qual se deve almejar um processo que assegure maior confiança ao jurisdicionado e, ao mesmo tempo, tenha apenas a duração necessária.

Como quer que seja, é salutar considerar social e juridicamente correta a concessão, à parte que se sente injustiçada com o resultado da demanda, do direito de recorrer da decisão que lhe pareça errada ou injusta, e com a qual esteja inconformada, na medida em que assim se assegura a pacificação social, um dos escopos do processo." (MARCATO, 2006, pp. 47/51). 
acima, contribui para a redução das injustiças, ao permitir um segundo reexame completo da causa, no mesmo processo, por outro órgão julgador ${ }^{62}$.

É melhor que o processo seja um pouco mais demorado e caro, mas que seja mais apto a alcançar uma decisão justa, do que seja mais célere e barato, mas com menor probabilidade de pacificar o conflito entre as partes de forma adequada ${ }^{63}$.

Dessa forma, ainda que o duplo grau de jurisdição tenha desvantagens, as suas vantagens as superam, a justificar a manutenção do instituto no nosso ordenamento jurídico.

Todavia, manter o duplo grau de jurisdição no ordenamento jurídico nacional não significa a sua aplicação irrestrita a qualquer processo. Possível se pensar em casos em que ele pode ser limitado, mas a discussão escapa do escopo deste trabalho.

\subsection{Duplo grau de jurisdição: natureza constitucional?}

Conceituado duplo grau de jurisdição e abordadas suas vantagens e desvantagens, deve-se verificar se o instituto jurídico tem ou não natureza constitucional. Essa indagação é relevante porque a duração razoável do processo é uma garantia constitucional, prevista no artigo 5', LXXVIII, da Constituição Federal e, conforme exposto acima, o duplo grau de jurisdição é um óbice à efetivação dessa garantia.

A Constituição Federal e o Código de Processo Civil silenciam sobre o duplo grau de jurisdição ${ }^{64}$. Não há texto legal expresso que o preveja, no ordenamento jurídico brasileiro.

Porém, o simples fato de a Carta Magna não tratar expressamente do duplo grau de jurisdição não significa que o instituto não tenha caráter constitucional, já que existem as normas constitucionais implícitas, conforme lição de PAULO BONAVIDES ${ }^{65}$.

É minoritária a corrente doutrinária que aponta que o duplo grau de jurisdição não tem natureza constitucional.

São duas as justificativas para essa parte dos doutrinadores: (i) a não previsão expressa do duplo grau de jurisdição no texto constitucional ${ }^{66}$, e (ii) o fato de haver exceções ao duplo

\footnotetext{
${ }^{62} \mathrm{O}$ confronto desses institutos jurídicos do ponto de vista constitucional será abordado em seguida.

${ }^{63}$ HOFFMAN, 2006, p. 41.

${ }^{64}$ MARCATO, 2006, p. 22.

65 "Não é possível, segundo ele [Carl Schmitt], dissolver a Constituição num feixe de leis constitucionais isoladas. Toda teoria constitucional principia com aquela distinção entre Constituição e lei da Constituição. A Constituição na acepção positiva emana, segundo Schmitt, de um ato do poder constituinte. A vontade política unitária existente é que se decide por uma Constituição; ela é o próprio Estado, ou seja, a unidade política do povo, capaz de introduzir novas formas fundamentais na organização.” (BONAVIDES, 2012, pp. 182/183).

${ }^{66}$ KOZIKOSKI, 2011, pp. 153/154; e SOUZA, 2011, pp. 62/63.
} 
grau de jurisdição, tanto de natureza constitucional quanto infraconstitucional, a demonstrar que ele não está garantido pela Lei Maior ${ }^{67}$.

Respeitada essa posição, não se pode concordar com ela. Conforme já exposto, o simples fato de não haver menção expressa ao duplo grau de jurisdição pela Constituição Federal não significa que este não seja instituto jurídico constitucional, pois há princípios implícitos. E os autores que apontam haver exceções ao duplo grau, o que afastaria a sua natureza constitucional confundem norma constitucional com garantia constitucional, institutos bastante diversos, como se verá no item 2.3 desta dissertação.

A corrente absolutamente majoritária da doutrina, por outro lado, afirma que o duplo grau de jurisdição tem natureza constitucional ${ }^{68}$. Já é da tradição dos países de civil law ${ }^{69}$, como o Brasil, preverem recursos que efetivam o duplo grau de jurisdição, razão pela qual se deve concluir que este está implícito constitucionalmente ${ }^{70}$.

São diversos os fundamentos que justificam a conclusão de que o duplo grau de jurisdição está consagrado ao nível constitucional, não havendo contrariedade entre eles, ou seja, todos podem, em conjunto, servir de base para esse entendimento.

O primeiro, e mais controvertido, é o devido processo legal. O duplo grau, para parte da doutrina, seria inerente ao devido processo legal, princípio síntese que justifica todos os outros princípios e regras processuais ${ }^{71}$.

Por isso, poderia se concluir que, desse princípio, decorreria o duplo grau de jurisdição, forma de controlar o respeito à imparcialidade e à independência do juiz, o acesso

\footnotetext{
${ }^{67}$ MENDES e RAGAZZI, 2007, p. 326. No mesmo sentido, mas sem tanta ênfase: LASPRO, 1995, pp. 96/97; LINS, 2006, p. 177; e MARINONI e ARENHART, 2011, pp. 496 e 499.

${ }^{68}$ AMENDOEIRA JR., 2012, p. 30; ASSIS, 2011, p. 74; BUENO, 2011, p. 48; CALMON DE PASSOS, 1982, pp. 02/03; CANOTILHO, 2001, pp. 660/661; CHEIM JORGE, 2011, p. 228; COMOGLIO, 1991, pp. 689/690; DIDIER JR. e CUNHA, 2010, p. 25; DINAMARCO, 2005, pp. 256/257; GONÇALVES, M., 2012a, p. 52; GRECO FILHO, 2010, pp. 73/74; KUKINA, 2003, p. 105; LEAL e PORTO ALEGRE, 2004, p. 729; MACHADO e LEAL JÚNIOR, 2010, pp. 87/88; MARCATO, 2006, pp. 27/28 e 30; MELO, 2005, pp. 670/671 e 676/677; MORAES, 2011m p. 90; NERY JÚNIOR, 2004, p. 40; NOGUEIRA, 2006, pp. 543/545; PASSOS, 1993, p. 155; SORMANI, 2008, p. 237; e TAVARES, 2000, p. 182.

${ }^{69}$ Não só de civil law, mas do mundo ocidental, em que, com a exceção da Turquia - exceção essa apontada em meados da década de 1970 -, nenhum outro ordenamento não previa recurso contra decisão de mérito da causa (MENDONÇA LIMA, 1976, p. 138).

70 "Nell'analisi del modello processuale, si delineano due o tre ulteriori aspetti, non sempre connessi od interdipendenti fra di loro, che non godono di una diretta ed espressa 'copertura' costituzionale (ma aspirano, semmai a riceverne una indiretta ed implicita).

Essi sono:

- in primo luogo, la garanzia del doppio grado di giurisdizione (di merito), profondamente radicata nelle tradizioni europee occidentali, ma non certamente ignota o disconosciuta nei sistemi di common law, la quale esige che, nei confronti delle decisioni pronunziate dai giudici inferiori di prima istanza, sia costantemente assicurati un'oppertunità di revisione e di riesame in un nuovo giudizio, mediante un'impugnazione proposta ad un giudice superiore;" (COMOGLIO, 1998, p. 115).

${ }^{71}$ BUENO, 2012, p. 160; e NERY JÚNIOR, 2010, p. 79.
} 
ao julgador e a efetivação do contraditório ${ }^{72}$, todas garantias constitucionais que decorrem, em última análise, do devido processo legal.

Há inclusive quem afirme que o devido processo legal abarcaria o direito a aspirar a uma decisão judicial favorável, motivo que justificaria a inclusão do duplo grau de jurisdição entre os institutos jurídicos de índole constitucional ${ }^{73}$.

Justamente por ser princípio síntese, é necessário ter muito cuidado ao afirmar que certo instituto jurídico decorre do devido processo legal ${ }^{74}$. Isso porque, sem qualquer limite, todos institutos processuais podem ser reputados como integrantes do devido processo legal, que é o mesmo que dizer que nenhum deles forma esse princípio.

Em análise de diversos ordenamento jurídicos, LUIGI PAOLO COMOGLIO concluiu que o duplo grau de jurisdição é elemento acidental do devido processo legal, ou seja, depende de uma escolha política de cada Estado, não sendo imprescindível para levar a efeito um processo justo $^{75}$.

Não se pode discordar desse raciocínio. A possibilidade de revisão completa do julgamento da causa por outro órgão não integra de forma inexorável as garantias mínimas de um processo justo ${ }^{76}$. Não se pode alçar o duplo grau de jurisdição ao mesmo nível que o contraditório, que a ampla defesa, que a imparcialidade do julgador ou que a igualdade entre os litigantes, por exemplo, pois sem estas não se pode cogitar de um processo justo.

Mas os processos em que não há possibilidade de duplo grau de jurisdição, como as ações objetivas, de competência do Supremo Tribunal Federal, de gigantesco impacto na vida de toda a sociedade brasileira, por exemplo, nem por isso não podem ser considerados observadores do devido processo legal.

Portanto, conclui-se que o devido processo legal não fundamenta a conclusão de que o duplo grau de jurisdição tem natureza constitucional.

\footnotetext{
${ }^{72}$ CALMON DE PASSOS, 1982, pp. 03 e 06.

73 "Quando se alude a bem quer-se compreender na locução todo e qualquer bem da vida, corpóreo ou incorpóreo, nesta última categoria apreendida não só a noção patrimonial economicamente mensurável, mas também aquela que constitui o patrimônio emocional, intelectual e social do ser humano, os direitos que as pessoas têm sobre as coisas, sobre os produtos de seu intelecto ou contra outras pessoas.

Não é absurdo, destarte, incluir nessa categoria a decisão judicial favorável como um bem da vida desejado por qualquer dos contendores. Assim considerada, a aspiração a uma sentença favorável é bem incorpóreo protegido pela cláusula due process of law, que, por sua abrangência, admite a interpretação em seu elastério.

Da cláusula não é o duplo grau, assim, elemento acidental, mas essencial, posto que relativo à sua própria substância e essência." SÁ, p. 100.

74 “A amplitude da cláusula devido processo legal tornaria desnecessária qualquer outra dogmatização principiológica relativamente ao direito processual. Nada obstante, é importante fixarem-se os critérios de incidência do princípio em suas variegadas manifestações, notadamente no que respeita aos limites dessa incidência, oponíveis a tudo e a todos, pois tal irrestringibilidade não se coaduna com o estado de direito nem atende ao interesse público.” (NERY JÚNIOR, 2010, p. 98).

${ }^{75}$ COMOGLIO, 1991, p. 689.

${ }^{76}$ COMOGLIO, 1999, p. 330; e KOZIKOSKI, 2011, p. 150.
} 
A segunda razão pela qual o duplo grau de jurisdição insere-se entre os institutos jurídicos constitucionais é a previsão de tribunais pela Carta Magna.

A previsão de tribunais, sejam ordinários ou superiores, na Constituição Federal leva à conclusão de que deve haver o duplo grau de jurisdição, pois a função precípua dos tribunais é julgar recursos ${ }^{77}$, reexaminando o mérito da causa. Também é expressamente prevista a competência recursal desses tribunais ${ }^{78}$, o que é outra justificativa para essa conclusão.

Os opositores deste entendimento afirmam que os tribunais têm competência originária, ou seja, não têm entre as suas funções apenas o julgamento de recursos.

Não se pode concordar com essa objeção, porque a função natural de um tribunal é funcionar como órgão de revisão. A competência recursal de todos os tribunais brasileiros é muito maior do que a sua competência originária, bem como o número de recursos supera em centenas, se não milhares de vezes, a quantidade de ações originárias. Dizer que os tribunais também têm competência originária e, por isso, não se pode concluir que se prestam a julgar recursos, é extrapolar irracionalmente a exceção, transformando-a a em regra, de forma equivocada.

Sendo assim, conclui-se que o duplo grau de jurisdição tem caráter constitucional em razão da previsão de tribunais e da competência recursal destes pela Carta Magna.

O duplo grau de jurisdição também teria previsão constitucional implícita pela redação do artigo $5^{\circ}, \mathrm{LV}$, da Constituição Federal, que assim dispõe: "aos litigantes, em processo judicial ou administrativo, e aos acusados em geral são assegurados o contraditório e ampla defesa, com os meios e recursos a ela inerentes" (grifos nossos).

Só seria possível interpretar a palavra "recursos" no sentido estrito, técnico, não como sinônimo de meio, ferramenta, porque o dispositivo constitucional já utilizou o termo “meios”, não tendo a lei, sobretudo a Lei Maior, palavras inúteis ${ }^{79}$.

Todavia, recurso não se confunde com duplo grau de jurisdição, conforme será explicado no item 2.5 desta dissertação, bem como a doutrina considera que os recursos a que aduz o artigo $5^{\circ}, \mathrm{LV}$, da Carta Magna seriam apenas os recursos inerentes à ampla defesa, não todo e qualquer recurso ${ }^{80}$.

\footnotetext{
${ }^{77}$ MELLO, 2009, p. 453.

${ }^{78}$ DINAMARCO, 2005, p. 256.

${ }^{79}$ OLIVEIRA, 2008, p. 371.

80 "Quando a Constituição Federal afirma que estão assegurados o contraditório e a ampla defesa, com os recursos a ele inerentes, ela não está dizendo que toda e qualquer demanda em que é assegurada a ampla defesa deva sujeitar-se a uma revisão a um duplo juízo. Os recursos nem sempre são inerentes à ampla defesa. Nos casos em que não é razoável a previsão de um duplo juízo sobre o mérito, como nas hipóteses das causas denominadas de 'menor complexidade' - que sofrem os efeitos benéficos da oralidade -, ou em outras, assim
} 
Pelo exposto, não se pode concluir que o duplo grau de jurisdição decorre do referido dispositivo constitucional.

Por fim, dois outros fundamentos são apontados para justificar a natureza constitucional do duplo grau de jurisdição: a efetivação do contraditório ${ }^{81}$ e a garantia do Estado Democrático de Direito ${ }^{82}$.

Também não há como se concordar com essas posições, absolutamente minoritárias. Duplo grau de jurisdição não tem relação direta ou vinculante com contraditório. $\mathrm{O}$ contraditório já se efetivou em primeiro grau, sendo a inovação e os debates no segundo julgamento muito mais limitados que no primeiro. Da mesma forma, dizer que o duplo grau garante o Estado Democrático de Direito é alargar demais esse conceito, valendo aqui as mesmas considerações feitas quando analisado o devido processo legal.

\subsection{Duplo grau de jurisdição: regra, princípio ou garantia constitucional?}

Há diversos conceitos de regra, de princípio e de garantia ${ }^{83}$, desenvolvidos por estudiosos da Teoria Geral do Direito ${ }^{84}$, do Direito Constitucional ${ }^{85}$, do Direito

não definidas, mas que também possam justificar, racionalmente, uma única decisão, não há inconstitucionalidade na dispensa do duplo juizo." (MARINONI e ARENHART, 2011, pp. 493/494).

${ }^{81}$ CARVALHO, 2010, pp. 83/84.

${ }^{82}$ MACHADO e LEAL JÚNIOR, 2010, pp. 87/88.

${ }^{83}$ MARCATO, 2006, p. 03.

${ }^{84}$ NELSON NERY JÚNIOR (2010, p. 21) cita uma série de juristas, em sua maioria especialistas em teoria geral, que abordaram a matéria: "Há as construções e sistematizações de Peter Häberle, Robert Alexy, Ronald Dworkin, Carl Schmitt, José Joaquim Gomes Canotilho, Virgílio Afonso da Silva, Friedrich Müller, ClausWilhelm Canaris, Karl Larenz, Josef Esser, Niklas Luhmann, Eduardo García de Enterría, Karl Engish, Alf Ross, entre outros.".

${ }^{85}$ JOSÉ AFONSO DA SILVA (2011, pp. 91/92) distingue norma de princípio: “As normas são preceitos que tutelam situações subjetivas de vantagem ou de vínculo, ou seja, reconhecem, por um lado, a pessoas ou a entidades a faculdade de realizar certos interesses por ato próprio ou exigindo ação ou abstenção de outrem, e, por outro lado, vinculam pessoas ou entidades à obrigação de submeter-se às exigências de realizar uma prestação, ação ou abstenção em favor de outrem. Os princípios são ordenações que se irradiam e imantam os sistemas de normas, são [como observação Gomes Canotilho e Vital Moreira] 'núcleos de condensações' nos quais confluem valores e bens constitucionais. Mas, como disseram os mesmos autores, 'os princípios, que começam por ser a base de normas jurídicas, podem estar positivamente incorporados, transformando-se em normas-princípio e constituindo preceitos básicos de organização constitucional'.”.

Já PAUlo BONAVIDES (2012, pp. 298/299) conceitua norma, regra e princípio de forma extremamente similar à sistemática adota neste trabalho: "Tudo quanto escrevemos fartamente acerca dos princípios, em busca de sua normatividade, a mais alta de todo o sistema, porquanto quem os decepa arranca as raízes de árvore jurídica, se resumo no seguinte: não há distinção entre princípios e normas, os princípios são dotados de normatividade, as normas compreendem regras e princípios, a distinção relevante não é, como nos primórdios da doutrina, entre princípios e normas, mas entre regras e princípios, sendo as normas o gênero, e as regras e os princípios a espécie.

(...) As regras vigem, os princípios valem; o valor que neles se insere se exprime em graus distintos. Os princípios, enquanto valores fundamentais, governam a Constituição, o regímen, a ordem jurídica. Não são apenas a lei, mas o Direito em toda sua extensão, substancialidade, plenitude e abrangência.”. 
Administrativo $^{86}$, do Direito Processual Civil ${ }^{87}$ etc. Essa diversidade de conceitos dificulta a coerência entre eles, sendo que, por vezes, fala-se em um desses institutos jurídicos com um significado completamente diferente do que o leitor entende; ou se mistura teorias distintas, criando um sincretismo inaceitável ${ }^{88}$.

Daí a necessidade de se estabelecer o que será considerado regra, princípio e garantia nesta dissertação, para que o texto seja coerente e não confunda o leitor, que já tem uma ideia pré-concebida desses conceitos.

Adotaremos a distinção feita por ROBERT AlEXY entre regra e princípio ${ }^{89}$. Para o renomado jurista alemão, regra e princípio sãos as duas espécies de norma.

Regras são determinações, aplicáveis ou não no caso concreto ${ }^{90}$. Já princípios são mandamentos de otimização, que regem a atividade legislativa e interpretativa do Direito, e devem ser efetivados na maior medida possível ${ }^{91}$. Ambos têm caráter normativo, ou seja, "ambos dizem o que deve ser. Ambos podem ser formulados por meio de expressões deônticas

O autor também trata de garantia, em confronto com o conceito de direito (pp. 541/545) e define garantia assim: "Por aí se percebe a amplitude das garantias constitucionais bem como seu valor instrumental de meio defensivo, invariavelmente vinculado a uma prestação do Estado, ou seja, dos poderes públicos, quer pela via constituinte constituída (a reforma da Constituição pelo Legislativo), quer pelas regulares e ordinárias de exercício da função jurisdicional (Poder Judiciário). Mas não é possível fazê-las eficazes senão num ordenamento que concretize em toda a plenitude os postulados do Estado de Direito, sem os quais nem vinga a liberdade nem os direitos humanos têm adequada proteção." p. 550.

${ }^{86}$ O conceito de princípio para CELSO AnTÔNio BAndeIRA De Mello (2012, p. 54) é o seguinte: "Princípio é, pois, por definição, mandamento nuclear de um sistema, verdadeiro alicerce dele, disposição fundamental que se irradia sobre diferentes normas, compondo-lhes o espírito e servindo de critério para exata compreensão e inteligência delas, exatamente porque define a lógica e a racionalidade do sistema normativo, conferindo-lhe a tônica que lhe dá sentido harmônico.".

${ }^{87}$ CÂNDIDO RANGEl DiNAMARCO (2005, p. 214) distingue principio de garantia da seguinte forma: "Mas a tutela constitucional do processo não seria efetiva se as grandes linhas-mestras desenhadas pela Constituição (princípios) não ganhassem eficácia imperativa mediante as correspondentes garantias. Consistem as garantias constitucionais em preceitos dotados de sanção, isso significando que sua inobservância afetará de algum modo a validade ou eficácia do ato transgressor, o qual não pode prevalecer sobre os imperativos constitucionais. Por isso é que geralmente os dispositivos constitucionais reveladores dos grandes princípios são encarados como garantias, a ponto de ser usual o uso indiferente dos vocábulos princípio e garantia para designar a mesma ideia.".

${ }^{88}$ NERY JÚNIOR, 2010, pp. 34/35.

${ }^{89}$ Distinção esta feita na clássica obra Teoria dos direitos fundamentais.

90 “Já as regras são normas que são sempre ou satisfeitas ou não satisfeitas. Se uma regra vale, então, deve se fazer exatamente aquilo que ela exige; nem mais, nem menos. Regras contêm, portanto, determinações no âmbito daquilo que é fática e juridicamente possível. Isso significa que a distinção entre regras e princípios é uma distinção qualitativa, e não uma distinção de grau. Toda norma é ou uma regra ou um princípio." (ALEXY, 2008, p. 91).

91 “O ponto decisivo na distinção entre regras e princípios é que princípios são normas que ordenam que algo seja realizado na maior medida possível dentro das possibilidades jurídicas e fáticas existentes. Princípios são, por conseguinte, mandamentos de otimização, que são caracterizados por poderem ser satisfeitos em graus variados e pelo fato de que a medida devida de sua satisfação não depende somente das possibilidades fáticas, mas também das possibilidades jurídicas. $\mathrm{O}$ âmbito das possibilidades jurídicas é determinado pelos princípios e regras colidentes.” (Idem, p. 90). 
básicas do dever, da permissão e da proibição. Princípios são, tanto quanto as regras, razões para juízos concretos de dever-ser, ainda que de espécies muito diferentes." ${ }^{.92}$.

Em um conflito de regras, há antinomia, ou seja, uma delas deve ser reputada inválida para que apenas a outra permaneça vigente no ordenamento jurídico ${ }^{93}$. Não pode, por exemplo, uma lei dispor que a idade mínima para ser candidato a cargo eletivo é 18 anos e outra, ao mesmo tempo, prever que essa idade mínima é de 21 anos. Umas das regras é inválida e deve ser extirpada do sistema.

Por outro lado, quando dois princípios são conflitantes, ambos permanecem válidos ${ }^{94}$, mas, por meio da ponderação e se aplicando a proporcionalidade ${ }^{95}$, um deles deve ser aplicado no caso concreto em detrimento do outro, que pode vir a ser aplicado em outra hipótese, por ter maior valor que o primeiro. Para exemplificar a questão, cita-se o princípio do contraditório, que pode vir a ceder, excepcionalmente, na concessão de medida liminar inaudita altera parte (artigos 273, 797, 804, 928, 937 e 1.051 do CPC, p. ex.), mas jamais deve ceder quando se trata da formação da relação jurídico-processual por meio da citação ${ }^{96}$.

A distinção feita por ROBERT ALEXY está consagrada na doutrina, nacional e internacional, sendo didática, coerente e conhecida. Por isso se decidiu pela sua adoção nesta dissertação.

No entanto, na obra de ROBERT ALEXY não há um conceito claro do que seria garantia. Por isso, para definir o que é garantia, deve-se valer da noção exposta por J. J. Gomes CANOTILHO, que parte das premissas fixadas por RoBERT ALEXY e as desenvolve ${ }^{97}$, definindo garantia como uma das subespécies de princípio.

O princípio, em sentido estrito, nesta dissertação, é o que J. J. GoMES CANOTILHO chama de princípio jurídico fundamental: "os princípios historicamente objectivados e progressivamente introduzidos na consciência jurídica e que encontram uma recepção

\footnotetext{
92 Idem, p. 87.

${ }^{93}$ Idem, p. 92.

${ }^{94}$ Idem, pp. 93/94.

95 Idem, pp. $117 / 118$.

${ }^{96}$ Pode, inclusive, dar ensejo à querela nullitatis.

97 Após diferenciar regras e princípios como espécies de norma, o constitucionalista português faz a seguinte referência, em nota de rodapé: "Seguimos de perto, ALEXY, Thorie der Grundrechte, cit., pp. 75 e ss.; DWORKIN, Taking Rights Serously, pp. 116 e ss.; ZAGREBELSKY, Il sistema costituzionale dele fonti del diritto, p. 108. Cfr. Também Eros R. GraU, A ordem econômica, cit., pp. 107 e ss.; M. BorowsKy, 'Pinzipien...', cit., p. 309 ss.” (CANOTILHO, 2001, p. 1.146).
} 
expressa ou implícita no texto constitucional ${ }^{98}$. São princípios que integram o ordenamento jurídico e ordenam a aplicação, a interpretação e a criação do direito ${ }^{99}$.

Já garantia é a subespécie de princípio denominada de princípio-garantia pelo renomado constitucionalista português. Vinculam o legislador à sua aplicação, constituindo um instrumento de efetivar direitos que o cidadão tenha em relação ao Estado ${ }^{100}$.

Portanto, considera-se regra a norma que determina uma providência e é válida se não houver antinomia com outra regra que a invalide; princípio é um mandamento de otimização, que deve ser efetivado na maior medida possível, dentro dos limites fáticos e jurídicos, e que pode ser sopesado quando em confronto com outro princípio; e garantia é um tipo de princípio que instrumentaliza a norma, obrigando a sua observância por todos.

São esses os conceitos de regra, princípio e garantia que serão utilizados nesta dissertação, devendo o duplo grau de jurisdição ser encaixado em um deles, nunca esquecendo que se trata de instituto jurídico de natureza constitucional, para se verificar em que medida deve ser aplicado no ordenamento jurídico pátrio.

\subsubsection{Duplo grau de jurisdição como regra}

Apenas um autor entende que o duplo grau de jurisdição seria uma regra: GUILHERME PUChALSKI TEIXEIRA ${ }^{101}$. Porém, não parece que essa conceituação tenha sido feita da forma mais precisa, pois afirma que a regra do duplo grau de jurisdição pode ser relativizada, mas

\footnotetext{
${ }^{98}$ Idem, p. 1.149 .

99 “(...) Pertencem à ordem jurídica positiva e constituem um importante fundamento para a interpretação, integração, conhecimento e aplicação do direito positivo. Mais rigorosamente, dir-se-á, em primeiro lugar, que os princípios têm uma função negativa particularmente relevante nos 'casos limites' ('Estado de Direito e de Não Direito', 'Estado Democrático e ditadura'). (...)

Os princípios jurídicos gerais têm também uma função positiva, 'informando' materialmente os actos dos poderes públicos. (...)” (Idem, p. 1.149).

100 "Há outros princípios que visam instituir directa e imediatamente uma garantia dos cidadãos. É-lhes atribuída uma densidade de autêntica norma jurídica e uma força determinante, positiva e negativa. Refiram-se, a título de exemplo, o princípio de nullum crimen sine lege e de nulla poena sine lege (cfr. art. 29. ${ }^{\circ}$ ), o princípio do juiz natural (cfr. art. 32.\%/7), os princípios de non bis in idem e in dubio pro reo (cfr. arts. 29.\%/4, 32.\%/2).

Como se disse, estes princípios traduzem-se no estabelecimento directo de garantias para os cidadãos e daí que os autores lhe chamem 'princípios em forma de norma jurídica' (Larenz) e considerem o legislador estreitamente vinculado na sua aplicação.” (Idem, p. 1.151).

101 "É ponto de convergência entre a doutrina de Dworkin, Alexy e, mais recentemente, Ávila, a constatação de que as regras 'possuem um elemento frontalmente descritivo, ao passo que os princípios apenas estabelecem uma diretriz'.

Parece nítida a constatação de que o duplo grau não se ajusta ao efeito de indicar uma diretriz. Ou ele incide ou não incide. Ou há a previsão legal para um segundo julgamento, ou não há, ajustando-se à noção de all or nothing a que se refere Dworkin.” (TEIXEIRA, 2008, p. 345).
} 
não excluída por completo, sendo obrigatória nos casos da apelação e do recurso ordinário constitucional $^{102}$.

Por esse raciocínio, o duplo grau não seria regra, mas sim princípio, já que deve ser efetivado ao máximo, mas pode não ser aplicado em casos específicos.

O duplo grau de jurisdição não é regra, porque não é válido ou inválido de forma definitiva, quando confrontado com outras regras ${ }^{103}$. Há diversas exceções ao duplo grau de jurisdição, tanto no texto constitucional - ações de competência originária do Supremo Tribunal Federal (art. 102, I), por exemplo -, quanto no infraconstitucional - embargos infringentes de alçada em execuções fiscais (art. 34, $\S \S 2^{\circ}$ e $3^{\circ}$, da Lei $n^{\circ} 6.830 / 1980$ ).

\subsubsection{Duplo grau de jurisdição como princípio}

Em havendo apenas duas espécies de norma e não sendo o duplo grau de jurisdição regra, logicamente se chega à conclusão de que se trata de princípio constitucional.

O duplo grau de jurisdição é uma diretriz, um mandamento de otimização, que deve ser seguido pelo legislador e pelo intérprete de modo a efetivá-lo ao máximo, dentro das limitações fáticas e jurídicas de cada ordenamento jurídico. Ele pode ceder a outro princípio em determinado caso concreto, como também pode prevalecer sobre esse mesmo princípio em hipótese diversa ${ }^{104}$.

Essa é a posição adotada pela grande maioria da doutrina ${ }^{105}$ e também pela jurisprudência da mais alta Corte brasileira ${ }^{106}$.

\footnotetext{
102 "De outro lado, não será legítima, muito menos constitucional, legislação ordinária que suprima os recursos que hoje refletem o duplo grau em nosso ordenamento, quais sejam: o recurso de apelação e o recurso ordinário constitucional.

O que se admite, a luz da Constituição, é a formulação de exceções ao duplo grau, conquanto específicas e razoavelmente justificadas pela busca em conferir maior celeridade à prestação jurisdicional.

Ao legislador ordinário caberá este difícil temperamento, visto que a ele caberá legislar sobre direito processual $(\mathrm{CF} / 88$, art. 22, I), conquanto não elimine ou suprima por inteiro os recursos que garantem o amplo reexame das decisões finais e antecipatórias de tutela.

A possibilidade de relativização da regra, ao menos em relação às causas de competência dos juízes, justifica a constitucionalidade das laterações recentes ao Código de Processo Civil, a seguir tratadas separadamente." (Idem, p. 351).

${ }^{103}$ Tem o mesmo entendimento ANA CÂNDIDA MENEZes MARCATO (2006, pp. 10/11): "Posto isso, acreditamos que o duplo grau de jurisdição se enquadra na categoria de princípio não de regra. Basta pensar que o duplo grau não traz aplicação cogente, obrigatória, sob pena de invalidade. Ao contrário, a sua aplicação - como veremos nos tópicos seguintes - comporta exceções constitucionais e legais; entretanto, nem por isso ele é considerado inválido e não pertencente ao ordenamento jurídico. Em outras palavras, o duplo grau de jurisdição pode ser relativizado em face de outros princípios, ou afastado em virtude de exceções legais, mas continuará integrando o ordenamento jurídico.”.

${ }^{104}$ MARCATO, 2006, p. 71.

${ }^{105}$ AMENDOEIRA JR, 2012, p. 30; ASSIS, 2011, p. 74; BECKER, 2005, p. 150; BUENO, 2011, p. 48; DIDIER JR. e CUNHA, 2010, pp. 25/26; DINAMARCO, 2005, p. 214; KUKINA, 2003, p. 105; MACHADO e
} 
Dessa forma, ao se conceituar o duplo grau de jurisdição como princípio constitucional se autoriza o seu confronto com o princípio constitucional da duração razoável do processo, devendo ambos ser ponderados em cada caso concreto, de acordo com as circunstâncias específicas.

O duplo grau de jurisdição é forma de efetivar a segurança jurídica, permitindo uma segunda análise completa da causa por diferente juiz. Em determinados casos, entende-se que é preferível um processo mais seguro, ainda que ele seja mais lento, afastando a aplicação do princípio da duração razoável do processo naquela hipótese. Em outros, o duplo grau cede à celeridade, preferindo-se um processo que dure menos tempo, ainda que o risco de injustiça seja majorado $^{107}$.

\subsubsection{Duplo grau de jurisdição como garantia}

Resta, por fim, determinar se o duplo grau de jurisdição, como princípio constitucional que é, também se enquadra na subespécie de garantia constitucional.

Novamente, apenas uma doutrinadora preceitua que o duplo grau seria uma garantia: DJANiRA MARIA RADAmÉS DE SÁ. Para ela, o duplo grau de jurisdição decorre do devido processo legal e, assim como este, não aceita qualquer limitação ${ }^{108}$.

Em suas palavras:

De tudo quanto se analisou a respeito do alcance e da utilidade do princípio do duplo grau de jurisdição resta a conclusão de que quanto mais se examina uma sentença, mais perfeita é a distribuição da justiça, o que equivale a dizer que o princípio não só constitui garantia fundamental de boa justiça, como se revela essencial à organização judiciária. ${ }^{109}$

LEAL JÚNIOR, 2010, p. 87/88; MARCATO, 2006, pp. 127/128; MORAES, 2011, p. 90; NOGUEIRA, 2006, pp. 543/545; e TAVARES, 2000, p. 182.

${ }^{106}$ Nesse sentido: AI no 698287/SP, Rel. Min. Ellen Gracie, 2a Turma, j. 02/08/2011; AI no 662.011/CE, Rel. Min. Dias Toffoli, $1^{\text {a }}$ Turma, j. 15/02/2011; AI 601832/SP, Rel. Min. Joaquim Barbosa, $2^{\text {a }}$ Turma, j. 17/03/2009; QO em MI no 635/DF, Rel. Min. Nelson Jobim, Pleno, j. 29/06/2001 e MI nº 04/DF, Rel. Min. Moreira Alves, Tribunal Pleno, j. 13/10/1988.

107 "E, no Brasil, é a própria Constituição Federal que dá a tônica, os contornos e os limites do duplo grau de jurisdição. Assim, para que se efetive o binômio segurança-justiça, os litígios poderiam perpetuar-se no tempo, a pretexto de conferirem maior segurança àqueles que estão em juízo buscando a atividade jurisdicional substituidora de suas vontades. O objetivo do duplo grau de jurisdição é, portanto, fazer adequação entre a realidade no contexto social de cada país e o direito à segurança e à justiça das decisões judiciais, que todos têm de acordo com a Constituição Federal.” (NERY JÚNIOR, 2004, p. 40).

${ }^{108}$ SÁ, 1999, pp. 90/91.

${ }^{109}$ Idem, pp. 98/99 
A doutrina majoritária discorda desse entendimento ${ }^{110}$. Aponta-se que o duplo grau de jurisdição é excepcionado pela própria Carta Magna, por isso não pode ser alçado ao patamar de garantia constitucional. Essa também a posição do Supremo Tribunal Federal ${ }^{111}$.

Respeitadas essas posições, não parece que seja essa a lógica a ser empregada para verificar se o duplo grau de jurisdição é ou não uma garantia. Dizer que um princípio é também uma garantia não significa impedir a sua exceção ${ }^{112}$. Os princípios-garantia, assim como todos os outros, cedem a outros princípios dependendo das circunstâncias de cada caso. A vida, por exemplo, uma das maiores garantias constitucionais e direito fundamental do ser humano, cede em certos casos, como na pena de morte. A liberdade também pode ser limitada, nos inúmeros casos de penas privativas de liberdade, impostas diariamente em todo o mundo.

Para se determinar se um princípio é também uma garantia ou não, deve-se analisar se ele constitui um instrumento efetivo a ser usado pelo cidadão em face do Estado. No caso, deve-se verificar se a Constituição Federal, de alguma forma, garantiu uma ferramenta de uso amplo e irrestrito para que o duplo grau de jurisdição seja levado a efeito, para que ele possa ser classificado como garantia constitucional.

E, pela análise do texto constitucional, bem como pela interpretação das normas dessa natureza, a resposta é negativa. Não há um instrumento de natureza constitucional que garanta a todos a observância do duplo grau de jurisdição como mandamento de otimização.

Previu-se, na Constituição Federal, apenas um meio para assegurar o duplo grau de jurisdição: o recurso ordinário constitucional. Mas este tem hipóteses de cabimento tão restritas, apesar de importantes, que não pode ser encarado como a garantia geral do duplo grau de jurisdição. Neste caso, se garantiu o duplo grau de jurisdição, mas não se pode extrapolar essa hipótese bastante restrita para o restante dos $\operatorname{casos}^{113}$.

Dessa forma, conclui-se que o duplo grau de jurisdição é princípio constitucional, mas não, também, uma garantia constitucional.

\footnotetext{
${ }^{110}$ DINAMARCO, 2005, p. 214; LASPRO, 1995, p. 159; MARCATO, 2006, p. 32; MENDES e BRANCO, 2011, p. 441; e NERY JÚNIOR, 2010, pp. 284/285.

${ }_{111}$ Pode-se citar: RHC no 79.785/RJ, Rel. Min. Sepúlveda Pertence, Tribunal Pleno, j. 29/03/2000; AI no 209.954/SP, Rel. Min. Marco Aurélio, 2ª Turma, j. 15/09/1998; e AI nº 210.048/SP, Rel. Min. Marco Aurélio, $2^{\mathrm{a}}$ Turma, j. 04/12/1998.

${ }^{112}$ GRECO FILHO, 2010, pp. 73/74.

${ }^{113}$ LASPRO, 1995, p. 156.
} 


\subsection{Conceito de recurso no direito brasileiro}

Diferentemente do duplo grau de jurisdição, que é instituto jurídico entendido de maneira uniforme nos ordenamentos jurídicos nacional e estrangeiros, recurso deve ser conceituado à luz do direito brasileiro. Isso porque há ordenamentos jurídicos estrangeiros, como os da Itália, da Espanha e de Portugal, que classificam como recurso o que no Brasil é classificado como meio autônomo de impugnação de decisões judiciais ${ }^{114}$.

Vale-se, aqui, do conceito de recurso exposto por BERnARDo PIMENTEL SOUZA:

Em sentido estrito, ou seja, em linguagem técnica, e à luz do direito brasileiro, o recurso pode ser assim definido: ato processual que pode ser praticado voluntariamente pelas partes, pelo Ministério Público e até por terceiro prejudicado, em prazo peremptório, apto a ensejar a reforma, a cassação, a integração ou o esclarecimento de decisão jurisdicional, pelo próprio julgador ou por tribunal ad quem, dentro do mesmo processo em que foi proferido o pronunciamento causador do inconformismo. ${ }^{115}$

Ou seja, o que diferencia o recurso dos demais meios de impugnação das decisões judiciais é que ele sempre é voluntário ${ }^{116}$ e sempre se desenvolve no mesmo processo ${ }^{117}$. Não necessariamente nos mesmos autos, como é o caso do agravo de instrumento, por exemplo, mas o recurso não dá ensejo à instauração de uma nova relação jurídico-processual.

Voluntariedade e impugnação no mesmo processo devem sempre ser verificados em conjunto, pois há meios de impugnar decisão judicial voluntariamente que instauram novo processo - a ação rescisória e o mandado de segurança, por exemplo - e há como a decisão judicial ser revista no mesmo processo, mas involuntariamente - o famigerado reexame necessário ou remessa obrigatória.

\footnotetext{
114 “Já se assinalou que, nas exposições clássicas da matéria, é a relação de cada uma delas com a coisa julgada que ministra o critério basilar para a diferenciação entre as duas grandes espécies, acima indicadas, de remédios. Essa linha divisória logicamente deveria apagar-se nos ordenamentos influenciados pela tendência, que a partir de certa época se difundiu, a converter em simples razões de recorribilidade os motivos que antes levavam à invalidação da sentença: a consequência seria a absorção das ações impugnativas autônomas pelos recursos. Manteve-se a separação, contudo, sob forma diversa: a da distinção, que em alguns países se veio a consagrar, entre recursos ordinários e extraordinários, aqueles obstativos do trânsito em julgado, estes utilizáveis contra decisões já revestidas da auctoritas rei iudicatae. Do ponto de vista substancial, os 'recursos extraordinários', em tais sistemas, desempenham função análoga à das ações autônomas de impugnação." (BARBOSA MOREIRA, 2010, p. 231).

115 SOUZA, 2011, pp. 39/40.

${ }^{116}$ BARBOSA MOREIRA, 2010, p. 233; e COUTURE, 1958, p. 350.

${ }^{117}$ AMENDOEIRA JR., 2012, pp. 15/16; CHEIM JORGE, 2011, p. 30; KOZIKOSKI, 2011, p. 48.
} 


\subsection{Diferença entre duplo grau de jurisdição e recurso}

Por fim, apenas para concluir, cumpre apontar brevemente a diferença entre duplo grau de jurisdição e recurso.

Apesar de parte dos doutrinadores e dos operadores do direito confundir os institutos, duplo grau de jurisdição e recurso são diferentes.

É possível que haja duplo grau de jurisdição sem recurso, como no reexame necessário, que pode devolver integralmente a análise da causa a outro órgão julgador independentemente da vontade da parte ${ }^{118}$.

Também é possível se verificar diversos recursos que não efetivam o duplo grau de jurisdição, pois ou limitam o âmbito de devolução, como o recurso especial e o recurso extraordinário $^{119}$, ou não se referem à causa, como os diversos tipos de agravo $^{120}$, ou determinam novo julgamento pelo mesmo órgão julgador, como os embargos de declaração.

Assim, tratar recurso e duplo grau de jurisdição como o mesmo instituto jurídico inevitavelmente levará o jurista a erro, pois não se ateve às características próprias de cada um. Pensar na limitação de recursos não é o mesmo que pensar na limitação do duplo grau de jurisdição, pois é plenamente possível que as decisões interlocutórias não sejam recorríveis, sem que isso viole o duplo grau de jurisdição, por exemplo.

Não obstante, impossível negar que os recursos, pelo menos alguns deles, são as ferramentas apropriadas para levar a efeito o duplo grau de jurisdição ${ }^{121}$. Por meio dos recursos com ampla devolução, como o recurso ordinário constitucional, espécie recursal cuja análise pormenorizada é o objeto desta dissertação, se efetiva o duplo grau de jurisdição.

Daí a relação tão íntima entre duplo grau de jurisdição e recursos, que pode gerar confusão no jurista desavisado, mas que de forma alguma possibilita a interpretação de que se trata do mesmo instituto jurídico processual.

\footnotetext{
118 SOUSA, 2010, p. 51.

${ }^{119}$ LASPRO, 1995, pp. 157/158.

120 TEIXEIRA, 2008, p. 343.

${ }^{121}$ SOUZA, 2011, p. 44.
} 


\section{CLASSIFICAÇÃO DOS RECURSOS EM ORDINÁRIOS E EXTRAORDINÁRIOS - BREVE ANÁLISE CRÍTICA}

Antes de se adentrar no estudo específico do recurso ordinário constitucional, necessário fixar o critério que justifica a classificação das espécies recursais em ordinárias e extraordinárias, para que possa identificar em qual categoria se encontra essa espécie recursal e quais as consequências decorrentes disso.

Cabe apenas apontar que se utiliza as expressões "recursos ordinários" e "recursos extraordinários" sempre em sentido amplo e não nos valeremos dos termos "recursos de fundamentação livre" para substituir "recursos ordinários", e "recursos de fundamentação vinculada" para substituir "recursos extraordinários".

Isso porque há uma diferença de critério em se classificar recursos em ordinários ou extraordinários, de um lado, e de fundamentação livre ou de fundamentação vinculada, de outro.

Recursos de fundamentação livre são aqueles em que se pode alegar qualquer vício da decisão recorrida para que o recurso possa ser conhecido, enquanto o recurso de fundamentação vinculada exige a alegação de um vício específico para que tenha cabimento $^{122}$. Ou seja, o que diferencia uma espécie da outra é a alegação que deve ser deduzida pelo recorrente para que o recurso possa ser conhecido ${ }^{123}$ - qualquer alegação para o cabimento de recurso de fundamentação livre e alegação específica para o cabimento de recurso de fundamentação vinculada.

São exemplos de recursos de fundamentação vinculada o recurso extraordinário, o recurso especial e os embargos de declaração ${ }^{124}$, em que as hipóteses de cabimento são restritas. Os demais (apelação, agravo, recurso ordinário constitucional, etc) são de fundamentação livre, pois qualquer vício pode ser invocado para o cabimento deles.

Não é esse o critério mais adequado, no caso desta dissertação, para distinguir os recursos de competência do Supremo Tribunal Federal e do Superior Tribunal de Justiça, em especial para a análise do recurso ordinário constitucional. Entendemos que o melhor critério é dividir os recursos em ordinários e extraordinários.

\footnotetext{
${ }^{122}$ BARBOSA MOREIRA, 2010, pp. 253/254; CHEIM JORGE, 2011, pp. 46/47; e KOZIKOSKI, 2011, p. 129.

${ }^{123}$ BARBOSA MOREIRA, 2010, pp. 253/254; CHEIM JORGE, 2011, p. 49; e DIDIER JR. e CUNHA, 2010, p. 29.

${ }^{124}$ ASSIS, 2011, p. 59; CHEIM JORGE, 2011, pp. 46/47; DIDIER JR. e CUNHA, 2010, p. 29; e KOZIKOSKI, 2011, p. 129.
} 
Antes de mais nada, deve-se anotar que esse critério se aplica apenas aos recursos em que é necessário haver sucumbência para recorrer. Os embargos de declaração, em que esse requisitos inexiste, são recurso sui generis ${ }^{125}$, não se enquadrando nem entre os recursos ordinários, nem entre os extraordinários.

A doutrina estrangeira não tem um conceito firme sobre o ponto que divide os recursos em ordinários e extraordinários. A doutrina italiana ${ }^{126}$ e a portuguesa ${ }^{127}$ entendem que são ordinários os recursos que são interpostos enquanto ainda não tiver se formado a coisa julgada, sendo extraordinários aqueles interpostos após o trânsito em julgado.

A doutrina brasileira já foi um tanto vacilante nesse tema. Enumeraram-se três possíveis critérios de distinção dos recursos em ordinários ou extraordinários, de acordo com o sempre lembrado magistério de Miguel SEABRA FAGUndes: conforme os seus pressupostos, conforme o seu objeto e conforme a natureza do juízo ad quem ${ }^{128}$.

Apesar de conceituar bem as balizas para o apontamento da categoria em que se enquadravam os recursos, o citado autor adotava o seu terceiro critério ${ }^{129}$ - natureza do órgão ad quem dotado de competência para julgar o recurso -, o que não se mostra correto atualmente.

Tendo em vista a omissão da lei em definir o ponto que separa os recursos entre cada uma das espécies, deve a doutrina valer-se de parâmetro útil, sob pena de total desnecessidade dessa divisão. Assim, pela configuração recursal vigente no nosso ordenamento jurídico, o

\footnotetext{
125 SICA, 2007, pp. 142/143.

${ }^{126}$ MANDRIOLI, 2000, pp. 245/246; REDENTI, 1997, p. 359; e ZANZUCCHI, 1962, p. 174.

${ }^{127}$ FERREIRA, 2000, p. 61.

128 “7. Sob três aspectos é possível formular essa classificação dos recursos: a) segundo os pressupostos de que dependem; b) segundo o objetivo a que visam; e c) segundo a natureza do juízo ad quem.

8. Em face do primeiro critério, são vias ordinárias de recurso as que dependem apenas da existência duma decisão, sendo extraordinárias aquelas que se condicionam a requisitos especiais.

(...)

9. Sob o segundo critério se têm como ordinários os recursos de apelação, embargos de nulidade ou infringentes, agravo e embargos declaratórios, capitulando-se como excepcionais a revista e o recurso extraordinário.

Aqueles levam o litígio ao conhecimento do juízo ad quem, tal como se formulou e desenvolveu, isto é, nos seus diversos aspectos de direito e de fato. Nestes, novo pronunciamento jurisdicional suscitado adstringe-se ao exame de aspectos especiais da relação processual: a divergência de interpretação do direito em tese, na revista, e as questões atinentes à Constituição e às leis e tratados federais, inclusive às concernentes à disparidade de interpretação, no recurso extraordinário.

10. Finalmente, considerada a natureza do juízo para que se recorre, somente o recurso extraordinário reveste cunho excepcional. Enquanto os demais funcionam no âmbito local, ou seja, se contêm no conhecimento das cortes comuns de recurso, que são os tribunais de apelação, aquele devolve a causa a um tribunal extraordinário com jurisdição em todo o país (S. T. Federal) e cujo papel específico é assegurar a supremacia da Constituição e das leis federais, bem como a sua unidade exegética." (SEABRA FAGUNDES, 1946, pp. 10/12).

${ }^{129}$ Idem, p. 12.
} 
entendimento da doutrina italiana e da portuguesa, e o de Miguel SEABRA FAGUNDES, não se mostram interessantes ${ }^{130}$.

A legislação nacional não prevê nenhum recurso que pode ser interposto após a formação da coisa julgada. Dessa forma, adotada a baliza italiana e portuguesa, todos os recursos seriam ordinários, de nada servindo essa distinção ${ }^{131}$. Os ditos "recursos extraordinários" estariam muito mais próximos da nossa ação rescisória, por exemplo.

A natureza do tribunal competente para o julgamento do recurso também não vale como divisor entre as espécies recursais ordinárias e extraordinárias.

Por este critério, todo recurso dirigido aos tribunais superiores - Supremo Tribunal Federal, Superior Tribunal de Justiça, Tribunal Superior do Trabalho, Tribunal Superior Eleitoral e Superior Tribunal Militar - seria extraordinário, enquanto os demais, de competência dos tribunais ordinários, seriam também eles ordinários. Isso faria com que o recurso ordinário constitucional fosse classificado como extraordinário, o que seria uma contradição em termos ${ }^{132}$.

LEONARdo CASTANHO MENDES considera que o que diferencia os recursos extraordinários dos ordinários são os seus requisitos de admissibilidade - os primeiros têm requisitos mais restritos, enquanto os segundos têm requisitos mais amplos - e as suas finalidades - efetuar o duplo grau de jurisdição seria a finalidade dos recursos ordinários e corrigir "vícios gravíssimos" a dos extraordinários ${ }^{133}$.

Esse critério não está correto, pois, conforme já exposto, os requisitos de admissibilidade mais ou menos restritos são o critério de separação dos recursos entre de fundamentação vinculada e de fundamentação livre, respectivamente; e nem todo recurso ordinário visa a efetivar o duplo grau de jurisdição ${ }^{134}$, além do que a expressão "vícios gravíssimos" é muito genérica, não servindo de parâmetro para essa classificação.

Rodolfo de CAMARGo MANCUSO apresenta uma série de diferenças entre os recursos ordinários e os extraordinários. Os recursos extraordinários (i) têm forma mais rígida que os ordinários; (ii) restringem-se a questões de direito, enquanto os ordinários também permitem a discussão de fatos; (iii) são de competência dos tribunais superiores, enquanto os ordinários se dirigem a tribunais inferiores; (iv) não servem apenas e tão somente para solucionar a "injustiça" da decisão, o que pode ser feito por meio dos ordinários; (v) estão vinculados a

\footnotetext{
${ }^{130}$ SILVA e GOMES, 2010, p. 279.

${ }^{131}$ FREITAS CÂMARA, 2008, p. 55.

${ }^{132}$ MARQUES, 2000, p. 29.

${ }^{133}$ MENDES, 2006, pp. 93/95.

${ }^{134}$ Conforme exposto no Capítulo 2 desta dissertação.
} 
pressupostos de cabimento regrados pela Constituição Federal, enquanto os ordinários têm sua regulamentação prevista na legislação infraconstitucional; e (vi) além da sucumbência, exigem mais um requisito, o que não ocorre com os ordinários ${ }^{135}$.

O equívoco dessa classificação é definir muitos parâmetros para distinguir os recursos ordinários dos extraordinários. Forma rígida não é um requisito dos recursos extraordinários, mas sim a forma pela qual seus pressupostos foram interpretados pelos tribunais que detém competência para julgá-los, podendo ocorrer maior ou menor flexibilidade dependendo do julgador, não da espécie recursal. Há recursos ordinários de competência dos tribunais superiores, como o recurso ordinário constitucional e o agravo regimental, o que faz com que o órgão julgador não seja parâmetro válido para essa classificação. Os pressupostos de cabimento do recurso ordinário constitucional também estão previstos na Carga Magna, mas nem por isso ele é um recurso extraordinário em sentido amplo.

ViCENTE GRECO FiLHO entende que os recursos ordinários são aqueles cabíveis no processo comum para a correção de prejuízo sofrido pelo recorrente, enquanto recursos extraordinários também são cabíveis no processo comum, mas estão consagrados em nível constitucional e servem não só para a solução de um prejuízo, mas também para manter a uniformidade interpretativa do ordenamento jurídico federal, constitucional e infraconstitucional $^{136}$.

Esse critério não pode ser aceito integralmente porque o recurso ordinário constitucional, que integra o conjunto dos recursos ordinários em sentido amplo, também é consagrado pela Constituição Federal, e, conforme se verá a seguir, a manutenção da uniformidade do ordenamento jurídico federal é alcançada quando os tribunais superiores julgam qualquer tipo de recurso.

A doutrina majoritária, como, por exemplo, AlEXANDrE FreITAS CÂMARA ${ }^{137}$, Araken de Assis ${ }^{138}$, Flávio Cheim Jorge ${ }^{139}$, José Miguel Garcia Medina e Teresa Arruda Alvim WAMBIER ${ }^{140}$, LuIZ Rodrigues WAMBIER $^{141}$, SANDro Marcelo KOZIKOSKI $^{142}$ e SÉRGIO BERMUDES ${ }^{143}$, entende que o que separa os recursos ordinários dos

\footnotetext{
${ }^{135}$ MANCUSO, 2013, p. 118.

${ }^{136}$ GRECO FILHO, 2012, p. 331.

${ }^{137}$ FREITAS CÂMARA, 2008, pp. 54/55.

${ }^{138}$ ASSIS, 2011, pp. 58/59

${ }^{139}$ CHEIM JORGE, 2011, pp. 45/46.

${ }^{140}$ MEDINA e WAMBIER, 2008, p. 96.

${ }^{141}$ WAMBIER, L., 2008, p. 340.

${ }^{142}$ KOZIKOSKI, 2011, pp. 129/130.

${ }^{143}$ BERMUDES, 1975, p. 34.
} 
extraordinários é o fato destes tratarem precipuamente ${ }^{144}$ do direito objetivo, enquanto os primeiros versariam precipuamente sobre direito subjetivo.

Esse modo de conceituar os recursos não é dos mais claros, gerando dúvidas do que seria direito subjetivo e direito objetivo.

Um dos requisitos de admissibilidade comum a todos os recursos é o interesse recursal, um liame subjetivo entre a decisão recorrida e a possibilidade do recorrente obter tutela jurisdicional mais favorável ${ }^{145}$. Esse requisito seria mitigado ou atenuado nos recursos extraordinários porque se estaria tutelando direito objetivo? Não parece ser assim.

O critério de divisão dos recursos entre ordinários e extraordinários utilizado por AlCides de MENDONÇA Lima ${ }^{146}$ e por Humberto THEOdORO JÚNiOR ${ }^{147}$ é o que se considera correto. Entendem que o que separa uma espécie de recursos da outra é o âmbito da devolutividade que o recurso proporciona ao juízo ad quem. Os recursos ordinários podem devolver toda a matéria versada na causa, enquanto os recursos extraordinários possibilitam a devolução restrita a questões de direito. A doutrina francesa também adotada essa baliza para realizar essa classificação dos recursos ${ }^{148}$.

Explica-se.

O parâmetro adotado pela doutrina majoritária - predomínio da tutela do direito objetivo pela via dos recursos extraordinários e da tutela do direito subjetivo pela via dos ordinários - não é adequado, porque o que faz com que o direito objetivo tenha maior ou menor tutela não é a espécie recursal pela qual ele é analisado, mas sim o tribunal que o julga.

O direito subjetivo é a mola propulsora de qualquer recurso ${ }^{149}$, não existindo um recurso que vise única e exclusivamente a proteger a lei ${ }^{150}$. Recursos não servem apenas para

\footnotetext{
${ }^{144}$ Chega-se até a dizer exclusivamente em algumas passagens (ASSIS, 2011, p. 59; e CHEIM JORGE, 2011, p. $45)$.

145 "60. Deve aferir-se pelo prisma prático a ocorrência da utilidade, proveito ou vantagem cuja possibilidade configura o interesse em recorrer. A razão de ser do processo não consiste em proporcionar ocasião para o debate de teses, ainda que relevantíssimas do ponto-de-vista teórico, mas sem conseqüências concretas para a disciplina do caso levado à apreciação do juiz. Nem pode a atividade do aparelho judiciário do Estado servir de mero instrumento para a solução de questões acadêmicas. (...)" (BARBOSA MOREIRA, 1968, pp. 76/77).

146 “....) Para caracterizar a natureza do recurso, se ordinário ou se extraordinário (empregado esse termo em sentido amplo), não importa que o mesmo seja pertinente, tão-somente, a determinadas decisões como, $v . g$., os agravos (cujos casos são expressos em lei), ou embargos (cujos pressupostos, na espécie mais importante, isso é, de nulidade ou infringentes, são de ordem puramente material, saber se o acórdão embargado foi proferido, $v . g$., em apelação e se houve, ou não, unanimidade). O essencial é fixar o poder da instância superior sobre a decisão recorrida: Se a lei permite o conhecimento de questões de fato e de direito, sem qualquer limitação, o recurso, que enseja pronunciamento do Juízo ad quem, é ordinário; se, porém, restringe este conhecimento somente a questões de direito - o de revista e o extraordinário propriamente dito - é extraordinário. (...)" (MENDONÇA LIMA, 1958, pp. 54/55).

${ }^{147}$ THEODORO JÚNIOR, 1993, pp. 07/08.

${ }^{148}$ JAUFFRET e NORMAND, 1984, p. 164; e VINCENT, 1974, p. 706.

${ }^{149}$ KOZIKOSKI, 2011, pp. 129/130.
} 
discutir teses acadêmicas ${ }^{151}$ ou para prestar consultas hipotéticas sobre a melhor interpretação da norma ${ }^{152}$. Servem para atender a interesse do recorrente, o que faz com que o direito subjetivo dele sempre esteja presente ${ }^{153}$.

Quando um tribunal superior, órgão responsável pela harmonização da interpretação jurisprudencial sobre direito federal ${ }^{154}$, julga um recurso - qualquer recurso - dá a última palavra sobre a aplicação do direito naquele caso, o que serve de precedente, vinculante ou não, para a interpretação daquela mesma norma em outros julgamentos pelos diversos tribunais brasileiros ${ }^{155}$.

No Brasil, essa unificação da interpretação ocorre com maior frequência quando o Supremo Tribunal Federal julga recursos extraordinários e quando o Superior Tribunal de Justiça julga recursos especiais ${ }^{156}$. Mas isso se dá porque esses recursos são de fundamentação

${ }^{150}$ Neste ponto, há divergência doutrinária. JOSÉ CARLOS BARBOSA MOREIRA (2010, p. 585) entende que qualquer recurso interposto pelo Ministério Público, quando atua como custos legis tutela apenas a lei, enquanto ARAKEN DE ASSIS (2011, p. 59) discorda, por entender que o interesse específico daquela demanda sempre é tutelado quando o parquet recorre, ainda que como custos legis.

151 “Todavia, embora com devolutividade limitada, já que destinado, fundamentalmente, a assegurar a inteireza e a uniformidade do direito federal infraconstitucional, o recurso especial não é uma via meramente consultiva, nem um palco de desfile de teses meramente acadêmicas. Também na instância extraordinária o Tribunal está vinculado a uma causa e, portanto, a uma situação em espécie (Súmula 456 do STF; Art. 257 do RISTJ)." (STJ, REsp no 885.152/RS, Rel. Min. Teori Albino Zavascki, $1^{\text {a }}$ Turma, j. 06/02/20007)

${ }^{152}$ FONSECA, 2012, p. 50.

${ }^{153}$ Idem, p. 47.

${ }^{154}$ Idem, pp. $25 / 26$.

155 “7. Uniformização da jurisprudência e decisões-quadro. Sendo uma das funções dos tribunais superiores uniformizar o entendimento da CF (STF) e da lei federal do País (STJ e TST), toda decisão tomada pelas cortes superiores em casos individuais projeta o entendimento no tribunal, atuando como que paradigma para casos idênticos futuros. A relevância das decisões dos tribunais superiores em lides individuais, portanto, não está apenas na sua aplicação ao caso concreto, como atuação da verdadeira atividade substitutiva da jurisdição e como fator de implementação da paz social. Sua relevância transcende à situação individual está no quadro da fundamentação do acórdão (im Rahmen der Urteilsbegründung) (Larenz. Methodenlehre6, n. IV, 4, b, p. 357 e n. $\mathrm{V}, 5$, p. 429), fundamentos esses que se aplicarão aos casos concretos futuros que serão examinados por tribunal superior ou por qualquer outro órgão do Poder Judiciário. Daí podermos nominar de decisões-quadro os pronunciamentos do STF, STJ, TST, TSE e STM a respeito das matérias que são de sua competência constitucional." (NERY JÚNIOR e NERY, 2009, p. 476).

${ }^{156}$ Fez-se uma breve análise dos precedentes que embasaram a edição das 31 (trinta e uma) Súmulas Vinculantes e das 20 (vinte) últimas Súmulas editadas pelo Supremo Tribunal Federal e pelo Superior Tribunal de Justiça, até 08 de fevereiro de 2013.

Dos 547 (quinhentos e quarenta e sete) acórdãos que deram base às Súmulas, 210 (duzentos e dez) foram proferidos no julgamento de recursos extraordinários em sentido amplo (recurso extraordinário, recurso especial e embargos de divergência), o que equivale a 38,4\% (trinta e oito vírgula quatro por cento) do total; 83 (oitenta e três) foram proferidos no julgamento de agravos regimentais interpostos contra decisões monocráticas que julgaram recursos extraordinários em sentido amplo, equivalente a 15,2\% (quinze vírgula dois por cento) dos precedentes; 181 (cento e oitenta e um) foram proferidos em ações de competência originária (ação direta de inconstitucionalidade, ação direta de constitucionalidade, mandado de segurança, habeas corpus, cautelares, conflitos de competência e de jurisdição, reclamação e homologação de sentença estrangeira) ou em agravos regimentais ou embargos de declaração apresentados nesses processos, o que equivale a 33,1\% (trinta e três vírgula um por cento) do total; e 73 (setenta e três) foram prolatados quando do julgamento de recursos ordinários em sentido amplo (recurso ordinário constitucional, agravo de instrumento contra decisão que não admite recurso extraordinário ou especial e agravo de instrumento em ação de competência originária), o que equivale a $13,3 \%$ (treze vírgula três por cento) dos precedentes. 
vinculada e a vinculação da fundamentação se refere, sempre, a questões de direito, nunca a questões de fato ${ }^{157}$. Além do que essas espécies recursais representam o maior volume de trabalho dessas cortes ${ }^{158}$.

Não é incomum que acórdãos proferidos em ações de competência originária ou em julgamento de recurso ordinário constitucional sirvam de precedentes para a edição de súmulas pelo Supremo Tribunal Federal e pelo Superior Tribunal de Justiça ${ }^{159}$, o que evidencia que o "predomínio do direito objetivo" também acontece quando se julga esses casos. Vale lembrar que o agravo regimental é um recurso ordinário. Então, atendo-se ao rigorismo técnico-processual, quando um agravo regimental interposto contra decisão monocrática que julga recurso extraordinário ou especial é provido, faz-se a chamada análise predominante do direito objetivo no julgamento de recurso ordinário em sentido amplo.

Em se tratando de direito estadual, distrital ou municipal, a harmonização da interpretação jurisprudencial da norma, ou função nomofilática ${ }^{160}$, é exercida apenas e tão somente pelos Tribunais de Justiça dos Estados e do Distrito Federal, cortes essas que apenas têm competência para julgar recursos ordinários. Em nada se diferencia essa função nomofilática do julgamento daquela exercida pelos tribunais de sobreposição, sendo diferente apenas o ente federativo que elaborou a norma jurídica.

No julgamento de recurso extraordinário e de recurso especial, sendo positivo o exame de admissibilidade e se verificando a violação à norma federal, constitucional ou infraconstitucional, respectivamente, o tribunal deve passar ao exame da causa, dentro de certas limitações ${ }^{161}$. O Supremo Tribunal Federal e o Superior Tribunal de Justiça são cortes

Assim, somando os julgamentos de recursos extraordinários em sentido amplo e dos agravo regimentais interpostos nesses recursos, verifica-se que eles equivalem a 53,6\% (cinquenta e três vírgula seis por cento) do total, pouco mais da metade.

${ }^{157}$ FREITAS CÂMARA, 2008, p. 55; e WAMBIER, T., 2008, p. 245.

${ }^{158}$ Nos anos de 2010, 2011 e 2012 o Supremo Tribunal Federal julgou 262.828 (duzentos e vinte e dois mil oitocentos e vinte e oito) casos, sendo 111.077 (cento e onze mil e setenta e sete) recursos extraordinários e agravos regimentais interpostos em recursos extraordinários, ou seja, 42,3\% (quarenta e dois vírgula três por cento) do total. (Disponível em: <file://C:/Users/Jose\%20Eugenio/Documents/Mestrado/Disserta\%C3\%A7\%C3\%A3o/Pesquisa/Pesquisa\%20po r\%20Classe $\% 20 \% 20 \% 20 \% 20$ STF $\% 20-\% 20$ Supremo $\% 20$ Tribunal\%20Federal_files/pesquisaClasse.htm>.

Acesso em: 08 fev. 2013).

Não é possível fazer uma análise precisa dos julgamentos do Superior Tribunal de Justiça porque o relatório estatístico elaborado pela corte não aponta em que casos foram interpostos agravos regimentais, o que torna impossível saber quantos desses recursos foram interpostos contra decisões monocráticas que analisaram recursos especiais. (Disponível em: $<$ http://www.stj.gov.br/webstj/Processo/Boletim/?vPortalAreaPai=183\&vPortalArea=584>. Acesso em: 08 fev. 2013).

${ }^{159}$ Vide nota 156.

160 A palavra nomofilática vem do grego e é a junção das palavras nomos, que significa lei, e phylásso, que significa guarda. Ou seja, significa a qualidade de proteger a norma jurídica (FONSECA, 2012, p. 40).

${ }^{161}$ FONSECA, 2012, p. 47; e MANCUSO, 2013, pp. 144/145 e 148/149. 
de revisão, não cortes de cassação ${ }^{162}$, tendo o dever de proferir decisão que analise a causa e que substituirá o acórdão recorrido.

Assim, direito objetivo e direito subjetivo estão em um mesmo patamar hierárquico nesses recursos ${ }^{163}$, o que afasta o critério adotado pela doutrina majoritária para distinguir recursos entre ordinários e extraordinários.

Critério válido para separar os recursos em ordinários e extraordinários é o seu âmbito de devolutividade. Enquanto nos recursos ordinários a devolução é irrestrita, nos extraordinários só se pode examinar questões de direito, seja por error in judicando, seja por error in procedendo.

Dessa forma, entre os recursos previstos no Código de Processo Civil, são recursos ordinários a apelação, o agravo, os embargos infringentes e o recurso ordinário constitucional. São extraordinários o recurso extraordinário, em sentido estrito, o recurso especial e os embargos de divergência ${ }^{164}$. Os embargos de declaração são recurso sui generis, conforme ressalvado no início deste capítulo.

É possível concluir que todo recurso ordinário em sentido amplo também é um recurso de fundamentação livre, e vice-versa. Se o âmbito de devolutividade do recurso é ilimitado, qualquer alegação pode fundamentá-lo e se qualquer tipo de alegação pode ser deduzida pelo recorrente para que o recurso tenha cabimento, todos os argumentos apresentados deveram ser apreciados pelo juízo ad quem, desde que necessários para atender o interesse do recorrente $^{165}$.

Todo recurso extraordinário, em sentido amplo, é de fundamentação vinculada, mas a recíproca não é verdadeira. Se a vinculação da fundamentação for apenas questão de direito, esse recurso será extraordinário. Mas se o critério for outro - como a ocorrência de omissão, contradição ou obscuridade, como no caso dos embargos de declaração - o recurso não será extraordinário. Também se pode imaginar um recurso que limita a análise do juízo ad quem aos fatos, à apreciação da prova e fixação dos parâmetros fáticos daquela causa, devendo o juízo a quo, com base naquela moldura, aplicar o direito. Esse recurso será de fundamentação vinculada, mas não será extraordinário, pois não permitirá apenas e tão somente o exame de questões de direito.

\footnotetext{
${ }^{162}$ FONSECA, 2012, pp. 49/51.

${ }^{163}$ Com predomínio do direito objetivo no exame de admissibilidade e no juízo rescindendo do acórdão recorrido e com maior força do direito subjetivo no juízo rescisório (FONSECA, 2012, pp. 47/48)

${ }^{164}$ CHEIM JORGE, 2011, p. 45.

${ }^{165}$ Se basta o acolhimento de uma alegação para que o interesse do recorrente seja integralmente atendido, não é necessário o exame de todas as outras. Por exemplo: o recorrente alega a ocorrência de prescrição e a inexigibilidade do crédito cobrado, por quitação. Acolhendo-se a alegação de prescrição, desnecessário tecer qualquer consideração a respeito da eventual quitação.
} 
Como o recurso ordinário constitucional é um recurso ordinário em sentido amplo, isso significa que os tribunais superiores, ao julgá-lo, podem e devem analisar questões de fato, o que é uma excepcionalidade, tanto em razão dos demais processos de competência desses tribunais, quanto em comparação com as funções de cortes superiores estrangeiras.

É recurso que, quando interposto contra sentença ou acórdão que decide a causa, efetiva o duplo grau de jurisdição, sendo também excepcional aos tribunais superiores terem a missão de levar esse princípio constitucional a efeito.

Essa excepcionalidade do recurso ordinário constitucional decorre de origens históricas, que serão melhor analisadas a seguir. 


\title{
4 RECURSO ORDINÁRIO CONSTITUCIONAL - EVOLUÇÃO HISTÓRICA
}

\section{$\underline{4.1 \quad \text { Tutela de direitos fundamentais - Previsão constitucional }}$}

São duas as razões que originaram a criação do recurso ordinário constitucional: (i) a tutela de direitos fundamentais, em especial o direito de ir, vir e ficar; e (ii) a ausência de uma Justiça Federal bem aparelhada nos primórdios da República.

Vale citar a lição de ARAKEN DE ASSIS neste ponto:

\begin{abstract}
Ao contrário do que ordinariamente se entende, o recurso ordinário surgiu na esteira da instituição da Justiça Federal, composta do STF e de juízes de primeiro grau, como meio de impugnação dos atos decisórios destes para aquele. Transformou-se, na Lei 221/94, nos recursos 'ordinários' previstos na lei processual para recorrer das sentenças definitivas e das decisões. O simples exame dos casos originais de cabimento revela que, na origem, tratou-se de expediente transitório, suprindo a falta de uma corte de segundo grau na Justiça Federal. Além disso, o recurso serviu para sobre valorizar, bem de acordo com os embates políticos daquela conjuntura histórica, o direito fundamental de habeas corpus. A defesa da liberdade constituía bem por demais precioso para confiá-la a órgãos de hierarquia menor que o STF. Encarregou-se a Corte Constitucional da última palavra quanto ao direito de ir, vir e ficar. O fato representa exemplo de insigne pioneirismo na chamada jurisdição constitucional da liberdade. ${ }^{166}$
\end{abstract}

Hoje, mais de cem anos após o advento da primeira Constituição Republicana e com o aparelhamento da Justiça Federal, perdeu-se uma das funções originárias do recurso ordinário constitucional. Contudo, a sua função de mecanismo processual de defesa de direitos fundamentais não só foi mantida, como ampliada.

O recurso ordinário constitucional guarda grande afinidade com as ações constitucionais - habeas corpus, mandado de segurança ${ }^{167}$, mandado de injunção e habeas data - servindo como meio processual mais abrangente que os recursos extraordinários em

\footnotetext{
${ }^{166}$ ASSIS, 2008, p.72.

167 “Assim é que o Recurso Ordinário constitucional, enquanto derivação da ação de mandado de segurança, mantém com ele esta estreita afinidade, porque não dizer genética, porquanto, sem serem um único ente, associam-se harmoniosamente no cumprimento de um mesmo mister: dotar o cidadão, e a sociedade civil organizada, de um mecanismo ágil e eficaz contra violações - ou ameaças - a direitos ou interesses individuais e coletivos." (SIQUEIRA, 2001, p. 34).
} 
sentido amplo para levar aos tribunais superiores a análise de possíveis violações a direitos fundamentais $^{168}$.

Conforme exposto acima, como o recurso ordinário constitucional permite reexame muito mais amplo do que o possibilitado pelos recursos extraordinários em sentido amplo, ele garante o duplo grau de jurisdição em casos especiais, ou seja, em que foi denegada ação constitucional ajuizada pelo cidadão em face do Estado $^{169}$, o que não ocorre quando a ação é julgada procedente.

A previsão constitucional desse recurso também fortalece a defesa dos direitos fundamentais, pois será necessária emenda constitucional para a revogação desse meio de impugnação das decisões judiciárias. Aliás, esse é um dos principais pontos que serve para justificar a autonomia do recurso ordinário constitucional.

A defesa de direitos fundamentais sempre foi o principal fator que justificou a existência do recurso ordinário constitucional. A comissão de reforma da Constituição Federal de 1946, vigente durante período de liberdade democrática, após a Era Vargas e antes da Ditadura Militar, não desejava eliminar o recurso, mas apenas cogitou eliminar o seu cabimento em mandado de segurança ${ }^{170}$. Da mesma forma, não se verifica nos debates da Assembleia Constituinte de 1987 o desejo de eliminar o recurso, mas sim de expandir ainda mais suas hipóteses de cabimento, incluindo a ação popular, em casos ainda mais amplos do que o texto constitucional aprovado ${ }^{171}$.

\footnotetext{
${ }^{168}$ SILVA, E., 1978, p. 94.

${ }^{169}$ THEODORO JÚNIOR, 1993, p. 08.

170 "A tradição e o zelo de assegurar total imparcialidade pela hierarquia do Supremo, porém, tem influído na subsistência do recurso ordinário constitucional, desdobrado em recursos normais, como ocorre, agora, com o atual Código de Processo Civil. A Comissão de Juristas incumbida pelo Ministério da Justiça de apresentar projeto de 'Reforma Constitucional', ao tempo da Constituição Federal de 1946, antes da Revolução de 1964, sugeriu, apenas, a supressão do cabimento do recurso ordinário quando denegados mandados de segurança. Os demais casos deveriam permanecer pelos seguintes argumentos adaptados ao texto ora em vigor (art. 119, n. III, $a, b$, e $c$ ): os da alínea $a$ têm repercussão internacional; os da $b$ costumam despertar paixões, quando não há punição, sendo os dois de pouca ocorrência, não prejudicando, assim, o serviço do Supremo; e os da $c$, para maior segurança individual, justificando a interferência do Supremo, com cujo altíssimo órgão o habeas corpus se identificou ao longo da História." (MENDONÇA LIMA, 1976, pp. 223/224).

${ }^{171} \mathrm{O}$ recurso ordinário constitucional foi objeto de discussão da $6^{\mathrm{a}}$ Reunião Extraordinária da Subcomissão do Poder Judiciário e do Ministério Público da Assembleia Constituinte de 1987, realizada em 27 de abril de 1987. Nesse reunião, que teve a participação de juristas convidados, dois deles se manifestaram pelo manutenção e ampliação das hipóteses de cabimento do recurso ordinário constitucional, sempre com base na defesa dos direitos fundamentais.

FÁBIO KONDER COMPARATO defendeu o “(...) restabelecimento do recurso ordinário ao Supremo Tribunal Federal (ou o tribunal que o substitua) em matéria de habeas-corpus e mandado de segurança, e a criação desse recurso nas aç̃es populares. O Supremo Tribunal Federal, órgão de cúpula do Poder Judiciário federal, deve ser descongestionado em relação a recursos extraordinários, mas não pode deixar de exercer a função eminente de proteção dos liberados individuais, sobretudo quando se depara, como ocorre freqüentemente, com a prepotência dos poderes locais. O recurso ordinário em habeas-corpus e mandato de segurança foi suprimido pela Constituição vigente de modo estranho - sem dúvida sob a influência de um Poder que não tinha muito compromisso com a defesa dos direitos humanos - em prejuízo da proteção desses mesmos direitos.
} 
O exame da evolução da disciplina constitucional e infraconstitucional do recurso ordinário constitucional permite uma melhor compreensão das razões que ensejaram o seu advento e também dos motivos que justificam a permanência da sua previsão no nosso ordenamento jurídico.

\subsection{Evolução do tratamento constitucional}

A Constituição Federal de 1891 já disciplinava um recurso ao Supremo Tribunal Federal - única corte superior à época -, ainda que não se utilizasse da expressão "recurso ordinário". Referido recurso era cabível em casos de (i) julgamento de processo de competência da Justiça Federal; (ii) em casos de competência da Justiça Estadual, quando se trata de (ii.a) habeas corpus ou (ii.b) espólio de estrangeiro, sem que houvesse tratamento da matéria em convenção ou tratado internacional ${ }^{172}$.

Deve-se ressaltar que o instituto jurídico do habeas corpus tinha significado muito mais amplo do que tem hoje. Servia não só para os casos de restrição ao direito de ir, vir e ficar, mas também para as hipóteses em que seria cabível, atualmente, o mandado de

(...) Tribunal Superior ou Supremo da justiça Federal em matéria de ação popular, porque os casos de ação popular mais clamorosos, que dizem respeito à destruição dos bens comuns do povo são, em geral, mal julgados pelos tribunais locais, tendo em vista a enorme pressão que estes sofrem do Poder Executivo." (grifos nossos, p. 138).

RAUl MACHADO HoRTA, por sua vez, se manifestou no sentido de que "O Supremo, de acordo com esta proposta de criação do Superior Tribunal de Justiça, passaria a exercer o chamado contencioso da constitucionalidade, quando a decisão recorrida contrariar dispositivo da Constituição Federal, declarar a inconstitucionalidade de tratado ou lei federal e julgar válida lei ou ato do governo local, contestado em face da Constituição. O Supremo conservaria a competência originária de processo e julgamento para as questões dessa natureza e a competência de julgamento de recurso ordinário, de habeas-corpus e de mandato (sic) de segurança, quando denegatória a decisão.” (p. 141)

Já o constituinte PAES LANDIM, por fim, disse que “(...) já temeria um pouco a criação do Tribunal Superior de Justiça. Acho que os Estados deveriam remeter as controvérsias de Direito Privado e esses conflitos de entendimento de vários tribunais estaduais diretamente ao Supremo Tribunal Federal. Aí eu perguntaria, dentro do bojo da colocacão de $V$. Ex. ${ }^{a}$ se não seria possível talvez, com esse desafogo que a criacão do Tribunal Superior Federal e dos tribunais de recursos dos Estados daria ao Supremo Tribunal Federal, 0 restabelecimento do recurso ordinário, que, aliás, está no projeto do Prof. Fábio Conder (sic) Comparato, que proporcionaria inclusive a acão popular direta ao Supremo Tribunal Federal, com aquele resguardo o princípio constitucional de defesa dos interesses maiores da Constituicão - preservando valores da sociedade brasileira com uma ação popular direta ao Supremo Tribunal Federal. Diante da preocupação do eminente ministro Paulo Brossard, de que talvez a criação desses tribunais, o restabelecimento desse recurso ordinário e sobretudo a ação direta de inconstitucionalidade poderiam aumentar mais ainda os trabalhos do Supremo Tribunal Federal, acho que os mecanismos procedimentais que o Supremo Tribunal Federal criou - a súmula e a chamada arguição de relevância -, esses instrumentos procedimentais ajudariam a equilibrar o papel do nosso Supremo Tribunal Federal, essa grande contribuição de Rui Barbosa. Porque entendo que é um dever nosso, de quem luta pela estabilidade democrática do nosso País, tentar cada vez mais aumentar o seu poder e criar condicões cada vez mais do seu papel proeminente na defesa das instituicões democráticas

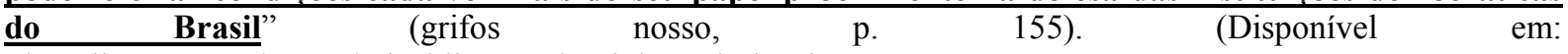
$<$ http://www.senado.gov.br/publicacoes/anais/constituinte/3c\% $\% 20$ -

$\% 20$ SUBCOMISS $\%$ C3\%83O\%20DO\%20PODER\%20JUDICI\%C3\%81RIO.pdf>. Acesso em: 30 jan. 2013).

172 MENDONÇA, 2006, p. 595. 
segurança ${ }^{173}$. Porém, com a promulgação da Emenda Constitucional de 1926, o seu âmbito de aplicação foi restringido às hipóteses que vigoram até hoje ${ }^{174}$.

Foi a Constituição Federal de 1934 a primeira a utilizar o termo "recurso ordinário" em seu texto ${ }^{175}$, que vem se repetindo até a vigente Carta Magna. O recurso poderia ser interposto contra decisões (i) proferidas em causas federais; (ii) proferidas pelo Tribunal Superior da Justiça Eleitoral; e (iii) denegatórias de habeas corpus, proferidas em única ou última instância ${ }^{176}$.

Já se percebe a aproximação entre as atuais hipóteses de cabimento do recurso ordinário constitucional e as previstas na Constituição Federal de 1934, que já limita o cabimento do recurso às decisões denegatórias de habeas corpus, de última ou única instância.

No entanto, a Constituição Federal de 1934 teve curta vigência, sendo substituída pela Carta de 1937. Referida norma extinguiu a Justiça Federal e previu o cabimento do recurso ordinário constitucional contra decisões (i) lançadas em causas envolvendo a União e (ii) de última ou única instância denegatória de habeas corpus ${ }^{177}$.

A Constituição Federal de 1946 foi a que mais se assemelhou à atual disciplina dos casos em que é cabível o recurso ordinário constitucional. Retomando a linha de maior proteção aos direitos do cidadão e restabelecendo a Justiça Federal, essa Carta Magna previa que essa espécie recursal teria cabimento (i) contra decisão denegatória de habeas corpus e de mandado de segurança, proferida em última instância; (ii) em causas que envolvessem tratado ou contrato firmado entre a União e Estado estrangeiro; (iii) em causas em que fossem partes Estado estrangeiro e pessoa domiciliada no Brasil; (iv) em causas que tratassem de crime político e (v) em causas que envolvessem direito eleitoral constitucional ${ }^{178}$.

Foi esse o primeiro diploma constitucional a prever expressamente o cabimento de recurso ordinário constitucional contra decisão proferida em sede de mandado de segurança, o primeiro a dispor que o recurso seria cabível em causas envolvendo crime político e o pioneiro a tratar de modo detido o cabimento dessa espécie recursal nas chamadas causas internacionais.

\footnotetext{
173 "O mandado de segurança era então desconhecido das instituições jurídicas brasileiras, tendo o Supremo Tribunal Federal, em notável interpretação construtiva, encontrado um sucedâneo para aquele remédio processual, através do 'habeas corpus'. Assim, os recursos de decisões proferidas em 'habeas corpus' podiam abranger, também, matéria civil.” (AMERICANO, 1965, p. 71).

${ }^{174}$ MENDONÇA, 2006, p. 596.

175 RODRIGUES, 1997, p. 85.

${ }^{176}$ ASSIS, 2008, p. 69.

${ }^{177}$ AMERICANO, 1965, p. 72.

${ }^{178}$ MENDONÇA, 2006, p. 597.
} 
O Ato Institucional $n^{\circ}$ 02/1965 e a Emenda Constitucional $n^{\circ}$ 01/1965 eliminaram as causas internacionais como hipótese de cabimento do recurso ordinário constitucional, transferindo-as para a competência da Justiça Federal ${ }^{179}$.

A curta Constituição Federal de 1967 tentou retomar a previsão da Carta Magna anterior, porém a Emenda Constitucional $n^{\circ}$ 01/1969 limitou os casos de cabimento do recurso ordinário constitucional (i) à decisão denegatória de habeas corpus, proferida em última ou única instância; e (ii) à decisão proferida em causa internacional, entendida como aquela que tem como partes Estado estrangeiro ou organismo internacional de um lado, e pessoa residente ou domiciliada no Brasil ou Município brasileiro do outro ${ }^{180}$.

Por fim, a vigente Constituição Federal de 1988 aumentou bastante as hipóteses de cabimento do recurso ordinário constitucional, diferenciando-o quanto ao tribunal superior competente para o seu julgamento - Supremo Tribunal Federal (artigo 102, II, 'a' e 'b') ou Superior Tribunal de Justiça (artigo 105, II, 'a', 'b' e 'c') ${ }^{181}$. O exame pormenorizado dessas hipóteses de cabimento será feito em item subsequente (Capítulo 5).

Percebe-se que a disciplina constitucional do recurso ordinário constitucional sofreu alterações conforme foram se estabelecendo governos mais ou menos democráticos, sendo sempre mais abrangente quando a defesa dos interesses individuais era um valor mais caro ao Estado.

A Constituição Federal de 1891, primeira do Brasil República, não teve maiores preocupações com o tratamento do instituto, que servia muito mais como uma solução transitória enquanto a Justiça Federal não era propriamente disciplinada. Todavia, não deixou de prever expressamente a existência de um recurso a uma Corte Superior quando se julgava habeas corpus.

A Carta Magna de 1934, que foi promulgada durante a Era Vargas, após a Revolução Constitucionalista de 1932, continuou com a preocupação de fazer com que o recurso ordinário constitucional pudesse ser usado na falta de um tribunal federal, mas já se mostra mais preocupada com a defesa dos interesses do indivíduo, pois restringe o cabimento do recurso às decisões denegatórias de habeas corpus.

\footnotetext{
${ }^{179}$ ASSIS, 2008, pp. 69/70.

${ }^{180}$ Idem, p. 70.

181 “A Constituição da República de 1988, reflexo do incondicional esforço pela instituição do Estado Democrático de Direito, resgatou o instituto do mandado de segurança - como instrumento idôneo à proteção de direito líquido e certo não amparado por habeas corpus ou habeas data - e viabilizou o cabimento do recurso ordinário em face das decisões proferidas pelos Tribunais Superiores no âmbito do referido remédio constitucional. O texto constitucional distribuiu entre o Supremo Tribunal Federal e Superior Tribunal de Justiça a competência para julgamento do recurso - decorrência lógica da criação da Corte Superior e absorção, por esta, de competências até então atribuídas exclusivamente à Corte Suprema.” (DIDIER JR. e CUNHA, 2010, p. 598).
} 
É possível verificar que, quando se iniciaram governos ditatoriais, o recurso ordinário constitucional sofreu restrições no seu âmbito de aplicabilidade. Foi o que ocorreu com a Constituição Federal de $1937^{182}$, que deu início ao Estado Novo, e com a Emenda Constitucional $n^{\circ}$ 01/1969, que restringiu ainda mais os direitos do cidadão durante a Ditadura Militar.

Em ambos os casos a defesa dos interesses individuais foi deixada em segundo plano, mantendo-se apenas o cabimento do recurso contra decisão denegatória de habeas corpus, proferida em única ou última instância. No primeiro caso, o recurso ordinário constitucional voltou a ser um amparo recursal na ausência de Justiça Federal; e, no segundo, serviu apenas em casos absolutamente excepcionais de causas internacionais.

Por outro lado, quando estamos diante de Constituições Federais que surgiram em tempo de abertura democrática, como as de 1946 - no fim da 2a Guerra Mundial e da Era Vargas - e a vigente de 1988 - com o término da Ditadura Militar -, há um alargamento das previsões de cabimento do recurso ordinário constitucional, sempre com o viés de proteção do cidadão contra eventuais abusos praticados pelo Estado.

Feito este estudo sobre o tratamento constitucional desta espécie de recurso, resta a análise do instituto sobre o ponto de vista infraconstitucional.

\subsection{Legislação infraconstitucional}

O recurso ordinário constitucional só foi disciplinado por lei ordinária a partir do advento da Lei no 8.038/1990, a chamada "Lei dos Recursos", que revogou os artigos 539 a 546 do Código de Processo Civil (artigo 44), que tratavam dos recursos perante o Supremo Tribunal Federal e o Superior Tribunal de Justiça. Nem o Regulamento $n^{\circ} 737 / 1850$, nem o Código de Processo Civil de 1939 (Decreto-Lei n ${ }^{\circ}$ 1.608/1939), nem o Código de Processo Civil vigente (Lei $\mathrm{n}^{\mathrm{o}} 5.869 / 1973$ ), em seu texto original, tratavam do recurso ordinário constitucional como espécie recursal autônoma.

Em sua redação original, o Anteprojeto de Código de Processo Civil, elaborado por ALFREDO BUZAID, previa o recurso ordinário constitucional como espécie recursal autônoma. Previa que o processamento e o julgamento do recurso ordinário constitucional seriam regulados pelo Regimento Interno do Supremo Tribunal Federal (artigo 560 ${ }^{183}$ ), mas também

\footnotetext{
182 ROENICK, 1999, p. 152.

${ }^{183}$ Art. 560. O recurso ordinário e o recurso extraordinário (livro I, título X, capítulos IV e V) serão processados e julgados no Supremo Tribunal Federal, de acordo com o seu regimento interno.
} 
definia suas hipóteses de cabimento - decisão denegatória de mandado de segurança proferida em última ou única instância (artigo $583^{184}$ ); seu prazo - 15 (quinze) dias - e o órgão do juízo a quo competente para seu exame - Presidente do Tribunal que prolatou a decisão - (artigo $584^{185}$ ); que deveria ser feito exame de admissibilidade pelo juízo a quo e o prazo de resposta - também 15 (quinze) dias - (artigo $585^{186}$ ); prazo para recolhimento do preparo recursal - 15 (quinze) dias após a apresentação da resposta pelo recorrido ${ }^{187}$ (artigo $586^{188}$ ); e que, se negado seguimento ao recurso pelo juízo a quo, o recorrente poderia interpor agravo de instrumento dirigido ao Supremo Tribunal Federal no prazo de 15 (quinze) dias (artigo $\left.587^{189}\right)$.

Porém, esses dispositivos legais não foram mantidos na lei aprovada pelo Congresso Nacional, sendo que a disciplina vigente atualmente sobre o recurso ordinário constitucional, como se verá a seguir, é muito menos detalhada do que essa do Anteprojeto do Código de Processo Civil de 1973. Se a lei tivesse sido aprovada na redação pensada por ALFREDO BUZAID, talvez não houvesse tantas dúvidas e controvérsias doutrinárias e jurisprudenciais sobre o procedimento aplicável ao recurso ordinário constitucional - matéria analisada pormenorizadamente no Capítulo 6 desta dissertação.

Antes do advento da Lei $\mathrm{n}^{\circ} 8.038 / 1990$, apenas o Regimento Interno do Supremo Tribunal Federal, e posteriormente o Regimento Interno do Superior Tribunal de Justiça, o regulavam.

O primeiro Regimento Interno do Supremo Tribunal Federal, datado de 1891, o fazia nos artigos 92 a $94^{190}$, mas ainda sob a rubrica "Das Appellações", pois o recurso ordinário constitucional ainda não era assim chamado na vigência da primeira Constituição Federal

\footnotetext{
${ }^{184}$ Art. 583. Da decisão denegatória de mandado de segurança, proferida em única ou última instância, por Tribunal da União, dos Estados, do Distrito Federal e dos Territórios, cabe recurso ordinário para o Supremo Tribunal Federal.

${ }^{185}$ Art. 584. O recurso será interposto perante o Presidente do Tribunal dentro de quinze (15) dias, contados da data da publicação do acórdão.

${ }^{186}$ Art. 585. Deferido o recurso em despacho que lhe apreciará as condições de admissibilidade, será aberta vista ao recorrido para responder no prazo de quinze (15) dias.

${ }^{187}$ Forma de pagamento do preparo recursal diferente daquela aplicável ao recurso de apelação. A apelação, segundo o Anteprojeto, deveria ser preparada no prazo de 10 (dez) dias, contado da data da interposição do recurso (artigo 568).

${ }^{188}$ Art. 586. Em seguida o recorrente pagará o preparo, inclusive as custas devidas ao Supremo Tribunal Federal e as despesas de remessa e retorno dos autos, sendo remetido o processo à secretaria do Supremo Tribunal Federal dentro em quinze (15) dias.

189 Art. 587. Denegado o recurso, o recorrente poderá interpor, dentro em quinze (15) dias, agravo de instrumento para o Supremo Tribunal Federal, observando-se, no que for aplicável, as disposições constantes do capítulo IV, título X, deste livro.

${ }^{190}$ Esses artigos disciplinavam apenas o procedimento interno de registro e autuação do recurso, determinavam que sempre seria dada vista ao Procurador Geral da República para se manifestar e que os recursos tinham revisor.
} 
republicana. Da mesma forma, o Regimento Interno de 1909, que tratava dessa espécie recursal em seus artigos 147 a $152^{191}$, agora sob a rubrica "Da Appellação Cível”.

O Regimento Interno de 1940, já elaborado durante a vigência da Constituição Federal de 1937, que denominava a espécie recursal de recurso ordinário, também se utilizava dessa expressão quando definia a competência do tribunal (artigo 22, II, $c$ e $e$ ), mas quando tratava do procedimento do recurso ordinário constitucional, continuou o fazendo sob a rubrica "Da Apelação" (artigos 176 a $188^{192}$ ).

O Regimento Interno de 1970, editado durante a vigência da Emenda Constitucional $n^{\circ}$ 01/1969, dispunha sobre o recurso ordinário constitucional com a terminologia parcialmente correta. Os artigos 289 a 291 previam o processamento do recurso ordinário em habeas corpus, com essa denominação, mas os artigos 301 a $303^{193}$ ainda utilizam a rubrica "Da Apelação Cível" para disciplinar o recurso ordinário constitucional em causas internacionais. Nenhuma das 08 (oito) emendas ao Regimento Interno alteraram o procedimento dessa espécie recursal.

O Regimento Interno do Supremo Tribunal Federal atualmente em vigor, que data de 1980 - ainda na vigência da Emenda Constitucional nº 01/1969, portanto - e ainda mantém a sua redação original em relação à disciplina do recurso ordinário constitucional, prevê a competência do Plenário (artigo $6^{\circ}$, III) e das Turmas (artigo 9º , II) para julgar certos casos "em recurso ordinário", porém denomina "recurso ordinário" aquele interposto contra decisão de única ou última instância proferida pela Justiça Militar (artigo 307). O recurso ordinário

\footnotetext{
${ }^{191}$ A disciplina dada pelo Regimento Interno do Supremo Tribunal Federal era mais detalhada. Dispunha-se que o recurso poderia ser interposto por ambas as partes ou por terceiro prejudicado (artigos 147 e 148); que o recurso não deveria ser conhecido em razão de preclusão lógica (artigo 148); que o recurso interposto por um litisconsorte aproveita aos demais, salvo se a matéria recorrida dissesse respeito apenas ao recorrente (artigo 149); que a desistência do recurso era faculdade do recorrente (artigo 150); que o prazo para recorrer era de 10 dias (artigo 151); e que a manifestação do Procurador Geral da República não era mais necessária, bem como o procedimento era o mesmo da apelação criminal - trâmites cartorários, remessa do recurso à revisão, julgamento por maioria de votos e permissão dos advogados das partes sustentarem oralmente na sessão de julgamento (artigos 152 e 136).

${ }_{192}$ Definiu-se: o efeito devolutivo amplo do recurso, em moldes muito próximos à atual disciplina legal (artigo 176); que a desistência do recurso era facultativo ao recorrente (artigo 177); que as razões deveriam ser apresentadas ao juízo a quo e que o recurso subiria ao tribunal nos mesmos autos (artigo 178); que o prazo para recolhimento do preparo recursal era de 10 dias, contados da data em que o recurso fosse registrado na secretaria do tribunal (artigo 179); que o relator seria sorteado (artigo 180); a forma de distribuição (artigo 181); que o recurso deveria ser remetido à revisão, após a apreciação pelo relator (artigo 182); os trâmites cartorários para a inclusão do recurso em pauta (artigo 183); ser possível a sustentação oral e que o julgamento seria tomado por maioria de votos (artigo 184); que o agravo retido (então agravo no auto do processo) seria julgado preliminarmente e que, se influísse no julgamento da apelação, o julgamento seria convertido em diligência (artigo 185); ser possível que um magistrado pedisse vista dos autos (artigo 186); a forma de apresentação e publicação do acórdão (artigo 187); e o efeito substitutivo do julgamento da apelação (artigo 187).

${ }^{193} \mathrm{O}$ tratamento legislativo voltou a ser bastante reduzido. Repetia-se as hipóteses de cabimento expostas na Carta Magna (artigo 301) e se previa apenas que haveria manifestação do Procurador Geral da República (artigo 302 ) e que o agravo retido seria julgado preliminarmente (artigo 303).
} 
constitucional era tratado sob as rubricas "Do Recurso de Habeas Corpus" (artigos 310 a $312^{194}$ ), "Do Agravo de Instrumento" (artigos 313 a 316 ${ }^{195}$ ) e "Da Apelação Cível” (artigo 318 a $320^{196}$ ).

Já o Regimento Interno do Superior Tribunal de Justiça, publicado em 1989, sob a vigência da atual Carta Magna, prevê ser da competência das Turmas daquele tribunal julgar recurso ordinário constitucional, mas utiliza esse nome apenas em relação às ações constitucionais (mandado de segurança e habeas corpus), enquanto ainda denomina de apelação e agravo o recurso ordinário constitucional interposto em causas internacionais ${ }^{197}$. Faz o mesmo quando determina o procedimento dos recursos (artigos 244 a $254^{198}$ ).

A falta de atualidade dos Regimentos Internos dos tribunais que têm competência para julgar o recurso ordinário constitucional é fator de insegurança e confusão, pois não permite que o operador do direito saiba, sem antes realizar um estudo mais profundo, qual o recurso que deve interpor contra determinada decisão judicial. É necessário que ambos os Regimentos Internos sejam revistos nesses pontos, para sanar esse vício.

A Lei ${ }^{\circ} 8.038 / 1990$, seguindo a má técnica legislativa a respeito do recurso ordinário constitucional, passou a usar a denominação "recurso ordinário" apenas em relação aos

\footnotetext{
${ }^{194}$ Previam o prazo de cinco dias para a interposição do recurso, a manifestação do Procurador Geral da República e a ausência de revisão.

${ }^{195}$ Recurso esse cabível não só contra decisões interlocutórias proferidas em causas internacionais (artigo 313, I), mas também contra a decisão do juízo a quo que não admitiu o processamento de recurso de competência do Supremo Tribunal Federal (artigo 313, II) e ou quando houvesse atraso injustificado superior a 30 dias do referido exame de admissibilidade (artigo 313, III).

196 Apenas previam sua hipótese de cabimento em causas internacionais (artigo 318), a manifestação do Procurador Geral da República e a dispensa de revisão (artigo 319) e o julgamento preliminar do agravo retido (artigo 320).

${ }^{197}$ Art. 13. Compete às Turmas:

(...) II - julgar em recurso ordinário:

a) os habeas corpus decididos em única ou última instância pelos Tribunais Regionais Federais ou pelos Tribunais dos Estados, do Distrito Federal e Territórios, quando denegatória a decisão;

b) os mandados de segurança decididos em única instância pelos Tribunais Regionais Federais ou pelos Tribunais dos Estados, do Distrito Federal e Territórios, quando denegatória a decisão.

III - julgar as apelações e os agravos nas causas em que forem partes Estado estrangeiro ou organismo internacional, de um lado, e, do outro, Município ou pessoa residente ou domiciliada no País;

${ }_{198}$ Os artigos 244 e 246 tratam do recurso ordinário constitucional em habeas corpus (apenas apontam que a lei é quem estabelece o procedimento, que deve ser dada vista ao Ministério Público pelo prazo de 10 dias para se manifestar, que não há revisão e que a disciplina subsidiária é o dos habeas corpus de competência originária do Superior Tribunal de Justiça), os artigos 247 e 248 do recurso ordinário constitucional em mandado de segurança (o procedimento é previsto no Código de Processo Civil, é dada vista ao Ministério Público para apresentar parecer em até cinco dias e não há revisão), os artigos 249 a 252 tratam do recurso ordinário constitucional interposto contra a sentença que julga a causa internacional (mais uma vez aponta que o Código de Processo Civil é quem determina o procedimento perante o juízo a quo e os requisitos de admissibilidade, estabelece a necessidade de manifestação do parquet em até 20 dias, afasta a necessidade de revisão, dispõe que a "apelação" será incluída em pauta antes do "agravo de instrumento" interposto no mesmo processo e que o agravo retido é julgado antes do recurso contra a sentença) e os artigos 253 e 254 do recurso interposto contra decisões interlocutórias proferida em causas internacionais (disciplina essa idêntica à do Código de Processo Civil e que também vale para os recursos interpostos contra decisão que nega seguimento a recurso especial).
} 
recursos interpostos em habeas corpus (artigos 30 a $32^{199}$ ) ou em mandado de segurança (artigos 33 a $35^{200}$ ). Em especial no que se refere a este último, deixou de tratar dos casos em que o Supremo Tribunal Federal seria competente para o julgamento do recurso, mencionando apenas as hipóteses em que o Superior Tribunal de Justiça teria competência.

Nas causas internacionais, a Lei $\mathrm{n}^{\circ}$ 8.038/1990 utilizava as denominações "apelação cível" e "agravo de instrumento" (artigos 36 e $37^{201}$ ), o que gerava ainda maior confusão.

O crime político, o habeas data e o mandado de injunção eram totalmente negligenciados, mesmo com a expressa disposição constitucional do cabimento do recurso ordinário nessas hipóteses.

Como se verifica pela descrição acima, mencionado diploma legal disciplinava mal extremamente mal - os recursos de competência dos tribunais superiores ${ }^{202}$, razão pela qual adveio a Lei ${ }^{\circ} 8.950 / 1994$, que voltou a incluir no corpo do Código de Processo Civil os recursos cabíveis ao Supremo Tribunal Federal e ao Superior Tribunal de Justiça, entre eles o recurso ordinário constitucional ${ }^{203}$.

Esta lei reintroduziu os revogados artigos 539 a 546 ao Código de Processo Civil ${ }^{204}$ $\left(\operatorname{artigos} 1^{\circ}\right.$ e $2^{\circ}$ ), e alterou a redação os artigos 539 e 540, que passaram a ter os seguintes textos:

\footnotetext{
${ }^{199}$ Art. 30. O recurso ordinário para o Superior Tribunal de Justiça, das decisões denegatórias de Habeas Corpus, proferidas pelos Tribunais Regionais Federais ou pelos Tribunais dos Estados e do Distrito Federal, será interposto no prazo de cinco dias, com as razões do pedido de reforma.

Art. 31. Distribuído o recurso, a Secretaria, imediatamente, fará os autos com vista ao Ministério Público, pelo prazo de dois dias.

Parágrafo único. Conclusos os autos ao relator, este submeterá o feito a julgamento independentemente de pauta. Art. 32. Será aplicado, no que couber, ao processo e julgamento do recurso, o disposto com relação ao pedido originário de Habeas Corpus.

${ }^{200}$ Art. 33. O recurso ordinário para o Superior Tribunal de Justiça, das decisões denegatórias de mandado de segurança, proferidas em única instância pelos Tribunais Regionais Federais ou pelos Tribunais de Estados e do Distrito Federal, será interposto no prazo de quinze dias, com as razões do pedido de reforma.

Art. 34. Serão aplicadas, quanto aos requisitos de admissibilidade e ao procedimento no Tribunal recorrido, as regras do Código de Processo Civil relativas à apelação.

Art. 35. Distribuído o recurso, a Secretaria, imediatamente, fará os autos com vista ao Ministério Público, pelo prazo de cinco dias.

Parágrafo único. Conclusos os autos ao relator, este pedirá dia para julgamento.

${ }^{201}$ Art. 36. Nas causas em que forem partes, de um lado, Estado estrangeiro ou organismo internacional e, de outro, município ou pessoa domiciliada ou residente no País, caberá:

I - apelação da sentença;

II - agravo de instrumento, das decisões interlocutórias.

Art. 37. Os recursos mencionados no artigo anterior serão interpostos para o Superior Tribunal de Justiça, aplicando-se-lhes, quanto aos requisitos de admissibilidade e ao procedimento, o disposto no Código de Processo Civil.

${ }^{202}$ ASSIS, 2011, pp. 651/652.

203 Idem, p. 652.

${ }^{204}$ MIRANDA e PIZZOL, 2009, p. 184.
} 
Art. 539. Serão julgados em recurso ordinário:

I - pelo Supremo Tribunal Federal, os mandados de segurança, os habeas data e os mandados de injunção decididos em única instância pelos Tribunais Superiores, quando denegatória a decisão;

II - pelo Superior Tribunal de Justiça:

a) os mandados de segurança decididos em única instância pelos Tribunais Regionais Federais ou pelos Tribunais dos Estados e do Distrito Federal e Territórios, quando denegatória a decisão;

b) as causas em que forem partes, de um lado, Estado estrangeiro ou organismo internacional e, do outro, Município ou pessoa residente ou domiciliada no País:

Parágrafo único. Nas causas referidas no inciso II, alínea b, caberá agravo das decisões interlocutórias.

Art. 540. Aos recursos mencionados no artigo anterior aplica-se, quanto aos requisitos de admissibilidade e ao procedimento no juízo de origem, o disposto nos Capítulos II e III deste título, observando-se, no Supremo Tribunal Federal e no Superior Tribunal de Justiça, o disposto nos seus regimentos internos.

Ou seja, foi eliminada a confusão que a Lei $n^{0}$ 8.038/1990 fazia em relação aos recursos nas causas internacionais e foram supridas as omissões referentes ao recurso em mandado de segurança de competência do Supremo Tribunal Federal e aos recursos em habeas data e mandado de injunção. Não se tratou do recurso em crime político porque esta matéria não compete ao Processo Civil ${ }^{205}$.

Também não há menção ao habeas corpus nos referidos dispositivos legais porque, ainda que este seja procedimento aplicável em caso de prisões civis, é instituto jurídico adstrito ao âmbito do Direito Processual Penal, tanto que previsto nos artigos 647 a 667 do Código de Processo Penal ${ }^{206}$.

Como, por óbvio, o Direito Processual Civil não se confunde nem se limita aos casos de incidência do Direito Civil, não se mostrou útil ou necessária a disciplina do recurso ordinário constitucional contra decisão proferida em sede de habeas corpus pelo Código de Processo Civil.

Finalizado o breve estudo histórico do recurso ordinário constitucional, passa-se ao exame das suas hipóteses de cabimento, propondo-se classificação diversa da prevista pelas normas constitucionais e infraconstitucionais.

\footnotetext{
${ }^{205}$ ROENICK, 1999, p. 155.

${ }^{206}$ Idem, p. 156.
} 


\section{RECURSO ORDINÁRIO CONSTITUCIONAL - HIPÓTESES DE CABIMENTO}

Tanto a Constituição Federal de 1988, em seus artigos 102, II, e 105, II, quanto o Código de Processo Civil, no seu artigo 539, adotam como critério de classificação das hipóteses de cabimento do recurso ordinário constitucional o tribunal competente para o seu julgamento - Supremo Tribunal Federal ou Superior Tribunal de Justiça - o que é de pouca relevância teórica ${ }^{207}$.

Pode-se entender a razão dessa adoção por parte da Carta Magna. Ela disciplina as competências dos tribunais superiores, apenas incluindo o recurso ordinário constitucional entre essas. Assim, a maior preocupação da norma constitucional é com o tribunal, pois delimita o âmbito de atuação deste, não com o recurso.

Todavia, o mesmo não pode ser dito em relação à legislação infraconstitucional. Esta visa a prever o processamento do recurso - seu objeto principal - devendo, dessa forma, enumerar suas hipóteses de cabimento com base em critério de relevância teórica e prática maior que o tribunal competente para o seu julgamento.

A doutrina tentou fugir da categoria legal, dando maior relevo às decisões recorríveis $^{208}$, mas nem sempre obteve grande sucesso.

Foi José CARlos BARbosa Moreira quem chegou mais próximo de uma classificação ideal, embora não tenha explicitado o critério adotado por ele para tanto:

310. Panorama geral - Emprega a Carta da República a denominação genérica de 'recurso ordinário', sem preocupação de ordem científica, com relação a uma série de remédios heterogêneos, da competência ora do Supremo Tribunal Federal (art. 102, $\mathrm{n}^{\mathrm{o}}$ II), ora do Superior Tribunal de Justiça (art. 105, $\mathrm{n}^{\mathrm{o}}$ II). Dentre eles,

\footnotetext{
${ }^{207}$ ASSIS, 2008, p. 77.

208 "Especificamente, ordinário é o recurso interponível para o Supremo Tribunal Federal ou para o Superior Tribunal de Justiça, por três diferentes formas. Nessa medida, a espécie constitucional do recurso transmuta-se em gênero, ou subgênero; daí as três subespécies: (a) recurso ordinário para o STF, na improcedência de algumas ações julgadas em instância única em tribunais superiores (Constituição, art. 102, inc. II, alínea $a$ ); (b) recurso ordinário para o STJ de certos acórdãos de tribunais regionais federais e tribunais estaduais aí julgados originalmente, se improcedente a ação (Constituição, art. 105, inc. II, alínea $b$ ), ou também em última instância, se denegado o habeas corpus (idem, idem, alínea a); (c) recurso com idêntica denominação para o STJ de decisões interlocutórias e sentenças prolatadas por juiz federal nas causas em que forem partes, de um lado, Município ou pessoa residente ou domiciliada no país, e, de outro, Estado estrangeiro ou organismo internacional (Constituição, art. 105, inc. II, alínea $c$ ). Neste último caso, procedente ou improcedente a ação." (AMORIM, 2005, p. 94).

O autor tenta fugir da classificação legal, atribuindo maior importância à causa em que a decisão recorrida foi proferida, mas não escapa de tomar como primeiro critério para sua classificação o tribunal que tem a competência para o julgamento do recurso ordinário constitucional.
} 
interessam ao processo civil os previstos no art. 102, $\mathrm{n}^{\circ}$ II, a (salvo no que concerne ao habeas corpus) e no art. $105, \mathrm{n}^{\circ} \mathrm{II}, \mathrm{b}$ e c. Esta última letra diz respeito às 'causas em que forem partes Estado estrangeiro ou organismo internacional, de um lado, e, do outro, Município ou pessoa residente ou domiciliada no País' (texto agora substancialmente reproduzido no art. 539, $\mathrm{n}^{\circ}$ II, b, do Código). Segundo se verá melhor adiante (infra, comentários $\mathrm{n}^{\circ} 312$ ao art. 539), o recurso mencionado em ambos esses dispositivos é equiparável, conforme o caso, à apelação ou ao agravo.

Restam os recursos ordinários a que aludem os arts. 102, $\mathrm{n}^{\mathrm{o}} \mathrm{II}$, a (no que tange ao mandado de segurança, ao habeas data e ao mandado de injunção), e 105, $\mathrm{n}^{\circ}$ II, b, da Constituição. Têm eles em comum a característica de apenas caberem contra acórdão proferido por tribunal (não contra decisão monocrática de relator!) 'em última instância’, isto é, em processo de sua competência originária. Na hipótese do art. 102, n⿳ II, a, o acórdão pode emanar de qualquer dos 'Tribunais Superiores'; na do art. 105, $\mathrm{n}^{\mathrm{o}}$ II, b, de Tribunal Regional Federal ou de tribunal local. Além disso, é necessário que a decisão impugnada seja denegatória de mandado de segurança ou (no caso do art. 102, ${ }^{\text {o }}$ II, a) de habeas data ou mandado de injunção. ${ }^{209}$

De início, verifica-se que o renomado professor trata somente dos casos em que o recurso ordinário constitucional tem relevância para o Processo Civil. Exclui, assim, os que podem ser interposto em habeas corpus e em ações que versem sobre crime político.

$\mathrm{O}$ autor não se vale do órgão competente para julgar o recurso como baliza para classificar as suas hipóteses de cabimento, mas sim a causa em que a decisão recorrida foi proferida, apesar de não apontar expressamente este ponto como o norteador da sistematização adotada.

Define duas categorias: (i) o recurso ordinário constitucional nas causas internacionais e (ii) o recurso ordinário constitucional nas ações constitucionais - mandado de segurança, mandado de injunção e habeas data.

O critério utilizado é o mais correto para classificar as modalidades de recurso ordinário constitucional, pois há grandes diferenças entre elas dependendo da ação em que a decisão atacada foi proferida, não do tribunal que tem a competência para o seu julgamento.

Sendo assim, divide-se o recurso ordinário constitucional em três subespécies, dependendo da natureza do processo em que sobreveio a decisão objeto de recurso:

(i) interposto em ações constitucionais - habeas corpus, habeas data, mandado de segurança e mandado de injunção -, previsto nos artigos 102, II, $a$, e 105, II, $a$ e $b$, da Constituição Federal e artigo 539, I e II, a, do Código de Processo Civil;

${ }^{209}$ BARBOSA MOREIRA, 2010, pp. 574/575. 
(ii) interposto em causas internacionais - aquelas em que é parte Estado estrangeiro ou organismo internacional, de um lado, e Município ou pessoa residente ou domiciliada no Brasil, de outro -, previsto no artigo 105, II, c, da Constituição Federal e artigo 539, II, $b$, do Código de Processo Civil; e

(iii) interposto em ações que versam sobre crime político, previsto no artigo 102, II, $b$, da Constituição Federal.

Isso posto, passa-se a expor, de forma sucinta e com destaques àquelas que interessam ao Processo Civil, as características de cada uma das subespécies de recurso ordinário constitucional, de acordo com a classificação exposta acima.

Por enquanto cabe apenas descrever as hipóteses de cabimento do recurso ordinário constitucional. Análise crítica dessas, que também levará em conta as origens históricas do recurso, as funções dos tribunais superiores nacionais e um breve apontamento de quais são as funções e os processos julgados por tribunais superiores estrangeiros, será feita no Capítulo 7 desta dissertação.

\subsection{Ações constitucionais}

Antes de se tratar especificamente das hipóteses de interposição de recurso ordinário constitucional em cada uma das ações constitucionais, deve-se delinear os seus traços comuns, razão pela qual está sendo utilizada essa classificação neste trabalho.

A decisão, proferida em ação constitucional - habeas corpus, habeas data, mandado de segurança ou mandado de injunção -, contra a qual pode ser interposto recurso ordinário constitucional deve ser, (i) denegatória, (ii) colegiada, (iii) de instância final e (iv) proferida por tribunal.

O conceito de decisão denegatória não enfrenta maiores controvérsias na doutrina ${ }^{210}$ ou na jurisprudência ${ }^{211}$. Denegatória é a decisão que, por qualquer razão, seja de mérito, seja processual, não confere o writ ao impetrante. A sua interpretação é a mais ampla possível ${ }^{212}$.

\footnotetext{
${ }^{210}$ AMERICANO, 1965, pp. 73/74; AMORIM, 2005, p. 196; ASSIS, 2008, p. 78/79; BARBI, 1991, p. 228; BARBOSA, 1990, p. 60; BARBOSA MOREIRA, 2010, p. 576; BERMUDES, 2010, p. 224; BUENO, 2011, p. 260; CARREIRA ALVIM, 2011, p. 179; DIDIER JR. e CUNHA, 2010, p. 246; LEYSER, 2000, p. 490; LIMA, G., 2007, p. 50; MARCATO, 2006, p. 53; MIRANDA e PIZZOL, 2009, p. 186; NEVES, 2011; ORIONE NETO, 2009, p. 429; SANTOS, 1996, p. 31; SOUZA, 2007, p. 76.

${ }^{211}$ Cita-se NEGRÃO et al (2012, p. 716) para resumir o posicionamento jurisprudencial:

"Art. 539: 5. 'A locução constitucional - 'quando denegatória a decisão' - tem sentido amplo, pois não só compreende as decisões dos tribunais que, apreciando o meritum causae, indeferem o pedido de mandado de segurança, como também abrange aquelas que, sem julgamento do mérito, operam a extinção do processo' (RTJ 132/718).
} 
A decisão também deve ser colegiada. Logo, percebe-se que, apesar da Constituição Federal usar o termo "decisão", o provimento jurisdicional, proferido em ação constitucional, recorrível por meio de recurso ordinário constitucional sempre será um acórdão ${ }^{213}$.

Há divergência, tanto na doutrina ${ }^{214}$, quanto na jurisprudência ${ }^{215}$, se é cabível recurso ordinário constitucional contra o acórdão que julga agravo regimental interposto contra a decisão monocrática do relator, que denega ação constitucional. Ou seja, se, por exemplo, impetrado mandado de segurança, o relator, monocraticamente, denega a ordem, o impetrante interpõe agravo regimental contra essa decisão e a turma julgadora mantém o entendimento denegatório, se seria cabível recurso ordinário constitucional contra este acórdão.

Considera-se ser cabível recurso ordinário constitucional nessa hipótese. Conforme já exposto anteriormente, essa espécie recursal serve de defesa ao cidadão contra eventual arbítrio do Estado, não podendo encontrar restrições ilegítimas. A Constituição Federal não veda o cabimento de recurso ordinário constitucional contra acórdão que julga agravo regimental - acórdão esse, aliás, que caracteriza decisão final -, tampouco o faz a legislação infraconstitucional. Assim, essa restrição se revela totalmente injustificada.

Assim, cabe recurso ordinário ao STF ou ao STJ (v. incisos I e II) contra decisão de Tribunal Superior, de TRF ou de Tribunal de Justiça que, em mandado de segurança julgado em única instância:

- julga extinto o processo, sem apreciação do mérito (STJ-1 ${ }^{\mathrm{a}}$ T., RMS 21.721, Min. Teori Zavascki, j. 6.2.07, DJU 22.2.07; STJ-RTJ 160/472; RSTJ 9/187, bem fundamentado, 14/157, 60/181, 69/151, 71/163, 92/378; STJBol. AASP 1.655/218, em. 13);

- pronuncia a decadência (STF-1 ${ }^{\mathrm{a}}$ T., RMS 21.363-9, Min. Sepúlveda Pertence, j. 8.9.92, DJU 25.9.92; STJ-3 ${ }^{\mathrm{a}}$ T., RMS 470, Min. Cláudio Santos, j. 28.8.90, DJU 5.11.90);

- não conhece do mandado, por entendê-lo incabível (RTJ 144/485; STJ-2a T., RMS, 11.537-MA, Min. Eliana Calmon, j. 6.2.01, maioria, DJU 29.10.01);

- concede parcialmente a segurança (STJ-5 ${ }^{\mathrm{a}}$ T., RMS 17.650, Min. Esteves Lima, j. 1.3.05, DJU 11.4.05; STJ-2 ${ }^{\mathrm{a}}$ T., RMS 3.826-2, Min. Peçanha Martins, j. 11.5.94, DJU 27.6.94), considerando-se, neste caso, erro grosseiro a interposição de recurso especial no lugar do recurso ordinário (STJ-3 ${ }^{\mathrm{a}}$ T., RMS 7.647, Min. Menezes Direito, j. 4.12.97, DJU 16.2.98).”.

${ }^{212}$ MENDONÇA, 2006, p. 603.

213 THEODORO JÚNIOR, 1993, p. 09.

${ }^{214}$ FREDIE DIDIER JÚNIOR e LEONARDO JOSÉ CARNEIRO DA CUNHA (2010, p. 246) advogam o não cabimento de recurso ordinário constitucional nesta hipótese, enquanto BERNARDO PIMENTEL SOUZA (2011, p. 607) e DANIEL AMORIM ASSUMPÇÃO NEVES (2011) defendem o cabimento do recurso ordinário constitucional também neste caso.

${ }^{215}$ Mais uma vez, para resumir a posição jurisprudencial, valemo-nos de NEGRÃo et al (2012, pp. 716/717):

“Art. 539: 5a. Indeferimento liminar e monocrático. Cabe agravo (LMS $10 \S 1^{\circ}$ ) e não recurso ordinário, contra a decisão monocrática que indefere, liminarmente, mandado de segurança em processo de competência originária de tribunal (RSTJ 11/191, 32/141, 34/176, 48/543, 83/379; STJ-RT 699/175, STJ-RJTJERGS 200/43, STJ-JTAERGS 91/389). 'A hipótese não comporta a aplicação do princípio da fungibilidade recursal' (STJ-4 ${ }^{\mathrm{a}} \mathrm{T}$., RMS 12.117, Min. Jorge Scartezzini, j. 26.10.04, DJU 6.12.04), por estar-se diante de erro grosseiro (RSTJ 147/79).

Então, não provido o agravo contra a decisão do relator que denega liminarmente a segurança, caberá recurso ordinário para o STJ (STJ-4 ${ }^{\mathrm{a}}$ T., RMS 11.654, Min. Aldir Passarinho Jr., j. 28.8.01, DJU 4.2.02; STJ-6 ${ }^{\mathrm{a}}$ T., RMS 5.921, Min. Fernando Gonçalves, j. 4.2.97, DJU 10.3.97; STJ-3 ${ }^{\mathrm{a}}$ T., RMS 13.574, Min. Menezes Direito, j. 28.5.02, DJU 26.8.02). Contra: 'Indeferimento de petição inicial de mandado de segurança por ausência de prova pré-constituída. Desprovimento de agravo regimental, que não enseja recurso ordinário' (STJ-6 ${ }^{\mathrm{a}}$ T., RMS 13.596, Min. Fontes de Alencar, j. 19.11.02, DJU 17.3.03).”. 
O recurso ordinário constitucional deve ser interposto contra decisão final, ou seja, devem ser esgotadas as vias recursais ordinárias anteriores para que caiba esta espécie de recurso constitucional ${ }^{216}$.

Esgotamento das vias recursais ordinárias não significa que devam, necessariamente, ser opostos embargos de declaração contra o acórdão denegatório da ação constitucional. Os embargos de declaração não são recurso ordinário em sentido amplo, conforme exposto no Capítulo 3 deste trabalho, mas sim recurso sui generis, pois não estão ligados à sucumbência, seu julgamento não substitui a decisão recorrida e podem ter por objeto apenas a fundamentação de sentença ou acórdão, não o dispositivo ${ }^{217}$.

Não faz sentido exigir a oposição de embargos de declaração para que seja caracterizada decisão de última instância e, consequentemente, cabível recurso ordinário constitucional, porque os embargos de declaração sempre podem ser opostos, o que faria com que nunca houvesse decisão de última instância, já que eles deveriam ser apresentados ao infinito $^{218}$.

As hipóteses de cabimento de embargos de declaração são limitadas - contradição, omissão, obscuridade e, eventualmente, erro material - sendo que há sanção para a oposição desnecessária $^{219}$ (artigo 538, parágrafo único, do Código de Processo Civil), bem como eles são recurso facultativo, nunca sendo necessária a sua oposição ${ }^{220}$.

Dessa forma, para que seja caracterizada decisão de última instância não é necessário que sejam opostos embargos de declaração, mas sim que sejam esgotadas as vias recursais ordinárias.

Por fim, deve-se anotar que há divergência em relação ao último requisito necessário para o cabimento de recurso ordinário constitucional em ações constitucionais, ou seja, quanto à necessidade de o acórdão recorrido ter sido prolatado por tribunal.

\footnotetext{
216 "Ao contrário do que pode parecer à primeira vista (em razão de o constituinte de 1988 ter utilizado o vocábulo genérico 'decisão' na alínea b do inciso II do artigo 105), não cabe recurso ordinário em mandado de segurança para o Superior Tribunal de Justiça contra decisão monocrática proferida por magistrado de corte regional ou local. O próprio preceito constitucional estabelece que tal modalidade de recurso serve para combater pronunciamentos de 'Tribunais'. Daí a incidência do artigo 163 do Código de Processo Civil, com o cabimento do recurso ordinário apenas contra acórdãos. Além do mais, contra decisão monocrática há recurso específico para órgão colegiado da própria corte de origem, o que impede o imediato acesso a tribunal ad quem, consoante o princípio do esgotamento das vias recursais." (SOUZA, 2007, p. 79).

Aqui cabe apenas a explicação que o entendimento aplicável ao mandado de segurança de competência do Superior Tribunal de Justiça, exposto na citação, também se aplica às demais ações constitucionais e aos recursos endereçados ao Supremo Tribunal Federal, sem qualquer ressalva.

${ }^{217}$ CARNEIRO, 2005, p. 482; e SICA, 2007, pp. 142/143.

${ }^{218}$ CARNEIRO, 2005, p. 482; e SICA, 2007, p. 144.

${ }^{219}$ SICA, 2007, pp. 143/144.

${ }^{220}$ Idem, p. 143.
} 
A jurisprudência do Supremo Tribunal Federal ${ }^{221}$ e do Superior Tribunal de Justiça ${ }^{222}$ entende que esse requisito existe, ou seja, que não é cabível recurso ordinário constitucional contra acórdão proferido por turma recursal de juizado especial cível que julgue mandado de segurança originariamente ${ }^{223}$.

Inquestionável a posição do Supremo Tribunal Federal, já que turma recursal não se confunde de forma alguma com tribunal superior, sendo que a sua competência recursal ordinária se limita a recursos interpostos contra decisões proferidas pelos tribunais superiores.

Porém, a doutrina diverge quanto ao cabimento de recurso ordinário constitucional dirigido ao Superior Tribunal de Justiça.

SIDNEI AMENDOEIRA JR. ${ }^{224}$ concorda com o entendimento jurisprudencial de que tribunal e turma recursal não se confundem, mas TIAGO FIGUEIREDO GONÇALVES entende que seria possível interpor recurso ordinário constitucional contra acórdão prolatado por turma recursal que denegasse mandado de segurança ${ }^{225}$. Considera que o termo "tribunal" deve ter sua interpretação revisada, já que a turma recursal seria equiparável ao antigo Tribunal de Alçada, formado apenas por juízes de primeiro grau, e porque julgamento colegiado, no Brasil, implicaria estrutura de tribunal. Em especial no que se refere ao recurso ordinário constitucional, o duplo grau de jurisdição seria violado caso ele não fosse cabível no âmbito dos juizados especiais cíveis.

O disposto na Súmula $n^{\circ} 376$ do Superior Tribunal de Justiça ${ }^{226}$, que atribui à turma recursal a competência para julgar mandado de segurança contra ato de juizado especial, reforça a posição favorável ao cabimento de recurso ordinário constitucional também contra decisão de turma recursal.

Mas também se deve levar em conta que o texto da Carta Magna e do Código de Processo Civil é expresso em atribuir competência ao Superior Tribunal de Justiça para julgar recurso ordinário constitucional contra acórdão denegatório de mandado de segurança

\footnotetext{
${ }^{221}$ STF, AgRg no RMS no 26.259/PR, Rel. Min. Celso de Mello, $2^{\text {a }}$ Turma, j. 16/10/2007; e STF, AgRg no RMS $\mathrm{n}^{\circ}$ 26.058/DF, Rel. Min. Sepúlveda Pertence, $1^{\mathrm{a}}$ Turma, j. 02/03/2007.

${ }^{222}$ STJ, RMS n ${ }^{\circ} 35.079 / \mathrm{MT}$, Rel. Min. Herman Benjamin, $2^{\mathrm{a}}$ Turma, j. 11/12/2012; STJ, EDcl no Ag n ${ }^{\circ}$ 959.393/RJ, Rel. Min. Maria Isabel Gallotti, $4^{\mathrm{a}}$ Turma, j. 17/11/2011; e STJ, AgRg no RMS no 24.426/RJ, Rel. Min. Luis Felipe Salomão, 4a Turma, j. 13/10/2009.

${ }^{223}$ Trata-se apenas do recurso ordinário constitucional que julga mandado de segurança porque a competência para o primeiro julgamento de causas internacionais é exclusiva do juiz federal (artigo 109, II, da Constituição Federal e artigo $3^{\circ}, \S 2^{\circ}$, I, da Lei $\mathrm{n}^{\circ} 10.259 / 01$ ) e porque o debate em relação ao acórdão proferido por turma recursal que julgue habeas corpus, em competência originária ou recursal, foge do âmbito desta dissertação, que pretende discutir a fundo apenas questões envolvendo o recurso ordinário constitucional em processo civil.

${ }^{224}$ AMENDOEIRA JR., 2012, p. 208.

${ }^{225}$ GONÇALVES, T., 2006.

${ }^{226}$ Súmula no 376: "Compete a turma recursal processar e julgar o mandado de segurança contra ato de juizado especial".
} 
proferido por "Tribunais Regionais Federais ou pelos tribunais dos Estados, do Distrito Federal e Territórios", não simplesmente proferido por tribunal.

Em que pese a elogiável e bem fundamentada posição de TIAGO FiguEIREDO GONÇALVES, concorda-se com o entendimento majoritário, no sentido de que o recurso ordinário constitucional não é cabível contra acórdão proferido por turma recursal, em exercício de competência originária, que denega mandado de segurança.

O texto da Carta Magna, reproduzido pelo Código de Processo Civil, não abre margem para interpretação: o recurso ordinário constitucional só pode ser interposto contra decisão de Tribunal Regional Federal ou de Tribunal de Justiça Estadual ou Distrital. Os juizados especiais são sistema autônomo, que não fazem parte da estrutura dos tribunais ${ }^{227}$. Essa autonomia, ainda que venha sendo mitigada em casos excepcionais ${ }^{228}$, faz com que o

${ }^{227}$ THEODORO JÚNIOR, 2009b, pp. 413/414.

No mesmo sentido, o acórdão que julgou o REsp nº 21.664/MS, da relatoria do Min. ATHOS GUSMÃo CARNEIRO, o primeiro a enfrentar a fundo a questão sobre a natureza jurídica dos juizados especiais cíveis como tribunais, e que foi um dos precedentes que deu origem à edição da Súmula no 203 do Superior Tribunal de Justiça: "Não cabe recurso especial contra decisão proferida por órgão de segundo grau dos Juizados Especiais".

${ }^{228}$ A jurisprudência recente do Superior Tribunal de Justiça confere competência excepcional aos tribunais para julgar mandado de segurança interposto contra decisão proferida no âmbito dos juizados especiais que trata da competência destes para julgar a demanda. Assim, cabe aos tribunais verificar, de forma excepcional, se os juizados especiais avocam para si mais competência do que teriam pelo disposto na lei:

"Processo civil. Recurso em Mandado de Segurança. Mandamus impetrado, perante Tribunal de Justiça, visando promover controle de competência de decisão proferida por Juizado Especial Cível. Possibilidade. Ausência de confronto com a jurisprudência consolidada do STJ, que veda apenas a impetração de mandado de segurança para o controle do mérito das decisões proferidas pelos Juizados Especiais.

- Não se admite, consoante remansosa jurisprudência do STJ, o controle, pela justiça comum, sobre o mérito das decisões proferidas pelos juizados especiais. Exceção é feita apenas em relação ao controle de constitucionalidade dessas decisões, passível de ser promovido mediante a interposição de recurso extraordinário.

- A autonomia dos juizados especiais, todavia, não pode prevalecer para a decisão acerca de sua própria competência para conhecer das causas que lhe são submetidas. É necessário estabelecer um mecanismo de controle da competência dos Juizados, sob pena de lhes conferir um poder desproporcional: o de decidir, em caráter definitivo, inclusive as causas para as quais são absolutamente incompetentes, nos termos da lei civil.

- Não está previsto, de maneira expressa, na Lei no 9.099/95, um mecanismo de controle da competência das decisões proferidas pelos Juizados Especiais. É, portanto, necessário estabelecer esse mecanismo por construção jurisprudencial.

- Embora haja outras formas de promover referido controle, a forma mais adequada é a do mandado de segurança, por dois motivos: em primeiro lugar, porque haveria dificuldade de utilização, em alguns casos, da Reclamação ou da Querela Nullitatis; em segundo lugar, porque o mandado de segurança tem historicamente sido utilizado nas hipóteses em que não existe, no ordenamento jurídico, outra forma de reparar lesão ou prevenir ameaça de lesão a direito.

- O entendimento de que é cabível a impetração de mandado de segurança nas hipóteses de controle sobre a competência dos juizados especiais não altera o entendimento anterior deste Tribunal, que veda a utilização do writ para o controle do mérito das decisões desses juizados.

Recurso conhecido e provido." (STJ, RMS n ${ }^{\circ}$ 17.524/BA, Rel. Min. Nancy Andrighi, Corte Especial, j. 02/08/2006, grifos nossos)

No mesmo sentido, entre outros: STJ, RMS no 33.947/RJ, Rel. Min. Herman Benjamin, $2^{\mathrm{a}}$ Turma, j. 06/12/2012; STJ, AgRg no RMS no 32.024/BA, Rel. Min. Adilson Vieira Macabu, 5a Turma, j. 15/05/2012; e STJ, EDcl no AgRg no AgRg no RMS n ${ }^{\circ}$ 32.632/ES, Rel. Min. Ricardo Villas Bôas Cueva, $3^{\mathrm{a}}$ Turma, j. 06/03/2012. 
recurso ordinário constitucional esteja fora do alcance daqueles que litigam perante os juizados especiais.

Expostas as diretrizes gerais de cabimento do recurso ordinário constitucional, parte-se para a análise pontual do recurso em cada uma das ações constitucionais - habeas corpus, mandado de segurança, e habeas data e mandado de injunção, estes últimos analisados em conjunto.

\subsubsection{Habeas corpus}

Conforme já mencionado anteriormente, o habeas corpus é remédio processualconstitucional referente ao Direito Processual Penal, sendo usado pelo Direito Civil apenas em casos de prisão por dívida de alimentos e de depositário infiel - esta último já considerada ilícita pelo Supremo Tribunal Federal, com a edição da Súmula Vinculante n ${ }^{\circ}$ 25: "É ilícita a previsão de depositário infiel, qualquer que seja a modalidade do depósito". Como, por óbvio, o Direito Processual Civil não se confunde nem se limita aos casos de incidência do Direito Civil, não será examinado com grande afinco o recurso ordinário constitucional contra decisão proferida em sede de habeas corpus.

Essa modalidade de recurso ordinário constitucional é de competência do Supremo Tribunal Federal (artigo 102, II, $a$, da Constituição Federal), em certos casos, e do Superior Tribunal de Justiça (artigo 105, II, $a$, da Constituição Federal) em outros.

O Supremo Tribunal Federal é competente para julgar os recursos interpostos contra decisão proferida por tribunal superior ${ }^{229}$ - Superior Tribunal de Justiça, Tribunal Superior Eleitoral, Tribunal Superior do Trabalho ou Superior Tribunal Militar -, em única instância ${ }^{230}$. Deve a decisão ser denegatória e colegiada, conforme já tratado acima.

Já o Superior Tribunal de Justiça tem competência para o julgamento dos recursos ordinários constitucionais cabíveis contra decisão colegiada de única ou última instância, proferida por Tribunal Regional Federal ou Tribunal de Justiça dos Estados ou do Distrito Federal e Territórios ${ }^{231}$, válido também o requisito de ser o provimento denegatório.

Ou seja, a competência do Superior Tribunal de Justiça não se limita aos habeas corpus de competência originária de tribunais, mas abarca também os casos em que estes

\footnotetext{
${ }^{229}$ Evidente que, entre os "tribunais superiores" não está o próprio Supremo Tribunal Federal, pois não seria lógico que este julgasse, em sede de recurso ordinário, decisão colegiada proferida por ele próprio. Nesse sentido: SIQUEIRA, 2001, p. 43.

${ }^{230}$ ASSIS, 2008, p. 89.

231 Vide nota 227.
} 
julgam recurso em habeas corpus $^{232}$. Isso denota a maior preocupação da Constituição Federal de 1988 em permitir que o impetrante, nos casos de habeas corpus, possa rediscutir todas as questões em instância superior ${ }^{233}$.

Essa preocupação se justifica por razões históricas, tendo em vista que todas as Constituições Republicanas brasileiras previam a interposição de recurso ordinário em habeas corpus, nos termos do item 4.2 desta dissertação. A Carta Magna vigente seguiu essa linha e fez com que o cabimento do recurso ordinário constitucional em matéria de habeas corpus fosse mais amplo do que nas demais ações constitucionais, como se verá em seguida.

\section{$\underline{\text { 5.1.2 Mandado de segurança }}$}

O mandado de segurança é a ação constitucional de maior importância para o estudo do recurso ordinário constitucional em Direito Processual Civil, uma vez que, em comparação com o mandado de injunção e o habeas data, é o que é impetrado em maior número pelos jurisdicionados.

Não é o objetivo deste trabalho um exame do instituto jurídico do mandado de segurança, mas sim das hipóteses de cabimento do recurso ordinário constitucional nesse tipo de ação constitucional. Por isso serão deixadas de lado a conceituação do writ, as suas características e hipóteses de impetração.

Assim como o habeas corpus, o recurso ordinário constitucional em mandado de segurança é de competência do Supremo Tribunal Federal (artigo 102, II, a, da Constituição Federal e artigo 539, I, do Código de Processo Civil) ou do Superior Tribunal de Justiça (artigo 105, II, $b$, e artigo 539, II, $a$, dos referidos diplomas legais, respectivamente), dependendo do órgão prolator da decisão recorrida.

O Supremo Tribunal Federal só tem competência para julgar os recursos interpostos contra acórdão denegatório de mandado de segurança, proferido por tribunal superior, em única instância ${ }^{234}$. A lógica é a mesma do habeas corpus, exposta no item anterior.

Por outro lado, em relação ao Superior Tribunal de Justiça, a sistemática do recurso ordinário constitucional em mandado de segurança não é a mesma utilizada no habeas corpus.

\footnotetext{
${ }^{232}$ SOUZA, 2007, p. 85.

233 "A superlativa relevância do direito fundamental tutelado através do writ, como evidencia a cláusula 'última instância', transforma o STJ em verdadeiro terceiro grau de jurisdição em alguns casos, na jurisdição penal. No âmbito civil, porém, o decreto de prisão se origina de ato do juiz de direito, de modo que os tribunais locais e regionais conhecerão do habeas corpus de modo originário (v.g., art. 95, XII, a, da CERS/89) e o STJ atuará, então, como instância de revisão." (ASSIS, 2008, p. 90).

${ }^{234}$ SOUZA, 2007, p. 83.
} 
São recorríveis apenas os acórdãos denegatórios da segurança, proferidos por tribunal ordinário, em única instância. Não é cabível essa espécie recursal contra decisão que julga recurso em mandado de segurança, como no habeas corpus, mas somente contra a que julgue o writ originariamente ${ }^{235}$.

Isso demonstra a maior preocupação da Carta Magna em proteger a liberdade de locomoção, tutelada pelo habeas corpus (artigo $5^{\circ}$, LXVIII), do que os demais direitos tutelados por mandado de injunção - suprimir lacuna legislativa que impeça o exercício de direitos ou liberdades constitucionais, bem como prerrogativas inerentes à nacionalidade, à soberania ou à cidadania (artigo $\left.5^{\circ}, \mathrm{LXXI}\right)$-, por habeas data - obter ou retificar informações constantes em registros públicos (artigo $5^{\circ}$, LXXII) -, ou por mandado de segurança - direito líquido e certo violado pelo Estado, que não posse ser tutelado por habeas corpus ou habeas data (artigo $5^{\circ}$, LXIX).

Há justificativa histórica para a adoção desse posicionamento, pois apenas a Constituição Federal de 1967, de curta vigência, permitia a interposição de recurso ordinário constitucional contra decisão denegatória de mandado de segurança proferida em grau recursal. A Carta de 1946, a de maior correspondência com a atual, também admitia essa espécie recursal somente nos mandados de segurança de competência originária dos tribunais ordinários.

\section{$\underline{\text { 5.1.3 Habeas data e mandado de injunção }}$}

O cabimento do recurso ordinário constitucional nas ações constitucionais de habeas data e de mandado de injunção será estudado conjuntamente porque não há diferença entre as particularidades dessas, poupando-se explicações supérfluas.

A Carta de 1988 foi a primeira a prever a existência de recurso ordinário constitucional em habeas data e em mandado de injunção, atribuindo apenas ao Supremo Tribunal Federal ${ }^{236}$ a competência para julgar esse recurso nessas ações constitucionais (artigo 102, II, a). Norma idêntica está no artigo 539, I, do Código de Processo Civil.

Dessa forma, cabe recurso ordinário constitucional ao Supremo Tribunal Federal interposto contra acórdão denegatório de mandado de injunção ou habeas data, proferido em única instância, por tribunal superior. Não há correspondente recurso de competência do

\footnotetext{
${ }^{235}$ ASSIS, 2011, p. 663.

${ }^{236}$ SOUZA, 2007, p. 84.
} 
Superior Tribunal de Justiça, como ocorre com o habeas corpus e com o mandado de segurança.

O artigo 20, II, $b$, da Lei $\mathrm{n}^{\circ} 9.507 / 1997^{237}$, que trata do procedimento do habeas data, criou certa dúvida ao prever o cabimento de recurso ordinário ao Superior Tribunal de Justiça, contra decisão denegatória proferida em única instância por Tribunal Regional Federal.

Entretanto, esse dispositivo legal é inconstitucional, pois atribui competência ao Superior Tribunal de Justiça fora dos limites estabelecidos no artigo 105 da Carta Magna ${ }^{238}$. A única interpretação possível desse artigo de lei é que ele reitera o cabimento de recurso especial, nas hipóteses específicas a esta espécie recursal ${ }^{239}$.

\section{$\underline{5.2 \quad \text { Causas internacionais }}$}

A segunda subespécie de recurso ordinário constitucional é a em causas internacionais, denominação comumente utilizada pela doutrina para designar as ações em que é parte, de um lado, Estado estrangeiro ou organismo internacional e, de outro, Município ou pessoa residente ou domiciliada no Brasil ${ }^{240}$.

As causas internacionais são processadas e julgadas por juízes federais de primeiro grau, nos termos do artigo 109, II, da Carta da República. Como só é cabível o recurso ordinário constitucional nesse tipo de ação, que é de competência exclusiva do Superior Tribunal de Justiça (artigo 105, II, c, da Constituição Federal e artigo 539, II, b, do Código de

\footnotetext{
237 “Art. 20. O julgamento do habeas data compete:

(...) II - em grau de recurso:

(...) b) ao Superior Tribunal de Justiça, quando a decisão for proferida em única instância pelos Tribunais Regionais Federais;"

238 "O dispositivo é inconstitucional porque a competência daquele Tribunal é taxativamente estabelecida pela Constituição Federal, vedado o seu alargamento por lei federal. Assim, nos casos em que o habeas data for impetrado originariamente perante os Tribunais Regionais Federais ou os Tribunais de Justiça dos Estados e do Distrito Federal (art. 108, I, 'c', da Constituição Federal e art. 20, I, 'a', ‘b’, ‘c' e ‘e' da Lei n. 9.507/1997), os recursos cabíveis serão o extraordinário e o recurso especial, consoante se façam presentes os pressupostos do art. 102, III, e do art. 105, III, da Constituição Federal, respectivamente, já que de 'causas decidias em única instância' se trata (v. n. 2.2 do Capítulo 11).

O Superior Tribunal de Justiça, vale frisar, só tem competência para julgar, em recurso ordinário, os acórdãos denegatórios de mandados de segurança impetrados originariamente naqueles Tribunais; impensável, pois, que, por analogia, reconheça-se àquele Tribunal competência similar àquela que o art. 102, II, 'a', da Constituição expressamente reservou ao Supremo Tribunal Federal em se tratando de habeas data ou de mandado de injunção." (BUENO, 2011, pp. 261/262).

${ }^{239}$ DIDIER JR. e CUNHA, 2010, p. 249.

${ }^{240}$ Não se incluem as causas em que é parte a União, os Estados e/ou o Distrito Federal, de um lado, e Estado estrangeiro ou organismo internacional, de outro, porque essas são de competência originária do Supremo Tribunal Federal (artigo 102, I, e, da Constituição Federal) e julgados pelo Pleno da Corte (artigo $5^{\circ}$, III, do Regimento Interno do Supremo Tribunal Federal), o que impede o exercício do duplo grau de jurisdição nestes casos, pois não há tribunal ou órgão fracionário de tribunal de superior hierarquia competente para julgar eventual recurso.
} 
Processo Civil), excepciona-se a regra geral do Código de Processo Civil, de cabimento de apelação, contra sentença (artigo 513), ou de agravo, contra decisão interlocutória (artigo $522)^{241}$. O Superior Tribunal de Justiça atua como verdadeira instância de segundo grau, suprimindo a atuação dos Tribunais Regionais Federais nestas causas ${ }^{242}$.

Neste caso, o recurso ordinário constitucional difere da subespécie relativa às ações constitucionais $^{243}$, sendo os seus requisitos de cabimento diversos ${ }^{244}$.

Tanto a sentença quanto as decisões interlocutórias são recorríveis por meio dessa subespécie recursal, que deve ser adequada ao provimento jurisdicional combatido e que guarda exata semelhança com a apelação e com o recurso de agravo, seja retido ou de instrumento $^{245}$. É o que dispõe o parágrafo único do artigo 539 do Código de Processo Civil, que dispõe que, nas causas internacionais há o recurso ordinário constitucional-apelação e o recurso ordinário constitucional-agravo, dependendo da decisão recorrida.

\subsection{Crime político}

Assim como as decisões proferidas em habeas corpus, as prolatadas em ações que versam sobre crime político não se referem ao estudo do Direito Processual Civil, mas sim ao Direito Processual Penal. Por isso, não será realizado um estudo detido do tema, conforme exposto na Introdução (Capítulo 1) desta dissertação ${ }^{246}$.

A previsão constitucional (artigo 102, II, b) de competência do Supremo Tribunal Federal $^{247}$ para o julgamento de recurso ordinário constitucional interposto contra decisão que julga crime político tem respaldo histórico na Carta de 1946, como tratado no item 4.2 deste trabalho.

Percebe-se, no entanto, que a Constituição Federal de 1988 deu ainda maior importância ao julgamento de recurso em crime político, pois não conferiu ao Superior

\footnotetext{
${ }^{241}$ SOUZA, 2007, p. 59.

${ }^{242}$ NERY JÚNIOR e NERY, 2009, p. 541.

${ }^{243}$ DIDIER JR. e CUNHA, 2010, pp. 250/251.

${ }^{244}$ AMORIM, 2005, p. 197.

${ }^{245}$ BARBOSA MOREIRA, 2010, p. 577.

${ }^{246}$ Crimes políticos são aqueles que "lesam ou põem em perigo a própria segurança interna ou externa do Estado.” (MIRABETE e FABBRINI, 2010, p. 122).

Segundo os citados autores, a Lei $n^{\circ} 7.170 / 83$ - Lei de Segurança Nacional - define como crimes políticos aqueles que ameaçam ou violam a integridade territorial, a segurança nacional, o regime representativo e democrático, a federação, o Estado de Direito e as pessoas dos chefes de Poderes da União $\left(\operatorname{artigo~} 1^{\circ}\right.$ ).

Há tipos penais específicos que caracterizam crimes políticos, os chamados crimes políticos puros ou próprios, com previsão nos artigos $8^{\circ}$ a 29 da referida lei, e crimes que, pela motivação do agente ou em razão da lesão real ou potencial aos bens jurídicos acima descritos, também são caracterizados como crimes políticos, os crimes políticos relativos ou impróprios (MIRABETE e FABBRINI, 2010, p. 122).

${ }^{247}$ Competência do Plenário, nos termos do artigo $6^{\circ}$, III, do Regimento Interno do Supremo Tribunal Federal.
} 
Tribunal de Justiça competência neste caso, como fez no habeas corpus e no mandado de segurança, processos muito mais ligados historicamente ao recurso ordinário constitucional. Esse tribunal superior não existia na vigência da Constituição de 1946, razão pela qual era natural que a competência fosse conferida ao Supremo Tribunal Federal.

O contexto político em que foi elaborada a Carta Magna de 1988, extremamente influenciado pela recém aprovada Lei da Anistia, explica o relevo dado ao crime político, entendendo por bem atribuir única e exclusivamente ao Supremo Tribunal Federal, guardião da Constituição Federal, o poder-dever de julgar recurso envolvendo essa matéria.

Diferentemente do que ocorre no recurso ordinário constitucional interposto nas ações constitucionais, nas causas referentes a crime político não é necessário que a decisão recorrida seja denegatória ou de única instância, proferida pelos tribunais superiores. É cabível o recurso ordinário constitucional contra qualquer decisão que verse sobre a matéria crime político.

Isso porque, neste caso, o cabimento do recurso tem razões eminentemente políticas e este é interposto diretamente ao Supremo Tribunal Federal contra decisão de juiz federal, como ocorre nas causas internacionais ${ }^{248}$.

${ }^{248}$ ORIONE NETO, 2009, pp. 429/430. 


\section{RECURSO ORDINÁRIO CONSTITUCIONAL - ASPECTOS PROCEDIMENTAIS}

O recurso ordinário constitucional, conforme já visto, é espécie recursal heterogênea ${ }^{249}$, que serve a diferentes finalidades dependendo da hipótese de cabimento. Também é um recurso tradicionalmente negligenciado pela doutrina e pela lei ${ }^{250}$, o que acaba por gerar diversas dúvidas práticas, sobretudo no que se refere ao seu procedimento.

Acaba-se suprindo a lacuna legislativa por meio da aplicação das regras referentes a outros recursos, em especial apelação e agravo. As semelhanças entre a apelação e o recurso ordinário constitucional - e também entre este e o agravo, quando recorrida decisão interlocutória - são maiores que as diferenças ${ }^{251}$, havendo inclusive respeitada doutrina que os equivale totalmente $\mathrm{e}^{252}$.

Porém, essa semelhança entre as espécies recursais não dispensa o estudo e a disciplina pormenorizada dos aspectos procedimentais do recurso ordinário constitucional, o que também reforça a sua autonomia.

Antes de se criticar o cabimento do recurso ordinário constitucional é preciso compreender a fundo a sua aplicação prática, até mesmo para confirmar que ele é uma espécie recursal diferente das demais previstas na Constituição Federal e no Código de Processo Civil, não simplesmente uma apelação ou um agravo com outra denominação.

\subsection{Requisitos de admissibilidade}

O artigo 540 do Código de Processo Civil dispõe que os requisitos de admissibilidade do recurso ordinário constitucional são os mesmos da apelação e do agravo, com as particularidades que os Regimentos Internos do Supremo Tribunal Federal e do Superior Tribunal de Justiça estabelecerem ${ }^{253}$. Ou seja, ao dizer que os requisitos de admissibilidade são os mesmos que os da apelação e do agravo, o Código de Processo Civil já aponta que eles não são o mesmo recurso, pois enumera três diferentes espécies recursais no artigo 540.

\footnotetext{
${ }^{249}$ AMENDOEIRA JR., 2012, p. 208.

${ }^{250}$ MENDONÇA LIMA, 1976, p. 216.

${ }^{251}$ MENDONÇA, 2006, p. 599.

252 "Em rigor, o recurso ordinário nada mais é do que uma apelação endereçada aos tribunais superiores, ressalvadas, é claro, as particularidades de cada recurso. Nas palavras de Teresa Arruda Alvim Wambier, 'o recurso ordinário é uma espécie de 'apelação' entre aspas'. A ratio essendi dessa assertiva e da própria existência do recurso ordinário assenta-se no princípio do duplo grau de jurisdição.” (ORIONE NETO, 2009, p. 426).

${ }^{253}$ AMORIM, 2005, pp. 203/204.
} 
Os requisitos de admissibilidade são os comuns aos recursos em geral, guardando maior semelhança com os dos recursos ordinários, entendidos como os em oposição aos recursos extraordinários ${ }^{254}$.

Anota-se que, nesta dissertação, a classificação para distinguir os requisitos de admissibilidade dos recursos será a clássica da doutrina nacional ${ }^{255}$, entre subjetivos e objetivos, e não a utilizada por JosÉ CARlos BARbosa MOREIRA, que os divide em intrínsecos e extrínsecos ${ }^{256}$.

\section{$\underline{6.1 .1 \quad \text { Subjetivos }}$}

Em razão das hipóteses de cabimento do recurso ordinário constitucional interposto em ação constitucional - decisão denegatória, conforme apontado anteriormente (item 5.1) - é especialmente do impetrante a legitimidade para interpor o recurso ${ }^{257}$.

O Ministério Público, como fiscal da lei, e o terceiro interessado também possuem legitimidade para recorrer por via dessa espécie recursal, respeitadas as disposições referentes aos recursos em geral $^{258}$.

Certo é que a autoridade coatora não poderá se valer do recurso ordinário constitucional, caso o writ tenha sido concedido, ainda que parcialmente. Poderá apenas interpor recurso extraordinário ou especial, dependendo das hipóteses de cabimento no caso concreto.

Por outro lado, no que toca ao recurso ordinário constitucional cabível nas causas internacionais, não há essa peculiaridade relativa à legitimidade para recorrer. Como não é preciso que a decisão recorrida seja denegatória, qualquer das partes pode se valer dessa via recursal, sem qualquer diferença em relação aos recursos em geral ${ }^{259}$.

\footnotetext{
${ }^{254}$ MIRANDA e PIZZOL, 2009, pp. 186/187.

255 "Subordina-se a admissibilidade do recurso a determinados requisitos ou pressupostos. Subjetivamente, estes requisitos dizem respeito às pessoas legitimadas a recorrer. Objetivamente, são pressupostos do recurso: $a$ ) a recorribilidade da decisão; $b$ ) a tempestividade do recurso; $c$ ) a singularidade do recurso; $d$ ) a adequação do recurso; $e$ ) o preparo; $f$ ) a motivação; $g$ ) a forma." (THEODORO JÚNIOR, 2009a, pp. 564/565).

${ }^{256}$ BARBOSA MOREIRA, 1968, p. 46.

${ }^{257}$ ROENICK, 1999, pp. 157/158.

${ }^{258}$ ASSIS, 2008, p. 94.

${ }^{259}$ Idem, p. 94.
} 


\section{$\underline{6.1 .2 \quad \text { Objetivos }}$}

De modo geral, os requisitos de admissibilidade objetivos do recurso ordinário constitucional são os mesmos do recurso de apelação ou do recurso de agravo, dependo da decisão recorrida.

O artigo 508 do Código de Processo Civil dispõe ser de 15 (quinze) dias o prazo para interposição do recurso ordinário constitucional e para a apresentação de contrarrazões. Esse prazo é o mesmo da apelação, devendo ser observadas as mesmas normas relativas à contagem de $\operatorname{prazo}^{260}$.

Questão interessante é a do prazo para a interposição de recurso ordinário constitucional contra decisão interlocutória proferida em causa internacional. Como, nesse caso, o recurso ordinário constitucional segue o procedimento do agravo, a doutrina aponta ser de $10(\mathrm{dez})$ dias o prazo para a sua interposição ${ }^{261}$, o que contraria, em tese, o disposto no artigo 508 do Código de Processo Civil.

De fato, esse é o melhor entendimento para o caso do recurso ordinário constitucional quando faz as vezes de agravo. Além de efetivar a garantia constitucional da igualdade, não tratando de forma diversa a recorribilidade das interlocutórias apenas em razão das partes nas chamadas causas internacionais, também se extrai, da interpretação do artigo 539, II, $b$ e parágrafo único do CPC, em conjunto com o artigo 522 do mesmo diploma legal, que o prazo para interposição dessa subespécie de recurso ordinário constitucional é mesmo o de 10 dias.

Nas ações constitucionais, quando o writ é parcialmente concedido, há uma exceção ao princípio da singularidade recursal ou unirrecorribilidade ${ }^{262}$. Por este princípio, é vedada a interposição de mais de um recurso, simultaneamente, contra a mesma decisão ${ }^{263}$.

\footnotetext{
${ }^{260}$ ROENICK, 1999, p. 159.

261 "É de 15 dias (art. 508, na redação da Lei no 8.950) o prazo de interposição do recurso ordinário, seja nos casos de competência do Supremo Tribunal Federal (art. 539, $\mathrm{n}^{\mathrm{o}} \mathrm{I}$ ), seja nos de competência do Superior Tribunal de Justiça (art. 539, $\mathrm{n}^{\circ}$ II). Ressalva-se, nestes últimos, o agravo (art. 539, parágrafo único): aí, o prazo é de 10 dias, conforme resulta da conjugação do dispositivo ora sob exame com o art. 522, caput, situado no Capítulo III deste Título, ao qual faz remissão expressa. Incidem as regras comuns sobre contagem, prorrogação, suspensão e interrupção.” (BARBOSA MOREIRA, 2010, p. 578).

No mesmo sentido: ASSIS, 2008, p. 94; CARREIRA ALVIM, 2011, p. 182; DIDIER JR. e CUNHA, 2010 , p. 251; LIMA, G., 2007, pp. 61.62; MARINONI e ARENHART, 2011, p. 555; NEGRÃO ET AL, 2012, p. 719; e SANTOS, 1996, pp. 12/13.

${ }^{262} \mathrm{Na}$ verdade, há exceção ao princípio da singularidade recursal apenas se o tomarmos conforme o conceito clássico, e já ultrapassado de que "as decisões judiciais somente são impugnáveis por meio de um único recurso. Para cada decisão não é permitida a interposição, ao mesmo tempo, de mais de um recurso.” (CHEIM JORGE, 2011, p. 221).

Sustentar a existência do princípio da singularidade com essa feição, no ordenamento jurídico vigente, que classifica os embargos de declaração como recurso e os entende oponíveis contra qualquer decisão, é praticamente impossível. Tanto que os doutrinadores que assim fazem encontram diversas exceções ao princípio, como os embargos de declaração (ASSIS, 2011, p. 90; MARINONI e ARENHART, 2011, p. 502; SOUZA,
} 
Ocorre que, nos casos expostos acima, será cabível a interposição de recurso ordinário constitucional, pelo impetrante, contra a parte denegatória da decisão, e de recurso especial e/ou de recurso extraordinário, pela autoridade coatora, contra a parcela concessiva da decisão, se cumpridos os requisitos de admissibilidade desses recursos ${ }^{264}$. O recurso ordinário constitucional e o recurso extraordinário terão julgamento conjunto, conforme o enunciado da Súmula no 299 do Supremo Tribunal Federal ${ }^{265}$.

Há apenas uma voz destoante - MARIA FÁtima VAQUERO RAMALHO LEYSER -, que entende que a interposição simultânea de recurso ordinário constitucional e de recurso extraordinário e/ou especial não é possível, justamente por haver violação à unirrecorribilidade $^{266}$. Sem razão, contudo, porque não se pode impedir que a parte da decisão concessiva da ação constitucional seja recorrida, pelas vias próprias, sob pena de violação à garantia constitucional de acesso à justiça.

A exceção ao princípio da singularidade se confirma pela impossibilidade de aplicação do princípio da fungibilidade recursal quando é interposto recurso especial ou recurso extraordinário contra a parte denegatória da decisão do writ $^{267}$. Tanto a doutrina ${ }^{268}$ quanto a

2011, pp. 69/70; e THEODORO JÚNIOR, 2009a, p. 569), o recurso ordinário constitucional quando a decisão é parcialmente concessiva e parcialmente denegatória do writ (SOUZA, 2011, pp. 70/71) e mesmo que ele só se refere a decisão interlocutória ou sentença, mas não a acórdão (CHEIM JORGE, 2011, p. 222).

Melhor aceitar a posição de que cada capítulo de um provimento judicial é um ato decisório autônomo e que o provimento com diferentes capítulos e um ato complexo (BARBOSA MOREIRA, 2010, p. 249; e KOZIKOSKI, 2011, p. 169), o que possibilita a interposição de mais de um recurso contra a mesma decisão, mas não de mais de um recurso contra um mesmo capítulo dessa decisão.

Contudo, também esse entendimento não está livre de críticas, pois os embargos de declaração, espécie recursal, continuam sendo cabíveis para sanar omissão da sentença, por exemplo, assim como a apelação pode servir a este mesmo fim (MARINONI e ARENHART, 2011, p. 502). Melhor seria entender que o princípio da unirrecorribilidade não vigora no ordenamento jurídico pátrio, ou adaptar o seu conceito de forma que não se façam tantas exceções. Porém, este não é o objeto da presente dissertação.

${ }^{263}$ THEODORO JÚNIOR, 2009a, p. 569.

${ }^{264}$ MIRANDA e PIZZOL, 2009, p. 187.

${ }^{265}$ Súmula $\mathrm{n}^{\circ}$ 299: "O recurso ordinário e o extraordinário interpostos no mesmo processo de mandado de segurança, ou de 'habeas corpus', serão julgados conjuntamente pelo Tribunal Pleno."

260 "O recurso ordinário não pode ser interposto concomitantemente com o recurso especial e extraordinário, em razão do princípio da singularidade, segundo o qual de cada decisão judicial recorrível é cabível um único tipo de recurso, vedado à parte ou interessado interpor mais de um tipo de recurso contra a mesma decisão." (LEYSER, 2000, p. 490).

${ }^{267}$ A jurisprudência também não admite a aplicação do princípio da fungibilidade quando, cabível recurso ordinário constitucional, é interposto recurso extraordinário ou recurso especial: STF, RMS n ${ }^{\circ}$ 25.354/MG, Rel. Min. Cármen Lúcia, $1^{a}$ Turma, j. 20/11/2007; STF, AgRg no RE no 423.817/DF, Rel. Min. Sepúlveda Pertence, $1^{a}$ Turma, j. 16/08/2005; STF, AgRg no AI no 410.552/CE, Rel. Min. Ellen Gracie, 2 ${ }^{\mathrm{a}}$ Turma, j. 14/12/2004; STJ, AgRg na MC n ${ }^{\circ}$ 9.397/ES, Rel. Min. Jane Silva, $6^{\mathrm{a}}$ Turma, j. 19/08/2008; STJ, Pet nº 1.047/RN, Rel. Min. José Arnaldo da Fonseca, $5^{\text {a }}$ Turma, j. 15/04/1999; e STJ, Pet no 983/SP, Rel. Min. Edson Vidigal, $5^{\text {a }}$ Turma, j. 01/09/1998.

${ }^{268}$ ASSIS, 2008, pp. 93/94; LIMA, J., 2008, p. 141; MEDINA e WAMBIER, 2008, p. 60; e MENDONÇA, 2006, p. 602; e THEODORO JÚNIOR, 1993, p. 09. 
jurisprudência $^{269}$, em especial a do Supremo Tribunal Federal (Súmula $\mathrm{n}^{\mathrm{o}} 272^{270}$ ), entendem se tratar de erro grosseiro a interposição de recurso especial ou de recurso extraordinário contra decisão denegatória de ação constitucional ${ }^{271}$.

A jurisprudência do Superior Tribunal de Justiça é vacilante quanto à aplicação do princípio da fungibilidade se, no lugar do recurso ordinário constitucional, houver sido interposta apelação. Em ações constitucionais, há entendimento nos dois sentidos ${ }^{272}$, enquanto em causas internacionais, em que as semelhanças entre a apelação e o recurso ordinário constitucional são mais acentuadas, entende não ser possível a aplicação do princípio ${ }^{273}$.

Quanto aos demais requisitos objetivos de admissibilidade não tratados especificamente - recorribilidade da decisão, preparo ${ }^{274}$, motivação ${ }^{275}$ e forma - nada há de peculiar em relação ao recurso ordinário constitucional, devendo todos ser cumpridos para que o recurso seja conhecido.

\section{$\underline{6.2 \quad \text { Efeito devolutivo }}$}

O recurso ordinário constitucional, como os demais recursos ordinários em sentido amplo, é dotado de amplo efeito devolutivo, ou seja, é admitida a rediscussão de questões de fato e de direito, sem qualquer impedimento ${ }^{276}$.

\footnotetext{
${ }^{269}$ STJ, RMS n $^{\mathrm{o}}$ 33.897/DF, Rel. Min. Herman Benjamin, 2a Turma, j. 11/10/2011; STJ, RMS n ${ }^{\mathrm{o}}$ 31.840/SP, Rel. Min. Mauro Campbell Marques, $2^{\text {a }}$ Turma, j. 04/11/2010; STJ, RMS no 25.369/SP, Rel. Min. Denise Arruda, $1^{\text {a }}$ Turma, j. 21/05/2009; e STJ, AgRg no RMS nº 26.690/RJ, Rel. Min. Eliana Calmon, $2^{\mathrm{a}}$ Turma, j. 14/04/2009.

${ }^{270}$ Súmula no 272 : "Não se admite como ordinário recurso extraordinário de decisão denegatória de mandado de segurança."

271 "7. Pelo objetivo do recurso ordinário constitucional, a parte vencida, em mandado de segurança e em habeas corpus, não pode interpor recurso extraordinário, ainda que se configure sua hipótese, em face do art. 101, inciso III, da Constituição Federal. Tem de utilizar-se daquele remédio, que é, aliás, mais vantajoso, por sua amplitude. (...)" (MENDONÇA LIMA, 1958, p. 60).

Deve-se apenas anotar que este texto é anterior à Constituição Federal de 1988.

${ }^{272}$ Entendendo ser aplicável o princípio da fungibilidade recursal: STJ, RMS n ${ }^{\circ} 36.805 / \mathrm{SP}$, Rel. Min. Laurita

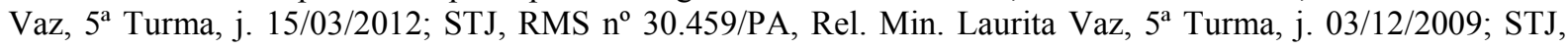
RMS $n^{\circ}$ 20.333/RN, Rel. Min. Laurita Vaz, $5^{\text {a }}$ Turma, j. 03/11/2009; e STJ, Pet $n^{\circ}$ 5.611/MG, Rel. Min. Napoleão Nunes Maia Filho, $5^{\text {a }}$ Turma, j. 16/08/2007 (este último proferido em sede de habeas corpus).

No sentido oposto: STJ, EDcl no RMS n ${ }^{\circ}$ 31.891/PR, Rel. Min. Teori Zavascki, $1^{\text {a }}$ Turma, j. 28/02/2012; STJ, AgRg no RMS no 33.449/SC, Rel. Min. Hamilton Carvalhido, $1^{\text {a }}$ Turma, j. 15/03/2011; STJ, RMS no 31.992/BA, Rel. Min. Herman Benjamin, $2^{\text {a }}$ Turma, j. 05/08/2010; e STJ, AgRg no RMS no 15.664/SP, Rel. Min. Honildo Amaral de Mello Castro, $4^{\mathrm{a}}$ Turma, j. 23/03/2010.

${ }^{273}$ STJ, AgRg no RO no 95/RS, Rel. Min. Maria Isabel Gallotti, $4^{\text {a }}$ Turma, j. 21/08/2012; STJ, AgRg no RO no 59/RJ, Rel. Min. Maria Isabel Gallotti, $4^{\mathrm{a}}$ Turma, j. 21/08/2012; STJ, AgRg no REsp n ${ }^{\circ}$ 1.135.494/RJ, Rel. Min. Marco Buzzi, 4ª Turma, j. 20/03/2012; e STJ, RO nº 77/SC, Rel. Min. Nancy Andrighi, $3^{\mathrm{a}}$ Turma, j. 14/04/2009. ${ }^{274}$ AMORIM, 2005, p. 95.

275 THEODORO JÚNIOR, 1993, p. 15.

${ }^{276}$ A doutrina é praticamente unânime nesse sentido: AMARAL SANTOS, 2010, p. 203; AMENDOEIRA JR., 2012, pp. 210/211; AMORIM, 2005, p. 206; ASSIS, 2008, p. 96; BARBI, 1991, pp. 228/229; BARBOSA MOREIRA, 2010, p. 578, 2012, p. 158; DINAMARCO, 2005, pp. 132/133; FUX, 2008, p. 936; KOZIKOSKI, 2011, p. 348; LASPRO, 1995, p. 156; LIMA, J., 2008, p. 145; MARCATO, 2006, p. 112; MARINONI e
} 
Não se aplicam as limitações impostas ao recurso extraordinário e ao recurso especial, recursos extraordinários em sentido amplo. Assim, não é exigido o prequestionamento das normas tratadas no recurso ${ }^{277}$ e é permitido aos tribunais superiores reexaminarem os fatos ${ }^{278}$, reinterpretarem cláusulas contratuais ${ }^{279}$ e analisarem matéria jurídica que não seria de sua alçada - direito federal constitucional para o Supremo Tribunal Federal e direito federal infraconstitucional para o Superior Tribunal de Justiça.

$\mathrm{Ou}$ seja, o Supremo Tribunal Federal pode analisar direito federal infraconstitucional ${ }^{280}$; assim como é permitido ao Superior Tribunal de Justiça o exame de direito federal constitucional ${ }^{281}$. Ambos também têm competência para julgar recurso ordinário constitucional que verse sobre direito estadual e/ou municipal ${ }^{282}$.

Em suma, qualquer norma jurídica ou matéria de fato pode ser rediscutida em sede de recurso ordinário constitucional ${ }^{283}$.

ARENHART, 2011, pp. 555/556; MEDINA e WAMBIER, 2008, p. 211; MENDONÇA, 2006, p. 599; MENDONÇA LIMA, 1958, p. 145; MIRANDA e PIZZOL, 2009, pp. 186/187; NERY JÚNIOR, 2004, p. 444; ORIONE NETO, 2009, p. 433; SANTOS, 1996, p. 31; SOUZA, 2007, pp. 44/46; e THEODORO JÚNIOR, 1993, p. 11.

Há apenas uma voz destoante, que, de maneira um tanto quanto confusa, considera que o recurso ordinário constitucional dirigido ao Supremo Tribunal Federal apenas poderia tratar de matéria federal constitucional e o dirigido ao Superior Tribunal de Justiça de matéria federal infraconstitucional (RODRIGUES, 1997, pp. 93/94).

A jurisprudência também tem este entendimento, conforme NEGRÃO et al (2012, p. 718):

"Art. 539: 8b. No recurso ordinário a devolução é total; nele não há as limitações do recurso especial (RSTJ 4/1.414: $4^{\mathrm{a}}$ T., RMS 32). Assim: 'O recurso em mandado de segurança tem natureza similar à apelação, devolvendo o conhecimento de toda a matéria alegada na impetração’ (RSTJ 94/362).

O recurso ordinário devolve ao STF ou ao STJ, a exemplo da apelação, o conhecimento 'de toda a matéria impugnada, que pode abranger todas as questões suscitadas e discutidas no processo de natureza constitucional ou não, e ainda que a sentença não as tenha julgado por inteiro' (RTJ 131/115).

'O recurso ordinário em mandado de segurança é apelo que possui natureza similar à apelação, devolvendo ao Tribunal o conhecimento de toda a matéria alegada na impetração, independentemente de eventual análise pelo Tribunal de origem, principalmente quando se tratar de matéria de ordem pública, que pode ser reconhecida a qualquer tempo' (STJ-5ª T., RMS 21.960-AgRg, rel. Min. Gilson Dipp, j. 17.10.06, DJU 13.11.06).

$\mathrm{O}$ recurso ordinário tem efeito translativo e permite ao tribunal ad quem enfrentar as matérias cognoscíveis de ofício, p. ex., para extinguir o processo em razão da ilegitimidade ad causam (STJ-2 ${ }^{\mathrm{a}}$ T., RMS 23.571, Min. Castro Meira, j. 6.11.07, DJU 21.11.07).".

${ }^{277}$ SOUZA, 2007, p. 47.

${ }^{278}$ ORIONE NETO, 2009, p. 433.

${ }^{279}$ NEGRÃO et al., 2012, p. 715.

${ }^{280}$ SIQUEIRA, 2001, pp. 36/37.

${ }^{281}$ Idem, p. 37.

${ }^{282}$ BARBI, 1991, pp. 228/229.

${ }^{283}$ Em texto escrito na vigência da Constituição Federal de 1946, ALCIDES DE MENDONÇA LiMA (1958, p. 60) conceitua bem essa abrangência das questões de Direito que podem ser objeto de análise em sede de recurso ordinário constitucional:

"Há os que asseveram, por sinal, que o recurso ordinário somente tem lugar quando, no mandado de segurança, está em jogo direito individual fundado em lei federal, pelas atribuições do Supremo Tribunal Federal, equiparando-o, neste ponto, ao recurso extraordinário, que somente tem lugar, como já acentuamos, face a uma violação da Constituição ou de lei federal. Entretanto, desde que a Constituição não distingue, não se pode restringir o alcance do preceito. Basta que seja denegado o mandado de segurança, pois a coletividade tem o máximo interesse em que não seja ferido direito líquido e certo dos indivíduos, qualquer que seja a norma invocada, podendo ser federal, estadual ou municipal.". 
Nada há de diferente entre o recurso ordinário constitucional e a apelação e o agravo no que se refere ao efeito devolutivo, tanto em sua extensão quanto em sua profundidade ${ }^{284}$.

\subsubsection{Aplicabilidade do artigo 515, $\S 3^{\circ}$, do CPC}

A única controvérsia jurisprudencial mais relevante é a aplicabilidade do disposto no artigo 515, $\S 3^{\circ}$, do Código de Processo Civil - teoria da causa madura - ao recurso ordinário constitucional, havendo posições opostas nos tribunais superiores competentes para julgar essa espécie recursal.

O Superior Tribunal de Justiça, de maneira geral, mas não unânime ${ }^{285}$, entende ser plenamente aplicável a teoria da causa madura ao recurso ordinário constitucional, dada a sua grande semelhança com o recurso de apelação e a garantia constitucional da duração razoável do processo (artigo $5^{\circ}$, LXXVIII, da Constituição Federal) ${ }^{286}$.

No entanto, o Supremo Tribunal Federal rechaçou expressamente a aplicação desse dispositivo legal ao recurso ordinário constitucional. $\mathrm{O}$ entendimento foi no sentido de que haveria a usurpação de competência dos demais tribunais superiores, órgãos que julgariam a ação constitucional originariamente, pelo Supremo Tribunal Federal, o que não seria permitido pela Carta Magna ${ }^{287}$.

\footnotetext{
${ }^{284}$ DINAMARCO, 2009a, 132/133.

285 "Art. 515: 12. Este dispositivo é aplicável em sede de recurso ordinário (art. 539). Assim: 'Reformando o acórdão que extingue o processo sem julgamento de mérito, cumpre ao STJ apreciar, desde logo, o mérito da impetração, se presentes os pressupostos do art. $515, \S 3^{\circ}$, do CPC, aplicável por analogia' (STJ-1 ${ }^{\text {a }}$ T., RMS 15.877, Min. Teori Zavascki, j. 18.5.04, DJU 21.6.04). No mesmo sentido: STJ-5 ${ }^{\mathrm{a}}$ T., RMS 17.891, Min. Laurita Vaz, j. 24.8.04, DJU 13.9.04; STJ-3 ${ }^{\mathrm{a}}$ T., RMS 20.871, Min. Gomes de Barros, j. 21.11.06, um voto vencido, DJU 1.8.07; STJ-2 ${ }^{\mathrm{a}}$ T., RMS 31.663, Min. Herman Benjamin, j. 5.10.10, DJ 2.2.11).

(...) Contra: 'A aplicação do art. $515, \S 3^{\circ}$, do $\mathrm{CPC}$ ao recurso ordinário, com a consequente transformação da competência recursal desta Corte em originária, incorreria em flagrante contrariedade ao texto constitucional e configuraria evidente usurpação da competência do Tribunal local para apreciação do mérito da demanda' (STJ$6^{\mathrm{a}}$ T., RMS 11.445, Min. Maria Thereza, j. 24.5.07, DJU 11.6.07). Ainda: STF-Pleno, RMS 26.959, Min. Menezes Direito, j. 26.3.09, maioria, DJ 15.5.09; STJ-5a T., RMS 23.554, Min. Laurita Vaz, j. 28.9.10, DJ 18.10.10; STF-RF 401/453 (2 T., RMS 27.368).” (NEGRÃO et al, 2012, p. 662, grifo dos autores).

286 "Corretamente decidiu o STJ, em 16.9.1997, R. Esp. no 129.057, in Rev. do STJ, vol. 104, pág. 505, que o recurso ordinário interposto pelos impetrantes contra a decisão denegatória da segurança abria ao órgão ad quem o conhecimento da decadência argüida pelo impetrado. O mesmo tribunal julgou aplicável por analogia ao recurso ordinário o disposto no art. $515, \S 3^{\circ}$, quanto á apelação: 18.5 .2004 , R.M.S. $\mathrm{n}^{\circ} 15.877$, in D.J. de 21.6.2004, pág. 163; 24.8.2004, R.M.S. no 17.891 in D.J. de 13.9.2004, pág. 264; 15.12.2005, R.M.S. no 11.222, in D.J. de 6.2.2006, pág. 288; 18.5.2006, R.M.S. ${ }^{\circ} 12.461$, in D.J. de 12.6.2006, pág. 498; 29.6.2006, R.M.S. n ${ }^{\circ}$ 21.208, in D.J. de 17.8.2006, pág. 321. (...)" (BARBOSA MOREIRA, 2010, p. 579).

287 "Art. 515: 12a. O STF entende inaplicável o art. $515 \S 3^{\circ}$ às hipóteses de recurso ordinário interposto contra acórdão do STJ que, em única instância, denega a segurança postulada pelo impetrante (art. 539-I), "visto tratarse de competência originária definida no próprio texto constitucional $(105, \mathrm{I}, \mathrm{b})$ '. Logo, 'deve-se prestigiar o STJ para apreciação do mérito da demanda, sem que haja o salto de grau jurisdicional' (STF-RT 834/176)." (NEGRÃO e GOUVÊA, 2009, p. 705).
} 
A doutrina, de maneira geral, entende ser correta a posição adotada pelo Superior Tribunal de Justiça ${ }^{288}$, até porque as regras referentes à apelação servem de base para os demais recursos, na falta de disciplina específica ${ }^{289}$. Há, inclusive, dura crítica ao entendimento do Supremo Tribunal Federal, por não haver justificativa plausível para a não adoção da teoria da causa madura ${ }^{290}$.

De fato, o posicionamento do Supremo Tribunal Federal sobre o tema não parece adequado, dado que o artigo 515, $\S 3^{\circ}$, do Código de Processo Civil não usurpa a competência do juízo a quo, mas sim permite que, em casos específicos, o juízo ad quem julgue o mérito da causa diretamente, em respeito à economia processual e à garantia constitucional da duração razoável do processo. A competência originária de um tribunal superior para julgar o feito em nada altera a aplicabilidade dessa garantia constitucional.

Dessa forma, não parece razoável que o próprio guardião da Constituição Federal não observe uma de suas garantias - duração do processo pelo tempo necessário.

${ }^{288}$ BARBOSA MOREIRA, 2010, p. 579; FRANCO, 2008, p. 704; LIMA, G., 2007, pp. 56 e 63; LUCON, 2008, p. 38; MENDONÇA, 2006, pp. 609/614; e SOUZA, 2011, pp. 585/586.

${ }_{289}^{289}$ LEONEL, 2007, p. 207.

290 "No âmbito do Supremo Tribunal Federal nenhuma razão suficiente se eleva à não-aplicação do princípio da causa madura ao recurso ordinário em mandado de segurança. Com efeito, já se sabe que a espécie recursal interposta perante a Corte Suprema tem cabimento em face de decisão denegatória proferido por Tribunal Superior no âmbito de sua competência originária. Também já se sabe que a locução decisão denegatória abriga tanto a decisão de mérito quanto a decisão meramente terminativa.

Assim, quando o tribunal superior promove a extinção do processo sem julgamento do mérito, em tese nenhum óbice se ergueria quanto á aplicação do $\S 3^{\circ}$ do art. 515. Não se estaria suprimindo instância já que a demanda foi devidamente submetida ao exame da instância originariamente competente, a qual concluiu sua participação, mediante a outorga da tutela jurisdicional considerada cabível à espécie - extinção do processo sem julgamento do mérito. Ao devolver-se a questão ao Supremo Tribunal Federal, em sede de recurso ordinário, plenamente legítimo seria o pedido de provimento do recurso, não somente para afastar a referida extinção como também para o julgamento, incontinenti, do mérito da demanda, na forma prevista no permissivo legal.

(...)

Sobreleva-se o exame da aplicação do princípio da Causa Madura sob o prisma de eventual mitigação da competência atribuída constitucionalmente aos Tribunais Superiores. Em verdade, nenhuma ofensa às regras de distribuição constitucional de competência resta configurada pela aplicação da teoria, porquanto, nesse caso, a ação foi ajuizada perante o Tribunal Superior competente, que exauriu seu trabalho ao julgar extinto o processo. $\mathrm{O}$ fato de não ter ingressado no exame do mérito decorreu, obviamente, do conteúdo meramente terminativo de sua decisão. A restituição dos autos ao tribunal superior para exame do mérito acabaria por atentar contra os princípios da celeridade e economia processual, mormente considerando que, se for denegatória a decisão de mérito proferida pelo Tribunal, a questão será totalmente restituída ao Supremo Tribunal Federal, por força da ampla devolutividade do recurso ordinário. Portanto, o julgamento, incontinenti, do mérito pelo Pretório Excelso proporciona a aceleração do resultado da demanda - que viria apenas em momento posterior, caso fosse determinada a baixa dos autos para apreciação do mérito pelo tribunal. A incidência do princípio da Causa Madura tem o condão de agilizar o resultado prático da ação.

(...)

Com efeito, se é verdadeira a afirmativa de que o $\S 3^{\circ}$ do art. 515 do CPC não pode ser aplicado em sede de recurso ordinário em mandado de segurança perante o Supremo Tribunal Federal, por não ser possível 'mitigar' a competência do Superior Tribunal de Justiça, do mesmo modo não seria viável ao Superior Tribunal de Justiça aplicar o referido preceito, em sede de recurso ordinário em mandado de segurança, por também configurar 'afronta' à competência originária dos Tribunais Regionais Federais e aos Tribunais dos Estados, do Distrito Federal e Territórios. (...)” (MENDONÇA, 2006, pp. 610/613). 


\title{
$\underline{6.3 \quad \text { Efeito suspensivo }}$
}

Este talvez seja o ponto mais controvertido em relação ao recurso ordinário constitucional: ser ele dotado ou não de efeito suspensivo.

Efeito suspensivo, na precisa conceituação de NELSON NERY JÚNIOR é:

\begin{abstract}
O efeito é uma qualidade do recurso que adia a produção dos efeitos da decisão impugnada assim que interposto o recurso, qualidade essa que perdura até que transite em julgado a decisão sobre o recurso. Pelo efeito suspensivo, a execução do comando emergente da decisão impugnada não pode ser efetivada até que seja julgado o recurso. A decisão que ainda não havia produzido efeitos, porque não prolatada, continua a não produzi-los pelo efeito suspensivo do recurso que não pode, por certo, suspendê-la. Na verdade, a suspensividade diz mais de perto com a recorribilidade do que propriamente com o recurso. ${ }^{291}$.
\end{abstract}

Atribuir efeito suspensivo ou não a recurso é opção política do legislador ${ }^{292}$, pois este não é essencial à caracterização do recurso ${ }^{293}$.

O Código de Processo Civil não estabelece uma regra geral - apesar de alguns autores afirmarem que ela existe, tanto no sentido de os recursos serem, em regra, dotados de efeito suspensivo $^{294}$, quanto no sentido de não o serem ${ }^{295}$ - sobre o efeito suspensivo das variadas espécies recursais. É expresso em relação à apelação (artigo 520); ao agravo, ao recurso especial e ao recurso extraordinário (artigo 497); mas silencia no que se refere aos embargos de declaração, aos embargos infringentes, aos embargos de divergência e ao recurso ordinário constitucional. Daí decorre a divergência sobre os efeitos do recurso ordinário constitucional.

Para aqueles que consideram que, no silêncio da lei, o recurso tem efeito suspensivo, a questão se resolve com simplicidade: o recurso ordinário constitucional é dotado de efeito suspensivo.

Todavia, como não se considera haver uma regra geral no nosso ordenamento jurídico, refuta-se essa conclusão.

\footnotetext{
${ }^{291}$ NERY JÚNIOR, 2004, pp. 445/446.

292 BUENO, 2006, p. 70.

${ }^{293}$ LEONEL, 2006, p. 504.

${ }^{294}$ ASSIS, 2008, pp. 98/99; BARBOSA, 1990, pp. 63/64; BARBOSA MOREIRA, 2010, p. 578, 2012, p. 123; DIDIER JR. e CUNHA, 2010, p. 82; FREITAS CÂMARA, 2008, p. 73; FUX, 2008, p. 936; GOMES JÚNIOR, 2003, p. 486; MENDONÇA, 2006, p. 615; MIRANDA e PIZZOL, 2009, p. 187; e NERY JÚNIOR, 2004, p. 448.

Tradicionalmente os recursos são dotados de efeito suspensivo no sistema de civil law (COUTURE, 1958, p. 341).

${ }^{295}$ AMENDOEIRA JR., 2012, p. 23; DINAMARCO, 2009a, p. 146; e SOUZA, 2011, p. 58.
} 
Há entendimento no sentido de que o recurso ordinário constitucional tem efeito suspensivo por força do disposto no artigo 540 do Código de Processo Civil, que determina lhe serem aplicáveis o procedimento no juízo a quo e os requisitos de admissibilidade próprios à apelação ${ }^{296}$.

Não obstante o grande conhecimento dos defensores dessa posição, não se concorda com ela, pois requisitos de admissibilidade e efeitos do recurso não se confundem, não havendo como resolver a questão pelo disposto no artigo 540 do Código de Processo Civil ${ }^{297}$.

Também se justifica o efeito suspensivo ao recurso ordinário constitucional para preservar os direitos do impetrante ${ }^{298}$. Contudo, se ele só tem cabimento contra decisão denegatória, não há direito do impetrante a ser preservado.

Ademais, caso o recurso ordinário constitucional seja interposto contra decisão denegatória de mandado de segurança em que havia sido concedida a liminar, o fato de o recurso ter efeito suspensivo não significa que ele restabelece a decisão. Isso porque, em sede mandamental, a liminar tem sempre caráter precário, sendo revogada pela decisão final em qualquer hipótese $^{299}$. O Supremo Tribunal Federal editou Súmula nesse sentido ${ }^{300}$.

Partindo-se do pressuposto que, nas ações constitucionais, o recurso ordinário constitucional só é cabível contra decisão denegatória, parte da doutrina preceitua que não haveria efeitos da decisão recorrida a serem suspensos, com exceção da condenação acessória. Por isso, o recurso ordinário constitucional não seria dotado de efeito suspensivo ${ }^{301}$.

$\mathrm{Na}$ verdade, não é apenas pelo fato de as decisões recorridas por meio do recurso ordinário constitucional serem denegatórias que ele não é dotado de efeito suspensivo, já que, denegatória a decisão, não há decisão a ser executada; mas também porque é da natureza das

\footnotetext{
296 "A disciplina dos efeitos da apelação rege também os do recurso ordinário, que, mutatis mutandis, realiza a missão daquela nos casos em que é admissível (art. 540)." (DINAMARCO, 2009a, p. 147).

No mesmo sentido: BUENO, 2006, pp. 76/77; MENDONÇA, 2006, p. 615; e SOUZA, 2007, p. 67.

Com entendimento similar, mas concluindo que "o recurso ordinário, também de índole constitucional, como o são o extraordinário e o especial, possui 'duplo efeito', e isso por não haver sido incluído no $\S 2^{\circ}$ do art. 524, e por sua admissibilidade obedecer às regras da apelação" (ROENICK, 1999, p. 161).

297 "O recurso ordinário constitucional (CF 102 II e 105 II) não é recebido no efeito suspensivo. Primeiro porque a LR 34 e o CPC 540 determinam que sejam aplicáveis ao recurso ordinário as regras do CPC relativas à admissibilidade e procedimento da apelação, inconfundíveis com os efeitos da interposição do recurso. (...)" (NERY JÚNIOR, 2004, p. 449).

No mesmo sentido: ORIONE NETO, 2009, p. 434.

${ }^{298}$ LACOMBE, 1957, p. 502.

Com toda justiça, este artigo foi escrito em 1957, na vigência da Constituição de 1946, com uma perspectiva bastante diferente da atual sobre a eficácia das decisões em sede de mandado de segurança.

${ }^{299}$ THEODORO JÚNIOR, 1993, p. 15.

${ }^{300}$ Súmula no 405 : "Denegado o mandado de segurança pela sentença, ou no julgamento do agravo, dela interposto, fica sem efeito a liminar concedida, retroagindo os efeitos da decisão contrária".

${ }^{301}$ EVANGELISTA e SOUZA, 2005, p. 596.
} 
ações constitucionais a execução imediata das decisões ${ }^{302}$, nos termos dos artigos 14 e 15 da Lei ${ }^{\circ} 12.016 / 2009$, que regula o mandado de segurança e o mandado de injunção, e artigo 15 da Lei $n^{\circ}$ 9.507/1997, que trata do habeas data.

Pode, excepcionalmente, ser concedido efeito suspensivo, que abarcaria apenas a condenação ao pagamento das verbas de sucumbência, ou a antecipação dos efeitos da tutela recursal ao recurso ordinário constitucional nesses casos, por meio de ação cautelar incidental $^{303}$ ou mesmo por meio de requerimento de antecipação dos efeitos da tutela recursal formulado no próprio recurso ${ }^{304}$.

Mas, nesses casos, tanto o recurso ordinário constitucional quanto a apelação não são dotados de efeito suspensivo. A natureza da causa, em conjunto com o fato de ter sido denegado o pedido inicial, afasta o efeito suspensivo do recurso interposto contra a sentença, não uma característica específica do recurso ordinário constitucional.

\footnotetext{
302 “A meu ver, os efeitos do recurso ordinário dependem da natureza do acórdão impugnado, pois, se for, por exemplo, um recurso em mandado de segurança, o efeito será apenas devolutivo, por aplicação extensiva do disposto no $\S 3^{\circ}$ do art. 14 da Lei 12.016/09. Aliás, não teria sentido que um acórdão proferido em mandado de segurança, só pelo fato de ser originário - da competência do STF ou do STJ - pudesse ser desde logo cumprido. O mesmo se diga do recurso em habeas data, por aplicação do disposto no parágrafo único do art. 15 da Lei 9.507/97." (CARREIRA ALVIM, 2011, pp. 179/180).

CÁsSio SCARPINELla BuENo (2011, p. 263) diverge desse entendimento, apontando que a lei determina que apenas os recursos interpostos contra decisões concessivas dos writs não seriam dotados de efeito suspensivo, não podendo essa restrição ser também estendida para os recursos interpostos para combater decisões denegatórias: "Nos casos em que o recurso ordinário é interposto em mandado de segurança, habeas data e mandado de injunção, a melhor interpretação é a de que o recurso ordinário tem efeito suspensivo pelo prevalecimento da regra específica do mandado de segurança, qual seja, o art. $14, \S 1^{\circ}$, da Lei 12.016/2009, que serve também para o mandado de injunção, em face do parágrafo único do art. 24 da Lei 8.038/1990, e do habeas data, o art. 15, parágrafo único, da Lei n. 9.507/1997. Nestes dois dispositivos, a ausência do efeito suspensivo dá-se na hipótese de decisão concessiva da ordem, admitindo-se, consequentemente, a execução provisória do julgado, situação oposta àquela que rende ensejo ao recurso ordinário, que pressupõe decisão denegatória ao impetrante (v. n. 2.1, supra)".

${ }^{303}$ SOUZA, 2011, p. 609.

O Supremo Tribunal Federal julga normalmente as cautelares ajuizadas para esse fim, não aplicando as Súmulas $\mathrm{n}^{\circ} \mathrm{s} 634$ e 635, que determinam não ser possível o ajuizamento de cautelar perante o Supremo Tribunal Federal para conceder efeito suspensivo a recurso extraordinário pendente de exame de admissibilidade pelo juízo a quo, mas sim ser competente o juízo a quo para julgar essa cautelar: STF, AC 813/DF, Rel. Min. Cezar Peluso, ${ }^{\text {a }}$ Turma, j. 13/06/2006; Pet 2.644/DF, Rel. Min. Moreira Alves, $1^{\text {a }}$ Turma, j. 16/04/2002; e Pet 1.941/SP, Rel. Min. Moreira Alves, $1^{\text {a }}$ Turma, j. 28/03/2000.

Já o Superior Tribunal de Justiça tem entendimento controvertido. Há julgados que, assim como o Supremo Tribunal Federal faz, analisam normalmente as cautelares (p. ex.: STJ, AgRg na MC n ${ }^{\text {o } 19.697 / P A, ~ R e l . ~ M i n . ~}$ Antonio Carlos Ferreira, 4a Turma, j. 16/08/2012; STJ, AgRg na MC n ${ }^{\circ}$ 19.621/RJ, Rel. Min. Nancy Andrighi, $3^{\mathrm{a}}$ Turma, j. 16/08/2012; STJ, AgRg na MC no 19.057/SP, Rel. Min. Marco Buzzi, 4a Turma, j. 02/08/2012; e STJ, AgRg na MC no 19.361/PR, Rel. Min. Teori Zavascki, $1^{\text {a }}$ Turma, j. 26/06/2012); e outros que, apesar de entenderem aplicáveis as mencionadas Súmulas n ${ }^{\circ} \mathrm{s} 634$ e 635 do STF, analisam o mérito da cautelar (STJ, MC $n^{o}$ 19.763/MG, Rel. Min. Humberto Martins, $2^{\text {a }}$ Turma, j. 06/11/2012; STJ, RCDESP na MC nº 19.359/PI, Rel. Min. Arnaldo Esteves Lima, $1^{\text {a }}$ Turma, j. 16/08/2012; STJ, AgRg na MC n ${ }^{\circ}$ 16.529/AL, Rel. Min. Laurita Vaz, $5^{\text {a } T u r m a, ~ j . ~ 21 / 09 / 2010 ; ~ e ~ S T J, ~ A g R g ~ n o ~ A g R g ~ n a ~ M C ~ n o ~ 17.057 / R N, ~ R e l . ~ M i n . ~ P a u l o ~ d e ~ T a r s o ~ S a n s e v e r i n o, ~} 3^{\text {a }}$ Turma, j. 02/09/2010).

${ }^{304}$ Consideram que a concessão de efeito suspensivo ou a antecipação dos efeitos da tutela recursal é ope judicis no ordenamento jurídico brasileiro: BUENO, 2006, p. 75; e LEONEL, 2006, pp. 521/522.
} 
Por outro lado, em relação às causas internacionais, em que não é preciso que a decisão recorrida seja denegatória, o fato de o recurso ordinário constitucional ser ou não capaz de suspender os efeitos do provimento jurisdicional atacado se mostra bastante importante.

Há parcela considerável de autores que, nesse caso, com razão, equipara totalmente as espécies recursais em relação aos seus efeitos, ensinando que o disposto no artigo 520 do Código de Processo Civil também é válido para o recurso ordinário constitucional ${ }^{305}$.

Se o recurso ordinário constitucional, nas causas internacionais, se revela uma exceção à regra geral de cabimento da apelação, pela especialidade e cuidados adicionais que o constituinte concedeu a esse tipo de demanda, não faz sentido que a sentença que a julgue não seja recorrida por recurso dotado de efeito suspensivo, como a maior parte das sentenças ${ }^{306}$.

Assim, nas ações constitucionais, o recurso ordinário constitucional, assim como a apelação, não é dotado de efeito suspensivo, em razão da natureza da causa julgada, não de particularidade da espécie recursal; e, nas causas internacionais, ele segue a mesma regra que o apelo, sendo dotado de suspensividade, com exceção das hipóteses previstas nos incisos do artigo 520 do Código de Processo Civil.

Quando o recurso ordinário constitucional fizer as vezes do recurso de agravo, seguese a mesma lógica desta espécie recursal, podendo o relator conceder-lhe o efeito suspensivo, desde que demonstrados os requisitos legais.

\subsection{Procedimento perante o juízo a quo}

O já mencionado artigo 540 do Código de Processo Civil também determina que o procedimento do recurso ordinário constitucional perante o juízo a quo será o mesmo aplicável aos recursos de apelação e de agravo.

Nota-se, porém, que, no que se refere ao recurso ordinário constitucional contra decisão interlocutória, na modalidade de instrumento, cabível nas causas internacionais (item 5.2 desta dissertação), não há procedimento perante o juízo a quo, pois este recurso é interposto diretamente no juízo ad quem, como no agravo de instrumento (artigo 524 do

\footnotetext{
${ }^{305}$ AMENDOEIRA JR., 2012, p. 214; ASSIS, 2011, p. 679; BUENO, 2011, p. 264; e CHEIM JORGE, 2011, pp. 347/348; e SOUZA, 2007, p. 57.

${ }^{306}$ LIMA, G., 2007, p. 63.
} 
Código de Processo Civil), sem qualquer participação do juízo prolator da decisão recorrida no procedimento de interposição do recurso ${ }^{307}$.

\subsubsection{Duplo exame de admissibilidade}

Por ser interposto perante o juízo a quo, o recurso ordinário constitucional, quando faz as vezes de apelação e de agravo retido, está sujeito ao duplo exame de admissibilidade primeiro pelo juízo de origem, que proferiu a decisão recorrida, e depois pelo juízo ad quem, que tem competência para processar e julgar o recurso -, assim como ocorre com a $\operatorname{apelação~}^{308}$.

A justificativa para o duplo exame de admissibilidade no recurso ordinário constitucional é a mesma usada na apelação: filtrar os recursos que são examinados pela instância superior, impedindo que aqueles sem as mínimas condições de serem conhecidos sigam para análise do juízo ad quem ${ }^{309}$.

Como o procedimento perante o juízo a quo é o mesmo aplicável à apelação, também é possível a aplicação do disposto no artigo 518, $\S 1^{\circ}$, do Código de Processo Civil - a chamada súmula impeditiva de recursos - ao recurso ordinário constitucional, conforme já decidiu o Supremo Tribunal Federal ${ }^{310}$.

Quando o recurso ordinário constitucional é interposto contra decisão interlocutória e formam-se autos apartados - modalidade de instrumento -, por ser dirigido diretamente ao órgão ad quem, o juízo de admissibilidade é único.

\subsubsection{Interposição perante o juízo a quo - Órgão competente}

Conforme acima explicitado, o recurso ordinário constitucional, quando interposto no juízo a quo, deve passar por um duplo exame de admissibilidade, como se dá com o recurso

\footnotetext{
${ }^{307}$ BARBOSA MOREIRA, 2010, p. 579.

${ }^{308}$ SOUZA, 2007, p. 52.

309 BARBOSA MOREIRA, 1968, p. 114.

310 “AGRAVO REGIMENTAL EM RECLAMAÇÃO. ALEGAÇÃO DE USURPAÇÃO DE COMPETÊNCIA DESTA CORTE. RECURSO ORDINÁRIO EM MANDADO DE SEGURANÇA. JUÍZO DE ADMISSIBILIDADE. INVASÃO DO MÉRITO DO RECURSO. INOCORRÊNCIA. AGRAVO IMPROVIDO. I - O Código de Processo Civil dispõe que, quanto à admissibilidade de recurso ordinário, devem-se observar os procedimentos previstos para a apelação e que a mesma não será recebida quando estiver em conformidade com Súmula do STJ ou do STF.

II - Verificou-se, no juízo de admissibilidade, que o acórdão estava em consonância com a Súmula 267 desta Corte, e, aplicando-se o disposto do Código de Processo Civil, negou-se seguimento ao recurso ordinário.

III - O recurso cabível, no caso, seria o agravo de instrumento e não a reclamação." (STF, AgRg na Rcl no 5.153/DF, Rel. Min. Ricardo Lewandowski, Tribunal Pleno, j. 11/10/2007)
} 
de apelação. No entanto, a doutrina é bastante divergente no que se refere à autoridade integrante do juízo recorrido que seria competente para realizar esse exame.

A primeira corrente doutrinária entende que o órgão competente para realizar o exame de admissibilidade do recurso ordinário constitucional no juízo a quo é o Presidente ou o Vice-Presidente do tribunal que proferiu a decisão recorrida ${ }^{311}$. A justificativa para esse entendimento é que os regimentos internos poderiam regular essa competência ${ }^{312}$ e que não haveria disposição legislativa específica sobre o tema ${ }^{313}$, sendo aplicável a regulamentação referente aos recursos extraordinários, de competência do Supremo Tribunal Federal e do Superior Tribunal de Justiça ${ }^{314}$.

Já a outra corrente aponta que o relator da ação constitucional de competência originária do tribunal ou o juiz federal que processa e julga a causa internacional em primeira instância seriam, conforme o caso, os responsáveis pela realização do primeiro exame de admissibilidade do recurso ordinário constitucional ${ }^{315}$. Por esse entendimento, não seria lícito aos regimentos internos dos tribunais modificarem essa competência, sendo que o disposto no artigo 541, caput, do Código de Processo Civil só teria aplicação ao recurso especial e ao recurso extraordinário ${ }^{316}$.

Entende-se correta a segunda posição, pois o artigo 540 do Código de Processo Civil expressamente dispõe que o recurso ordinário constitucional seguirá o mesmo procedimento no juízo de origem que a apelação e, como esta é endereçada a quem proferiu a decisão recorrida - o juiz da causa, nos termos do artigo 514, caput, do Código de Processo Civil -, também deverá o ser o recurso ordinário constitucional. Não é permitido que os regimentos internos dos tribunais contrariem lei ordinária federal, que disciplina matéria procedimental, nos termos do artigo 96, I, $a$, da Constituição Federal ${ }^{317}$.

\footnotetext{
${ }^{311}$ DIDIER JR. e CUNHA, 2010, p. 247; LIMA, G., 2007, pp. 56/57; e LIMA, J., 2008, p. 141; MARINONI e ARENHART, 2011, p. 556; MENDONÇA, 2006, p. 614; e SOUZA, 2011, pp. 620/621.

${ }^{312}$ DIDIER JR. e CUNHA, 2010, p. 247.

${ }^{313}$ Originalmente, o artigo 584 do Anteprojeto do atual Código de Processo Civil, elaborado por ALFREDo BUZAID, previa que o Presidente do Tribunal a quo era o responsável pelo exame de admissibilidade do recurso ordinário constitucional.

${ }^{314}$ MENDONÇA, 2006, p. 614.

${ }^{315}$ AMORIM, 2005, pp. 204/205; ASSIS, 2008, p. 101; e ROENICK, 1999, p. 158.

${ }^{316}$ ASSIS, 2008, p. 101.

317 "Art. 96. Compete privativamente:

I - aos tribunais:

a) eleger seus órgãos diretivos e elaborar seus regimentos internos, com observância das normas de processo e das garantias processuais das partes, dispondo sobre a competência e o funcionamento dos respectivos órgãos jurisdicionais e administrativos;"
} 
6.4.3 Recurso cabível contra decisão do juízo a quo que nega seguimento ao recurso ordinário constitucional

Há grande divergência doutrinária e jurisprudencial sobre qual seria o recurso cabível contra a decisão, proferida pelo juízo a quo, que nega seguimento a recurso ordinário constitucional.

São três as posições da doutrina e da jurisprudência: (i) cabimento de agravo interno/regimental; (ii) cabimento de agravo de instrumento, na forma do artigo 522 do Código de Processo Civil; e (iii) cabimento de agravo previsto no artigo 544 do Código de Processo Civil.

A jurisprudência do Superior Tribunal de Justiça tem entendimento majoritário no sentido de ser cabível o agravo regimental, apesar de já haver julgados que admitem a interposição de agravo de instrumento e do agravo previsto no artigo 544 do Código de Processo Civil ${ }^{318}$.

Pelo entendimento majoritário do Superior Tribunal de Justiça, seria possível interpor recurso especial contra o acórdão que negasse provimento a esse agravo interno. Esse entendimento repele a aplicação do artigo 522 do Código de Processo Civil, pois as decisões

${ }^{318}$ Citando NEGRÃo et al (2012, p. 717, grifo dos autores):

“Art. 539: 5b. Qual o recurso cabível contra a decisão de inadmissão do recurso ordinário pelo tribunal local?

- No sentido de que 'é o agravo regimental, a ser julgado por órgão fracionário daquele pretório, e não agravo de instrumento perante esta Corte': STJ-6 ${ }^{\mathrm{a}}$ T., AI 59.202-AgRg, Min. Fernando Gonçalves, j. 18.3.97, DJU 22.4.97. Também considerando cabível o agravo regimental: STJ-5 ${ }^{\mathrm{a}}$ T., AI 388.317-AgRg, Min. Jorge Scartezzini, j. 2.4.02, DJU 20.5.02. Afirmando o descabimento do agravo de instrumento nessas circunstâncias, 'porque inocorrentes as hipóteses autorizadoras dos artigos 539, § ún. E 544 do CPC ou ainda do art. 522': STJ$2^{\mathrm{a}}$ T., AI 455.453-AgRg, Min. Eliana Calmon, j. 20.3.02, DJU 7.4.03. Ainda: 'A teor do disposto no art. 544 do CPC, o agravo de instrumento, no STJ, é recurso cabível apenas em face de decisão que não admite recurso extraordinário ou especial, não sendo possível sua interposição contra decisão que nega seguimento a recurso ordinário' (STJ-5ª T., AI 554.328-AgRg-AgRg, Min. Arnaldo Esteves, j. 15.9.05, DJU 24.10.05). No mesmo sentido: STJ-6 ${ }^{\mathrm{a}}$ T., AI 715.151-AgRg, Min. Hamilton Carvalhido, j. 2.2.06, DJU 6.3.06; STJ-4a T., AI 268.062AgRg, Min. Aldir Passarinho Jr., j. 13.11.01, DJU 14.10.02.

- No sentido de que é o agravo de instrumento previsto no art. 522, a ser interposto diretamente perante o tribunal ad quem: STJ-4 ${ }^{\mathrm{a}}$ T., AI 377.099, Min. Sálvio de Figueiredo, dec. Mon., DJU 14.6 .02 (bem fundamentada e com apoio doutrinário). Milita a favor desse entendimento a equiparação do recurso ordinário à apelação: o indeferimento do processamento daquele tem a mesma natureza do não recebimento desta, e se esse ato é impugnável pelo agravo previsto no art. 522 aquele também deve sê-lo. 'Por tratar-se de questão eminentemente processual não pacificada, em razão de razoável dúvida objetiva quanto ao recurso cabível, com base no princípio do acesso à justiça, deve-se admitir a interposição do presente agravo de instrumento com fundamento no art. 522 do CPC' (STJ-2a T., Ag 1.340.963-AgRg, Min. Castro Meira, j. 15.3.11, DJ 25.3.11).

'O recurso cabível contra decisão que não admite recurso ordinário em mandado de segurança dirigido ao Supremo Tribunal Federal é o agravo de instrumento e não o agravo regimental. Impossibilidade de aplicação do princípio da fungibilidade recursal, uma vez que ele pressupõe a existência de dúvida objetiva, o que não ocorre in casu' (STJ-Corte Especial, MS 15.806-RO-AgRg, Min. Felix Fischer, j. 12.5.11, DJ 6.6.11).

- No sentido de que é o agravo previsto no art. 544: 'Aplicação da analogia e do princípio da adequação das formas' (STJ-1 ${ }^{\mathrm{a}}$ T., AI 1.075.509-AgRg, Min. Teoria Zavascki, j. 4.11.08, um voto vencido, DJ 4.2.09; bem fundamentado e com apoio doutrinário).”. 
recorríveis por essa via recursal seriam as proferidas apenas pelo juiz de primeiro grau e não por desembargador; e afasta o cabimento do artigo 544 do Código de Processo Civil porque não se estaria diante de recurso extraordinário ou recurso especial.

Entre os doutrinadores, essa posição é sustentada, somente na hipótese de recurso ordinário constitucional endereçado ao Superior Tribunal de Justiça, apenas por LUIZ GUILHERME MARINONI e SÉRGIO CRUZ ARENHART ${ }^{319}$, mas não há como concordar com ela.

Nem mesmo o próprio Regimento Interno do Superior Tribunal de Justiça está de acordo com ela, pois em seu artigo 270 , parágrafo único ${ }^{320}$, dispõe que o recurso cabível contra a decisão deste tribunal que negue seguimento a recurso ordinário constitucional é o agravo de instrumento interposto diretamente perante o Supremo Tribunal Federal.

Os regimentos internos de alguns tribunais, como o do Tribunal Regional Federal da $3^{\mathrm{a}}$ Região (artigo 274, parágrafo único ${ }^{321}$ ) e do Tribunal Regional Federal da $1^{\text {a }}$ Região (artigo 320 c.c. artigos 299 e $300^{322}$ ), também são contrários a esse entendimento, o que acaba por dificultar muito o exercício da faculdade de recorrer.

\footnotetext{
${ }^{319}$ MARINONI e ARENHART, 2011, pp. 556/557.

Quando o destinatário do recurso ordinário constitucional é o Supremo Tribunal Federal, os autores consideram que o recurso cabível contra a decisão do juízo a quo que nega seguimento ao recurso é o agravo de instrumento, nos termos do artigo 522 do Código de Processo Civil (p. 557).

320 “Art. 270. O Presidente do Tribunal decidirá a respeito da admissibilidade do recurso.

Parágrafo único. Da decisão que não admitir o recurso, caberá agravo de instrumento para o Supremo Tribunal Federal."

321 “Art. 274 - Interposto o recurso, os autos serão conclusos ao Vice-Presidente do Tribunal, que apreciará seu cabimento.

Parágrafo único - Contra a decisão do Vice-Presidente que negar seguimento ao recurso, caberá agravo para o Superior Tribunal de Justiça, observados os requisitos de admissibilidade e procedimento previstos no Título VIII, Capítulo II, Seção II, deste Regimento.”

322 "Art. 320. O agravo de instrumento contra decisão que nega seguimento a recurso para outro tribunal será interposto e processado na forma prevista nos arts. 299 e 300 deste Regimento.

(...)

Art. 299. O agravo de instrumento de decisão que não admite recurso especial ou extraordinário será interposto, no prazo de dez dias, por petição que conterá:

I - a exposição do fato e do direito;

II - as razões do pedido de reforma da decisão.

$\S 1^{\circ} \mathrm{O}$ agravo de instrumento será instruído com as peças apresentadas pelas partes, devendo dele constar, obrigatoriamente, cópias do acórdão recorrido, da certidão da respectiva intimação, da petição de interposição do recurso denegado, das contrarrazões, da decisão agravada, da certidão da respectiva intimação e das procurações outorgadas aos advogados do agravante e do agravado. As cópias das peças do processo poderão ser declaradas autênticas pelo próprio advogado, sob sua responsabilidade pessoal.

$\S 2^{\circ}$ Facultativamente, poderá ser instruído também com outras peças que o agravante entender úteis.

Art. 300. No prazo do recurso, a petição de agravo, que não dependerá do pagamento de custas e despesas postais, será dirigida à Presidência do Tribunal, mediante protocolo neste, ou postada no correio sob registro de aviso de recebimento ou, ainda, interposta por outra forma prevista em lei.

Parágrafo único. O agravado será intimado, de imediato, para, no prazo de dez dias, oferecer resposta, podendo instruí-la com cópia das peças que entender convenientes. Em seguida, subirá o agravo ao tribunal superior."
} 
Há forte corrente doutrinária ${ }^{323}$, amparada por entendimento mais recente do Superior Tribunal de Justiça ${ }^{324}$, que aponta ser o agravo de instrumento o recurso cabível contra a decisão denegatória de seguimento de recurso ordinário constitucional ${ }^{325}$.

O último posicionamento adotado pela doutrina é pelo cabimento do agravo previsto no artigo 544 do Código de Processo Civil. Os fundamentos jurídicos para este entendimento são o fato de o recurso ordinário constitucional, assim como o recurso extraordinário e o recurso especial, ser dirigido a tribunal superior ${ }^{326}$; e ser o Presidente ou o Vice-Presidente do tribunal a quo - para quem tem esta percepção - o competente para realizar o primeiro exame de admissibilidade do recurso ${ }^{327}$.

Discorda-se desta corrente, pois as semelhanças entre o recurso ordinário constitucional e a apelação são muito maiores do que as entre o primeiro e os recursos extraordinários em sentido amplo.

O artigo 540 do Código de Processo Civil determina que o procedimento no juízo recorrido deve ser o mesmo na apelação e no recurso ordinário constitucional. Isso significa que o recurso cabível contra a decisão que não admite o recurso ordinário constitucional deve ser o mesmo a ser interposto contra a decisão que nega seguimento à apelação, ou seja, o agravo de instrumento, por expressa previsão do artigo 522 do Código de Processo Civil ${ }^{328}$.

\footnotetext{
323 “(...) O artigo 540 do mesmo Código, entretanto, determina a aplicação das regras dos Capítulos II e III do Título X ao recurso ordinário. O Capítulo II trata da apelação. Indo ao Capítulo III, verifica-se que cabe agravo de instrumento contra a decisão de inadmissão de apelação. Sem dúvida, a combinação dos artigos 518, 522 e 540 revela a incidência dos dispositivos da apelação quanto aos pressupostos de admissibilidade e ao procedimento do recurso ordinário na origem. Aliás, mesmo antes do advento da Lei n. 8.950, que conferiu a atual redação ao artigo 540 do Código, o artigo 34 da Lei n. 8.038 já estabelecia que ao recurso ordinário são 'aplicados, quanto aos requisitos de admissibilidade e o procedimento no Tribunal recorrido, as regras do Código de Processo Civil relativas à apelação'. Por tudo, é possível concluir que a decisão de inadmissão de recurso ordinário na justiça ou tribunal de origem é igualmente impugnável por meio de agravo de instrumento previsto no artigo 522, última parte, do Código de Processo Civil.” (SOUZA, 2007, p. 54).

Também nesse sentido: ASSIS, 2008, p. 101; e FUX, 2008, p. 935.

${ }^{324}$ Conforme citado anteriormente (nota 318 ).

${ }^{325}$ Essa era a disposição do artigo 587 do Anteprojeto do Código de Processo Civil vigente.

${ }^{326}$ ROENICK, 1999, pp. 162/163.

${ }^{327}$ AMENDOEIRA JR., 2012, p. 210; e ASSIS, 2008, p. 248.

${ }^{328}$ Nesse sentido, decisão do Superior Tribunal de Justiça, quando do julgamento do AG 377.099, em 14/06/2002, da relatoria do Min. SÁlVIO DE FIGUEIREDO TEIXEIRA:

"Resta demonstrar a inadequação do agravo de instrumento de que cuida o artigo 544 do Código de Processo Civil. O artigo 540 do mesmo diploma determina a aplicação das regras dos Capitulos II e III do Título X ao recurso ordinário. Indo ao Capítulo III, verifica-se que cabe agravo de instrumento contra a decisão que não recebe a apelação. Por tal razão, é possivel concluir que a decisão que não admite o recurso ordinário é impugnável por meio do agravo de instrumento previsto nos artigos 522, 523, § 4..$^{\circ}$, última parte, e 524' (Introdução aos Recursos Cíveis e À Ação Rescisória, Maza Editores, n. 15.2, p. 370/371).

$O$ recurso adequado à hipótese vertente é, portanto, o agravo de instrumento regulado pelos artigos 522 e seguintes do Código de Processo Civil, por analogia ao recurso cabivel contra decisão que não recebe a apelação."
} 
De qualquer forma, o importante é a aplicação do princípio da fungibilidade recursal $^{329}$. Há clara dúvida objetiva sobre qual o recurso cabível contra a decisão do juízo $a$ quo que nega seguimento a recurso ordinário constitucional e qualquer entendimento em sentido contrário, como o da Corte Especial do Superior Tribunal de Justiça, citado por THEOTONIO NEGRÃO ET $A L^{330}$, viola esse princípio.

Não se pode limitar o acesso ao juízo ad quem competente para julgar o recurso ordinário constitucional pelo eventual "equívoco"331 do recorrente, se o Superior Tribunal de Justiça tem julgados recentes que apontam três possíveis recursos cabíveis, bem como há divergência doutrinária neste ponto.

Por fim, quando o recurso ordinário constitucional é interposto de forma retida contra decisão interlocutória proferida em causa internacional, ele, sem dúvida, é dirigido ao juiz que preside a causa internacional em curso perante a Justiça Federal.

\subsection{Procedimento perante o juízo ad quem}

Segundo disposição do artigo 540, parte final, do Código de Processo Civil, o procedimento do recurso ordinário constitucional perante o juízo ad quem deve ser regulado pelos regimentos internos do Supremo Tribunal Federal e do Superior Tribunal de Justiça. A Lei $\mathrm{n}^{\circ} 8.038 / 1990$ também trata do procedimento dos recursos perante esses tribunais superiores, o que é válido para o recurso ordinário constitucional.

Não há controvérsia jurisprudencial ou doutrinária em relação ao procedimento no juízo ad quem, sendo relevante a enumeração de apenas alguns aspectos relevantes e em que o processamento desse recurso diverge do processamento da apelação.

A primeira é a inexistência de magistrado revisor no recurso ordinário constitucional $^{332}$. Segundo se extrai do artigo 40 da Lei $n^{\circ} 8.038 / 1990^{333}$, em conformidade com os artigos 35 e 248, parágrafo único, do Regimento Interno do Superior Tribunal de Justiça ${ }^{334}$, o recurso ordinário constitucional processado nessa corte não é remetido à revisão,

\footnotetext{
${ }^{329}$ SOUZA, 2011, p. 623.

${ }^{330}$ Vide nota 318.

${ }^{331}$ Aqui entre aspas porque não se considera verdadeiro equívoco do recorrente quando as posições doutrinárias e jurisprudenciais acerca do recurso cabível contra a decisão que nega seguimento a recurso ordinário constitucional são tão divergentes.

332 SOUZA, 2007, p. 49.

333 “Art. 40 - Haverá revisão, no Superior Tribunal de Justiça, nos seguintes processos:

I - ação rescisória;

II - ação penal originária;

III - revisão criminal."

334 “Art. 35. Sujeitam-se a revisão os seguintes processos:
} 
o que também se dá com o recurso de competência do Supremo Tribunal Federal, nos termos do artigo 23 do seu Regimento Interno ${ }^{335}$. A mesma conclusão é extraída da leitura do artigo 551 do Código de Processo Civil, que não enumera o recurso ordinário constitucional como um dos recursos sujeitos à revisão.

O segundo ponto que merece destaque é o quórum para a votação do recurso ${ }^{336}$. Enquanto são três magistrados que julgam os recursos de apelação e de agravo, nos termos do artigo 555, caput, do Código de Processo Civil, no recurso ordinário constitucional a votação é por todo o órgão fracionário, que é composto por, no mínimo, cinco magistrados ${ }^{337}$, tanto no Supremo Tribunal Federal (artigo $4^{\circ}$, caput, do seu Regimento Interno), quanto no Superior Tribunal de Justiça (artigo $2^{\circ}, \S 4^{\circ}$, do respectivo Regimento Interno, neste caso, combinado com o artigo 41-A da Lei $\mathrm{n}^{\circ} 8.038 / 1990^{338}$ ).

Quando interpostos recurso ordinário constitucional e recurso extraordinário, eles serão julgados em conjunto pelo Pleno do Supremo Tribunal Federal, conforme entendimento sumulado por aquela Corte $^{339}$.

No mais, o processamento do recurso ordinário constitucional perante o juízo ad quem é igual ao da apelação ou do agravo, dependendo da decisão atacada por esse tipo de recurso.

I - ação rescisória;

II - ação penal originária;

III - revisão criminal.

(...)

Art. 248. Distribuído o recurso, a Secretaria fará os autos com vista ao

Ministério Público pelo prazo de cinco dias.

Parágrafo único. Conclusos os autos ao relator, este pedirá dia para

julgamento."

335 “Art. 23. Há revisão nos seguintes processos:

I - ação rescisória;

II - revisão criminal;

III - ação penal originária prevista no art. $5^{\circ}$, I e II;

IV - recurso ordinário criminal previsto no art. $6^{\circ}$, III, $c$;

$\mathrm{V}$ - declaração de suspensão de direitos do art. $5^{\circ}$, VI.

Parágrafo único. Nos embargos relativos aos processos referidos não haverá revisão."

336 SOUZA, 2007, pp. 50/51.

${ }^{337}$ Quando o órgão fracionário que tiver competência para julgar o recurso ordinário constitucional for turma, como ocorre com os recursos dirigidos ao Superior Tribunal de Justiça (artigo 13, II e III do Regimento Interno). Importante anotar que o inciso III, que trata dos recursos interpostos em causas internacionais, ainda usa as expressões "apelação" e "agravo", não recurso ordinário constitucional.

338 “Art. 41-A - A decisão de Turma, no Superior Tribunal de Justiça, será tomada pelo voto da maioria absoluta de seus membros."

339 Súmula $\mathrm{n}^{\circ}$ 299: "O recurso ordinário e o extraordinário interpostos no mesmo processo de mandado de segurança, ou de 'habeas corpus', serão julgados conjuntamente pelo tribunal pleno”. 


\section{$\underline{6.6 \quad \text { Interposição de forma adesiva }}$}

Não se cogita do cabimento de recurso ordinário adesivo nas ações constitucionais porque, como visto anteriormente, este só é cabível contra decisão denegatória, não havendo um recurso principal de mesma natureza, portanto ${ }^{340}$. Há precedentes do Superior Tribunal de Justiça, por outro lado, que seguem essa posição ${ }^{341}$ e outros que dela divergem, conhecendo recurso especial adesivo a recurso ordinário constitucional ${ }^{342}$.

Além disso, não seria possível a aplicação do disposto no parágrafo único do artigo 500 do Código de Processo Civil, que estabelece que se aplicam, ao recurso adesivo, as mesmas regras referentes às condições de admissibilidade, preparo e julgamento no tribunal superior incidente ao recurso principal ${ }^{343}$.

Por isso, não se cogita da interposição de recurso ordinário constitucional adesivo a recurso especial ou a recurso extraordinário.

Da mesma forma, não é possível que seja interposto recurso extraordinário ou recurso especial aderindo ao recurso ordinário constitucional ${ }^{344}$. Valem, aqui, as mesmas razões pelas quais não se considera cabível o recurso ordinário constitucional adesivo: não há recurso principal da mesma espécie ao qual se possa aderir, bem como, por vezes, o tribunal ao qual é dirigido o recurso principal - extraordinário ou especial - não é o mesmo que teria competência para julgar o recurso ordinário constitucional ${ }^{345}$.

\footnotetext{
340 "Diferente, entretanto, é a admissibilidade do recurso ordinário adesivo contra arestos oriundos dos tribunais. Neste caso, a natureza da demanda está a impedir a adesividade. Perante esses, processam-se ações que adotam procedimento próprio e recorribilidade ordinária em um só sentido. Assim, além de caber o recurso exclusivamente se a ação for julgada improcedente, tratam tais causas de habeas corpus, mandado de segurança, habeas data e mandado de injunção julgados originariamente nos tribunais superiores. Da mesma forma também com recurso ordinário manejável apenas pelo impetrante -, o habeas corpus e o mandado de segurança movidos perante tribunal regional federal ou tribunal estadual. Tendo rito próprio, insista-se - e cabimento recursal ordinário em benefício exclusivo do autor -, torna-se incabível a forma adesiva do recurso nas causas ali originadas." (AMORIM, 2005, p. 207).

${ }^{341}$ STJ, RMS no 10.962/PR, Rel. Min. Humberto Gomes de Barros, $1^{\text {a }}$ Turma, j. 20/09/2001; STJ, RMS n ${ }^{\circ}$ 10.256/RO, Rel. Min. Fontes de Alencar, $6^{\mathrm{a}}$ Turma, j. 20/03/2001; e STJ, RMS no 5.085/SP, Rel. Min. Barros Monteiro, $4^{\text {a }}$ Turma, j. 19/09/1995.

${ }^{342}$ STJ, RMS n ${ }^{\circ}$ 12.227/SC, Rel. Min. Jorge Scartezzini, 5 Turma, j. 19/08/2003; STJ, RMS n ${ }^{\text {a }}$ 12.281/SC, Rel. Min. Franciulli Netto, $2^{\mathrm{a}}$ Turma, j. 08/04/2003 e STJ, RMS n 12.128/SC, Rel. Min. José Delgado, $1^{\mathrm{a}}$ Turma, j. 06/06/2002.

343 SOUZA, 2007, p. 49.

${ }^{344}$ Pode-citar o seguinte precedente jurisprudencial nesse sentido: STJ, RMS no 18.515/SE, Rel. Min. Laurita

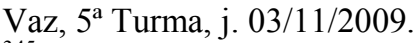

${ }^{345}$ Por exemplo: é denegada em parte a segurança em mandado de segurança de competência originária de tribunal estadual, com fundamento no respeito à Constituição Federal. Neste caso, é possível a interposição de recurso ordinário constitucional contra a parte denegatória do acórdão, que é de competência do Superior Tribunal de Justiça; bem como é possível a interposição de recurso extraordinário contra a parte concessiva do acórdão, recurso este que deve ser julgado pelo Supremo Tribunal Federal. É impossível que a autoridade coatora adira ao recurso ordinário constitucional interposto pelo impetrante, e vice-versa, porque a competência para julgamento do recurso ordinário constitucional e do recurso extraordinário, na espécie, é diversa.
} 
Nas causas internacionais, em que não é exigido o requisito de ser denegatória a decisão atacada por meio do recurso ordinário constitucional, a interposição desse pela via adesiva não encontra impedimento lógico, havendo autores que defendem o seu cabimento e outros contrários a ele.

A primeira corrente entende que, dada a semelhança entre a apelação e o recurso ordinário constitucional nas causas internacionais e a disposição do artigo 540 do Código de Processo Civil, que determina a aplicação dos mesmos requisitos de admissibilidade a essas espécies recursais, seria possível a interposição de recurso ordinário constitucional adesivo ${ }^{346}$.

A omissão do artigo 500, II, do Código de Processo Civil não seria relevante, sendo plenamente possível a interpretação analógica do cabimento dessa forma de interposição do recurso $^{347}$.

Por outro lado, a justificativa da posição contrária, pela impossibilidade de interposição de recurso ordinário adesivo, é exatamente essa omissão legislativa ${ }^{348}$. O referido artigo 500, II, do Código de Processo Civil teve sua redação modificada em 1994, sem que fosse incluído entre as espécies recursais passíveis de interposição adesiva o recurso ordinário constitucional. Isso representaria um "silêncio eloquente", o que impediria a interpretação da norma por analogia ${ }^{349}$.

Concorda-se com a segunda corrente doutrinária. O fato da norma processual, mesmo depois de reformada, não ter incluído o recurso ordinário constitucional entre aqueles que podem ser apresentados de forma adesiva revela o desejo do legislador de impedir essa modalidade de interposição. Não se pode aplicar a analogia nesse caso, pois seria contrária ao espírito da lei.

Aí uma diferença procedimental entre o recurso ordinário constitucional é a apelação, o que é prova da autonomia do primeiro em relação às demais espécies recursais.

\subsection{Cabimento de embargos infringentes}

A doutrina nacional apresenta posições variadas sobre a possibilidade de oposição de embargos infringentes contra acórdão não unânime que julgue recurso ordinário constitucional, reformando a decisão recorrida.

\footnotetext{
${ }^{346}$ AMENDOEIRA JR., 2012, p. 218; AMORIM, 2005, p. 206/209; e DIDIER JR. e CUNHA, 2010, p. 251; e NERY JR. e NERY, 2012, p. 1.096.

${ }^{347}$ DINAMARCO, 1995, p. 193.

${ }^{348}$ ASSIS, 2008, pp. 75 e 92; e SOUZA, 2007, pp. 48 e 82.

${ }^{349}$ ROENICK, 1999, p. 160.
} 
O posicionamento mais permissivo entende ser possível a oposição de embargos infringentes em qualquer tipo de recurso ordinário constitucional, desde que atendidas as hipóteses de cabimento específicas dos embargos infringentes ${ }^{350}$. Essa interpretação tem por base a integração das normas de processamento do recurso de apelação com as referentes ao recurso ordinário constitucional, prevista no artigo 540 do Código de Processo Civil.

Uma corrente mais moderada afirma que os embargos infringentes poderiam ser opostos apenas contra acórdão que julga recurso ordinário constitucional em causa internacional $^{351}$. Entende-se que, em caso de ações constitucionais - em especial mandado de segurança -, a oposição dos embargos não seria permitida em razão da natureza da causa. Todavia, pela grande semelhança entre a apelação e o recurso ordinário constitucional nas causas internacionais, seria possível a oposição de embargos infringentes contra acórdão não unânime que houvesse reformado a decisão recorrida.

Já a posição doutrinária mais restritiva entende que os embargos infringentes não poderiam ser opostos em sede de recurso ordinário constitucional, qualquer que fosse a ação em que foi interposto este recurso ${ }^{352}$. Interpreta-se restritiva e literalmente o artigo 530 do Código de Processo Civil, sendo cabíveis os embargos infringentes apenas em sede de apelação ou de ação rescisória, ainda que nada impedisse a sua oposição em recurso ordinário constitucional, pela natureza deste.

A jurisprudência dos tribunais superiores, por outro lado, é pacífica no sentido de não ser possível a oposição de embargos infringentes em sede de recurso ordinário constitucional. Tanto o Supremo Tribunal Federal ${ }^{353}$ quanto o Superior Tribunal de Justiça sumularam esse entendimento $^{354}$, que também acabou sendo positivado pelo artigo 25 da Lei no 12.016/2009.

De fato não parece ser cabível a oposição de embargos infringentes em sede de recurso ordinário constitucional, seja nas ações constitucionais, seja nas causas internacionais.

O artigo 530 do Código de Processo Civil foi objeto de reforma em 2001, tendo sido restringidas as hipóteses de cabimento dos embargos infringentes ${ }^{355}$. Assim, seria contrária ao

\footnotetext{
${ }^{350}$ FUX, 2008; p. 937; GONÇALVES, M., 2012b, p. 148; e NEGRÃO ET AL, 2012, p. 720.

${ }^{351}$ ASSIS, 2011, pp. 654 e 671; e DIDIER JR. e CUNHA, 2010, pp. 247 e 251.

${ }^{352}$ AMENDOEIRA JR., 2012, p. 211; e GOMES JÚNIOR, 2003, p. 490.

${ }^{353}$ Súmula $n^{\circ}$ 597: "Não cabem embargos infringentes de acórdão que, em mandado de segurança, decidiu por maioria de votos a apelação."

${ }^{354}$ Súmula no 169: "São inadmissíveis embargos infringentes no processo de mandado de segurança."

355 “O propósito do legislador ao reformar o art. 530, foi, sem dúvida, o de restringir o cabimento dos embargos infringentes ao terreno do mérito da causa, se sorte que embargável, atualmente, só é o acórdão que solucione questão de mérito, e nunca o que se limite a apreciar a matéria de preliminar, como as pertinentes aos pressupostos processuais e às condições da ação (cf. Cândido Rangel Dinamarco, A reforma da reforma, São Paulo, Malheiros, 2002, p. 202; Pedro Miranda de Oliveira, 'O novo regime dos embargos infringentes'. In: Nelson Nery Júnior e Teresa Arruda Alvim Wambier (coord.). Aspectos polêmicos e atuais dos recursos cíveis,
} 
espírito da lei a interpretação mais abrangente do cabimento desse recurso, ainda que não haja nenhum óbice teórico ou prático para tanto, como se dá com o recurso ordinário constitucional, em especial nas causas internacionais.

Essa é outra peculiaridade procedimental do recurso ordinário constitucional que demonstra ser esse recurso autônomo e diverso dos demais recursos ordinários em sentido amplo, em especial da apelação.

\subsection{Cabimento de embargos de divergência}

O último aspecto procedimental referente ao recurso ordinário constitucional que será abordado nesta dissertação é o cabimento ou não de embargos de divergência contra acórdão que julgue o recurso ordinário constitucional.

O recurso de embargos de divergência está previsto nos artigos 496, VIII, e 546 do Código de Processo Civil, bem como nos artigos 330 a 336 do Regimento Interno do Supremo Tribunal Federal e nos artigos 266 e 267 do Regimento Interno do Superior Tribunal de Justiça. A sua finalidade é harmonizar a interpretação da norma dentro dos próprios tribunais superiores, acabando com divergências internas ${ }^{356}$ e, assim, garantir a isonomia para o jurisdicionado ${ }^{357}$.

A origem remota dos embargos de divergência é a divisão do Supremo Tribunal Federal em turmas ${ }^{358}$, o que passou a permitir, em tese, que esses órgãos fracionários interpretassem a mesma norma constitucional de maneiras diversas, o que traz insegurança jurídica. A divergência interna, no âmbito dos tribunais superiores, que têm a função precípua de pacificar a interpretação da lei ${ }^{359}$, é bastante perigosa, porque gera dúvida em relação a qual a correta interpretação, bem como trata duas situações idênticas de forma distinta, o que viola a garantia constitucional da igualdade ${ }^{360}$.

São Paulo, RT, 2003, v. 7, p. 617; Carlos Alberto Carmona, 'O sistema recursal brasileiro: breve análise crítica'. In: Eduardo Pellegrini de Arruda Alvim et al. (coord.). Aspectos polemicos e atuais dos recursos, São Paulo, RT, 2000, p. 40.” (THEODORO JÚNIOR, 2009a, p. 619).

356 ARAKEN DE ASSIS (2011, pp. 847/848), BERNARDO PIMENTEl SOUZA (2011, p. 544), HELENA NAJJAR ABDO (2006, p. 248), Rodrigo dA CUNHA LiMA Freire (2008, pp. 1.211/1.212) e SÉRgio SEIJI SHIMURA (1998, p. 416) defendem essa posição. FLÁVIO CHEIM JORGE (2010, p. 16) também considera que a harmonização da jurisprudência seja consequência dos embargos de divergência, mas entende que a sua finalidade é "evidenciar a real interpretação do Tribunal a respeito de uma determinada questão jurídica”.

357 ABDO, 2006, p. 229.

${ }^{358}$ CHEIM JORGE, 2010, pp. 10/11.

${ }^{359}$ Conforme se verá no capítulo 7 desta dissertação.

${ }^{360}$ LASPRO, 2010, pp. 10/11. 
Os embargos de divergência já foram cabíveis em qualquer processo de competência do Supremo Tribunal Federal, à época em que não existia o Superior Tribunal de Justiça, porém a partir de 1967 suas hipóteses de cabimento foram restritas às atuais ${ }^{361}$.

Os embargos de divergência, restritos ao Supremo Tribunal Federal e ao Superior Tribunal de Justiça ${ }^{362}$, servem como mecanismo complementar ao incidente de uniformização de jurisprudência e têm vantagens em relação a esse, pois são opostos pela parte, após a instauração da divergência jurisprudencial, com fins de remediá-la, não preveni-la, como faz o incidente de uniformização de jurisprudência ${ }^{363}$.

Não é o objetivo deste trabalho conceituar a fundo os embargos de divergência, mas sim verificar se eles são ou não cabíveis contra acórdão que julga recurso ordinário constitucional.

Apenas pequena parcela da doutrina defende o cabimento de embargos de divergência em sede de recurso ordinário constitucional.

Oreste Nestor de Souza Laspro entende que, do ponto de vista político, os embargos de divergência deveriam ter cabimento em todos os processos julgados pelos tribunais superiores, pois a divergência interpretativa nessas cortes não seria aceitável em nenhuma hipótese ${ }^{364}$. Deveria se interpretar a lei de forma ampliativa, de modo a admitir os embargos de divergência também em relação aos recursos que exercem função similar ao recurso extraordinário e ao recurso especial ${ }^{365}$.

Especificamente em relação ao recurso ordinário constitucional, defende o cabimento de embargos de divergência porque o âmbito de cognição do recurso ordinário constitucional é muito mais amplo que o dos recursos extraordinário e especial, não sendo lógico que nestes o recurso seja cabível e naquele não - posição esta também defendida por MARCO AURÉLIO MELLO, que aponta a incongruência do sistema recursal caso seja adotada interpretação oposta $^{366}$-; bem como aponta que seria mais vantajoso ao Poder Público sucumbir no primeiro julgamento, para interpor recurso especial ou extraordinário e, assim, ter aberta a via

\footnotetext{
${ }^{361}$ HELENA NAJJAR ABDo (2006, pp. 223/229) faz excelente digressão histórica sobre o cabimento de embargos de divergência, que foram disciplinados pela primeira vez pelo Dec. 6, de 16/11/1937, quando eram cabíveis contra qualquer decisão de turma do STF que divergisse da jurisprudência de outra turma ou do Plenário, foram revogados pelo Código de Processo Civil de 1939, restaurados pela Lei no $623 / 49$, que não os disciplinou, vindo essa disciplina por meio de alteração do Regimento Interno do Supremo Tribunal Federal ocorrida em 1963 e sendo o seu âmbito restrito às hipóteses atuais apenas a partir de 1967, quando de mais uma reforma do do Regimento Interno do Supremo Tribunal Federal.

362 BUENO, 2011, pp. 347/348.

${ }^{363}$ FÉRES, 2006, pp. 714/715; LASPRO, 2010, pp. 11/12.

364 LASPRO, 2010, pp. 16/17.

365 Idem, p. 17.

${ }^{366}$ MELLO, 2009, pp. 461/462.
} 
dos embargos de divergência, do que o contrário, quando provido o recurso ordinário constitucional não serem cabíveis embargos de divergência ${ }^{367}$. Limita, todavia, a devolução dos embargos de divergência às matérias que poderiam ser arguidas se esse recurso fosse oposto em recurso extraordinário ou recurso especial, ou seja, a direito federal constitucional quando o recurso ordinário constitucional for julgado pelo Supremo Tribunal Federal e a direito federal infraconstitucional quando for julgado pelo Superior Tribunal de Justiça ${ }^{368}$.

A maior parte da doutrina, contudo, considera que os embargos de divergência não são cabíveis em sede de recurso ordinário constitucional. Os principais motivos desse entendimento são a interpretação literal dos artigos 496, VIII, e 546 do Código de Processo Civil, que expressamente limitam os embargos de divergência ao recurso extraordinário e ao recurso especial ${ }^{369}$; as finalidades diversas desses recursos, quando comparadas com o objetivo do recurso ordinário constitucional ${ }^{370}$, conforme já explicado anteriormente (Capítulo 3); e o fato do Supremo Tribunal Federal tradicionalmente não ver os embargos de divergência com bons olhos, sempre interpretando o seu cabimento de forma restritiva ${ }^{371}$.

A jurisprudência, tanto do Supremo Tribunal Federal ${ }^{372}$, quanto do Superior Tribunal de Justiça ${ }^{373}$, é pacífica no sentido de que não cabem embargos de divergência contra acórdão que julgue recurso ordinário constitucional.

Concorda-se com a segunda posição, de que os embargos de divergência não podem ser opostos em sede de recurso ordinário constitucional. A lei é muito clara quando define as hipóteses de cabimento de embargos de divergência: apenas contra acórdãos que julguem recurso extraordinário ou recurso especial. Não há margem para interpretação ampliativa nesse caso, até porque a analogia não é cabível, dado que o recurso ordinário constitucional é um recurso ordinário em sentido amplo, que serve para efetivar o duplo grau de jurisdição, enquanto os recursos extraordinário e especial são extraordinários em sentido amplo, com o objetivo de debater apenas questões de direito.

\footnotetext{
${ }^{367}$ LASPRO, 2010, pp. 20/21.

${ }^{368}$ Idem, p. 22.

369 ASSIS, 2011, pp. 851/852; BUENO, 2011, p. 350; DELGADO, 2006, p. 811; FREIRE, 2008, p. 1.216; KOZIKOSKI, 2011, pp. 426/427; SHIMURA, 1998, p. 417; e SOUZA, 2011, p. 552.

${ }^{370}$ CHEIM JORGE, 2010, p. 26.

${ }^{371}$ BOTELHO DE MESQUITA, 2005, pp. 196/197.

${ }^{372}$ STF, AgRg no AgRg no HC n 88.247, Rel. Min. Celso de Mello, Tribunal Pleno, j. 17/09/2009; STF, EDv no RHC n 94.451/GO, Rel. Min. Cármen Lúcia, Tribunal Pleno, j. 21/05/2009; e STF, ED-EDv em RMS nº 22.926/DF, Rel. Min. Gilmar Mendes, Tribunal Pleno, j. 19/02/2003.

${ }^{373}$ DANIEL WILLIAN GRANADO (2010) coordenou pesquisa de 2.271 acórdãos do Superior Tribunal de Justiça que tratavam de embargos de divergência e concluiu que a jurisprudência pacífica daquele tribunal considera que os embargos de divergência não podem ser opostos em recurso ordinário constitucional, porque os requisitos de admissibilidade desse recurso seriam muito diferentes dos requisitos de admissibilidade do recurso especial.
} 
Também não se pode concordar com a afirmação de ORESTE NESTOR DE SOUZA LASPRO no sentido de que seria mais vantajoso ao Poder Público ser vencido em primeiro julgamento, apenas para que fossem cabíveis, posteriormente, embargos de divergência. As hipóteses de cabimento e os requisitos de admissibilidade do recurso extraordinário, do recurso especial e dos próprios embargos de divergência são muito mais restritos que os do recurso ordinário constitucional, bem como o âmbito de devolução é muito menor. Assim, de forma alguma é preferível sair vencido em primeiro julgamento, só para que seja possível, eventualmente, opor embargos de divergência no futuro.

Por fim, ainda que o tema não seja voltado ao estudo do recurso ordinário constitucional, mas sim dos embargos de divergência, há controvérsia entre a maior parte da doutrina, de um lado, e a jurisprudência pacífica dos tribunais superiores, de outro, quanto à possibilidade do acórdão paradigma que embasa a oposição dos embargos de divergência poder ou não ter sido proferido quando do julgamento de recurso ordinário constitucional.

Corrente doutrinária majoritária ${ }^{374}$ considera ser possível que o acórdão paradigma seja proveniente de recurso ordinário constitucional, porque a lei não faria qualquer restrição nesse ponto. Porém, a jurisprudência consolidada do Supremo Tribunal Federal ${ }^{375}$ e do Superior Tribunal de Justiça ${ }^{376}$ entende que o paradigma também deve ter sido proferido quando julgado recurso extraordinário ou recurso especial, respectivamente.

Respeitada a orientação jurisprudencial, concorda-se com a doutrina dominante. Se a lei não faz restrição no que se refere ao acórdão paradigma, não é legítimo que a jurisprudência o faça.

\footnotetext{
${ }^{374}$ Essa corrente é formada por BERNARDo PIMENTEL SOUZA (2011, p. 557), DANIEL WILLIAN GRANADO (2010, 278), Rodrigo da CunHa Lima Freire (2008, p. 1.220) e SÉrgio SEII SHimura (1998, p. 418).

Com entendimento minoritário, no sentido de que o acórdão paradigma que possibilita a oposição de embargos de divergência dever ser proferido em recurso extraordinário ou recurso especial, cita-se ARAKEN DE ASSIS (2011, p. 855).

${ }^{375}$ STF, EDv-ED no RE no 140.829/DF, Rel. Min. Celso de Mello, Tribunal Pleno, j. 15/12/2011; e STF, AgRg no EDv no RE no 300.172/MG, Rel. Min. Cezar Peluso, Tribunal Pleno, j. 02/06/2010.

${ }^{376}$ Cita-se novamente a pesquisa coordenada por DANIEL WILLIAN GRANADO (2010, p. 278).
} 


\section{ANÁLISE CRÍTICA DO RECURSO ORDINÁRIO CONSTITUCIONAL}

Vista a evolução histórica do recurso ordinário constitucional, suas hipóteses de cabimento e seus aspectos procedimentais, além de situada a espécie recursal entre os recursos ordinários em sentido amplo, em confronto com os extraordinários em sentido amplo, resta examinar se esse recurso deve ou não ser mantido no ordenamento jurídico pátrio e, concluindo-se pela sua manutenção, se as hipóteses de cabimento devem ser reduzidas, mantidas ou aumentadas.

Para se realizar essa análise crítica não se pode perder de vista a origem e a evolução histórica do recurso ordinário constitucional, tratadas no Capítulo 4 desta dissertação.

Também é necessário estudar mais a fundo quais as funções de dois dos tribunais superiores brasileiros, o Supremo Tribunal Federal e o Superior Tribunal de Justiça, únicos competentes para julgar recurso ordinário constitucional.

Em seguida, far-se-á um breve exame das funções de tribunais superiores estrangeiros, tanto europeus quanto latino-americanos, verificando-se se essas cortes têm competência originária e/ou recursal ordinária em certos casos e quais são esses, o que apontaria semelhança com o recurso ordinário constitucional.

7.1 Funções dos tribunais superiores brasileiros - Supremo Tribunal Federal e Superior Tribunal de Justiça

O Supremo Tribunal Federal é a corte de maior hierarquia na estrutura organizacional judiciária brasileira. O seu presidente é o chefe do Poder Judiciário, sendo o quinto na linha sucessória de governo ${ }^{377}$. Por não existir no Brasil uma corte constitucional, nos moldes da corte constitucional alemã ${ }^{378}$, o Supremo Tribunal Federal é o guardião maior da Carta Magna $^{379}$, mesmo sendo órgão integrante de um dos três Poderes, o Poder Judiciário.

Essa é a principal tarefa do Supremo Tribunal Federal: zelar para que a Constituição Federal seja respeitada ${ }^{380}$. Realiza esse controle de constitucionalidade de forma concentrada, por meio das chamadas ações objetivas (ação direta de inconstitucionalidade, ação

\footnotetext{
${ }^{377}$ Artigo 80 da Constituição Federal.

${ }^{378}$ NERY JÚNIOR, 2010, pp. 44/45.

${ }^{379}$ Função prevista no artigo 102, caput, da Constituição Federal.

${ }^{380}$ DINAMARCO, 2005, p. 480; BUENO, 2012, p. 216; MORAES, 2011, p. 551; e NERY JÚNIOR e NERY, 2009 , p. 475.
} 
declaratória de constitucionalidade, arguição de descumprimento de preceito fundamental, mandado de injunção etc), e também por meio de controle difuso de constitucionalidade, este exercido principalmente por meio do recurso extraordinário ${ }^{381}$.

Além dessa função de guarda da Constituição Federal, o Pretório Excelso possui outras funções jurisdicionais, tendo competência originária para julgar: (i) o Presidente e o Vice-Presidente da República, membros do Congresso Nacional ${ }^{382}$, seus próprios integrantes e o Procurador-Geral da República por crimes comuns (artigo 102, I, b, da Constituição Federal); (ii) os Ministros de Estado e os Comandantes das Forças Armadas, os membros dos tribunais superiores e do Tribunal de Contas da União, e os chefes de missão diplomática permanente, por crimes comuns e de responsabilidade (artigo 102, I, c, da Constituição Federal); (iii) o habeas corpus em que for paciente qualquer das pessoas acima informada, o mandado de segurança e o habeas data impetrados contra ato do Presidente da República, das Mesas da Câmara dos Deputados e do Senado, do Tribunal de Contas da União, do Procurador-Geral da República e do Supremo Tribunal Federal (artigo 102, I, $d$, da Constituição Federal); (iv) o processo em que figure, de um lado, a União, Estado, o Distrito Federal ou Território, e, de outro, Estado estrangeiro ou organismo internacional (artigo 102, I, $e$, da Constituição Federal); (v) processos e conflitos que envolvem União, Estados, Distrito Federal e respectivas entidades da administração indireta, uns contra os outros (artigo 102, I, f, da Constituição Federal); (vi) extradições solicitadas por Estados estrangeiros (artigo 102, I, g, da Constituição Federal); (vii) habeas corpus contra ato de tribunal superior ou quando o paciente for "autoridade ou funcionário cujos atos estejam sujeitos diretamente à jurisdição do Supremo Tribunal Federal, ou se trate de crime sujeito à mesma jurisdição em uma única instância" (artigo 102, I, i, da Constituição Federal); (viii) revisão criminal e ação rescisória que discutam decisão do próprio Supremo Tribunal Federal (artigo 102, I, j, da Constituição Federal); (ix) reclamações ajuizadas para garantir a preservação da sua competência e a autoridade das suas decisões (artigo 102, I, l, da Constituição Federal); (x) execução de sentença das causas de sua competência (artigo 102, I, $m$, da Constituição Federal); (xi) ação em todos os membros da magistratura ou que mais da metade dos integrantes de um determinado tribunal sejam direta ou indiretamente interessados, bem como ação em que mais da metade dos integrantes de um determinado tribunal estejam impedidos (artigo 102, I, $n$, da Constituição Federal); e (xii) processos em que figurem como réu o Conselho Nacional de

\footnotetext{
${ }^{381}$ NERY JÚNIOR, 2010, pp. 46/47.

${ }^{382}$ Recentemente, a Ação Penal n ${ }^{\circ} 470$, que tratou da prática do chamado "Mensalão", ocupou a pauta do Supremo Tribunal Federal por quase 06 (seis) meses, travando o julgamento de diversos processos, entre eles recursos extraordinários em que já se havia reconhecido repercussão geral.
} 
Justiça ou o Conselho Nacional do Ministério Público (artigo 102, I, r, da Constituição Federal).

Também possui competência recursal ordinária para julgar recurso ordinário constitucional interposto (i) contra decisão denegatória de mandado de segurança, mandado de injunção, habeas corpus e habeas data, decididos em única instância por tribunal superior (artigo 102, II, $a$, da Constituição Federal); e (ii) em processos que apurem a prática de crime político (artigo 102, II, $b$, da Constituição Federal).

Essas outras atribuições são um dos motivos pelos quais o Supremo Tribunal Federal não pode ser considerado uma corte constitucional de modelo clássico ${ }^{383}$.

O Superior Tribunal de Justiça foi criado pela Constituição Federal de 1988 como tribunal superior federal, que teria como missão precípua zelar pela inteireza da legislação federal infraconstitucional ${ }^{384}$. Essa atribuição era do Supremo Tribunal Federal, mas em razão da crise pela qual aquele tribunal passava, com um excessivo número de processos a serem examinados pelos seus Ministros integrantes, entendeu-se por bem criar outro tribunal de nível federal, com competência infraconstitucional, para "desafogar" o Supremo Tribunal Federal $^{385}$.

O controle do respeito ao direito federal infraconstitucional é feito sobretudo por meio do recurso especial, espécie recursal que se enquadra entre as extraordinárias em sentido amplo, conforme exposto no Capítulo 3 desta dissertação.

Mas, além dessa competência recursal, o Superior Tribunal de Justiça julga originariamente os seguintes casos: (i) Governadores, por crimes comuns, e Desembargadores, membros dos Tribunais de Contas dos Estados, do Distrito Federal e dos Municípios, dos Tribunais Regionais Federais, dos Tribunais Regionais Eleitorais, dos Tribunais Regionais do Trabalho e do Ministério Público da União que oficiem perante tribunais, por crimes comuns e de responsabilidade (artigo 105, I, $a$, da Constituição Federal); (ii) mandado de segurança e habeas data impetrado contra ato de Ministro de Estado, de Comandante das Forças Armadas ou do próprio Superior Tribunal de Justiça (artigo 105, I, $b$, da Constituição Federal); (iii) habeas corpus quando o coator ou o paciente for qualquer das pessoas mencionadas na alínea $a$ do artigo 105, I, da Constituição Federal, ou quando o coator for tribunal sujeito à sua jurisdição ou Comandante das Forças Armadas, ressalvada a competência da Justiça Eleitoral (artigo 105, I, c, da Constituição Federal); (iv) conflito de

\footnotetext{
${ }^{383}$ NERY JÚNIOR, 2010, pp. 44/45.

${ }^{384}$ DINAMARCO, 2005, p. 480; e MORAES, 2011, p. 563.

${ }^{385}$ MANCUSO, 2013, pp. 69/74 e 100/101.
} 
competência entre tribunais ordinários, entre tribunal e juiz a ele não vinculado e entre juízes vinculados a diferentes tribunais (artigo 105, I, $d$, da Constituição Federal); (v) revisões criminais e ações rescisórias de seus julgados (artigo 105, I, e, da Constituição Federal); (vi) reclamações ajuizadas para garantir a preservação da sua competência e a autoridade das suas decisões (artigo 105, I, $f$, da Constituição Federal); (vii) conflitos de atribuição entre autoridades administrativas e judiciárias da União, ou entre essas autoridades de um Estado e outro e/ou do Distrito Federal e/ou da União (artigo 105, I, g, da Constituição Federal); (viii) mandado de injunção, quando a competência para elaborar a norma regulamentadora for de órgão, autoridade ou entidade federal, com exceções (artigo 105, I, $h$, da Constituição Federal); e (ix) homologação de sentença estrangeira e concessão de eficácia a cargas rogatórias (artigo 105, I, i, da Constituição Federal).

O Superior Tribunal de Justiça tem competência para julgar, em sede de recurso ordinário constitucional: (i) habeas corpus apreciados em única ou última instância por Tribunais Regionais Federais, Tribunais de Justiça Estaduais ou Distritais, se denegatória a decisão (artigo 105, II, $a$, da Constituição Federal); (ii) mandados de segurança decididos em única instância pelos mesmos tribunais acima citados, também se denegatória a decisão (artigo 105, II, $b$, da Constituição Federal); e (iii) causas internacionais, que são aquelas em que litiga Estado estrangeiro ou organismo internacional, de um lado, e Município ou pessoa domiciliada no Brasil, de outro (artigo 105, II, c, da Constituição Federal).

Por serem os guardas das normas federais, constitucionais e infraconstitucionais, o Supremo Tribunal Federal e o Superior Tribunal de Justiça são responsáveis pela harmonização da interpretação jurisprudencial dessas normas em todo o Brasil ${ }^{386}$.

Aplicam direito federal 05 (cinco) Tribunais Regionais Federais, 26 (vinte e seis) Tribunais de Justiça Estaduais e 01 (um) Tribunal de Justiça do Distrito Federal e dos Territórios, sendo natural que haja divergências nessa aplicação. Daí a necessidade de tribunais superiores, que, ao concentrarem o exame do direito federal aplicado em todo território nacional, funcionam como um funil, apontando qual a correta interpretação de determinada norma ${ }^{387}$.

Por meio dessa pacificação jurisprudencial criam-se precedentes, que cada vez mais influenciam o julgamento de causas ${ }^{388}$. Esses precedentes também podem ter caráter vinculante, como, por exemplo, é o caso das Súmulas Vinculantes editadas pelo Supremo

\footnotetext{
${ }^{386}$ FONSECA, 2012, pp. 25/26.

${ }^{387}$ DINAMARCO, 2005, pp. 486/487; e FONSECA, 2012, p. 43

${ }^{388}$ FONSECA, 2012, pp. 44/45.
} 
Tribunal Federal, ou do julgamento dos casos que têm repercussão geral, requisito de admissibilidade de recurso extraordinário pelo Pretório Excelso.

A doutrina ${ }^{389}$ aponta que a competência do Supremo Tribunal Federal - e também do Superior Tribunal de Justiça - é determinada com base em três critérios: harmonia entre poderes, regime federativo e convivência internacional com outros Estados ${ }^{390}$.

Nos casos de competência recursal ordinária, mas principalmente nos de competência originária, os critérios predominantes são a harmonia entre poderes e a convivência internacional. $\mathrm{O}$ critério de tentativa de harmonização entre os poderes se evidencia, a título exemplificativo, nos casos previstos no artigo 102, I, alíneas $b, c, d, f, i$ e $r$, e no artigo 105, I, alíneas $a, b, g$ e $h$, ambos da Constituição Federal. Já o critério de convivência internacional se mostra presentes nas hipóteses enumeradas no artigo 102, I, alíneas e e g, e no artigo 105, I, $i$, e II, $c$, também da Carta Magna.

Ademais, os tribunais superiores, seja no Brasil, seja no mundo, mas com especial destaque para a América Latina, são os principais responsáveis pelo respeito aos direitos fundamentais e liberdades pessoais ${ }^{391}$. Após anos de ditaduras militares em diversos países latino-americanos, entre eles o Brasil, muniu-se as cortes superiores de poderes amplos a fim de resguardar o cidadão da ingerência estatal que possa ferir ou ameaçar suas liberdades individuais e seus direitos fundamentais. O amparo, criado no México e difundido para boa parte dos países de língua espanhola, é uma das principais ferramentas de efetivação dessa proteção $^{392}$.

Em suma, os tribunais superiores brasileiros têm as seguintes funções (i) serem os guardas das normas federais, constitucionais, no caso do Supremo Tribunal Federal, e infraconstitucionais, no caso do Superior Tribunal de Justiça, o que pode ser feito por meio da pacificação da interpretação jurisprudencial dessas normas e da criação de precedentes, vinculantes ou não; (ii) assegurarem a harmonia entre os Poderes; e (iii) zelarem pelo respeito aos direitos fundamentais e às liberdades individuais.

Entre elas, destacam-se a primeira e a última. A guarda da legislação federal por um órgão de sobreposição é essencial para um estado federativo ${ }^{393}$, pois mantém a unidade da federação e efetiva a igualdade entre os seus habitantes. A proteção dos direitos fundamentais

\footnotetext{
${ }^{389}$ DINAMARCO, 2005, pp. 478/479.

${ }^{390}$ Este último critério, de convivência harmônica com outros Estados estrangeiros é bastante questionável, não se mostrando presente na definição da competência de nenhum tribunal superior europeu examinado nesta dissertação.

391 DINAMARCO, 2010, p. 194.

392 Idem, p. 196.

${ }^{393}$ BUENO, 2011, pp. 270/271.
} 
e das liberdades públicas do cidadão também não pode deixar de ser feito pelos tribunais superiores, que são menos influenciáveis por pressões políticas locais que possam ameaçar esses direitos.

A crítica às demais atribuições e o reforço a essa conclusão serão mais bem explorados no item 7.3 desta dissertação, a seguir.

\subsection{Direito estrangeiro}

É importante verificar se algum ordenamento jurídico estrangeiro prevê competência recursal ordinária para os seus tribunais de sobreposição, para identificar eventual recurso similar ao recurso ordinário constitucional em legislação de outro país. Da mesma forma, examinar se esses tribunais superiores exercem competência originária contribui para definir quais as funções desses órgãos julgadores no mundo.

Escolheu-se examinar os ordenamentos jurídicos apenas de países de civil law, assim como o Brasil, por adotarem a mesma estrutura jurídica, sendo a comparação nesses casos mais simples e direta.

Entre os países de civil law, optou-se por estudar tanto ordenamentos jurídicos europeus, que contribuíram de forma relevante para a formação do sistema recursal brasileiro, quanto latino-americanos, notadamente de países com história política similar à brasileira que passaram por ditadura militar e desde os anos 1980 estão em processo de democratização e abertura econômica internacional.

Assim, serão analisadas as legislações europeias da Itália, da França, de Portugal e da Espanha, e as legislações latino-americanas da Argentina e do Uruguai.

A Itália organiza-se com dois tribunais de sobreposição: a Corte Costituzionale, tribunal que não faz parte do Poder Judiciário e é uma típica corte constitucional clássica ${ }^{394}$, e a Corte Suprema di Cassazione, este sim órgão máximo do Poder Judiciário, ambos com jurisdição em todo território italiano ${ }^{395}$.

\footnotetext{
${ }^{394}$ Assim a previsão do artigo 134 da Costituzione della Repubblica Italiana:

"Art. 134.

La Corte costituzionale giudica:

sulle controversie relative alla legittimità costituzionale delle leggi e degli atti, aventi forza di legge, dello Stato e delle Regioni;

sui conflitti di attribuzione tra i poteri dello Stato e su quelli tra lo Stato e le Regioni, e tra le Regioni; sulle accuse promosse contro il Presidente della Repubblica, a norma della Costituzione."

${ }^{395} \mathrm{O}$ artigo 65 do Regio decreto 30 gennaio 1941, n. 12, norma jurídica que trata da competência da Corte Suprema di Cassazione assim dispõe:

"Art. 65.

Attribuzioni della corte suprema di cassazione
} 
A única competência originária desses tribunais que exige a apreciação de fatos ${ }^{396}$, mas de forma bastante restrita, sem necessidade de dilação probatória, é a de julgamento de conflitos de competência e de atribuição - conflitos de atribuição entre os poderes do Estado e entre o Estado unitário italiano e as regiões italianas, no caso da Corte Costituzionale, e conflitos de competência e de atribuição entre os diferentes tribunais italianos, no caso da Corte Suprema di Cassazione.

$\mathrm{O}$ recurso de appello, extremamente similar à nossa apelação, é de competência apenas dos tribunais ordinários ${ }^{397}$, não podendo ser levado a exame dos tribunais superiores italianos.

Dessa forma, as cortes italianas de sobreposição não possuem competência originária ou recursal ordinária nos moldes do Supremo Tribunal Federal e do Superior Tribunal de Justiça, o que mostra que não se pode comparar o recurso ordinário constitucional a nenhum recurso previsto no ordenamento jurídico italiano.

A França se organiza de forma similar à Itália: há um órgão que tem a função de zelar pela integridade da Constituição, mas com uma estrutura bastante diferente de uma corte constitucional clássica, que é o Conseil Constitutionnel; e outro que está no ápice da estrutura judiciária, a Cour de Cassation.

O Conseil Constitutionnel é órgão que realiza controle prévio de constitucionalidade das leis elaboradas pelo Parlamento francês ${ }^{398}$, bem como é órgão competente para apreciar a

La corte suprema di cassazione, quale organo supremo della giustizia, assicura l'esatta osservanza e l'uniforme interpretazione della legge, l'unità del diritto oggettivo nazionale, il rispetto dei limiti delle diverse giurisdizioni; regola i conflitti di competenza e di attribuzioni, ed adempie gli altri compiti ad essa conferiti dalla legge.

La corte suprema di cassazione ha sede in Roma ed ha giurisdizione su tutto il territorio del regno, dell'impero e su ogni altro territorio soggetto alla sovranità dello Stato.”

396 Já que o recurso que é julgado por excelência julgado pela Corte Suprema di Cassazione, o de cassação, não aprecia fatos (FAZZALARI, 1960, pp. 199/200), tendo função apenas nomofilática (MAZZARELLA, 1994, pp. $15 / 18)$.

${ }^{397}$ Nesse sentido, o artigo 341 do Codice di Procedura Civile:

"Art. 341.

(Giudice dell'appello)

L'appello contro le sentenze del pretore e del tribunale si propone rispettivamente al tribunale e alla corte di appello nella cui circoscrizione ha sede il giudice che ha pronunciato la sentenza.

L'appello contro le sentenze del giudice di pace si propone al tribunale nel cui circondario ha sede il giudice che ha pronunciato la sentenza."

398 Nesse sentido, o artigo 61 da Constitution de la République Française e o artigo 17 da Ordonnance $n^{\circ} 58$ 1067, lei orgânica do Conseil Constitutionnel.

"Article 61.

Les lois organiques, avant leur promulgation, les propositions de loi mentionnées à l'article 11 avant qu'elles ne soient soumises au référendum, et les règlements des assemblées parlementaires, avant leur mise en application, doivent être soumis au Conseil constitutionnel qui se prononce sur leur conformité à la Constitution.

Aux mêmes fins, les lois peuvent être déférées au Conseil constitutionnel, avant leur promulgation, par le Président de la République, le Premier ministre, le Président de l'Assemblée nationale, le Président du Sénat ou soixante députés ou soixante sénateurs. 
constitucionalidade de uma norma, quando essa é questionada em sede judicial ${ }^{399}$. Também é o órgão responsável pela fiscalização das eleições na França ${ }^{400}$.

A Cour de Cassation é responsável pelo julgamento do recurso de cassação na França ${ }^{401}$, espécie recursal em que se veda a discussão de questões de fato ${ }^{402}$, nos moldes dos recursos extraordinários em sentido amplo ${ }^{403}$.

Sendo assim, também na França não se verifica competência originária ${ }^{404}$ ou recursal ordinária dos tribunais de sobreposição, o que evidencia que não há instrumento processual análogo ao recurso ordinário constitucional naquele ordenamento jurídico.

Portugal apresentou, há séculos, um recurso que permitiu a ampla análise de fatos pelos tribunais superiores: a sopricação, nome dessa espécie recursal durante a vigência das Ordenações Afonsinas ${ }^{405}$, ou o agravo ordinário, denominação aplicada a partir das

Dans les cas prévus aux deux alinéas précédents, le Conseil constitutionnel doit statuer dans le délai d'un mois. Toutefois, à la demande du Gouvernement, s'il y a urgence, ce délai est ramené à huit jours.

Dans ces mêmes cas, la saisine du Conseil constitutionnel suspend le délai de promulgation.”

"Article 17.

Les lois organiques adoptées par le Parlement sont transmises au Conseil constitutionnel par le premier ministre. La lettre de transmission indique, le cas échéant, qu'il y a urgence.

Les règlements et les modifications aux règlements adoptés par l'une ou l'autre assemblée sont transmis au Conseil constitutionnel par le président de l'assemblée."

399 Assim dispõe o artigo 61-1 da Constitution de la République Française:

"Article 61-1.

Lorsque, à l'occasion d'une instance en cours devant une juridiction, il est soutenu qu'une disposition législative porte atteinte aux droits et libertés que la Constitution garantit, le Conseil constitutionnel peut être saisi de cette question sur renvoi du Conseil d'État ou de la Cour de cassation qui se prononce dans un délai déterminé.

Une loi organique détermine les conditions d'application du présent article."

Os artigos 23-1 a 23-7 da Ordonnance $n^{\circ}$ 58-1067 também disciplinam essa remessa da questão constitucional para a apreciação do Conseil Constitutionnel.

${ }^{400}$ Artigos 30 a 51 da Ordonnance $n^{\circ} 58-1067$, lei orgânica do Conseil Constitutionnel.

401 Assim dispõe o artigo 604 do Code de procédure civile:

"Article 604.

Le pourvoi en cassation tend à faire censurer par la Cour de cassation la non-conformité du jugement qu'il attaque aux règles de droit."

${ }^{402}$ No sítio eletrônico da Cour de Cassation, a primeira informação é que esse tribunal não aprecia questões de fato:

"La Cour de cassation est la plus haute juridiction de l'ordre judiciaire français. Elle a été précédée par le Tribunal de cassation, mis en place par l'Assemblée Constituante en 1790 pendant la Révolution Française.

Siégeant dans l'enceinte du Palais de Justice de Paris, la Cour de cassation a pour mission de réviser, à la demande des parties, les décisions émanant des tribunaux et cours d'appels, au pénal comme au civil.

La Cour ne tranche que des questions de droit ou d'application du droit, elle ne juge pas les faits. Elle assure ainsi par sa jurisprudence une application harmonieuse des lois. Depuis 1991, la Cour, à la demande des juridictions, leur donne son avis sur des questions de droit nouvelles et complexes se posant dans de nombreux litiges." (Disponível em: <http://www.courdecassation.fr/institution_1/>. Acesso em: 10 fev. 2013. Grifos nossos).

${ }^{403}$ BORÉ, 1980, p. 439; e CALAMANDREI, 1945, pp. 146/147.

${ }^{404}$ Há notícia histórica de que a Cour de Cassation, em seus primórdios, já possuiu competência originária para julgar juízes em ações de responsabilidade civil. Mas essa competência já foi revogada a muito anos (CALAMANDREI, 1945, p. 148).

${ }^{405}$ CRUZ E TUCCI e AZEVEDO, 2009, p. 204. 
Ordenações Manuelinas ${ }^{406}$. Esse recurso era interposto contra as sentenças proferidas por sobrejuízes, ouvidores ou corregedores, magistrados esses que atuavam em segundo grau, permitindo que o tribunal máximo reexaminasse amplamente essa sentença ${ }^{407}$.

A sopricação ou agravo ordinário não é um antecedente histórico do recurso ordinário constitucional, pois esse recurso foi criado como forma de concentrar poder no monarca, permitindo o acesso à sua palavra final em diversas hipóteses e evitando a prática de arbítrios pelos nobres que integravam as cortes inferiores ${ }^{408}$. Já o recurso ordinário constitucional, conforme exposto anteriormente (Capítulo 4), foi criado para suprir a ausência da Justiça Federal, no início do Brasil republicano, e persiste até hoje como forma de garantir ao cidadão a tutela dos seus direitos fundamentais e de respeito à soberania de Estados estrangeiros e organismos internacionais. Não há semelhança entre as razões de criação de uma e de outra espécie recursal, portanto.

O agravo ordinário foi abolido do ordenamento jurídico lusitano em $1832^{409}$ e, desde então, não foi criado outro recurso que permita que as cortes máximas reexaminem matéria de fato.

Atualmente, a organização judiciária portuguesa é bastante similar à italiana. Há o Tribunal Constitucional, órgão que não integra o Poder Judiciário e que tem competência para garantir o respeito à Constituição da República Portuguesa ${ }^{410}$, e o Supremo Tribunal de Justiça, órgão máximo na hierarquia do Judiciário português ${ }^{411}$.

\footnotetext{
${ }^{406}$ Idem, pp. 206 e 208.

407 Idem, pp. $237 / 238$.

408 "Firmes no propósito de impor a observância da legislação em todo o território do reino, as ordenações de D. Dinis evidenciam que o monarca tinha plena consciência da indelegabilidade do poder, ínsito à sua posição de detentor da 'justiça maior'.

Assim, para pôr fim aos abusos dos senhores que não poucas vezes impediam o recurso de alcançar os juízes superiores, determina que a apelação fosse encaminhada diretamente a 'El Rey' (Livro das Leis e Posturas, p. 51 e 187-188).

Além disso, norteado, por certo, nesta concepção do poder real, numa lei passada em Santarém, em 1302, D. Dinis, reconhecendo o grande e reputado saber jurídico dos sobrejuízes e ouvidores, introduz a inapelabilidade das sentenças por eles proferidas, mas estabelece, mediante o recolhimento de 500 soldos aos cofres públicos, a possibilidade de a parte interpor a sopricação ao rei: (...)” Idem, p. 237.

${ }^{409}$ Idem, pp. 243/244.

${ }^{410}$ Nesse sentido, o artigo 223 da Constituição da República Portuguesa:

"Artigo 223. Competência.

1. Compete ao Tribunal Constitucional apreciar a inconstitucionalidade e a ilegalidade, nos termos dos artigos $277 .^{\circ}$ e seguintes.

2. Compete também ao Tribunal Constitucional:

a) Verificar a morte e declarar a impossibilidade física permanente do Presidente da República, bem como verificar os impedimentos temporários do exercício das suas funções;

b) Verificar a perda do cargo de Presidente da República, nos casos previstos no n. ${ }^{\circ} 3$ do artigo $129 .{ }^{\circ}$ e no n. 3 do artigo $130 .^{\circ}$;

c) Julgar em última instância a regularidade e a validade dos actos de processo eleitoral, nos termos da lei;

d) Verificar a morte e declarar a incapacidade para o exercício da função presidencial de qualquer candidato a Presidente da República, para efeitos do disposto no n. ${ }^{\circ} 3$ do artigo 124..$^{\circ}$;
} 
O Tribunal Constitucional português conhece alegações de fato apenas em matéria eleitoral, pois é o órgão responsável por fiscalizar a lisura das eleições e proclamar seu resultado $^{412}$. Tem as mesmas funções que o Conseil Constitutionnel francês em relação a essa matéria. Mas não se verifica nenhuma hipótese em que julgue, por competência originária ou recursal ordinária, matéria de fato que não se refira a direito eleitoral.

Por outro lado, o Supremo Tribunal de Justiça possui competência originária em casos análogos aos do Supremo Tribunal Federal e do Superior Tribunal de Justiça. É ele o tribunal competente para: (i) julgar o Presidente da República, o Presidente de Assembleia Nacional e o Primeiro-Ministro pelos crimes por eles praticados durante o exercício dessas funções (artigo 35, I, a, da Lei no 3/99, a chamada Lei de Organização e Funcionamento dos Tribunais Judiciais); (ii) julgar processos em que se apura a prática de crime pelos integrantes do próprio Supremo Tribunal de Justiça, dos tribunais de relação e dos integrantes do Ministério Público que atuem perante essas cortes (artigo 36, $b$, do referido diploma legal); (iii) julgar quaisquer processos ajuizados em face dessas mesmas pessoas (artigo 36, c, do referido diploma legal); e (iv) julgar habeas corpus e revisões criminais, em determinados casos (artigo 36, $f$ e $g$, do referido diploma legal) ${ }^{413}$.

A maior parte desses casos é de competência do Supremo Tribunal de Justiça por razão política de harmonia entre os Poderes, motivo diverso daquele que justifica a existência do recurso ordinário constitucional na ordem jurídica brasileira. Exceção é a competência para o julgamento de habeas corpus e de revisão criminal, essa sim ligada à tutela do direito de liberdade por tribunal de sobreposição.

e) Verificar a legalidade da constituição de partidos políticos e suas coligações, bem como apreciar a legalidade das suas denominações, siglas e símbolos, e ordenar a respectiva extinção, nos termos da Constituição e da lei; f) Verificar previamente a constitucionalidade e a legalidade dos referendos nacionais, regionais e locais, incluindo a apreciação dos requisitos relativos ao respectivo universo eleitoral;

g) Julgar a requerimento dos Deputados, nos termos da lei, os recursos relativos à perda do mandato e às eleições realizadas na Assembleia da República e nas Assembleias Legislativas das regiões autónomas;

h) Julgar as acções de impugnação de eleições e deliberações de órgãos de partidos políticos que, nos termos da lei, sejam recorríveis.

3. Compete ainda ao Tribunal Constitucional exercer as demais funções que lhe sejam atribuídas pela Constituição e pela lei."

${ }^{411}$ Conforme determina o artigo 210, $\S 1^{\circ}$, da Constituição da República Portuguesa:

"Artigo 210. Supremo Tribunal de Justiça e instâncias.

1. O Supremo Tribunal de Justiça é o órgão superior da hierarquia dos tribunais judiciais, sem prejuízo da competência própria do Tribunal Constitucional."

${ }^{412}$ Além do já citado artigo 223 da Constituição da República Portuguesa, assim também dispõe os artigos $6^{\circ}$ a 11-A da Lei $n^{\circ}$ 28/82, que disciplina a organização, o funcionamento e o processo do Tribunal Constitucional.

${ }^{413}$ Além disso, também decide conflitos de competência e de atribuição (artigos 35, $\S 2^{\circ}$, e 36, alíneas $d$, e e $h$ da Lei $\left.n^{\circ} 3 / 99\right)$. 
Não é vedada a criação de um recurso que permita ao Supremo Tribunal de Justiça reexaminar fatos, ou mesmo que o dote de competência para julgar apelação ${ }^{414}$. Mas, em regra, o Supremo Tribunal de Justiça não conhece de matéria fática ${ }^{415}$, apenas de matéria de direito não constitucional, já que a competência para analisar esse ramo do direito é do Tribunal Constitucional.

Portanto, ainda que as funções dos tribunais de sobreposição de Portugal sejam mais semelhantes às das altas cortes brasileiras, ainda assim não se verifica um recurso ordinário em sentido amplo que seja dirigido a eles, em matéria cível. A única semelhança entre as altas cortes portuguesas e as brasileiras é a competência do Supremo Tribunal de Justiça para analisar habeas corpus e revisões criminais, processos umbilicalmente ligados à defesa de direito fundamental do cidadão.

A Espanha também possui o seu Tribunal Constitucional, órgão responsável pela proteção à Constitución Española e que não integra o Poder Judiciário ${ }^{416}$, e o Tribunal Supremo, órgão de cúpula do Judiciário, ambos com jurisdição em todo o país ${ }^{417}$.

\footnotetext{
${ }^{414}$ Conforme disposto no artigo 225 do Código de Processo Civil português:

“ARTIGO 225. Espécies no Supremo.

No Supremo Tribunal há as seguintes espécies:

1. ${ }^{a}$ Revistas;

2. ${ }^{\mathrm{a}}$ Recursos em processo penal;

3. ${ }^{\text {a }}$ Conflitos;

4. Apelações;

5. " Causas de que o tribunal conhece em única instância."

${ }^{415}$ Nesse sentido, o artigo 26 da Lei no 3/99, a chamada Lei de Organização e Funcionamento dos Tribunais Judiciais:

"Artigo 26. Poderes de cognição.

Fora dos casos previstos na lei, o Supremo Tribunal de Justiça apenas conhece de matéria de direito."

${ }^{416}$ Assim prevê o artigo 161 da Constitución Española:

"Artículo 161.
}

1. El Tribunal Constitucional tiene jurisdicción en todo el territorio español y es competente para conocer:

a) Del recurso de inconstitucionalidad contra leyes y disposiciones normativas con fuerza de ley. La declaración de inconstitucionalidad de una norma jurídica con rango de ley, interpretada por la jurisprudencia, afectará a ésta, si bien la sentencia o sentencias recaídas no perderán el valor de cosa juzgada.

b) Del recurso de amparo por violación de los derechos y libertades referidos en el artículo 53, 2, de esta Constitución, en los casos y formas que la ley establezca.

c) De los conflictos de competencia entre el Estado y las Comunidades Autónomas o de los de éstas entre sí.

d) De las demás materias que le atribuyan la Constitución o las leyes orgánicas.

2. El Gobierno podrá impugnar ante el Tribunal Constitucional las disposiciones y resoluciones adoptadas por los órganos de las Comunidades Autónomas. La impugnación producirá la suspensión de la disposición o resolución recurrida, pero el Tribunal, en su caso, deberá ratificarla o levantarla en un plazo no superior a cinco meses."

${ }^{417}$ Nos termos do artigo 123 da Constitución Española:

"Artículo 123.

1. El Tribunal Supremo, con jurisdicción en toda España, es el órgano jurisdiccional superior en todos los órdenes, salvo lo dispuesto en materia de garantías constitucionales.

2. El Presidente del Tribunal Supremo será nombrado por el Rey, a propuesta del Consejo General del Poder Judicial, en la forma que determine la ley." 
O Tribunal Constitucional, além de julgar os recursos em que se argue violação à Constituição, também é competente para julgar conflitos de competência e atribuição entre o Estado central e as Comunidades Autônomas, ou entre duas ou mais destas, mas sempre com um viés de controle de constitucionalidade ou de respeito à Norma Maior ${ }^{418}$.

A exceção a essa competência é o recurso de amparo, que se presta a verificar a violação a direitos e liberdades políticas de cidadão espanhol ${ }^{419}$. O recurso de amparo é instrumento processual bastante similar ao mandado de segurança brasileiro, sendo previsto pela grande maioria dos ordenamentos jurídicos dos países de língua espanhola ${ }^{420}$.

Ao julgar o recurso de amparo, o Tribunal Constitucional examina matéria de fato, mas não possibilita a dilação probatória. Isso porque, assim como o mandado de segurança, a prova que aparelha o recurso de amparo é documental e pré-constituída ${ }^{421}$.

Já o Tribunal Supremo é a corte responsável pelo julgamento dos recursos extraordinários em sentido amplo (casación, revisión, etc $)^{422}$, recursos esses que a doutrina aponta como responsáveis pelo exercício da função nomofilática e pela guarda do ordenamento jurídico infraconstitucional ${ }^{423}$.

Além desses casos, também exerce competência originária (i) em ações de responsabilidade civil por atos realizados durante o exercício de cargos políticos, como os de Presidente, de Presidente do Congresso e do Senado, de Presidente do Tribunal Supremo e do Consejo General del Poder Judicial, de Presidente do Tribunal Constitucional, de deputado ou senador etc (artigo 56, $\S \S 2^{\circ}$ e $3^{\circ}$, da Ley Orgánica $n^{\circ}$ 6/1985, que trata da competência dos

\footnotetext{
${ }^{418}$ Além do já citado artigo 161 da Constitución Española, também há previsão nesse sentido no artigo $2^{\circ}$ da Lei Orgânica do Tribunal Constitucional (Ley Orgánica nº 2/1979).

${ }^{419} \mathrm{O}$ recurso de amparo está previsto no artigo $161, b$, da Constitución Española, bem como no artigo $2^{\circ}$, $\S 1^{\circ}$, b, da Ley Orgánica n$^{\circ}$ 2/1979. Seu procedimento é regido pelos artigos 41 a 49 da Ley Orgánica no 2/1979.

${ }^{420}$ DINAMARCO, 2010, pp. 192/193.

${ }^{421}$ Conforme disposição do artigo 49 da Ley Orgánica nº 2/1979:

"Artículo 49.

Uno. El recurso de amparo constitucional se iniciará mediante demanda en la que se expondrán con claridad y concisión los hechos que la fundamenten, se citarán los preceptos constitucionales que se estimen infringidos y se fijará con precisión el amparo que se solicita para preservar o restablecer el derecho o libertad que se considere vulnerado. En todo caso, la demanda justificará la especial trascendencia constitucional del recurso.

Dos. Con la demanda se acompañaran:

a. El documento que acredite la representación del solicitante del amparo.

b. En su caso, la copia, traslado o certificación de la resolución recaída en el procedimiento judicial o administrativo.

Tres. A la demanda se acompañaran también tantas copias literales de la misma y de los documentos presentados como partes en el previo proceso, si lo hubiere, y una más para el Ministerio Fiscal.

Cuatro. De incumplirse cualquiera de los requisitos establecidos en los apartados que anteceden, las Secretarías de Justicia lo pondrán de manifiesto al interesado en el plazo de 10 días, con el apercibimiento de que, de no subsanarse el defecto, se acordará la inadmisión del recurso."

${ }_{422}$ Assim determinam os artigos 56, 57, 58 e 61 da Ley Orgánica n n $^{\circ}$ 6/1985, que trata da competência dos diversos órgãos integrantes do Poder Judiciário espanhol.

${ }^{423}$ FERNÁNDEZ, 1998, p. 391.
} 
diversos órgãos integrantes do Poder Judiciário espanhol); (ii) quaisquer outras ações cíveis ajuizadas em face dessas pessoas (artigo 57, $\S \S 2^{\circ}$ e $3^{\circ}$, do referido diploma legal); (iii) recursos contenciosos-administrativos contra atos de um dos três Poderes (artigo 58, $\S 1^{\circ}$, do referido diploma legal); (iv) das ações de responsabilidade por atos exercidos durante o cargo de magistrado do próprio Tribunal Supremo, bem como todas as ações ajuizadas em face dos seus integrantes (artigo 61, $\S 3^{\circ}$ e $4^{\circ}$, do referido diploma legal); e (v) de processos que tratem da legalidade de criação de partido político (artigo 61, $\S 6^{\circ}$, do referido diploma legal). Mais uma vez se verifica o caráter político da atribuição dessa competência a tribunal superior.

A Espanha atribui ao seu mais importante tribunal de sobreposição, o Tribunal Constitucional, competência para julgar um instrumento processual que também garante a proteção de direitos fundamentais e liberdades individuais do cidadão, o recurso de amparo. Essa competência permite o reexame de fatos, mas apenas da prova documental e préconstituída, como também ocorre no mandado de segurança, por exemplo.

Dessa forma, há pelo menos um ordenamento jurídico europeu, a Espanha, que atribui ao seu tribunal constitucional a competência análoga a que o Supremo Tribunal Federal e o Superior Tribunal de Justiça possuem quando julgam recurso ordinário constitucional em ações constitucionais não penais, sendo a semelhança maior quando o recurso ordinário constitucional é interposto em mandado de segurança.

A Argentina possui apenas um tribunal no topo da hierarquia jurisdicional, que é a Corte Suprema ${ }^{424}$. Não há um tribunal constitucional de modelo clássico e também não se divide a competência para apreciar direito constitucional e infraconstitucional entre duas cortes distintas, concentrando-se a competência apenas na Corte Suprema.

A competência desse tribunal é bastante extensa, sendo muitíssimo similar à competência dos tribunais superiores brasileiros.

Originariamente, a Corte Suprema é competente para julgar (i) causas em que se discute interesse de embaixador, ministro ou cônsul estrangeiro, bem como aquelas envolvendo os demais membros de delegação estrangeira, os familiares de todos os anteriores e os seus empregados domésticos (artigos 116 e 117 da Constitución Nacional Argentina, artigo $2^{\circ}$ da Ley $n^{\circ} 4.055 / 1902$ c.c. artigo $1^{\circ}$, $\S \S 3^{\circ}$ e $4^{\circ}$, da Ley $n^{\circ} 48 / 1863$ e artigo $24, \S 1^{\circ}$, do Decreto-Ley $\mathrm{n}^{\mathrm{o}}$ 1.285/1958); (ii) causas em que alguma Província argentina for parte,

\footnotetext{
${ }^{424}$ Assim dispõe o artigo 108 da Constitución Nacional Argentina:

"Art. 108. El Poder Judicial de la Nación será ejercido por una Corte Suprema de Justicia, y por los demás tribunales inferiores que el Congreso estableciere en el territorio de la Nación."
} 
incluindo aquelas em que a parte contrária for Estado ou cidadão estrangeiro (artigos 116 e 117 da Constitución Nacional Argentina, artigo $2^{\circ}$ da Ley n ${ }^{\circ} 4.055 / 1902$ c.c. artigo $1^{\circ}, \S \S 1^{\circ}$ e $2^{\circ}$, da Ley $\mathrm{n}^{\mathrm{o}} 48 / 1863$ e artigo 24, $\S 1^{\circ}$, do Decreto-Ley $\mathrm{n}^{\circ} 1.285 / 1958$ ); e (iii) diversos conflitos de competência (artigo $9^{\circ}$ da Ley $\mathrm{n}^{\circ} 4.055 / 1902$ e artigo $24, \S 7^{\circ}$, do Decreto-Ley $\mathrm{n}^{\circ}$ $1.285 / 1958)$.

Tem competência recursal ordinária nos seguintes casos: (i) causas que envolvam o almirantado ou jurisdição marítima (artigo 116 da Constitución Nacional Argentina, artigo 3º, $\S 3^{\circ}$, da Ley $\mathrm{n}^{\mathrm{o}} 4.055 / 1902$ e artigo $24, \S 6^{\circ}, c$, do Decreto-Ley $\mathrm{n}^{\circ} 1.285 / 1958$ ); (ii) causas em que o Estado argentino for parte, desde que seu valor de alçada seja superior a $\$$ 200.000.000,00 (duzentos milhões de pesos argentinos) (artigo 116 da Constitución Nacional Argentina, artigo $3^{\circ}, \S 1^{\circ}$, da Ley $\mathrm{n}^{\mathrm{o}} 4.055 / 1902$ e artigo $24, \S 6^{\circ}$, a, do Decreto-Ley $\mathrm{n}^{\mathrm{o}}$ 1.285/1958); (iii) causas fiscais, acima de um determinado valor de alçada (artigo $3^{\circ}, \S 2^{\circ}$, da Ley $\left.\mathrm{n}^{\mathrm{o}} 4.055 / 1902\right)^{425}$; (iv) as extradições criminais requeridas por Estado estrangeiro (artigo $3^{\mathrm{o}}, \S 4^{\mathrm{o}}$, da Ley $\mathrm{n}^{\mathrm{o}} 4.055 / 1902$ e artigo $24, \S 6^{\circ}$, b, do Decreto-Ley $\mathrm{n}^{\mathrm{o}} 1.285 / 1958$ ); (v) nas causas criminais em que se apure a prática de crimes políticos ${ }^{426} \mathrm{e}$ em outros crimes em que a pena imposta exceda 10 (dez) anos de prisão (artigo $3^{\circ}, \S 5^{\circ}$, da Ley $n^{\circ} 4.055 / 1902$ ); e (vi) os recursos de queixa por retardo de justiça, interpostos contra as câmaras nacionais de apelação (artigo 24, § 5 $5^{\circ}$, do Decreto-Ley $\mathrm{n}^{\mathrm{o}} 1.285 / 1958$ ).

Por fim, também possui competência recursal extraordinária, para verificar a validade de normas jurídicas, tratados internacionais ou decisões judiciais frente à Constitución Nacional Argentina (artigo 14 da Ley $\mathrm{n}^{\circ} 48 / 1863$ c.c. artigo $6^{\circ}$ da Ley $\mathrm{n}^{\circ} 4.055 / 1902$ e c.c. artigo 24, § $2^{\circ}$, do Decreto-Ley $\mathrm{n}^{\mathrm{o}} 1.285 / 1958$ ).

Também na Argentina há a figura do amparo, mas, neste caso, regulada como ação autônoma, não como recurso ${ }^{427}$. No entanto, não se encontrou nenhuma disposição específica

\footnotetext{
${ }^{425}$ O dispositivo legal prevê o seguinte valor de alçada: 7.265.233.203,08 (sete bilhões, duzentos e sessenta e cinco milhões, duzentos e trinta e três mil duzentos e três vírgula oito) Australes. Não se sabe quanto é essa quantia atualmente em pesos argentinos, reais ou qualquer outra moeda.

${ }_{426}$ Os crimes previstos pela lei são os seguintes: "traición, rebelión, sedición y en las de homicidio, incendio o explosión, piratería y naufragios cometidos en alta mar a bordo de buques nacionales o por piratas extranjeros".

${ }^{427}$ Previsão essa que se encontra no artigo 43 da Constitución Nacional Argentina:

"Art. 43. Toda persona puede interponer acción expedita y rápida de amparo, siempre que no exista otro medio judicial más idóneo, contra todo acto u omisión de autoridades públicas o de particulares, que en forma actual o inminente lesione, restrinja, altere o amenace, con arbitrariedad o ilegalidad manifiesta, derechos y garantías reconocidos por esta Constitución, un tratado o una ley. En el caso, el juez podrá declarar la inconstitucionalidad de la norma en que se funde el acto u omisión lesiva.

Podrán interponer esta acción contra cualquier forma de discriminación y en lo relativo a los derechos que protegen al ambiente, a la competencia, al usuario y al consumidor, así como a los derechos de incidencia colectiva en general, el afectado, el defensor del pueblo y las asociaciones que propendan a esos fines, registradas conforme a la ley, la que determinará los requisitos y formas de su organización.
} 
que atribua competência à Corte Suprema para julgar as ações de amparo, seja por competência originária, seja por meio de recurso ordinário em sentido amplo.

Assim como se dá no Brasil, na Argentina é a Corte Suprema a responsável por julgar causas envolvendo Estados estrangeiros ou seus representantes (embaixadores, cônsules, etc), seja em competência originária, seja em competência recursal ordinária (caso este da extradição); e casos que envolvam crimes políticos, estes só pela via recursal ordinária.

A Corte Suprema é competente para julgar diversos outros casos, seja por razões políticas, como os conflitos de competência e atribuição e as ações que envolvam direito marítimo, seja por razões de maior proteção à Fazenda Pública, como as causas de alçada em que for parte a Argentina ou o fisco argentino.

Mas apenas se verifica a atribuição de competência à Corte Suprema com o viés de proteção a direitos fundamentais e liberdades individuais no tocante à competência recursal ordinária para casos em que a pena imposta pela prática de crime é superior a 10 (dez) anos de prisão. Como mencionado anteriormente, não há competência originária ou recursal ordinária para a ação de amparo ou para habeas corpus.

Dessa forma, conclui-se que a Argentina se assemelha muito ao Brasil quando prevê competências originária e recursal ordinária à sua Corte Suprema para julgar casos em que Estado (e até mesmo cidadão) estrangeiro tenha interesse, e em processos que tratem de crime político, mas não há grande semelhança quanto à proteção dos direitos fundamentais e das liberdades individuais pelo órgão de cúpula do Judiciário argentino.

O último ordenamento jurídico estrangeiro que será analisado nesta dissertação é o do Uruguai.

Diferentemente do Brasil, o Uruguai divide sua jurisdição em judicial e contenciosaadministrativa. O órgão de cúpula da jurisdição judicial é a Suprema Corte de Justicia ${ }^{428}$, que, assim como a Corte Suprema argentina, é o único tribunal responsável por examinar violação à Constitución de la República Uruguaya e à legislação infraconstitucional.

\footnotetext{
Toda persona podrá interponer esta acción para tomar conocimiento de los datos a ella referidos y de su finalidad, que consten en registros o bancos de datos públicos, o los privados destinados a proveer informes, y en caso de falsedad o discriminación, para exigir la supresión, rectificación, confidencialidad o actualización de aquéllos. No podrá afectarse el secreto de las fuentes de información periodística.

Cuando el derecho lesionado, restringido, alterado o amenazado fuera la libertad física, o en caso de agravamiento ilegítimo en la forma o condiciones de detención, o en el de desaparición forzada de personas, la acción de hábeas corpus podrá ser interpuesta por el afectado o por cualquiera en su favor y el juez resolverá de inmediato, aun durante la vigencia del estado de sitio."

${ }^{428}$ Nesse sentido, o artigo 233 da Constitución de la República Uruguaya:

"Artículo 233. El Poder Judicial será ejercido por la Suprema Corte de Justicia y por los Tribunales y Juzgados, en la forma que estableciere la ley."
} 
Esse exame se dá por meio do recurso de casación, recurso extraordinário em sentido amplo, em que se limita a cognição do juízo ad quem a questões de direito ${ }^{429}$. Também é competente a Suprema Corte de Justicia para julgar os recursos de aclaración y ampliación $^{430}$, análogos aos nossos embargos de declaração, e de revisión ${ }^{431}$, análogo à ação rescisória brasileira. Mas, como pode se perceber, não possui competência recursal ordinária no juízo cível ${ }^{432}$.

Por outro lado, é o tribunal responsável por analisar a consulta, instituto jurídico bastante próximo do reexame necessário brasileiro ${ }^{433}$, em causas criminais ${ }^{434}$.

A competência originária da Suprema Corte de Justicia é extremamente limitada. Esse tribunal julga apenas (i) delitos envolvendo direitos fundamentais; (ii) causas envolvendo questões de almirantado; (iii) causas que versem sobre tratados e convenções internacionais; (iv) causas em que seja parte diplomata estrangeiro (todas essas hipóteses previstas no artigo 239, § $1^{\circ}$, da Constitución de la República Uruguaya); e (v) os conflitos de competência entre os órgão do Poder Judiciário e do Contencioso-Administrativo (artigo 55, $\S 1^{\circ}$, da Ley $\mathrm{n}^{\mathrm{o}}$ 15.750/1985, a Ley Organica de la Judicatura y de Organizacion de los Tribunales).

O Tribunal de lo Contencioso Administrativo é o órgão responsável pelo exame das demandas que tratem da nulidade de atos administrativos ${ }^{435}$ e sobre as divergências e conflitos ocorridos entre o governo central, os Departamentos e pessoas que integrem a administração pública direta e indireta, salvo se se tratar de matéria constitucional ${ }^{436}$.

Também existe a ação de amparo no ordenamento jurídico uruguaio ${ }^{437}$, similar ao mandado de segurança brasileiro. Mas a competência para processar e julgar essa ação originariamente é sempre do juiz de primeiro grau ${ }^{438}$.

\footnotetext{
${ }^{429}$ Assim dispõe o artigo 270 do Código General del Proceso:

“Artículo 270. Causales de casación.

El recurso sólo podrá fundarse en la existencia de una infracción o errónea aplicación de la norma de derecho, sea en el fondo o en la forma. Se entenderá por tal, inclusive, la infracción a las reglas legales de admisibilidad o de valoración de la prueba.

No se tendrán en cuenta los errores de derecho que no determinaren la parte dispositiva de la sentencia.

En cuanto a las normas de procedimiento, sólo constituirá causal la infracción o errónea aplicación de aquellas que sean esenciales para la garantía del debido proceso y siempre que la respectiva nulidad no haya sido subsanada en forma legal."

${ }^{430}$ Conforme artigo 244 do Código General del Proceso.

${ }^{431}$ Nos termos do artigo 283 do Código General del Proceso.

${ }^{432}$ Essa previsão se encontra no artigo 258 do Código General del Proceso.

${ }^{433}$ BARBOSA MOREIRA, 2001, p. 91; TOSTA, 2005, pp. 122/123; e WELSCH, 2010, pp. 33/38.

434 Segundo determina o artigo 55, $\S 2^{\circ}$, da Ley $\mathrm{n}^{\mathrm{o}} 15.750 / 1985$, a Ley Organica de la Judicatura y de Organizacion de los Tribunales.

${ }^{435}$ Nesse sentido a disposição do artigo 309 Constitución de la República Uruguaya.

${ }^{436}$ Conforme disposto no artigo 313 Constitución de la República Uruguaya.

${ }^{437}$ Essa ação está prevista na Ley $n^{\circ} 16.011 / 1988$, cujo artigo $1^{\circ}$ tem a seguinte redação:

"Artículo $1^{\circ}$. Cualquier persona física o jurídica, pública o privada, podrá deducir la acción de amparo contra todo acto, omisión o hecho de las autoridades estatales o paraestatales, así como de particulares que en forma
} 
As competências originária e recursal ordinária da Suprema Corte de Justicia revelam que as preocupações do ordenamento jurídico uruguaio são as mesmas que as do brasileiro: há casos em que a competência é prevista por razões políticas, como nos conflitos de competência entre o Judiciário e o Contencioso-Administrativo, e nas causas que tratam de almirantado; outros em que se respeita a soberania de Estados estrangeiros, como nas ações em que é parte diplomata estrangeiro; alguns em que a competência é fixada com base na proteção de direitos fundamentais, especialmente em matéria criminal, como a consulta; e mais outros em que a competência é fixada pela penalização de crimes políticos, como aqueles em que a corte possui competência originária para julgar delitos envolvendo direitos fundamentais.

O Tribunal de lo Contencioso Administrativo é o responsável pela análise da validade de atos administrativos, o que é matéria que pode ser questionada pela via das ações constitucionais em que pode ser interposto recurso ordinário constitucional. Preocupa-se a Constitución de la República Uruguaya em que esses casos sejam julgados por órgão de alta hierarquia, assim como a nossa Carta Magna faz em alguns casos.

Por outro lado, percebe-se que em nenhuma hipótese a Suprema Corte de Justicia julga ação de amparo como primeiro ou segundo grau de jurisdição, o que é uma diferença em relação à legislação brasileira.

Em suma, feita essa breve análise de alguns ordenamentos jurídicos estrangeiros, é possível concluir que alguns deles, notadamente o português, o espanhol, o argentino e o uruguaio, possuem mecanismos processuais que permitem que os tribunais superiores examinem matéria de fato, seja pela via recursal ordinária, seja em casos de competência originária.

Esses casos têm ligação (i) com a defesa de direitos fundamentais e liberdades individuais, nos casos de Portugal, quando o Supremo Tribunal de Justiça julga habeas corpus e revisão criminal, da Espanha, pelo recurso de amparo, da Argentina, pelo julgamento de apelação em crime em que foi aplicada pena superior a 10 (dez) anos de prisão,

actual o inminente, a su juicio, lesione, restrinja, altere o amenace, con ilegitimidad manifiesta, cualquiera de sus derechos y libertades reconocidos expresa o implícitamente por la Constitución, con excepción de los casos en que proceda la interposición del recurso de 'habeas corpus'.

La acción de amparo no procederá en ningún caso:

a) Contra los actos jurisdiccionales, cualquiera sea su naturaleza y el órgano del que emanen. Por lo que refiere a los actos emanados de los órganos del Poder Judicial, se entiende por actos jurisdiccionales, además de las sentencias, todos los actos dictados por los Jueces en el curso de los procesos contenciosos;

b) Contra los actos de la Corte Electoral, cualquiera sea su naturaleza;

c) Contra las leyes y los decretos de los Gobiernos Departamentales que tengan fuerza de ley en su jurisdicción."

${ }^{438}$ Segundo consta do artigo $3^{\circ}$ da Ley $\mathrm{n}^{\circ} 16.011 / 1988$. 
e do Uruguai, em razão da consulta em casos criminais; (ii) com a apuração de crimes políticos, nos casos da Argentina, pelo julgamento de recurso ordinário em sentido amplo, e do Uruguai, com a competência originária do órgão de cúpula; e (iii) com o respeito à soberania de Estados estrangeiros, também nos casos da Argentina, que estende essa proteção a familiares e a empregados domésticos de estrangeiros em missão diplomática, e até mesmo ao estrangeiro "comum” em certos casos, e do Uruguai, apenas em relação aos diplomatas estrangeiros.

Essas três hipóteses são aquelas em que é cabível o recurso ordinário constitucional brasileiro. Ou seja, as funções às quais essa espécie recursal serve não são esquecidas por ordenamentos jurídicos estrangeiros, o que influencia a conclusão pela manutenção do instituto na legislação nacional.

\subsection{O futuro do recurso ordinário constitucional}

Sendo o recurso ordinário constitucional um recurso heterogêneo ${ }^{439}$, que serve a diferentes fins dependendo da hipótese de cabimento, a análise quanto à manutenção ou exclusão da espécie recursal do ordenamento jurídico brasileiro deve ser feita separadamente, tomando cada uma das hipóteses de cabimento por vez.

\subsubsection{Ações constitucionais}

Entende-se que o recurso ordinário constitucional deve ser mantido nas ações constitucionais - habeas corpus, mandado de segurança, habeas data e mandado de injunção - com redução das hipóteses de cabimento em habeas corpus e ampliação em habeas data.

A proteção aos direitos fundamentais e às liberdades individuais é uma das funções dos tribunais superiores, em especial na América Latina, tão marcada pelas ditaduras militares no século passado ${ }^{440}$. Permitir que eles reexaminem amplamente as decisões denegatórias

\footnotetext{
${ }^{439}$ AMENDOEIRA JR,. 2012, p. 208.

440 "De um modo geral, as Cortes Supremas latino-americanas constituem a cúpula de cada sistema nacional de garantia das liberdades humanas, o que fazem em via recursal - como de resto é natural que assim seja em todos os países do mundo - e também pela competência originária, que algumas Constituições lhes outorgam, de administrar a jurisdição constitucional das liberdades.

(...) Em tempos difíceis da via institucional do país a Corte Suprema de Justicia argentina exerceu essa competência originária para a preservação de direitos, inclusive mediante superação dos óbices até então representados pela natureza política dos atos lesivos. Ela também realiza o controle dos atos eleitorais, superando outra limitação antes respeitada.” (DINAMARCO, 2010, pp. 194/195).
} 
dessas ações constitucionais, pela via do recurso ordinário constitucional, reforça a função de guarda dos direitos fundamentais, não desvirtuando em nada seu papel ${ }^{441}$.

Portugal e Espanha são os dois melhores exemplos, entre os ordenamentos jurídicos estrangeiros examinados nesta dissertação, de proteção aos direitos fundamentais em se atribuindo competência originária ou recursal ordinária aos tribunais superiores. Portugal prevê a competência originária do Supremo Tribunal de Justiça, mais alta corte do seu Poder Judiciário e responsável máximo pela integridade do direito infraconstitucional, para julgar habeas corpus, além de revisão criminal. Já o Tribunal Constitucional espanhol possui competência para julgar o recurso de amparo, instrumento processual bastante próximo do mandado de segurança, permitindo a ampla tutela de direitos fundamentais pelo cidadão frente ao guardião maior da Constitución Española.

Historicamente, o recurso ordinário constitucional sempre esteve ligado à proteção de direitos fundamentais. Desde a Constituição Federal de 1891 até os dias de hoje, com exceção do período entre a vigência do Ato Institucional n n 02/1965 até o advento da Carta Magna de 1967, ele sempre foi cabível em habeas corpus. E pela maior parte da vigência de Constituições Federais marcadas pela visão política democrática, também foi cabível esse recurso em mandado de segurança.

O recurso ordinário constitucional em ações constitucionais está arraigado na cultura jurídica brasileira, devendo ser respeitado esse viés histórico e cultural ao se cogitar pela permanência ou exclusão do instituto jurídico-processual.

Apesar do volume de trabalho representado pelo julgamento de recursos ordinários constitucionais não ser o principal fator para se concluir pela sua manutenção ou não, já que o que importa é verificar se as funções desse recurso são ou não compatíveis com as funções dos tribunais superiores, não se pode descartar essa informação.

Conforme exposto na Introdução (Capítulo 1) deste trabalho, os recursos ordinários constitucionais representam menos de $1 \%$ (um por cento) dos processos distribuídos ao Supremo Tribunal Federal, e aproximadamente 2\% (dois por cento) dos processos

\footnotetext{
441 Por outro lado, há parte da doutrina que critica a competência do Supremo Tribunal Federal para o julgamento de recurso ordinário constitucional, pois não se poderia rebaixar esse tribunal a órgão de segunda instância, dada a sua função de guardião da Constituição:

"Devemos deixar assentado que não se justifica, a nosso ver, a existência de tal recurso no âmbito do Supremo Tribunal Federal. Se este Tribunal deve atuar como 'guarda da Constituição', não vemos razão de ordem sistemática, ou mesmo prática, na existência de um recurso, com devolutividade plena, inclusive com a possibilidade de discussões de matérias infraconstitucional e fática, a ser apreciado por um colegiado que deveria ter suas decisões restritas ao âmbito constitucional." (GOMES JÚNIOR, 2003, p. 477).

Tal crítica não se mostra cabível, vez que as funções de guardião da Constituição Federal e de respeitar os direitos fundamentais não são conflitantes, mas sim complementares, sendo razoável que no caso das ações constitucionais o Supremo Tribunal Federal possa, excepcionalmente, reexaminar matéria de fato.
} 
distribuídos ao Superior Tribunal de Justiça ${ }^{442}$. Ou seja, não é o recurso ordinário constitucional o responsável pelo assoberbamento daquelas cortes, não se podendo argumentar que o funcionamento dos tribunais superiores é prejudicado pelo recurso ordinário constitucional.

Quem é contrário ao recurso ordinário constitucional em ações constitucionais costuma argumentar que ele viola o princípio da igualdade, pois apenas tem cabimento contra decisões denegatórias, não concessivas dos writs $^{443}$.

Respeitada essa posição, não se concorda com ela.

Deve-se interpretar o princípio da igualdade não como igualdade formal, no sentido de tratar a todos igualmente, mas sim pelo prisma da igualdade material, consubstanciada pela máxima aristotélica de "Tratar os iguais igualmente e os desiguais desigualmente, na exata medida da sua desigualdade" ${ }^{444}$.

A igualdade meramente formal, estática, não é mais suficiente para assegurar os princípios e garantias fundamentais do Estado Democrático de Direito. A previsão abstrata de igualdade, sem acompanhar as transformações sociais, econômicas e políticas, é pouco efetiva, devendo ser implementadas medidas práticas para fazer com que todos sejam iguais perante a lei ${ }^{445}$. Daí o conceito de isonomia, pelo qual as diferenças reais entre os litigantes devem ser o mais abrandadas possível ${ }^{446}$.

É dever do legislador criar mecanismos para que a isonomia processual possa ser aplicada na prática, não deixando o resultado do processo apenas à mercê da competência e da vontade das partes ${ }^{447}$.

Sob esse enfoque, o recurso ordinário constitucional não viola a igualdade, mas sim efetiva a isonomia, já que permite que o cidadão, parte muito mais fraca na relação processual em que litiga contra o Estado, tenha acesso ao duplo grau de jurisdição caso sucumba na sua pretensão, equilibrando as forças das partes por meio desse recurso ${ }^{448}$.

\footnotetext{
${ }^{442}$ Vide nota 01.

${ }^{443}$ ORESTE, 1995 , p. 156/157.

${ }^{444}$ SILVA, F., 2011, p. 22.

${ }^{445}$ BEDAQUE, 2011, p. 61.

${ }^{446}$ CINTRA, GRINOVER e DINAMARCO, 2006, pp. 59/60.

${ }^{447}$ BARBOSA MOREIRA, 1986, p. 180.

448 "A previsão do recurso ordinário só em benefício do impetrante não significa qualquer violação ao 'princípio da isonomia' (v. n. 10 do Capítulo 1 da Parte II do vol. 1). O mandado de segurança, o habeas data e o mandado de injunção são medidas judiciais instituídas contras os desmandos do Poder Público ou entidade a ele equiparada (exercício de função pública). Destarte, não há agressão ao 'modelo constitucional do processo civil' na previsão de recurso de fundamentação livre e, por isto mesmo, mais amplo, mais propício para o reexame da decisão recorrida, somente para a parte intrinsecamente mais fraca do processo, o impetrante." (BUENO, 2011, p. 260).

No mesmo sentido: SORMANI, 2008, p. 233.
} 
Concluindo-se pela manutenção do recurso ordinário constitucional em ações constitucionais, resta verificar se ele deve ser mantido em todas elas - habeas corpus, mandado de segurança, mandado de injunção e habeas data - e se a competência atribuída atualmente ao Supremo Tribunal Federal e ao Superior Tribunal de Justiça deve ser alterada.

Não se questiona a manutenção do recurso ordinário constitucional em habeas corpus. Essa ação constitucional tutela um dos mais importantes direitos fundamentais, o de ir, vir e ficar, sendo historicamente a hipótese em que essa espécie recursal teve cabimento por mais tempo ${ }^{449}$.

O Supremo Tribunal Federal apenas julga recurso ordinário constitucional em habeas corpus contra decisão denegatória proferida por tribunal superior em única instância, sendo a sua competência o mais limitada possível neste caso. Não se pode reduzi-la, portanto, tampouco se deve aumenta-la, porque o Superior Tribunal de Justiça, tribunal de sobreposição, mas que não está no topo da hierarquia judiciária brasileira, é a corte mais indicada para julgar recurso ordinário constitucional contra decisão de tribunal ordinário que denegue habeas corpus.

Quando o Superior Tribunal de Justiça julga recurso ordinário constitucional interposto em habeas corpus, pode funcionar como verdadeira terceira instância, se houver sido denegada a segurança pelo juízo de primeiro grau e pelo tribunal, pois pode ser interposto recurso contra decisão de única ou de última instância.

A liberdade de locomoção é um dos mais importantes direitos fundamentais, como já dissemos, mas não merece tratamento diferenciado em relação aos demais direitos fundamentais que são tutelados por mandado de segurança, por exemplo. É possível impetrar mandado de segurança contra ato de hospital público que negue a realização de uma cirurgia imprescindível para a vida de uma pessoa, por exemplo. Neste caso, o writ tutela os direitos fundamentais à vida, à saúde e à dignidade da pessoa humana. Mas, se a competência para apreciar esse mandado se segurança for de juiz de primeiro grau, não se poderá chegar a tribunal superior pela via recursal ordinária, pois o recurso ordinário constitucional dirigido ao Superior Tribunal de Justiça é cabível apenas contra decisão denegatória de mandado de segurança proferida por tribunal ordinário em única instância ${ }^{450}$.

\footnotetext{
${ }^{449}$ ALCIDES DE MENDONÇA LiMA (1976, pp. 223/224) defendia a manutenção do recurso ordinário constitucional apenas em relação a essa ação constitucional.

${ }^{450}$ Há doutrina que defende que os direitos tutelados pelo mandado de segurança não podem ser comparados aos protegidos pelo habeas corpus, advogando a extinção do recurso ordinário constitucional no primeiro caso (CARTAXO, 1960, 773/774; e MENDONÇA LIMA, 1976, pp. 223/224).
} 
Direitos fundamentais tuteláveis pela via do mandado de segurança são tão importantes quanto o direito fundamental de liberdade de locomoção, tutelado pelo habeas corpus, não havendo razão para este último ter proteção mais ampla do que aqueles.

Dessa forma, entende-se que o recurso ordinário constitucional em habeas corpus de competência do Superior Tribunal de Justiça deveria ter sua hipótese de cabimento restringida a decisões denegatórias proferidas por tribunais ordinários em única instância, da mesma forma que o mandado de segurança.

Em mandado de segurança, a disciplina do recurso ordinário constitucional é ideal. Ele efetiva a isonomia processual, por ser cabível só contra decisão denegatória, mas não oferece proteção exagerada ao cidadão, pois é cabível apenas contra decisão de única instância, seja quando é julgado pelo Supremo Tribunal Federal, seja quando julgado pelo Superior Tribunal de Justiça.

Autorizada doutrina considera que o mandado de segurança em si não é mais necessário, dado que as tutelas de urgência, aplicáveis com fungibilidade, podem ser requeridas em qualquer processo, inclusive admitindo produção de prova oral e pericial e imposição de medidas de apoio, como multa cominatória, o que as tornaria inclusive mais vantajosas que o mandado de segurança ${ }^{451}$. O writ teria apenas algumas vantagens procedimentais em relação ao processo comum, o que não seria suficiente para manter a sua previsão no ordenamento jurídico ${ }^{452}$.

Todavia, estando o mandado de segurança previsto como um dos direitos fundamentais na Constituição Federal (artigo 5º LXIX e LXX), essa discussão se torna inútil, pois é cláusula pétrea, que não poderá ser derrogada nem mesmo por emenda constitucional.

Por fim, o recurso ordinário constitucional cabível em mandado de injunção deve ser mantido como está, e devem ser aumentadas as hipóteses de cabimento em habeas data.

Assim como se dá com o recurso ordinário constitucional interposto em mandado de segurança de competência do Supremo Tribunal Federal, não é possível limitar ainda mais as hipóteses de cabimento desse recurso nessas duas ações constitucionais, pois a atual previsão normativa já é no sentido de que o recurso só é cabível quando elas são julgadas em única instância por tribunal superior.

\footnotetext{
${ }^{451}$ TESHEINER, 2010, pp. 02/03.

${ }^{452}$ Entre as vantagens procedimentais do mandado de segurança estão: (i) a competência originária de tribunais; (ii) a limitação da recorribilidade, o que se dá pelo próprio recurso ordinário constitucional; (iii) a prioridade de tramitação; e (iv) a não condenação da parte vencida ao pagamento de honorários advocatícios (TESHEINER, 2010, p. 02).
} 
Pode-se apenas cogitar ampliar as hipóteses de cabimento, concedendo competência do Superior Tribunal de Justiça para julgar recurso ordinário constitucional interposto contra decisão denegatória de mandado de injunção ou habeas data, julgada em única instância por tribunal ordinário.

O mandado de injunção que trate de matéria federal é de competência originária do Supremo Tribunal Federal, quando a elaboração da norma regulamentadora for atribuição do Presidente da República, do Congresso Nacional ou de uma das suas casas, do Tribunal de Contas da União ou de um tribunal superior (artigo 102, I, q, da Constituição Federal); e do Superior Tribunal de Justiça, quando a elaboração da norma regulamentadora for atribuição de órgão, entidade ou autoridade federal integrante da administração direta ou indireta, excetuados os casos de competência de outro tribunal superior ${ }^{453}$ (artigo 105, I, $h$, da Constituição Federal).

Apenas quando o mandado de injunção envolver matéria estadual, distrital ou municipal é que será julgado por Tribunal de Justiça Estadual ou Tribunal de Justiça do Distrito Federal e dos Territórios, originariamente ${ }^{454}$.

Permitir que o Superior Tribunal de Justiça, tribunal federal, examine recurso ordinário constitucional que envolva necessariamente apenas matéria local violaria o princípio federativo, permitindo ingerência da União em assuntos exclusivos dos Estados, por exemplo.

Por isso, consideramos que o cabimento de recurso ordinário constitucional não deve ser ampliado em mandado de injunção, mantendo-se apenas a competência do Supremo Tribunal Federal nesses casos, conforme o atual texto constitucional federal.

O habeas data impetrado contra ato do Presidente da República, das Mesas do Senado e da Câmara dos Deputados, do Tribunal de Contas da União, do Procurador-Geral da República e do Supremo Tribunal Federal são julgados originariamente por este tribunal (artigo 102, I, $d$, da Constituição Federal). O Superior Tribunal de Justiça possui competência originária para julgar habeas data contra ato de Ministro de Estado, de Comandante das Forças Armadas e do próprio tribunal (artigo 105, I, $b$, da Constituição Federal). O Superior

\footnotetext{
453 Apesar dessa exceção constitucional, não há outra norma jurídica que preveja competência do Tribunal Superior do Trabalho, do Tribunal Superior Eleitoral ou do Superior Tribunal Militar para julgarem originariamente mandado de injunção.

${ }^{454}$ Nesse sentido, por exemplo, o artigo 74, V, da Constituição do Estado de São Paulo:

“Artigo 74. Compete ao Tribunal de Justiça, além das atribuições previstas nesta Constituição, processar e julgar originariamente:

(...) V - os mandados de injunção, quando a inexistência de norma regulamentadora estadual ou municipal, de qualquer dos Poderes, inclusive da administração indireta, torne inviável o exercício de direitos assegurados nesta Constituição;"
} 
Tribunal Militar julga originariamente habeas data contra ato da Justiça Militar (artigos $6^{\circ}$, I, $c$, da Lei $\mathrm{n}^{\mathrm{o}}$ 8.457/1992 e 99 do Regimento Interno do Superior Tribunal Militar). ${ }^{455}$

Com exceção dos casos de competência originária do Supremo Tribunal Federal, irrecorríveis, em todos os outros é cabível recurso ordinário constitucional se a decisão do tribunal superior for denegatória.

No entanto, também são competentes para julgar habeas data os Tribunais Regionais Federais, quando o ato impugnado for proferido pelo próprio tribunal ou por juiz federal (artigo 20, I, c da Lei $\mathrm{n}^{\circ}$ 9.507/1997); os juízes federais, quando o ato impugnado tiver sido proferido por autoridade federal, excetuada a competência de outros tribunais (artigo 20, I, $d$, da Lei no 9.507/1997); e os Tribunais Estaduais e os juízes de direito, nos demais casos, conforme as Constituições dos Estados (artigo 20, I, $d$ e $e$, da Lei n ${ }^{\circ}$ 9.507/1997).

Ora, não há possibilidade de duplo grau de jurisdição nos casos de competência originária dos Tribunais Regionais Federais, mesmo havendo tribunal federal de nível hierárquico superior que pudesse efetivar esse princípio. Não há justificativa para tratar os casos de competência originária dos Tribunais Regionais Federais de forma diversa dos demais casos de competência da Justiça Federal, havendo inclusive a incongruência de ser permitido o amplo reexame em habeas data impetrado contra ato de juiz federal militar, pelo Superior Tribunal Militar, mas não contra ato de juiz federal "não militar".

Nos casos de competência originária de juiz federal o duplo grau de jurisdição é exercido por meio de apelação dirigida aos Tribunais Regionais Federais, não havendo necessidade de um terceiro grau de jurisdição, pelos mesmos motivos já expostos quando se analisou o habeas corpus. E para as hipóteses de competência da Justiça Estadual também não é possível recurso a tribunal superior, pelas razões apresentadas quando se tratou do mandado de injunção.

Assim, considera-se que deve ser cabível recurso ordinário constitucional, dirigido ao Superior Tribunal de Justiça, contra acórdão denegatório de habeas data de competência originária de Tribunal Regional Federal.

Para efetivar as conclusões acima expostas, é necessária a alteração da Constituição Federal $^{456}$, não sendo possível aplicar essa interpretação de lege lata.

\footnotetext{
${ }^{455}$ Não se encontrou competência originária do Tribunal Superior Eleitoral e do Tribunal Superior do Trabalho para julgar habeas data.

${ }^{456} \mathrm{O}$ artigo 20 da Lei $\mathrm{n}^{\circ}$ 9.507/1997 tentou, ao que parece, criar essa hipótese de cabimento de recurso ordinário constitucional. Mas, conforme explicitado no item 5.1.3 desta dissertação, a alteração da competência do Superior Tribunal de Justiça apenas pode ser realizada por meio de emenda constitucional, devendo essa norma ser interpretada como a reiteração do cabimento de recurso especial neste caso.
} 


\subsubsection{Causas internacionais}

Diferentemente das ações constitucionais, não se considera necessária a previsão do recurso ordinário constitucional para as causas internacionais.

A criação dessa subespécie de recurso ordinário constitucional, tão semelhante aos já existentes recursos de apelação e de agravo, seria justificada pela importância da causa, que envolve Estado estrangeiro ou organismo internacional ${ }^{457458}$. Daí a necessidade do Superior Tribunal de Justiça funcionar como corte de revisão.

Argentina e Uruguai também atribuem aos seus tribunais superiores competência originária e recursal ordinária para julgar causas em que há interesse de Estado ou cidadão estrangeiro. A Argentina o faz em muitos casos. Originariamente, causas em que se discute interesse de embaixador, ministro ou cônsul estrangeiro, bem como aquelas envolvendo os demais membros de delegação estrangeira, os familiares de todos os anteriores e os seus empregados domésticos; e causas em que alguma Província argentina seja parte, de um lado, e Estado ou cidadão estrangeiro o sejam, de outro. E, em sede recursal ordinária, as extradições criminais requeridas por Estado estrangeiro. Já o Uruguai limita a competência do seu tribunal de cúpula às causas em que seja parte diplomata estrangeiro, julgadas originariamente.

Respeitados os entendimentos doutrinários contrários e as previsões de ordenamentos jurídicos estrangeiros, discorda-se dessa posição.

Não se mostra necessário que tribunal superior funcione como órgão de segundo grau tão somente pelo fato de Estado estrangeiro ou organismo internacional ser parte na ação ${ }^{459}$. Os Tribunais Regionais Federais têm plena capacidade de julgar os recursos nestes casos, não

\footnotetext{
457 “(...) Realmente, diante da importância da causa, o constituinte brasileiro optou pela realização do duplo grau de jurisdição pelo Superior Tribunal de Justiça em sede de recurso ordinário, cabendo, posteriormente, recurso extraordinário para o Supremo Tribunal Federal. Portanto, ainda que peculiar a hipótese, o cabimento do recurso ordinário em causas internacionais encontra amparo no texto constitucional, assim como nos princípios norteadores dos recursos." (SOUZA, 2007, p. 62).

${ }^{458}$ De forma incompreensível, a mesma doutrina que critica a previsão do recurso ordinário constitucional em ações constitucionais elogia a outorga de competência ao Superior Tribunal de Justiça para julgá-lo em causas internacionais:

"No Superior Tribunal de Justiça o recurso ordinário constitucional é previsto no art. 105, II, $a, b$ e $c$, da CF. Com referência a esse Tribunal, há particularidades que aconselham a manutenção de tal meio de impugnação.

Em primeiro lugar, será difícil uma questão veiculada em sede de recurso ordinário constitucional que não tenha correlação com a legislação infraconstitucional, apesar da possibilidade de serem debatidas leis municipais e estaduais ou mesmo constitucional. Na hipótese da alínea $c$ do permissivo constitucional que prevê o recurso ordinário, ficou evidenciada a preocupação do constituinte com a indicação de um Tribunal Superior para atuar como órgão de segunda instância quando um dos pólos da demanda estiver sendo ocupado por Estado estrangeiro ou organismo internacional e, de outro, município ou pessoa residente ou domiciliada no País. São situações excepcionais que merecem tratamento diferenciado." (GOMES JÚNIOR, 2003, pp. 478/479).

${ }^{459}$ ALEXANDRE FREITAS CÂMARA chega a dizer que, em causas internacionais, recurso ordinário constitucional e apelação são o mesmo instituto jurídico, alterando-se apenas o nome (2008, p. 113).
} 
representando qualquer demérito ou desrespeito ao ente estrangeiro a retirada dessa competência do Superior Tribunal de Justiça.

Tanto é assim que, em primeira instância, quem processa e julga a ação é um juiz federal, ainda que com um dia de magistratura, não sendo a "grande importância" da causa levada em consideração. Adotada a premissa do constituinte, lógico seria que o Tribunal Regional Federal fizesse as vezes de primeiro grau, passando à corte superior a competência recursal.

O julgamento de causas ou de recursos em causas em que é parte Estado estrangeiro ou organismo internacional não é função de tribunal superior. Não se garante o respeito ao ordenamento jurídico federal, constitucional ou infraconstitucional, não se zela pela harmonia entre os Poderes, nem se efetiva direitos fundamentais e liberdade individuais.

Tanto é assim, que nenhum tribunal superior europeu, seja na Itália, na França, em Portugal ou na Espanha, julga causas originariamente ou aprecia recurso ordinário em sentido amplo pelo simples fato de Estado estrangeiro ser parte.

A legislação argentina extrapola demais a competência da Corte Suprema por essa razão, chegando ao cúmulo de imputar a ela competência originária para processar e julgar causas em que é parte empregado doméstico de representante diplomático estrangeiro. $\mathrm{O}$ ordenamento jurídico uruguaio é muito mais comedido, outorgando competência à Suprema Corte de Justicia apenas quando o próprio representante diplomático estrangeiro for parte no processo.

Parece que esse é um ranço de colonialismo que os países latino-americanos conservam, sendo subservientes por demais aos estrangeiros, rebaixando o seu próprio Judiciário e os integrantes da sua magistratura, por não confiar a eles um processo ou um recurso idêntico a tantos outros que eles apreciam normalmente, pelo simples fato de determinada pessoa ser parte.

A história do recurso ordinário constitucional também revela que essa espécie recursal apenas passou a ser cabível em causas internacionais a partir da Constituição Federal de 1946, não tendo ligação tão forte com o recurso como as ações constitucionais.

O pequeno número de recursos ordinários constitucionais oriundos de causas internacionais julgados pelo Superior Tribunal de Justiça ${ }^{460}$ também não justifica a

\footnotetext{
${ }^{460}$ Em 2008 foram apenas 19 (dezenove) recursos, o mesmo número que 2009. Em 2010 foram 08 (oito) recursos. Foram distribuídos 13 (treze) recursos em 2011 e 11 (onze) em 2012. Em nenhum ano a distribuição do recurso ordinário constitucional em causas internacionais chegou a $0,01 \%$ (zero vírgula zero um por cento) do total 
manutenção dessa hipótese de cabimento, pois o que vale é a adequação da finalidade do recurso com as atribuições do tribunal superior, sendo incompatíveis neste caso.

Não bastasse, ainda se pode cogitar de inconstitucionalidade dessa hipótese de cabimento, pois trata de forma diversa União, Estados e Distrito Federal, de um lado, que quando litigam contra Estado estrangeiro ou organismo internacional têm o Supremo Tribunal Federal como juízo de primeiro e único grau (artigo 102, I, e, da Constituição Federal); e os Municípios, de outro, que têm juízo federal de primeiro grau como juízo a quo e o Superior Tribunal de Justiça como juízo ad quem, o que violaria o princípio federativo.

Portanto, entende-se que o recurso ordinário constitucional não deve ser cabível em causas internacionais, podendo as decisões proferidas nesses processos serem recorridas por meio dos demais recursos previstos no ordenamento jurídico pátrio (apelação, agravo etc.).

Essa conclusão também vale para embasar a exclusão da competência originária do Supremo Tribunal Federal para julgar os litígios em que a União, os Estados e/ou o Distrito Federal sejam parte, de um lado, e Estado estrangeiro ou organismo internacional sejam de outro.

\subsubsection{Crime político}

Por fim, no que se refere ao cabimento do recurso ordinário constitucional nos processos em que se apura a prática de crime político, considera-se que a previsão deve ser mantida tal como está.

Apesar de entendermos que o julgamento de recursos em processos que tratem de crime político não se enquadre perfeitamente em nenhuma das funções dos tribunais superiores, podendo apenas se aproximar da defesa de direitos fundamentais ${ }^{461}$, a justificativa para a manutenção dessa hipótese de cabimento do recurso ordinário constitucional é histórica e política.

Historicamente, o recurso ordinário constitucional é cabível em processos que versem sobre crime político apenas durante regimes democráticos após ditaduras, sendo previsto pela primeira vez pela Carta Magna de 1946, promulgada logo após o fim da Era Vargas, e retornando com a Constituição Federal de 1988, que surgiu após o fim da Ditadura Militar. É uma preocupação do constituinte originário, traumatizado com as atrocidades inerentes a

$<$ http://www.stj.jus.br/webstj/Processo/Boletim/?vPortalAreaPai=183\&vPortalArea=584>. Acesso em: 09 fev. 2013).

${ }^{461}$ Mas esse raciocínio também poderia levar à conclusão de que qualquer processo criminal envolve direito fundamental, podendo ser julgado por tribunal superior sem qualquer restrição. 
qualquer regime ditatorial, proteger a sociedade de novos abusos. Um dos meios de efetivar essa proteção é conceder aos órgãos máximos do Judiciário o poder-dever de julgar processos que digam respeito a crime político ${ }^{462}$.

A competência de tribunal de cúpula também previne o julgamento por vingança, pois faz com que o acusado seja julgado por colegiado amplo (onze Ministros, no caso brasileiro) e de altíssimo gabarito.

Argentina e Uruguai, países com história política e econômica parecida com a do Brasil, também concedem às suas cortes superiores competência para julgar processos que tratem de crime político, a primeira pela via recursal ordinária e o segundo por competência originária. Isso mostra que a escolha política brasileira não é isolada, encontrando respaldo em ordenamentos jurídicos estrangeiros.

É sim o Supremo Tribunal Federal o tribunal mais indicado para julgar essa hipótese de cabimento do recurso ordinário constitucional, pois é a corte de maior patente na hierarquia judiciária nacional; e não se pode reduzir as hipóteses de cabimento do recurso à decisão condenatória ou absolutória, pois o que justifica o cabimento dessa espécie recursal em crime político é a apuração desse fato, não sendo de grande relevância o resultado do julgamento pelo juízo a quo para que seja aberta a via recursal.

Dessa forma, em relação ao crime político, não se entende que deva haver qualquer modificação na atual previsão de cabimento do recurso ordinário constitucional.

\footnotetext{
${ }^{462}$ Conforme exposto na nota 170, Alcides DE MENDONÇA LiMA (1976, pp. 223/224) pondera que o recurso ordinário constitucional é cabível em casos de crime político porque estes "despertam paixões".
} 


\section{CONCLUSÃo}

1. O recurso ordinário constitucional é uma espécie recursal autônoma e heterogênea prevista no ordenamento jurídico brasileiro, sendo de competência exclusiva do Supremo Tribunal Federal e do Superior Tribunal de Justiça. Apesar de representar a garantia do duplo grau de jurisdição e de efetuar a isonomia em casos específicos e de grande relevância, ele é pouco estudado pelos processualistas e possui parca disciplina legal, o que contribui para o questionamento da sua autonomia e a má técnica processual na sua utilização prática.

2. O conceito de duplo grau de jurisdição não está positivado e foi definido pela doutrina. Duplo grau de jurisdição significa a possibilidade de dois juízos distintos, dotados de ampla cognição, proferirem decisões de mérito no mesmo processo, prevalecendo a segunda sobre a primeira.

3. A expressão "duplo grau de jurisdição" não traduz corretamente o instituto jurídico, pois não é necessário que haja diferença hierárquica entre os juízos que analisam a causa, excluindo-se o termo "grau", e porque não existem duas jurisdições no Brasil, afastando a palavra "jurisdição". Melhor utilizar a expressão “duplo juízo de cognição".

4. As vantagens de se adotar o duplo grau de jurisdição são: atender à necessidade psicológica do vencido de levar a sua tese a outro órgão julgador para que seja reexaminada, a diminuição da probabilidade de erro judicial, a maior experiência do segundo órgão julgador, a segunda decisão ser tomada de forma colegiada e a existência de um controle do mérito das decisões proferidas pelo Judiciário. Não são vantagens do duplo grau de jurisdição a uniformização da interpretação jurisprudencial e o maior cuidado do julgador de primeiro grau ao saber que a sua decisão pode passar por revisão.

5. A única desvantagem do duplo grau de jurisdição é aumentar o tempo de duração do processo. As demais desvantagens apontadas pela doutrina não o são de fato, pois não se pode considerar que o eventual desprestígio do primeiro grau possa vedar a existência de um segundo; mesmo quando a segunda decisão confirma a primeira há o benefício de diminuir o descontentamento do vencido; quando a segunda decisão altera a primeira corrige-se um erro e se efetiva a segurança jurídica, ainda que haja controvérsia na aplicação da lei naquele caso concreto; ainda que seja possível que o segundo órgão julgador erre, a probabilidade de erro é diminuída pelo reexame; e porque o princípio da oralidade já é bastante mitigado no Processo Civil moderno, sendo que a sua inobservância pelo duplo grau de jurisdição tende a diminuir pela adoção da tecnologia no processo. 
6. As vantagens do duplo grau de jurisdição superam sua desvantagem, pois é preferível que o processo seja justo e mais lento do que injusto e mais célere. Sopesando os valores celeridade e justiça, prefere-se prestigiar o segundo, sem que o primeiro seja negligenciado, já que se permite a realização do reexame completo da causa apenas uma segunda vez, não uma terceira, quarta, quinta.

7. O duplo grau de jurisdição é princípio constitucional implícito que decorre da previsão de tribunais na Constituição Federal. É mandamento de otimização, na clássica definição de ROBERT ALEXY, não regra, pois cede quando confrontado com outros princípios sem que seja eliminado do ordenamento jurídico, nem garantia, pois não se previu sua aplicação como forma ampla de defesa do cidadão contra o Estado.

8. Recurso, no direito brasileiro, é ato processual voluntário, a ser realizado em prazo peremptório pelas partes, por terceiros ou pelo Ministério Público na função de fiscal da lei, para possibilitar a reforma, anulação, integração ou esclarecimento de decisão judicial, no mesmo processo.

9. Duplo grau de jurisdição e recurso são institutos jurídico-processuais próximos, mas diferentes. Duplo grau de jurisdição nem sempre é voluntário, como ocorre com a remessa obrigatória, tampouco recurso permite o amplo reexame da causa pelo segundo julgador, ou mesmo sempre é dirigido a juízo diverso daquele que proferiu a decisão recorrida. Não obstante, os recursos são os principais meios de se efetivar o duplo grau de jurisdição.

10. Não se pode adotar a divisão de recursos entre "de fundamentação livre" ou "de fundamentação vinculada" como sinônimo de recursos "ordinários em sentido amplo" e "extraordinários em sentido amplo". O critério adotado pela a primeira classificação é a alegação que deve ser deduzida pelo recorrente para que o recurso possa ser conhecido, critério diverso daquele que separa os recursos em ordinários e extraordinários.

11. A classificação dos recursos entre ordinários e extraordinários é válida apenas para os recursos que exigem sucumbência como pressuposto recursal. O que os divide em uma ou outra categoria é a possibilidade de reexame da matéria de fato, já que ambas as categorias possibilitam novo julgamento sobre matéria de direito. Recurso ordinário em sentido amplo permite o reexame de fatos e de direito pelo juízo ad quem, enquanto recurso extraordinário em sentido amplo concede ao segundo julgador a permissão de reexaminar apenas direito.

12. Dizer que os recursos extraordinários têm a função precípua de tutelar o direito objetivo, enquanto os recursos ordinários tutelam principalmente o direito subjetivo, é critério 
impreciso, controvertido e falho para classificar os recursos. Sempre que tribunal superior julga recurso, qualquer recurso, influi diretamente no direito objetivo, ao criar precedente, vinculante ou não, que será aplicado pelo próprio tribunal e por outros tribunais nos julgamentos seguintes. O predomínio da tutela do direito objetivo é determinado pelo órgão julgador, não pelo recurso julgado, não sendo parâmetro válido para classificar as espécies recursais em ordinárias ou extraordinárias.

13. Historicamente, o recurso ordinário constitucional foi primeiro previsto pela Constituição Federal de 1891 e tinha como fundamentos a ausência de uma Justiça Federal organizada e o prestígio da defesa do direito fundamental de ir, vir e ficar, tutelado pelo habeas corpus. Atualmente, o primeiro fundamento não mais embasa a existência do recurso ordinário constitucional, mas a defesa de direitos fundamentais por meio desse recurso não só foi mantida, como ampliada.

14. A Constituição Federal de 1934 foi a primeira a denominar esse recurso de "recurso ordinário", sendo essa denominação seguida desde então. As Constituições Federais, emendas constitucionais e demais atos normativos com força normativa máxima (Ato Institucional $\left.n^{\circ} 02 / 1965\right)$ promulgados durante regimes ditatoriais restringiram as hipóteses de cabimento do recurso ordinário constitucional, em detrimento da defesa da sociedade. Já as Constituições Federais promulgadas na vigência de regimes democráticos reforçaram as hipóteses de cabimento dessa espécie recursal, conferindo maior tutela à sociedade em face do Estado.

15. A primeira lei ordinária a disciplinar o recurso ordinário constitucional foi a Lei $\mathrm{n}^{\mathrm{o}}$ 8.038/1990. Antes da vigência desse diploma legal, apenas o Regimento Interno do Supremo Tribunal Federal, e posteriormente também o do Superior Tribunal de Justiça, disciplinavam o recurso ordinário constitucional em nível infraconstitucional.

16. Nenhum Regimento Interno do Supremo Tribunal Federal denominou essa espécie recursal corretamente, confundindo-a com a apelação e mesmo criando figuras recursais inexistente, como o "recurso em habeas corpus". O Regimento Interno do Superior Tribunal de Justiça denomina recurso ordinário constitucional apenas aquele que é cabível em ações constitucionais, mas chama de "apelação" e de "agravo" aquele que pode ser interposto em causas internacionais.

17. A Lei $\mathrm{n}^{\circ} 8.038 / 1990$ era extremamente mal redigida, pois apenas utilizava o nome correto do recurso ordinário constitucional para discipliná-lo em ações constitucionais, também o chamando de "apelação" e "agravo" quando cabível em causas internacionais. Deixou de tratar do recurso ordinário constitucional em mandado de segurança de 
competência do Supremo Tribunal Federal, em mandado de injunção, em habeas data e em crime político. Foi substituída pela Lei $\mathrm{n}^{0}$ 8.950/1994, vigente até hoje, que reintroduziu a disciplina dos recursos destinados aos tribunais superiores no Código de Processo Civil, eliminou a confusão em relação ao nome do recurso e tratou de todas as hipóteses de cabimento dessa espécie recursal em Processo Civil.

18. As hipóteses de cabimento do recurso ordinário constitucional devem ser divididas com base no processo em que esse recurso pode ser interposto. Assim, separam-se em três as hipóteses de cabimento do recurso ordinário constitucional: em ações constitucionais (habeas corpus, mandado de segurança, habeas data e mandado de injunção), em causas internacionais (aquelas em que é parte, de um lado, Estado estrangeiro ou organismo internacional, e, de outro, Município ou pessoa residente ou domiciliada no Brasil), e processos que versem sobre a prática de crime político.

19. Em ações constitucionais, os requisitos gerais de cabimento do recurso ordinário constitucional são os seguintes: a decisão recorrida deve ser denegatória, colegiada, de instância final e proferida por tribunal.

20. Decisão denegatória é toda aquela que não concede o writ ao impetrante, julgando-lhe ou não o mérito.

21. Melhor dizer "acórdão" denegatório, de instância final e proferido por tribunal, já que esse é o termo utilizado para designar decisão colegiada. Não é cabível recurso ordinário constitucional contra decisão monocrática de relator, mas o recurso tem cabimento contra acórdão que julga agravo regimental que mantém o entendimento denegatório da decisão monocrática, ou que a reforma para denegar o writ.

22. Decisão de instância final é aquela que esgota os recursos ordinários em sentido amplo que podem ser interpostos. Embargos de declaração são recurso sui generis, não sendo necessária sua oposição para que o recurso ordinário constitucional possa ser conhecido.

23. Não é cabível recurso ordinário constitucional contra acórdão proferido por turma recursal, porque os Juizados Especiais não são “Tribunais Regionais Federais ou (...) tribunais dos Estados, do Distrito Federal e Territórios", conforme a letra do texto constitucional federal.

24. O recurso ordinário constitucional em habeas corpus, quando dirigido ao Superior Tribunal de Justiça, é cabível contra decisão de única ou última instância, sendo que nos demais casos de ações constitucionais é cabível apenas contra decisão de única instância. Isso revela a maior preocupação do constituinte em resguardar o direito fundamental de liberdade de locomoção, tutelado pelo habeas corpus. 
25. O recurso ordinário constitucional em mandado de segurança é cabível contra acórdão denegatório que julga o mandamus em única instância. Quando o tribunal competente é ordinário, o recurso é de competência do Superior Tribunal de Justiça, mas quando é tribunal superior quem julga o mandado de segurança originariamente, o recurso ordinário constitucional se dirige ao Supremo Tribunal Federal.

26. Apenas o Supremo Tribunal Federal possui competência para julgar recurso ordinário constitucional em habeas data e mandado de injunção, que podem ser interpostos contra acórdão denegatório proferido por tribunal superior que julgue essas ações constitucionais em única instância. O artigo 20, II, $b$, da Lei $\mathrm{n}^{\circ}$ 9.507/1997 que trata do procedimento do habeas data, deve ser interpretado como reiterativo do cabimento de recurso especial contra acórdão proferido por Tribunal Regional Federal em única instância que denega habeas data, pois não se pode ampliar a competência do Superior Tribunal de Justiça por norma infraconstitucional.

27. Nas causas internacionais, o recurso ordinário constitucional pode ser interposto contra decisão denegatória ou concessiva, final ou não, mas sempre será interposto contra decisão monocrática e de tribunal, porque a competência para o julgamento dessas ações em primeiro grau é de juiz federal. Ou seja, em causas internacionais há o recurso ordinário constitucional-apelação e o recurso ordinário constitucional-agravo, dependendo da decisão recorrida.

28. Em crime político, também não se verifica a necessidade da decisão recorrida ser denegatória, pois a razão para que o Supremo Tribunal Federal julgue recurso ordinário constitucional neste caso é política, sendo importante verificar a ocorrência ou não do crime.

29. Os requisitos de admissibilidade do recurso ordinário constitucional são os gerais aplicáveis aos recursos. O prazo para interposição desse tipo de recurso é de 15 (quinze) dias, com exceção daqueles interpostos contra decisões interlocutórias em causas internacionais, que é de 10 (dez) dias, pois não se pode tratar desigualmente as partes apenas porque se trata de causa internacional.

30. Não é possível aplicar o princípio da fungibilidade recursal e receber como recurso ordinário constitucional o recurso extraordinário ou o recurso especial interposto contra a parte denegatória de acórdão que julga ação constitucional. Também não se pode receber como recurso extraordinário ou recurso especial o recurso ordinário constitucional interposto contra a parte concessiva do acórdão. Por outro lado, deve ser aplicado o princípio da fungibilidade recursal se for interposta apelação no lugar de recurso ordinário constitucional, em causas internacionais. 
31. O efeito devolutivo do recurso ordinário constitucional é amplo, sendo admitida a rediscussão de matéria de fato, de cláusula contratual, de direito local, federal infraconstitucional e federal constitucional em todas as hipóteses. Aplica-se a teoria da causa madura ao recurso ordinário constitucional, pois não há usurpação de competência de tribunal, superior ou não, porque há norma jurídica que autoriza a aplicação dessa teoria por analogia, bem como se efetiva a garantia constitucional da duração razoável do processo.

32. Nas ações constitucionais, o recurso ordinário constitucional não é dotado de efeito suspensivo, em razão da natureza da causa julgada, não de particularidade da espécie recursal, podendo ser concedido esse efeito por meio do ajuizamento de cautelar incidental ou requerimento de antecipação dos efeitos da tutela recursal. Nas causas internacionais, quando interposto contra sentença, segue a mesma regra da apelação, por analogia, sendo dotado de suspensividade, com exceção das hipóteses previstas nos incisos do artigo 520 do Código de Processo Civil; e quando interposto contra decisão interlocutória, segue a regra do recurso de agravo.

33. O recurso ordinário constitucional passa por duplo exame de admissibilidade, com exceção dos casos em que é interposto contra decisão interlocutória e na forma de instrumento, em causas internacionais. É possível a aplicação do disposto no artigo 518, $\S 1^{\circ}$, do Código de Processo Civil (“súmula impeditiva de recursos”).

34. É competente para realizar o exame de admissibilidade do recurso, no juízo a quo, o relator que presidiu a instrução e o julgamento da ação constitucional ou o juiz federal que processou e julgou a causa internacional, em razão da norma expressa do artigo 540 do Código de Processo Civil, não sendo possível alterar essa regra por disposição de regimento interno de tribunal.

35. O recurso cabível contra a decisão do juízo a quo que não admite recurso ordinário constitucional é o agravo de instrumento, também em decorrência da norma expressa do artigo 540 do Código de Processo Civil. Todavia, deve-se aplicar o princípio da fungibilidade recursal, recebendo agravo regimental ou agravo na forma do artigo 544 do Código de Processo Civil, tendo em vista que há normas e entendimentos doutrinários e jurisprudenciais divergentes neste ponto.

36. O procedimento no juízo ad quem aplicável ao recurso ordinário constitucional difere do aplicável ao recurso de apelação apenas em dois pontos: não há revisor e o quórum mínimo de votação desse recurso é de 05 (cinco) magistrados. Quando interpostos recurso ordinário constitucional e recurso extraordinário ou recurso especial no mesmo processo, eles 
são julgados em conjunto, sendo a competência do Pleno do Supremo Tribunal Federal quando este for o tribunal competente.

37. Não é possível a interposição de recurso ordinário constitucional adesivo em nenhuma hipótese de cabimento. Em ações constitucionais, não há recurso principal da mesma espécie ao qual se possa aderir, já que o recurso ordinário constitucional apenas pode ser interposto contra a parte denegatória da decisão. O mesmo vale em relação a recurso extraordinário ou recurso especial adesivo a recurso ordinário constitucional. Em causas internacionais, a adesão não é possível porque o artigo 500, II, do Código de Processo Civil foi alterado pela Lei $\mathrm{n}^{\mathrm{o}} 8.950 / 1994$, que, ao não prever o cabimento de recurso ordinário constitucional na forma adesiva, revelou o silêncio eloquente do legislador.

38. Embargos infringentes não são cabíveis em recurso ordinário constitucional, por expressa vedação legal do artigo 25 da Lei $\mathrm{n}^{\mathrm{o}}$ 12.016/2009, que trata do mandado de segurança, e porque o artigo 530 do Código de Processo Civil foi reformado pela Lei $\mathrm{n}^{\circ}$ 10.352/2001 com a intenção de restringir o cabimento dos embargos infringentes, não sendo possível a aplicação de analogia neste caso, por violar o espírito da lei.

39. Embargos de divergência não podem ser opostos em sede de recurso ordinário constitucional. A lei é clara ao definir as hipóteses de cabimento de embargos de divergência: apenas contra acórdãos que julguem recurso extraordinário ou recurso especial. Não há margem para interpretação ampliativa nesse caso, até porque a analogia não é cabível, dado que o recurso ordinário constitucional é um recurso ordinário em sentido amplo e os recursos extraordinário e especial são extraordinários em sentido amplo. Por outro lado, é possível que acórdão que julgou recurso ordinário constitucional sirva de paradigma para a oposição de embargos de divergência.

40. O Supremo Tribunal Federal é o órgão de maior hierarquia na estrutura judiciária brasileira. Sua função precípua é guardar a Constituição Federal, mas, por fazer parte do Poder Judiciário e por ser dotado de competência originária e recursal ordinária para casos que não têm relação com a proteção à Carta Magna, não pode ser considerado uma corte constitucional de forma clássica.

41. Em razão da crise pela qual passava o Supremo Tribunal Federal, com grande número de processos distribuídos a essa corte, a Constituição Federal de 1988 criou o Superior Tribunal de Justiça, responsável por zelar pela inteireza das normas federais infraconstitucionais, função anteriormente atribuída ao Pretório Excelso.

42. As funções comuns a esses tribunais superiores são: a proteção das normas federais, constitucionais, no caso do Supremo Tribunal Federal, e infraconstitucionais, no 
caso do Superior Tribunal de Justiça, o que pode ser feito por meio da pacificação da interpretação jurisprudencial dessas normas e da criação de precedentes, vinculantes ou não; assegurar a harmonia entre os Poderes; e respeitar os direitos fundamentais; destacando-se a primeira e a última.

43. Os tribunais de sobreposição da Itália e da França não possuem competência originária ou recursal ordinária para reexaminar fatos, e não há nenhum processo ou recurso de sua competência que se assemelhe ao recurso ordinário constitucional brasileiro.

44. Portugal já previu o cabimento de um recurso ordinário em sentido amplo contra as decisões dos magistrados integrantes de tribunais, a sopricação ou agravo ordinário, revogado em 1832. Atualmente, o Supremo Tribunal de Justiça português possui competência similar à competência recursal ordinária dos tribunais superiores brasileiros apenas no que se refere ao julgamento de habeas corpus e de revisões criminais.

45. A Espanha atribui ao seu Tribunal Constitucional a competência para julgar recurso de amparo, instrumento processual análogo ao mandado de segurança, no que se assemelha mais à previsão normativa brasileira em relação ao cabimento de recurso ordinário constitucional.

46. A competência da Corte Suprema da Argentina é bastante mais similar à competência dos tribunais de sobreposição do Brasil. Aquele tribunal é competente para julgar casos envolvendo Estado estrangeiro, diplomata estrangeiro (e também seus familiares e empregados domésticos) e até mesmo cidadão estrangeiro (apenas quando litiga em face de Província argentina) e para julgar recursos em processos que apurem a prática de crime político. Porém, a semelhança com a proteção aos direitos fundamentais pelo recurso ordinário constitucional brasileiro é menor, pois a Corte Suprema apenas julga recursos em processos criminais em que houve condenação superior a 10 (dez) anos de prisão.

47. A Suprema Corte de Justicia do Uruguai também é competente para julgar processos em que é parte diplomata estrangeiro, processos que tratem de crimes contra os direitos fundamentais (incluindo-se aí os crimes políticos) e tutela os direitos fundamentais ao atribuir competência para o seu tribunal superior analisar a consulta, mecanismo processual similar ao reexame necessário brasileiro, em casos criminais.

48. Ordenamentos jurídicos estrangeiros preveem competência originária ou recursal ordinária para que seus tribunais superiores julguem casos análogos àqueles apreciados pela via do recurso ordinário constitucional. Esses casos têm ligação com a defesa de direitos fundamentais (Portugal, Espanha, Argentina e Uruguai), com a verificação da prática de crime 
político (Argentina e Uruguai) e com o respeito à soberania de Estados estrangeiros (Argentina e Uruguai).

49. O recurso ordinário constitucional deve permanecer sendo cabível em ações constitucionais, pois a proteção de direitos fundamentais é uma das funções dos tribunais superiores; há ordenamentos jurídicos estrangeiros, como o português, o espanhol, o argentino e o uruguaio, que também atribuem competência para suas cortes superiores julgarem matéria de fato para a proteção de direitos fundamentais; historicamente, essa espécie recursal sempre esteve ligada à defesa de direitos fundamentais, já fazendo parte da cultura processual brasileira; o seu julgamento não prejudica o regular funcionamento dos tribunais superiores, por representar percentual reduzido de processos distribuídos; e porque ele não viola, mas sim efetiva a igualdade material entre litigantes.

50. Deve ser reduzido o cabimento de recurso ordinário constitucional dirigido ao Superior Tribunal de Justiça em habeas corpus, apenas para decisão de única instância. Não é necessária a criação de terceiro grau julgador e não se pode prestigiar apenas um direito fundamental, o de liberdade de locomoção, em detrimento dos demais, tuteláveis pelas outras ações constitucionais.

51. O cabimento de recurso ordinário constitucional em mandado de segurança deve ser mantido tal como está, porque efetiva o duplo grau de jurisdição apenas em processos de competência originária de tribunais.

52. Da mesma forma, não se pode ampliar ou reduzir os casos em que é cabível esse recurso em mandado de injunção, pois ao conceder ao Superior Tribunal de Justiça competência para julgar recurso ordinário constitucional interposto em mandado de injunção julgado por Tribunal de Justiça dos Estados ou do Distrito Federal e Territórios estar-se-ia atribuindo a ele apenas o poder-dever de examinar direito local, quebrando o princípio federativo.

53. Deve-se permitir a interposição de recurso ordinário constitucional, destinado ao Superior Tribunal de Justiça, contra acórdão proferido por Tribunal Regional Federal em julgamento de única instância de habeas data. Somente neste caso específico, direito federal analisado por essa ação constitucional não está sujeito ao duplo grau de jurisdição, o que fere a igualdade.

54. Para se realizar qualquer das modificações acima mencionadas, é necessária a reforma da Constituição Federal, não sendo possível que norma infraconstitucional amplie ou reduza a competência de tribunal superior, tampouco se pode alterar a interpretação do texto normativo para permitir ou vedar esse cabimento. 
55. Deve-se abolir o recurso ordinário constitucional em causas internacionais. Essa modalidade se assemelha muito à apelação e ao agravo, sendo plenamente possível o emprego desses recursos para se atingir os mesmos fins que o recurso ordinário constitucional neste caso, em que a única diferença em relação aos demais processos são as partes. Os Tribunais Regionais Federais poderiam julgar recursos nesses casos sem qualquer demérito ao Estado estrangeiro ou ao organismo internacional, já que não é função de tribunal superior esse julgamento. A previsão de recursos análogos nos ordenamento jurídicos argentino e uruguaio não é suficiente para a manutenção dessa hipótese de cabimento, pois apenas revela o espírito colonialista e subserviente dos países latino-americanos, que parecem desconfiar dos seus próprios Judiciários. Não há grande ligação histórica entre o recurso ordinário constitucional e as causas internacionais, sendo possível inclusive questionar a constitucionalidade dessa norma, que trata diferentemente os Municípios, quando em comparação com a União, os Estados e o Distrito Federal.

56. O cabimento do recurso ordinário constitucional em processos que versem sobre crime político deve ser integralmente mantido. O que justifica essa hipótese de cabimento são fatores históricos e políticos, sendo imprescindível que nações que passaram por regimes ditatoriais e voltaram à democracia apurem com total isenção a prática desses delitos. Não importa o resultado do julgamento anterior, mas sim a imputação de crime político àlguém. 


\section{REFERÊNCIAS}

ABDO, Helena Najjar. Embargos de divergência: aspectos históricos, procedimentais, polêmicos e de direito comparado. NERY JR., Nelson; WAMBIER, Teresa Arruda Alvim (coords.). Aspectos polêmicos e atuais dos recursos cíveis e assuntos afins - v. 9. São Paulo: Revista dos Tribunais, 2006.

ALEXY, Robert. Teoria dos direitos fundamentais. Tradução de Virgílio Afonso da Silva. São Paulo: Malheiros, 2008.

AMARAL SANTOS, Moacyr. Primeiras linhas de direito processual civil - v. 3. 24. ed. São Paulo: Saraiva, 2010.

AMENDOEIRA JR., Sidnei. Manual de direito processual civil - v. 2. São Paulo: Saraiva, 2012.

AMERICANO, Luiz Alberto. Do recurso ordinário constitucional em matéria civil. Revista dos Tribunais, São Paulo, v. 362, p. 69-77, dez. 1965.

AMORIM, Aderbal Torres de. Recursos cíveis ordinários. Porto Alegre: Livraria do Advogado Ed., 2005.

ASSIS, Araken de. Manual dos recursos. 3. ed. São Paulo: Revista dos Tribunais, 2011.

- Recurso ordinário. ASSIS, Araken de; MADEIRA, Luís Gustavo Andrade (coords.). Direito processual civil - as reformas e questões atuais do direito processual civil. Porto Alegre: Livraria do Advogado Ed., 2008.

BANDEIRA DE MELLO, Celso Antônio. Curso de direito administrativo. 29. ed. São Paulo: Malheiros, 2012.

BARBI, Celso Agrícola. O recurso ordinário em mandado de segurança no Superior Tribunal de Justiça. TEIXEIRA, Sálvio de Figueiredo (coord.). Recursos no Superior Tribunal de Justiça. São Paulo: Saraiva, 1991. 
BARBOSA, José Túlio. Do mandado de segurança e do efeito suspensivo do recurso ordinário. Revista dos Tribunais, v. 661, p. 51-65, nov. 1990.

BARBOSA MOREIRA, José Carlos. Comentários ao Código de Processo Civil - v. V. 15. ed. Rio de Janeiro: Forense, 2010.

. O juizo de admissibilidade no sistema dos recursos. Rio de Janeiro:

Forense, 1968.

. O novo processo civil brasileiro. 29. ed. Rio de Janeiro: Forense, 2012.

. La igualdad de las partes en el proceso civil. Revista de Processo, São Paulo, n. 44, p. 176-185, out-dez. 1986.

Temas de direito processual (sétima série). São Paulo: Saraiva, 2001.

BECKER, Laércio. Duplo grau - A retórica de um dogma. MARINONI, Luiz Guilherme (coord.). Estudos de direito processual civil: homenagem ao Professor Egas Dirceu Moniz de Aragão. São Paulo: Revista dos Tribunais, 2005.

BEDAQUE, José Roberto dos Santos. Direito e processo - influência do direito material sobre o processo. 6. ed. São Paulo: Malheiros, 2011.

BERMUDES, Sérgio. As reformas do Código de Processo Civil. 3. ed. São Paulo: Saraiva, 2010.

. Comentários ao Código de Processo Civil - vol. 7. São Paulo: Revista dos Tribunais, 1975.

BONAVIDES, Paulo. Curso de direito constitucional. 27. ed. São Paulo: Malheiros, 2012.

BORÉ, Jacques. La cassation em matière civile. Paris: Sirey, 1980.

BOTELHO DE MESQUITA, José Ignácio. Teses, estudos e pareceres de processo civil -v. 2. São Paulo: Revista dos Tribunais, 2005. 
BUENO, Cássio Scarpinella. Curso sistematizado de direito processual civil: Teoria geral do direito processual civil. 6. ed. São Paulo: Saraiva, 2012.

. Curso sistematizado de direito processual civil: Recursos. Processos e incidentes nos tribunais. Sucedâneos recursais: técnicas de controle das decisões judiciais. 3. ed. São Paulo: Saraiva, 2011.

. Efeitos dos recursos. NERY JR., Nelson; WAMBIER, Teresa Arruda Alvim (coords.). Aspectos polêmicos e atuais dos recursos cíveis e assuntos afins - v. 10. São Paulo: Revista dos Tribunais, 2006.

CALAMANDREI, Piero. La casación civil - tomo I, v. 2. Buenos Aires: Editorial Bibliografica Argentina, 1945.

CALMON DE PASSOS, J. J. O devido processo e o duplo grau de jurisdição. Revista Forense, Rio de Janeiro, v. 277, p. 01-07, jan.-mar. 1982.

CANOtilho, J. J. Gomes. Direito constitucional e teoria da Constituição. 5. ed. Coimbra: Almedina, 2001.

CARNEIRO, Athos Gusmão. Os embargos de declaração e a súmula 281 do Supremo Tribunal Federal. YARSHELL, Flávio Luiz; MORAES, Maurício Zanoide de (orgs.). Estudos em homenagem à Professora Ada Pellegrini Grinover. São Paulo: DPJ Editora, 2005.

CARREIRA ALVIM, José Eduardo. Comentários ao Código de Processo Civil brasileiro - v. 7. Curitiba: Juruá, 2011.

CARTAXO, Ernani Guarita. O recurso ordinário no mandado de segurança. Revista dos Tribunais, São Paulo, v. 298, p. 773-774, ago. 1960.

CARVALHO, Milton Paulo de. Princípios gerais do direito processual civil. CARVALHO, Milton Paulo de (coord.). Teoria geral do processo civil. Rio de Janeiro: Elsevier, 2010.

CHEIM JORGE, Flávio. Embargos de divergência: alguns aspectos estruturantes. Revista de Processo, São Paulo, n. 190, p. 09-36, dez. 2010. 
- Teoria geral dos recursos cíveis. 5. ed. São Paulo: Revista dos Tribunais, 2011.

CINTRA, Antonio Carlos de Araújo; GRINOVER, Ada Pellegrini; DINAMARCO, Cândido Rangel. Teoria geral do processo. 22. ed. São Paulo: Malheiros, 2006.

COMOGLIO, Luigi Paolo. Garanzie costituzionale e 'giusto processo' (modelli a confronto). Revista de Processo, São Paulo, n. 90, p. 95-150, abr.-jun. 1998.

. I modelli di garanzia costituzionale del processo. Rivista Trimestrale di Diritto e Procedura Civile, Milano, n. 3, p. 673-741, 1991.

. Il doppio grado di giudizio nelle prospettive di revisione costituzionale. Rivista de Diritto Processuale, Padova, v. 54, p. 317-334, 1999.

COUTURE, Eduardo J. Fundamentos del derecho procesal civil. 3. ed. Buenos Aires: Roque Depalma Editor, 1958.

CRUZ E TUCCI, José Rogério. Garantias constitucionais da duração razoável e da economia processual no projeto do Código de Processo Civil. Revista de Processo, São Paulo, n. 192, p. 193-209, fev. 2011.

CRUZ E TUCCI, José Rogério; AZEVEDO, Luiz Carlos de. Lições de história do processo civil lusitano. São Paulo: Revista dos Tribunais, 2009.

DELGADO, José Augusto. Aspectos gerais dos embargos de divergência: origem, conceito, pressupostos e controvérsias. FÉRES, Marcelo Andrade; CARVALHO, Paulo Gustavo M. (coords.). Processo nos tribunais superiores. São Paulo: Saraiva, 2006.

DIDIER JR., Fredie; CUNHA, Leonardo José Carneiro da. Curso de direito processual civil: meios de impugnação às decisões judiciais e processo nos tribunais. 8. ed. Salvador: JusPODIVM, 2010.

DINAMARCO, Cândido Rangel. A reforma do Código de Processo Civil. São Paulo: Malheiros, 1995. 
. Fundamentos do processo civil moderno - v. I. 6. ed. São Paulo: Malheiros, 2010.

. Instituições de direito processual civil - v. I. 5. ed. São Paulo: Malheiros, 2005.

. Nova era do processo civil. 3. ed. São Paulo: Malheiros, 2009.

. Vocabulário do processo civil. São Paulo: Malheiros, 2009.

ELIAS, Carlos Eduardo Stefen. Os fundamentos da estrutura do sistema recursal no Código de Processo Civil de 1973 e no projeto de novo Código de Processo Civil. NERY JR., Nelson; WAMBIER, Teresa Arruda Alvim (coords.). Aspectos polêmicos e atuais dos recursos cíveis e assuntos afins - v. 12. São Paulo: Revista dos Tribunais, 2011.

EVANGELISTA, Samoel Martins; SOUZA, Celso Jerônimo de. Efeitos do recurso ordinário cível. Congresso Nacional do Ministério Público (16: 2005: Belo Horizonte, MG). Ministério Público e justiça social em defesa da ética e dos direitos fundamentais. Brasília: Associação Nacional dos Membros do Ministério Público, 2005, pp. 589/600.

FAZZALARI, Elio. Il giudizio civile di cassazione. Milano: Giuffré, 1960.

FÉRES, Marcelo Andrade. Dos embargos de divergência no âmbito do STF. FÉRES, Marcelo Andrade; CARVALHO, Paulo Gustavo M. (coords.). Processo nos tribunais superiores. São Paulo: Saraiva, 2006.

FERNÁNDEZ, Sergi Guasch. El hecho e el derecho em la casación civil. Barcelona: José María Bosch Editor, 1998.

FERREIRA, Fernando Amâncio. Manual dos recursos em processo civil. Coimbra: Almedina, 2000.

FONSECA, João Francisco Naves da. Exame dos fatos nos recursos extraordinário e especial. São Paulo: Saraiva, 2012.

FRANCO, Fernão Borba. Vicissitudes do duplo grau de jurisdição: o art. 515, $\S 3 .^{\circ}$, do CPC. MEDINA, José Miguel Garcia et al (coords.). Os poderes do juiz e o controle das 
decisões judiciais - Estudos em homenagem à Professora Teresa Arruda Alvim Wambier. São Paulo: Revista dos Tribunais, 2008.

FREIRE, Rodrigo da Cunha Lima. Reflexões sobre o cabimento dos embargos de divergência em recurso especial. ASSIS, Araken de et al (coords.). Direito civil e processo Estudos em homenagem ao Professor Arruda Alvim. São Paulo: Revista dos Tribunais, 2008.

FREITAS CÂMARA, Alexandre. Lições de direito processual civil - v. II. 15. ed. Rio de Janeiro: Lumen Juris, 2008.

FUX, Luiz. Curso de direito processual civil - v. I. 4. ed. Rio de Janeiro: Forense, 2008 .

GODINHO, Robson Renault. Direito constitucional ao recurso. THEODORO JÚNIOR, Humberto; CALMON, Petrônio; NUNES, Dierle (coords.). Processo e Constituição: os dilemas do processo constitucional e dos princípios processuais constitucionais. Rio de Janeiro: GZ Editora, 2011.

GOMES JÚNIOR, Luiz Manoel. Recurso ordinário constitucional - considerações relevantes. NERY JR., Nelson; WAMBIER, Teresa Arruda Alvim (coords.). Aspectos polêmicos e atuais dos recursos cíveis e de outros meios de impugnação às decisões judiciais. São Paulo: Revista dos Tribunais, 2003.

GONÇALVES, Marcus Vinícius Rios. Novo curso de direito processual civil 1. 9. ed. São Paulo: Saraiva, 2012.

Novo curso de direito processual civil 2. 8. ed. São Paulo: Saraiva, 2012.

GONÇALVES, Tiago Figueiredo. Do cabimento de recursos ordinários e especial contra acórdão proferido por turma recursal nos Juizados Especiais. NERY JR., Nelson; WAMBIER, Teresa Arruda Alvim (coords.). Aspectos polêmicos e atuais dos recursos cíveis e assuntos afins - v. 10. São Paulo: Revista dos Tribunais, 2006.

GRANADO, Daniel Willian. São admissíveis embargos de divergência quando o acórdão paradigma não provém de recurso especial? - Análise da orientação do STJ. Revista de Processo, São Paulo, n. 186, p. 270-298, ago. 2010. 
GRECO FILHO, Vicente. Direito processual civil brasileiro - v. 1. 22. ed. São Paulo: Saraiva, 2010.

$$
\text { . Direito processual civil brasileiro - v. 2. 21. ed. São Paulo: Saraiva, }
$$

2012.

HOFFMAN, Paulo. Razoável duração do processo. São Paulo: Quartier Latin, 2006.

JAUFFRET, Alfred; NORMAND, Jacques. Manuel de procédure civile et voies d'exécution. 14. ed. Paris: Librairie Générale de Droit et de Jurisprudence, 1984.

KOZIKOSKI, Sandro Marcelo. Manual dos recursos cíveis - Teoria geral e recursos em espécie. 4. ed. Curitiba: Juruá, 2011.

KUKINA, Sérgio Luiz. O princípio do duplo grau de jurisdição. Revista de Processo, São Paulo, n. 109, p. 97-112, jan.-mar. 2003.

LACOMBE, Arnaldo Cavalcanti. Efeito suspensivo do recurso ordinário de mandado de segurança. Revista Forense, Rio de Janeiro, v. 173, p. 495-502, set.-out. 1957.

LASPRO, Oreste Nestor de Souza. Duplo grau de jurisdição no direito processual civil. São Paulo: Revista dos Tribunais, 1995.

. Garantia do duplo grau de jurisdição. CRUZ E TUCCI, José Rogério (coord.). Garantias constitucionais do processo civil: homenagem aos 10 anos da Constituição Federal de 1988. São Paulo: Revista dos Tribunais, 1999.

O objeto dos embargos de divergência. Revista de Processo, São Paulo, n. 186, p. 09-30, ago. 2010.

LEAL, Paulo J. B.; PORTO ALEGRE, Valdir. Duplo grau de jurisdição. Revista dos Tribunais, São Paulo, v. 826, p. 727-739, ago. 2004.

LEONEL, Ricardo de Barros. Cognição judicial em grau de apelação, à luz das reformas do CPC. Justitia, São Paulo, v. 197, p. 199-210, jul.-dez. 2007. 
Revisitando a teoria geral dos recursos: o efeito suspensivo. NERY JR., Nelson; WAMBIER, Teresa Arruda Alvim (coords.). Aspectos polêmicos e atuais dos recursos cíveis e assuntos afins - v. 9. São Paulo: Revista dos Tribunais, 2006.

LEYSER, Maria Fátima Vaquero Ramalho. O sistema recursal no mandado de segurança. ARRUDA ALVIM, Eduardo Pellegrini de; NERY JR., Nelson; WAMBIER, Teresa Arruda Alvim. Aspectos polêmicos e atuais dos recursos. São Paulo: Revista dos Tribunais, 2000.

LIMA, Getúlio Targino. Apontamentos sobre o recurso ordinário constitucional. 2. ed. São Paulo: Juarez de Oliveira, 2007.

LIMA, José Edvaldo Albuquerque. Recursos ordinários, extraordinários e especial. Leme: Mundo Jurídico, 2008.

LINS, Rodrigo Martiniano Ayres. A relativização do princípio do duplo grau cognitivo no processo civil brasileiro como instrumento de efetividade da tutela jurisdicional. Revista Forense, Rio de Janeiro, v. 385, p. 173-184, mai.-jun. 2006.

LOPES, Fátima Cristina. O art. 515, § 3. ${ }^{\circ}$, do CPC e o duplo grau de jurisdição. Revista de Processo, São Paulo, n. 170, p. 161-179, abr. 2009.

LUCON, Paulo Henrique dos Santos. Art. 515, § 3. ${ }^{\circ}$, do Código de Processo Civil, ordem pública e prequestionamento. MEDINA, José Miguel Garcia et al (coords.). Os poderes do juiz e o controle das decisões judiciais - Estudos em homenagem à Professora Teresa Arruda Alvim Wambier. São Paulo: Revista dos Tribunais, 2008.

MACHADO, Denise Maria Weiss de Paula; LEAL JÚNIOR, João Carlos. Análise crítica do duplo grau de jurisdição sob o prisma do direito à razoável duração do processo. Revista de Processo, São Paulo, n. 183, p. 77-118, mai. 2010.

MANCUSO, Rodolfo de Camargo. Recurso extraordinário e recurso especial. 12. ed. São Paulo: Revista dos Tribunais, 2013.

MANDRIOLI, Crisanto. Corso di diritto processuale civile - v. 2. Torino: G. Giappichelli, 2000. 
MARCACINI, Augusto Tavares Rosa. Assistência jurídica, assistência judiciária e justiça gratuita. Rio de Janeiro: Forense, 1996.

MARCATO, Ana Cândida Menezes. O princípio do duplo grau de jurisdição e a reforma do Código de Processo Civil. São Paulo: Atlas, 2006.

MARINONI, Luiz Guilherme; ARENHART, Sérgio Cruz. Processo de conhecimento. 10. ed. São Paulo: Revista dos Tribunais, 2011.

MARQUES, José Frederico. Instituições de direito processual civil - v. IV. Campinas: Millennium, 2000.

MAZZARELLA, Fernando. Analisi del giudizio civile di cassazione. Pádua: Cedam, 1994.

MEDINA, José Miguel Garcia; WAMBIER, Teresa Arruda Alvim. Recursos e ações autônomas de impugnação. São Paulo: Revista dos Tribunais, 2008.

MELO, Ricardo Procópio Bandeira de. Princípio do duplo grau de jurisdição: garantia constitucional, extensão e algumas notas sobre o $\S 3 .^{\circ}$ do art. 515 do CPC. NERY JR., Nelson; WAMBIER, Teresa Arruda Alvim (coords.). Aspectos polêmicos e atuais dos recursos cíveis e de outros meios de impugnação às decisões judiciais - v. 8. São Paulo: Revista dos Tribunais, 2005.

MELLO, Marco Aurélio. Considerações acerca da competência originária e recursal do Supremo Tribunal Federal. BONAVIDES, Paulo; MORAES, Germana; ROSAS, Roberto (orgs.). Estudos de direito constitucional em homenagem a Cesar Asfor Rocha (teoria da Constituição, direitos fundamentais e jurisdição). Rio de Janeiro: Renovar, 2009.

MENDES, Claudia Brodt; RAGAZZI, José Luiz. Constitucionalidade da supressão do duplo grau de jurisdição - artigo $515 \S 3^{\circ}$ do CPC. Revista do Instituto de Pesquisas e Estudos, Bauru, v. 41, n. 48, p. 325-336, jul.-dez. 2007.

MENDES, Gilmar Ferreira; BRANCO, Paulo Gustavo Gonet. Curso de direito constitucional. 6. ed. São Paulo: Saraiva, 2011. 
MENDES, Leonardo Castanho. O recurso especial e o controle difuso de constitucionalidade. São Paulo: Revista dos Tribunais, 2006.

MENDONÇA, Grace Maria Fernandes. O recurso ordinário no Supremo Tribunal Federal. FÉRES, Marcelo Andrade; CARVALHO, Paulo Gustavo M. (coords.). Processo nos tribunais superiores. São Paulo: Saraiva, 2006.

MENDONÇA LIMA, Alcides de. Introdução aos recursos cíveis. 2. ed. São Paulo: Revista dos Tribunais, 1976.

. O recurso ordinário constitucional. Revista Forense, v. 177, p. 54-60, mai.-jun. 1958.

MIRABETE, Julio Fabbrini; FABBRINI, Renato N. Manual de direito penal - v. I. 26. ed. São Paulo: Atlas, 2010.

MIRANDA, Gilson Delgado; PIZZOL, Patricia Miranda. Recursos no processo civil. 6. ed. São Paulo: Atlas, 2009.

MORAES, Alexandre de. Direito constitucional. 27. ed. São Paulo: Atlas, 2011.

NEGRÃO, Theotonio; GOUVÊA, José Roberto F. Código de Processo Civil e legislação processual em vigor. 41. ed. São Paulo: Saraiva, 2009.

NEGRÃO, Theotonio et al. Código de Processo Civil e legislação processual em vigor. 44. ed. São Paulo: Saraiva, 2012.

NERY JÚNIOR, Nelson. Princípios do processo na Constituição Federal. 10. ed. São Paulo: Revista dos Tribunais, 2010.

. Teoria geral dos recursos. 6. ed. São Paulo: Revista dos Tribunais, 2004.

NERY JÚNIOR, Nelson; NERY, Rosa Maria de Andrade. Constituição Federal comentada e legislação constitucional. 2. ed. São Paulo: Revista dos Tribunais, 2009.

. Código de Processo Civil comentado e legislação extravagante. 12. ed. São Paulo: Revista dos Tribunais, 2012. 
NEVES, Daniel Amorim Assumpção. Manual de direito processual civil: volume único. 3. ed. São Paulo: Método, 2011.

NOGUEIRA, Maurício José. Duplo grau de jurisdição: aspectos constitucionais e reflexos processuais. FUX, Luiz; NERY JR. Nelson; WAMBIER, Teresa Arruda Alvim (coords.). Processo e Constituição: estudos em homenagem ao Professor José Carlos Barbosa Moreira. São Paulo: Revista dos Tribunais, 2006.

OLIVEIRA, Bruno Silveira de. O duplo grau de jurisdição: princípio constitucional?. Revista de Processo, São Paulo, n. 162, p. 362-382, ago. 2008.

ORIONE NETO, Luiz. Recursos cíveis. 3. ed. São Paulo: Saraiva, 2009.

PASSOS, Paulo Roberto. Algumas reflexões sobre o duplo grau de jurisdição. Revista de Processo, n. 69, São Paulo, p. 155-159, jan.-mar., 1993.

PONTES DE MIRANDA, Francisco Cavalcanti. Comentários ao Código de Processo Civil - tomo VIII. Rio de Janeiro: Forense, 1975.

REDENTI, Enrico. Diritto processuale civile - v. 2. 4. ed. Milano: Giuffrè, 1997.

RODRIGUES, Maria Stella Villela Souto Lopes. Recursos na novo Constituição: extraordinário, especial e ordinário constitucional em mandado de segurança e habeas corpus e as ações penais originárias. 3. ed. São Paulo: Revista dos Tribunais, 1997.

ROENICK, Hermann Homem de Carvalho. Recursos no CPC. Rio de Janeiro: AIDE Editora, 1999.

SÁ, Djanira Maria Radamés de. Duplo grau de jurisdição: conteúdo e alcance constitucional. São Paulo: Saraiva, 1999.

SANTOS, Cláudio. Competência do Superior Tribunal de Justiça; recurso especial e recurso ordinário. Revista Trimestral de Jurisprudência dos Estados, São Paulo, v. 151, p. 0931, ago. 1996.

SEABRA FAGUNDES, Miguel. Dos recursos ordinários em matéria civil. Rio de Janeiro: Forense, 1946. 
SHIMURA, Sergio Seiji. Embargos de divergência. WAMBIER, Teresa Arruda Alvim (coord.). Aspectos polêmicos e atuais do recurso especial e do recurso extraordinário. São Paulo: Revista dos Tribunais, 1998.

SICA, Heitor Vitor Mendonça. Recurso intempestivo por prematuridade?. NERY JR., Nelson; WAMBIER, Teresa Arruda Alvim (coords.). Aspectos polêmicos e atuais dos recursos cíveis e assuntos afins - v. 11. São Paulo: Revista dos Tribunais, 2007.

SIQUEIRA, Cleanto Guimarães. recursos ordinários constitucionais em mandado de segurança: hipóteses de cabimento. Revista Forense, v. 358, p. 33-47, nov.-dez. 2001.

SILVA, Erasmo Barros de Figueiredo. Retorno do recurso ordinário no processo de mandado de segurança. Revista Brasileira de Direito Processual, v. 16, p. 93-96, out.-dez. 1978.

SILVA, Fernanda Tartuce. Vulnerabilidade como critério legítimo de desequilibração no processo civil. Tese de doutorado apresentada à Faculdade de Direito da Universidade de São Paulo, sob a orientação do Prof. Rodolfo de Camargo Mancuso. São Paulo, 2011. p. 384.

SILVA, José Afonso da. Curso de direito constitucional positivo. 34. ed. São Paulo: Malheiros, 2011.

SILVA, Ovídio A. Baptista; GOMES, Fábio Luiz. Teoria geral do processo civil. 5. ed. São Paulo: Revista dos Tribunais, 2010.

SORMANI, Alexandre. Princípio do duplo grau de jurisdição. OLIVEIRA NETO, Olavo de; LOPES, Maria Elizabeth de Castro (orgs.). Princípios processuais civis na Constituição. Rio de Janeiro: Elsevier, 2008.

SOUSA, Sílvio Ernane Moura de, Duplo grau civil de jurisdição facultativo e obrigatório, São Paulo: Pillares, 2010.

SOUZA, Bernardo Pimentel. Dos recursos constitucionais. Brasília: Brasília Jurídica, 2007. 
Introdução aos recursos cíveis e à ação rescisória. 8. ed. São Paulo:

Saraiva, 2011.

TAVARES, André Ramos. Análise do duplo grau de jurisdição como princípio constitucional. Revista de Direito Constitucional e Internacional, São Paulo, n. 30, p. 177186, jan.-mar. 2000.

TEIXEIRA, Guilherme Puchalski. Análise fragmentada do duplo grau, enquanto regra de direito. Revista de Processo, São Paulo, n. 158, p. 337-362, abr. 2008.

TESHEINER, José Maria. Ainda precisamos do mandado de segurança?. Revista Brasileira de Direito Processual, Belo Horizonte, n. 69, p. 01-03, jan. 2010.

THEODORO JÚNIOR, Humberto. Curso de direito processual civil - v. I. 50. ed. Rio de Janeiro: Forense, 2009.

. Curso de direito processual civil - v. III. 41. ed. Rio de Janeiro: Forense, 2009.

. O recurso ordinário em mandado de segurança. Revista Jurídica, n. 183, p. 05-15, jan. 1993.

TOSTA, Jorge. Do reexame necessário. São Paulo: Revista dos Tribunais, 2005.

VAZ, Paulo Afonso Brum. Breves considerações acerca do novo $§ 3 .^{\circ}$ do art. 515 do CPC. Revista de Processo, São Paulo, n. 134, p. 88-96, abr. 2006.

VINCENT, Jean. Procédure civile. 17. ed. Paris: Dalloz, 1974.

WAMBIER, Luiz Rodrigues. Teoria geral dos recursos. Revista de Processo, São Paulo, n. 164, p. 333-341, out. 2008.

WAMBIER, Teresa Arruda Alvim. Recurso especial, recurso extraordinário e ação rescisória. 2. ed. São Paulo: Revista dos Tribunais, 2008.

WELSCH, Gisele Mazzoni. O reexame necessário e a efetividade da tutela jurisdicional. Porto Alegre: Livraria do Advogado, 2010. 
ZANZUCCHI, Marco Tullio. Diritto processuale civile - v. 2. 5. ed. Milano: Giuffrè, 1962. 